Prepared in cooperation with the Osage Nation

\title{
Precipitation Runoff Modeling System (PRMS) as Part of an Integrated Hydrologic Model for the Osage Nation, Northeastern Oklahoma, 1915-2014
}

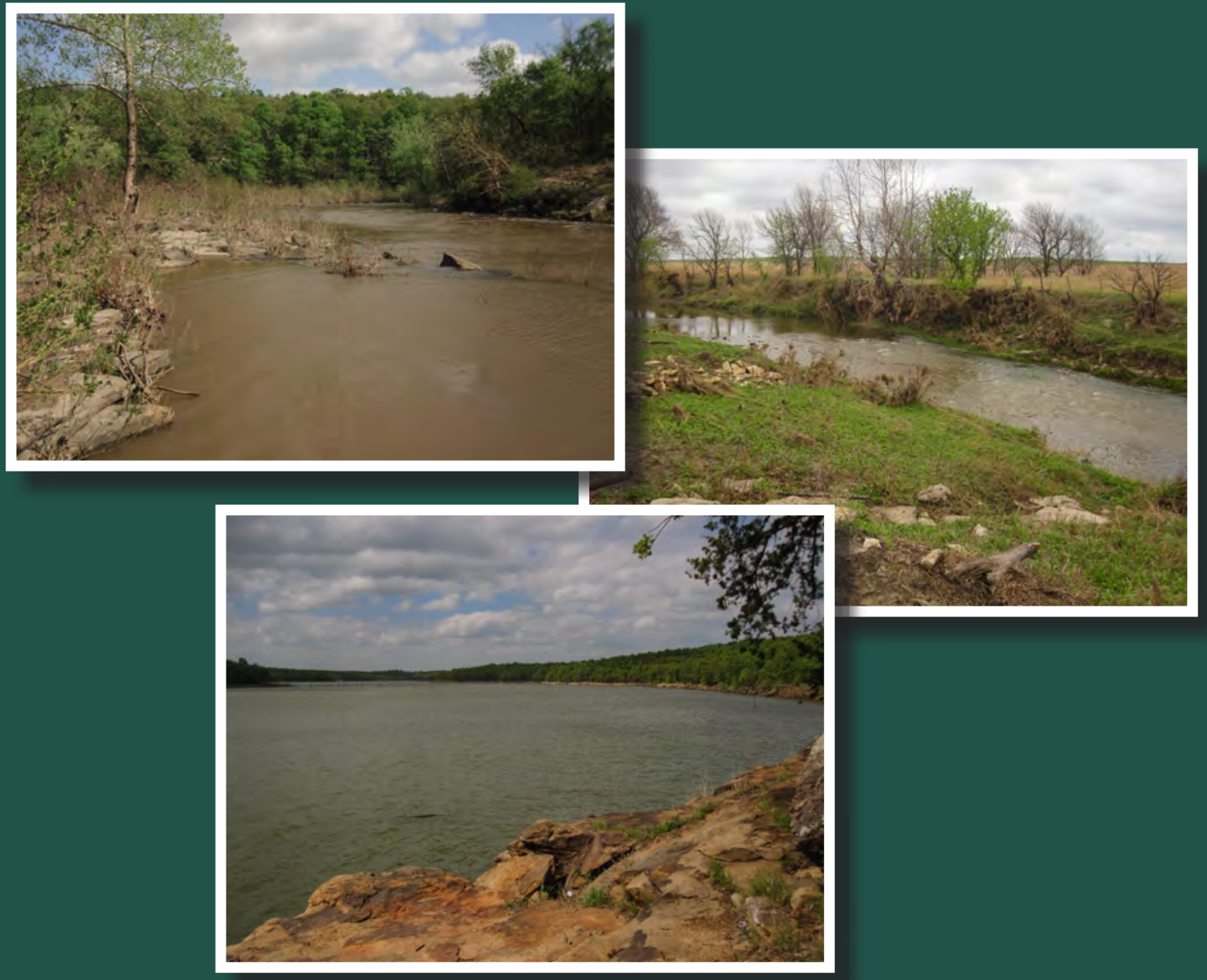

Scientific Investigations Report 2019-5030 
Cover: Top Left. Sand Creek, downstream view towards the east, Osage Hills State Park, approximately half-way between Pawhuska and Bartlesville, Eastern Osage Nation; photograph taken by Joseph A. Hevesi.

Middle Right. Elm Creek tributary of upper Salt Creek, upstream view towards the northeast from county road 4600 bridge, northwest Osage Nation; photograph taken by Joseph A. Hevesi.

Bottom Left. Skiatook Reservoir, view towards the north from shoreline on the east side of highway 20 bridge, southern 0sage Nation; photograph taken by Joseph A. Hevesi. 


\section{Precipitation Runoff Modeling System (PRMS) as Part of an Integrated Hydrologic Model for the Osage Nation, Northeastern Oklahoma, 1915-2014}

By Joseph A. Hevesi, Randall T. Hanson, and Jason R. Masoner

Prepared in cooperation with the Osage Nation

Scientific Investigations Report 2019-5030 


\title{
U.S. Department of the Interior DAVID BERNHARDT, Secretary
}

\author{
U.S. Geological Survey \\ James F. Reilly II, Director
}

U.S. Geological Survey, Reston, Virginia: 2019

For more information on the USGS - the Federal source for science about the Earth, its natural and living resources, natural hazards, and the environment-visit https://www.usgs.gov or call 1-888-ASK-USGS.

For an overview of USGS information products, including maps, imagery, and publications, visit https://store.usgs.gov.

Any use of trade, firm, or product names is for descriptive purposes only and does not imply endorsement by the U.S. Government.

Although this information product, for the most part, is in the public domain, it also may contain copyrighted materials as noted in the text. Permission to reproduce copyrighted items must be secured from the copyright owner.

Suggested citation:

Hevesi, J.A., Hanson, R.T., and Masoner, J.R., 2019, Precipitation runoff modeling system (PRMS) as part of an integrated hydrologic model for the Osage Nation, northeastern Oklahoma, 1915-2014: U.S. Geological Survey Scientific Investigations Report 2019-5030, 142 p., https://doi.org/10.3133/sir20195030.

Associated data for this publication:

National Water Information System: Web Interface, http://doi.org/10.5066/F7P55KJN. 


\section{Acknowledgments}

The authors acknowledge support from the Osage Nation, Gary McManus and Taylor McCorkle with the Oklahoma Climatological Society, and Chris Neel with the Oklahoma Water

Resources Board.

The authors also acknowledge Robert S. Regan with the U.S. Geological Survey (USGS) Precipitation Runoff Modeling System (PRMS) development team who provided support with PRMS code modifications and testing. Carol Becker with the USGS Oklahoma Water Science Center provided support with the geographic information system (GIS) and water-budget data. Jerry Tran, Robin L. Miller, and Kim Engelking with the USGS Sacramento Publishing Service Center helped develop and finalize illustrations and tables, performed editorial reviews, and developed the final layout for the report. Technical reviews were provided by Wesley Kitlasten with the USGS Nevada Water Science Center, Steve Markstrom with the USGS National Research Program, and Jason Lewis, surface-water specialist with the USGS Oklahoma Water Science Center. 


\section{Contents}

Executive Summary ................................................................................................................

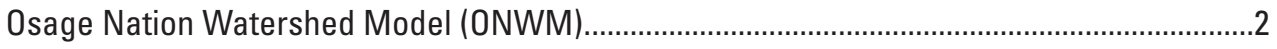

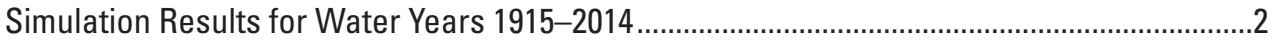

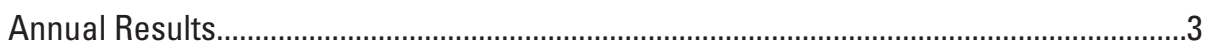

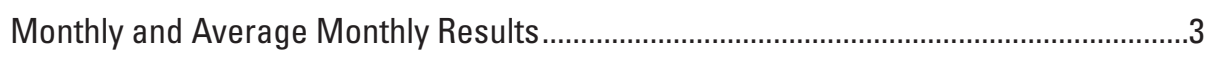

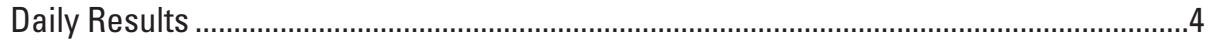

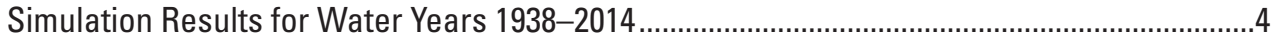

Model Limitations.

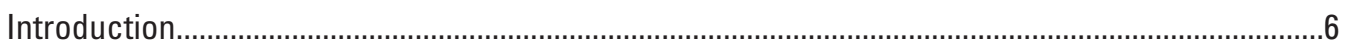

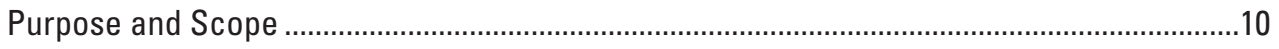

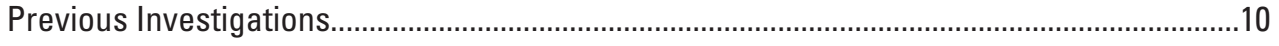

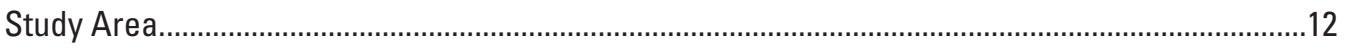

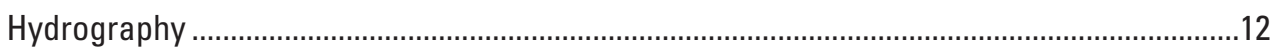

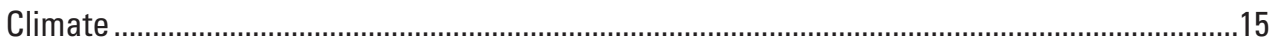

Precipitation

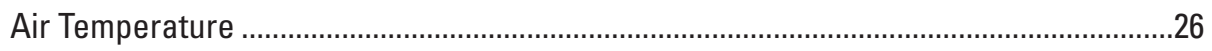

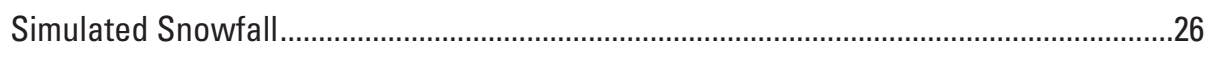

Physiography and Land Cover ........................................................................................

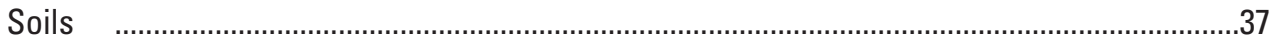

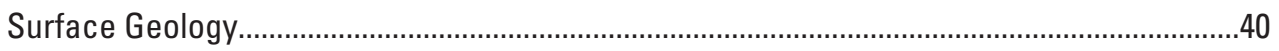

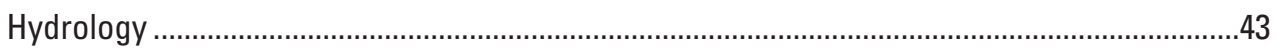

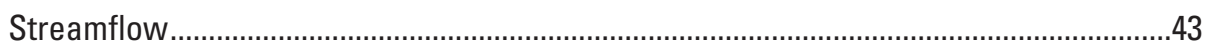

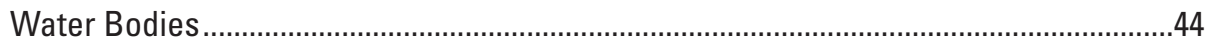

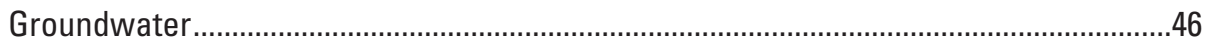

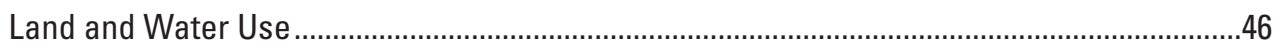

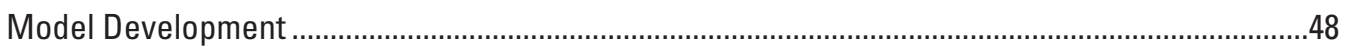

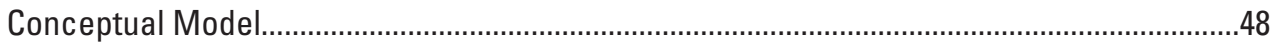

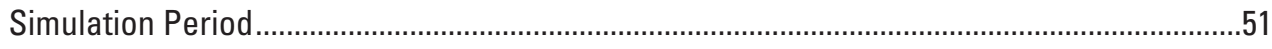

Model Layout and Discretization ...............................................................................

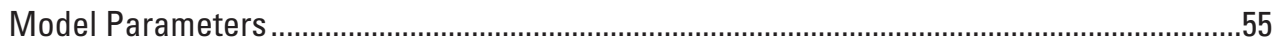

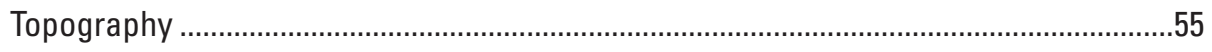

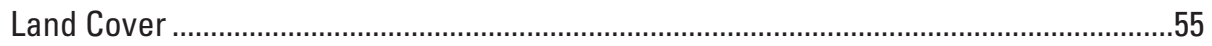

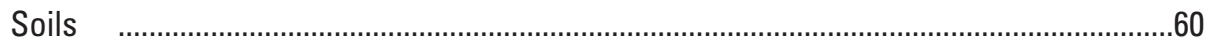

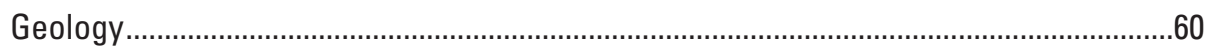

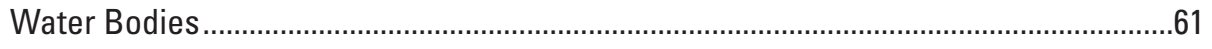

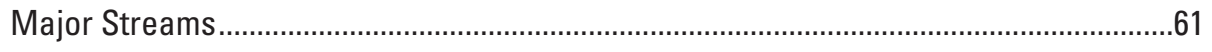

Climate Inputs..............................................................................................................

Daily Precipitation and Air Temperature......................................................................62

Mean Monthly Precipitation and Air Temperature …………………………………...62

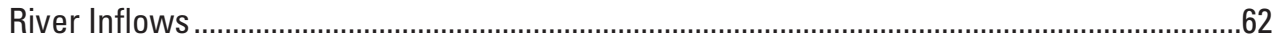




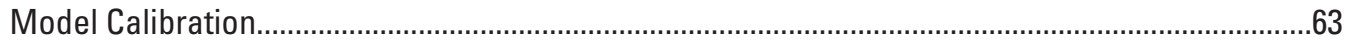

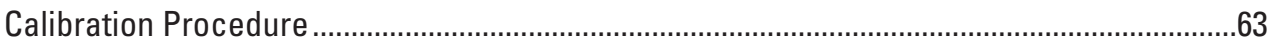

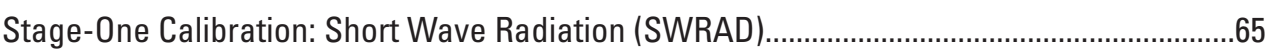

Stage-Two Calibration: Potential Evapotranspiration (PET) ....................................................

Stage-Three Calibration: Soil Moisture .................................................................................77

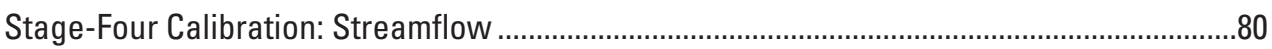

Model Sensitivity using Simulated Streamflow...............................................................83

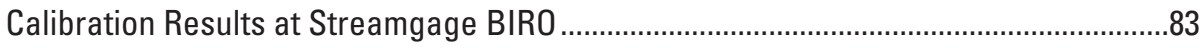

Calibration Results at Streamgage BLAP ....................................................................

Calibration Results at Streamgage CANO ……………................................................90

Calibration Results at Streamgages AKRK and ARKT …….........................................92

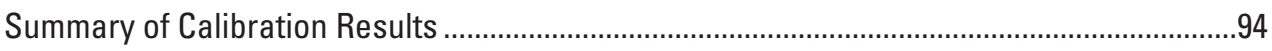

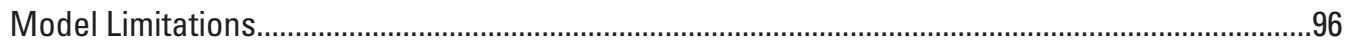

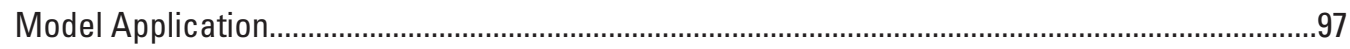

Simulated Water Budget, Water Years 1915-2014 ……...................................................98

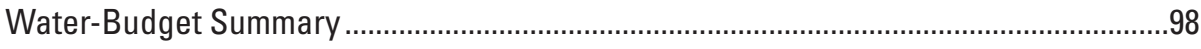

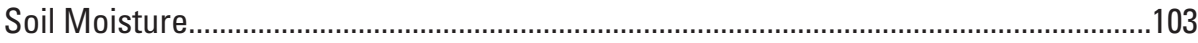

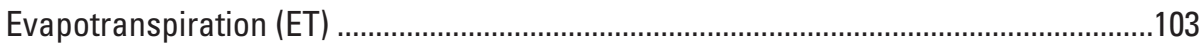

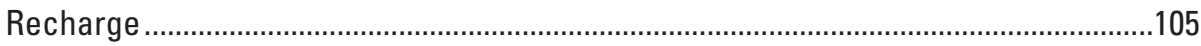

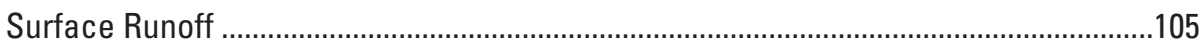

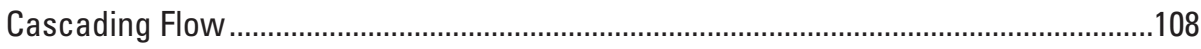

Simulated Streamflow, Water Years 1915-2014.................................................................111

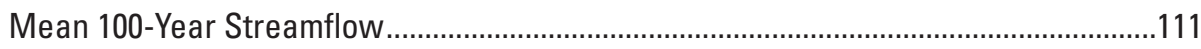

Maximum Daily Streamflow................................................................................111

Minimum Daily Streamflow...................................................................................116

Simulated Streamflow, Water Years 1938-2014 ...............................................................119

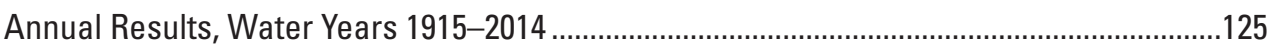

Monthly Results, Water Years 1915-2014 ……………...................................................129

Monthly Recharge and Streamflow........................................................................129

Mean Monthly Water Budgets .................................................................................131

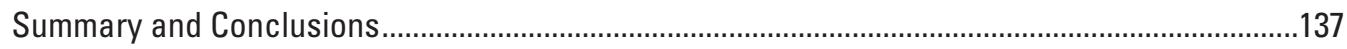

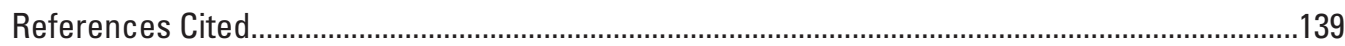




\section{Figures}

1. Maps showing the Osage Nation watershed model and the Osage Nation integrated hydrologic model areas, Oklahoma and Kansas.

2. Map showing surface-water subbasins, inflows, outflows, and streamgages included in the Osage Nation watershed model, Oklahoma and Kansas

3. Map showing spatially distributed mean annual precipitation estimated for water years 1915-2014 for the Osage Nation watershed model, Oklahoma and Kansas..........17

4. Graphs showing annual precipitation for water years 1915-2014 in the 0sage Nation watershed model area, Oklahoma and Kansas.

5. Graphs showing mean monthly precipitation, maximum and minimum air temperatures, and potential evapotranspiration, water years 1915-2014, averaged for the area of the Osage Nation watershed model, Oklahoma and Kansas

6. Map showing spatial distribution of mean maximum daily air temperature estimated for water years 1915-2014 for the Osage Nation Watershed Model area, Oklahoma and Kansas

7. Map showing spatially distributed mean minimum daily air temperature estimated for water years 1915-2014 for the Osage Nation watershed model area, Oklahoma and Kansas

8. Graphs showing air temperature for water years 1915-2014 in the Osage Nation watershed model area, Oklahoma and Kansas.

9. Map showing spatially distributed mean annual snowfall estimated for water years 1915-2014 for the Osage Nation watershed model area, Oklahoma and Kansas

10. Map showing mean land-surface slope in the Osage Nation watershed model area, Oklahoma and Kansas.

11. Map showing land-cover classifications in the Osage Nation watershed model area, Oklahoma and Kansas

12. Map showing percentage of impervious land cover in the Osage Nation watershed model area, Oklahoma and Kansas.

13. Map showing percentage of forest-canopy cover in the Osage Nation watershed model area, Oklahoma and Kansas

14. Map showing vertical soil hydraulic conductivity, estimated using the the Soil Survey Geographic database, in the Osage Nation watershed model area, Oklahoma and Kansas

15. Map showing soil water content at field capacity, calculated using the SoilDataViewer and the Soil Survey Geographic database, in the Osage Nation watershed model area, Oklahoma and Kansas.

16. Map showing surface geology, in the Osage Nation watershed model area, Oklahoma and Kansas

17. Map showing calculated percentage of land covered by water, Osage Nation Watershed Model area, Oklahoma and Kansas

18. Diagrams showing conceptual model used for the Osage Nation Watershed Model, Oklahoma and Kansas.

19. Map showing model layout showing hydrologic response units used in the Osage Nation Watershed Model, Oklahoma and Kansas

20. Map showing model layout showing major stream channels defined as stream segments in the Osage Nation Watershed Model, Oklahoma and Kansas 
21. Map showing Oklahoma Climatological Survey Mesonet stations and U.S. Geological Survey streamgages and associated subdrainages used for model calibration, Osage Nation watershed model, Oklahoma and Kansas...

22. Graph showing water years having streamflow records for 22 U.S. Geological Survey streamgages used for model calibration, Osage Nation watershed model, Oklahoma and Kansas

23. Graphs showing comparison of simulated short-wave radiation at Mesonet station BIXB, using the Osage Nation watershed model, Oklahoma and Kansas, with observed values

24. Graphs showing comparison between simulated and observed short-wave radiation at 14 Oklahoma Climatological Survey Mesonet stations for the Osage Nation watershed model, Oklahoma and Kansas

25. Graphs showing comparison between simulated and observed potential evapotranspiration at station COPA using the Osage Nation watershed model, Oklahoma and Kansas

26. Graphs showing comparison of simulated and observed potential evapotranspiration at 14 Oklahoma Climatological Survey Mesonet stations, the Osage Nation Watershed Model, Oklahoma and Kansas....

27. Map showing simulated mean annual potential evapotranspiration for water years 1915-2014 using the Osage Nation watershed model, Oklahoma and Kansas.....75

28. Graphs showing simulated annual potential evapotranspiration for water years 1915-2014 using the Osage Nation watershed model, Oklahoma and Kansas..

29. Graphs showing comparison between simulated to observed soil-water-content fraction (soil moisture) at station WYNO using the Osage Nation watershed model, Oklahoma and Kansas

30. Graphs showing comparison of simulated to observed soil-water-content fraction at 13 Oklahoma Climatological Survey Mesonet stations, the Osage Nation Watershed Model, Oklahoma and Kansas

31. Graphs showing sensitivity results for streamflow using the Osage Nation Watershed Model, Oklahoma and Kansas.

32. Graphs showing comparison between simulated streamflow using the Osage Nation watershed model and observed streamflow at streamgage BIR0, Oklahoma and Kansas

33. Graphs showing comparison between simulated streamflow using the Osage Nation watershed model and observed streamflow at streamgage BIRO, Oklahoma and Kansas

34. Graphs showing comparison between simulated streamflow using the Osage Nation watershed model and observed streamflow at streamgage BLAP, Oklahoma and Kansas

35. Graphs showing comparison between simulated streamflow using the Osage Nation watershed model and observed streamflow at streamgage BLAP, Oklahoma and Kansas

36. Graphs showing comparison between simulated streamflow using the Osage Nation watershed model and observed streamflow at streamgage CANO, Oklahoma and Kansas

37. Graphs showing comparison between simulated streamflow using the Osage Nation watershed model and observed streamflow at streamgage CANO, Oklahoma and Kansas 
38. Graphs showing comparison between simulated annual streamflow using the Osage Nation watershed model and the calculated differences in observed annual mean streamflow at streamgage ARKR and streamgage ARKT, Oklahoma and Kansas

39. Graphs showing simulated and observed mean period-of-calibration streamflow at 22 streamgages used to calibrate the Osage Nation watershed model, Oklahoma and Kansas

40. Piecharts showing simulated outflows as a percentage of precipitation for water years 1915-2014 using the Osage Nation watershed model, Oklahoma and Kansas

41. Map showing simulated 100 -year mean soil moisture using the Osage Nation watershed model, water years 1915-2014, Oklahoma and Kansas..... 104

42. Map showing simulated 100 -year mean annual evapotranspiration using the Osage Nation watershed model, water years 1915-2014, Oklahoma and Kansas 106

43. Map showing simulated 100 -year mean annual recharge using the 0sage Nation watershed model, water years 1915-2014, Oklahoma and Kansas...

44. Map showing simulated 100-year mean annual surface runoff using the Osage Nation watershed model, water years 1915-2014, Oklahoma and Kansas

45. Map showing simulated 100 -year mean annual cascading flow using the 0 sage Nation watershed model, water years 1915-2014, Oklahoma and Kansas

46. Map showing simulated 100 -year mean streamflow using the Osage Nation watershed model, boundary inflows from upstream drainages excluded, water years 1915-2014, Oklahoma and Kansas.....

47. Map showing simulated maximum daily mean streamflow using the 0sage Nation watershed model, boundary inflows excluded, water years 1915-2014, Oklahoma and Kansas

48. Map showing simulated minimum daily mean streamflow using the Osage Nation watershed model, boundary inflows excluded, water years 1915-2014, Oklahoma and Kansas

49. Graph showing simulated mean, maximum, and minimum daily streamflow, boundary inflows excluded, verus contributind drainage areas for stream segments in the Osage Nation watershed model, water years 1915-2014, Oklahoma and Kansas

50. Graphs showing simulated annual results using the Osage Nation watershed model, water years 1915-2014, Oklahoma and Kansas.

51. Graphs showing simulated annual results for water years 1915-2014 for the area of the Osage Nation integrated hydrologic model and selected subbasin areas, the Osage Nation watershed model, Oklahoma and Kansas.

52. Graphs showing simulated monthly recharge for water years 1915-2014 using the Osage Nation watershed model, Oklahoma and Kansas.

53. Graphs showing simulated monthly streamflow for water years 1915-2014 using the Osage Nation watershed model, Oklahoma and Kansas.

54. Graphs showing mean monthly simulation results using the Osage Nation watershed model, Oklahoma and Kansas

55. Graphs showing mean monthly water contents for storage components, the Osage Nation watershed model, Oklahoma and Kansas. 


\section{Tables}

1A. Surface-water subbasin areas used in the Osage Nation watershed model, Oklahoma and Kansas...

1B. Surface-water subbasin inflows and outflows used in the Osage Nation watershed model, Oklahoma and Kansas

2. Streamgages with daily mean discharge records used in the development and calibration of the Osage Nation watershed model, Oklahoma and Kansas...

3. Climate stations with records used to develop daily precipitation and airtemperature inputs for the Osage Nation watershed model, Oklahoma and Kansas .

4. Land-cover areas for the Osage Nation watershed model, Oklahoma and Kansas.......34

5. Surface geology of the Osage Nation watershed model area, Oklahoma and Kansas ....

6. Major water bodies in the Osage Nation watershed model area, Oklahoma and Kansas .

7. Precipitation Runoff Modeling System parameters used in the Osage Nation watershed model, Oklahoma and Kansas

8. Goodness-of-fit results using simulated and observed monthly short-wave radiation, Osage Nation watershed model, Oklahoma and Kansas...

9. Goodness-of-fit results using simulated and observed monthly potential evapotranspiration, Osage Nation watershed model, Oklahoma and Kansas.

10. Goodness-of-fit results using simulated and observed soil-water-content fraction of the root zone, Osage Nation watershed model, Oklahoma and Kansas.

11A. Goodness-of-fit results using simulated and observed daily mean streamflow, Osage Nation watershed model, Oklahoma and Kansas.

11B. Goodness-of-fit results using observed and simulated monthly mean discharge, Osage Nation watershed model, Oklahoma and Kansas.

11C. Goodness-of-fit results using simulated and observed annual mean discharge, Osage Nation watershed model, Oklahoma and Kansas.

12A. Simulated 100-year mean water budget, water years 1915-2014, basin-wide mean water-equivalent depth, Osage Nation watershed model, Oklahoma and Kansas

12B. Simulated 100-year average water budget, water years 1915-2014, basin-wide average water volumes, Osage Nation watershed model, Oklahoma and Kansas ......100

13. Simulated streamflow for water years 1915-2014, boundary inflows from upstream drainages excluded, using the Osage Nation watershed model, Oklahoma and Kansas

14A. Simulated streamflow for water years 1938-2014, boundary inflows from upstream drainages included, Osage Nation watershed model mean, Oklahoma and Kansas

14B. Simulated streamflow for water years 1938-2014, boundary inflows from upstream drainages excluded, Osage Nation watershed model, Oklahoma and Kansas .

14C. Simulated difference in streamflow for water years 1938-2014, results for simulations with inflows from upstream drainages included minus results for simulations with inflows excluded, Osage Nation watershed model, Oklahoma and Kansas 


\section{Conversion Factors}

U.S. customary units to International System of Units

\begin{tabular}{|c|c|c|}
\hline Multiply & By & To obtain \\
\hline \multicolumn{3}{|c|}{ Length } \\
\hline inch (in.) & 2.54 & centimeter $(\mathrm{cm})$ \\
\hline inch (in.) & 25.4 & millimeter $(\mathrm{mm})$ \\
\hline foot $(\mathrm{ft})$ & 0.3048 & meter $(\mathrm{m})$ \\
\hline mile (mi) & 1.609 & kilometer $(\mathrm{km})$ \\
\hline \multicolumn{3}{|c|}{ Area } \\
\hline acre & 4,047 & square meter $\left(\mathrm{m}^{2}\right)$ \\
\hline acre & 0.4047 & hectare (ha) \\
\hline acre & 0.004047 & square kilometer $\left(\mathrm{km}^{2}\right)$ \\
\hline square foot $\left(\mathrm{ft}^{2}\right)$ & 929.0 & square centimeter $\left(\mathrm{cm}^{2}\right)$ \\
\hline square foot $\left(\mathrm{ft}^{2}\right)$ & 0.09290 & square meter $\left(\mathrm{m}^{2}\right)$ \\
\hline square mile $\left(\mathrm{mi}^{2}\right)$ & 259.0 & hectare (ha) \\
\hline square mile $\left(\mathrm{mi}^{2}\right)$ & 2.590 & square kilometer $\left(\mathrm{km}^{2}\right)$ \\
\hline \multicolumn{3}{|c|}{ Volume } \\
\hline million gallons (Mgal) & 3,785 & cubic meter $\left(\mathrm{m}^{3}\right)$ \\
\hline cubic inch $\left(\mathrm{in}^{3}\right)$ & 16.39 & cubic centimeter $\left(\mathrm{cm}^{3}\right)$ \\
\hline cubic foot $\left(\mathrm{ft}^{3}\right)$ & 28.32 & cubic decimeter $\left(\mathrm{dm}^{3}\right)$ \\
\hline cubic foot $\left(\mathrm{ft}^{3}\right)$ & 0.02832 & cubic meter $\left(\mathrm{m}^{3}\right)$ \\
\hline cubic yard $\left(\mathrm{yd}^{3}\right)$ & 0.7646 & cubic meter $\left(\mathrm{m}^{3}\right)$ \\
\hline acre-foot (acre-ft) & 1,233 & cubic meter $\left(\mathrm{m}^{3}\right)$ \\
\hline \multicolumn{3}{|c|}{ Flow rate } \\
\hline acre-foot per year (acre-ft/yr) & 1,233 & cubic meter per year $\left(\mathrm{m}^{3} / \mathrm{yr}\right)$ \\
\hline cubic foot per second $\left(\mathrm{ft}^{3} / \mathrm{s}\right)$ & 0.02832 & cubic meter per second $\left(\mathrm{m}^{3} / \mathrm{s}\right)$ \\
\hline million gallons per day (Mgal/d) & 0.04381 & cubic meter per second $\left(\mathrm{m}^{3} / \mathrm{s}\right)$ \\
\hline inch per hour (in/h) & 0.0254 & meter per hour $(\mathrm{m} / \mathrm{h})$ \\
\hline inch per day (in/d) & 0.0254 & meter per day $(\mathrm{m} / \mathrm{d})$ \\
\hline inch per year (in/yr) & 25.4 & millimeter per year $(\mathrm{mm} / \mathrm{yr})$ \\
\hline \multicolumn{3}{|c|}{ Pressure } \\
\hline atmosphere, standard (atm) & 101.3 & kilopascal $(\mathrm{kPa})$ \\
\hline \multicolumn{3}{|c|}{ Solar Radiation } \\
\hline langley (Ly) & 0.153613 & British thermal unit per square foot (BTU/ $\left.\mathrm{ft}^{2-\mathrm{hr}}\right)$ \\
\hline
\end{tabular}

Temperature in degrees Fahrenheit $\left({ }^{\circ} \mathrm{F}\right)$ may be converted to degrees Celsius $\left({ }^{\circ} \mathrm{C}\right)$ as follows: ${ }^{\circ} \mathrm{C}=\left({ }^{\circ} \mathrm{F}-32\right) / 1.8$.

\section{Datum}

Horizontal coordinate information is referenced to, North American Datum of 1983 (NAD 83).

Vertical coordinate information is referenced to the North American Vertical Datum of 1988 (NAVD 88). 


\section{Supplemental Information}

A water year is the 12-month period from 0ctober 1 through September 30 and is designated by the calendar year in which it ends.

\section{Acronyms and Abbreviations}

$\begin{array}{ll}\text { AMO } & \text { Atlantic Multidecadal Oscillation } \\ \text { D-8 } & \text { eight-direction routing } \\ \text { DEM } & \text { digital elevation model } \\ \text { ENSO } & \text { El Nino-Southern Oscillation } \\ \text { ET } & \text { evapotranspiration } \\ \text { ET } & \text { reference evapotranspiration } \\ \text { GIS } & \text { geographic information system } \\ \text { GSFLOW } & \text { Groundwater and Surface-water Flow model } \\ \text { HRU } & \text { hydrologic response unit } \\ \text { HSPF } & \text { Hydrologic Simulation Program-FORTRAN } \\ \text { HUC } & \text { hydrologic unit code } \\ \text { LOWESS } & \text { locally weighted scatterplot smoothing } \\ \text { MOVE1 } & \text { maintenance of variance estimation } \\ \text { MUID } & \text { map unit identifier } \\ \text { NAMS-PE } & \text { North American Monsoon-Pineapple Express } \\ \text { NED } & \text { National Elevation Dataset } \\ \text { NHD } & \text { National Hydrography Dataset } \\ \text { NLCD } & \text { National Land Cover Data } \\ \text { NSME } & \text { Nash-Sutcliffe model efficiency } \\ \text { OCS } & \text { Oklahoma Climatological Survey } \\ \text { ONIHM } & \text { Osage Nation Integrated Hydrologic Model } \\ \text { ONWM } & \text { Osage Nation Watershed Model } \\ \text { PAEE } & \text { percent average estimation error } \\ \text { PDO } & \text { Pacific Decadal Oscillation } \\ \text { PEST } & \text { Parameter Estimation } \\ \text { PET } & \text { potential evapotranspiration } \\ \text { PRISM } & \text { Parameter-elevation Regressions on Independent Slopes Model } \\ \text { PRMS } & \text { Precipitation-Runoff Modeling System } \\ \text { R2 } & \text { R-squared } \\ \text { SSURGO } & \text { Soil Survey Geographic Database } \\ \text { SWRAD } & \text { short-wave radiation } \\ \text { USGS } & \text { U.S. Geological Survey } \\ \text { WCFC } & \text { water content at field capacity } \\ \text { PET } & \end{array}$




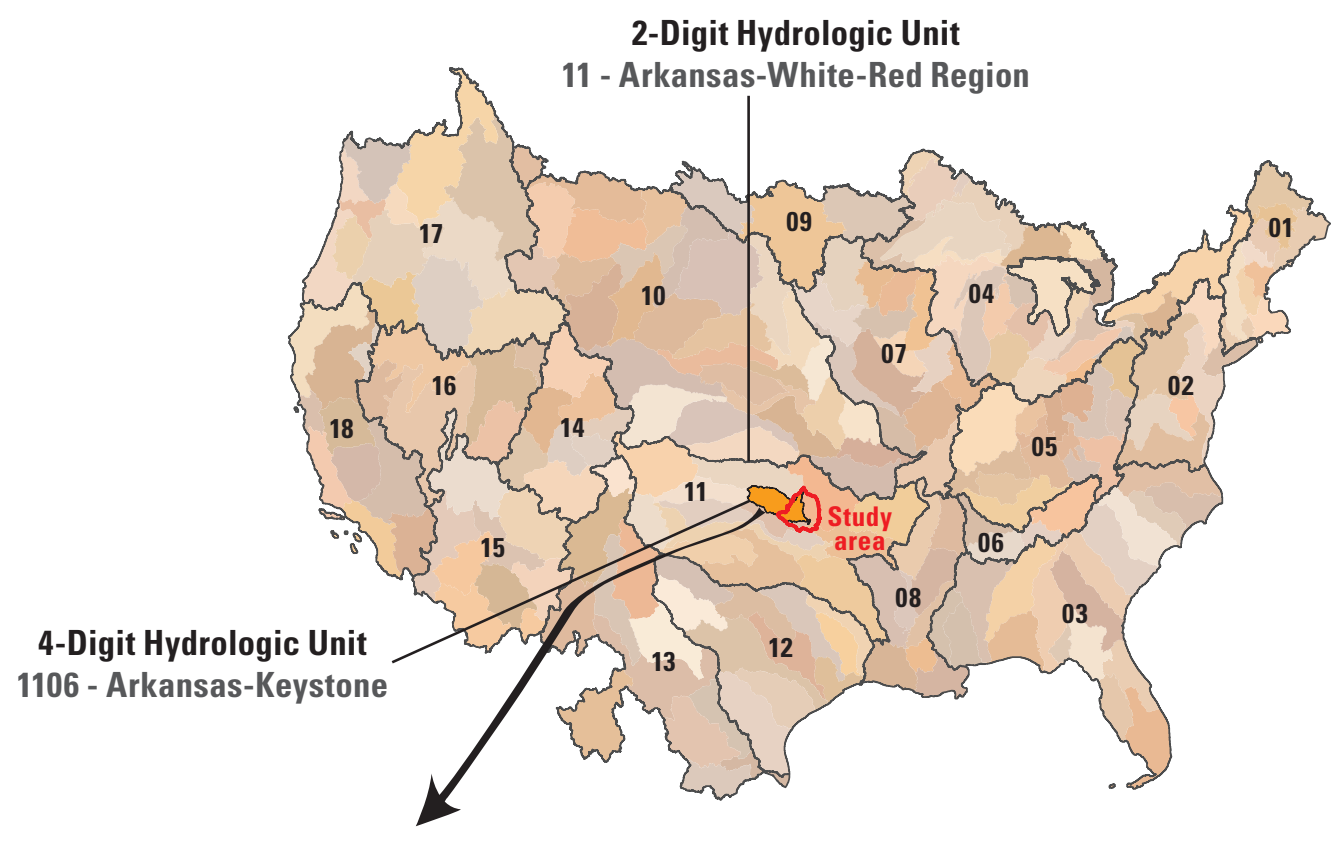

6-Digit Hydrologic Unit

110600 - Arkansas-Keystone

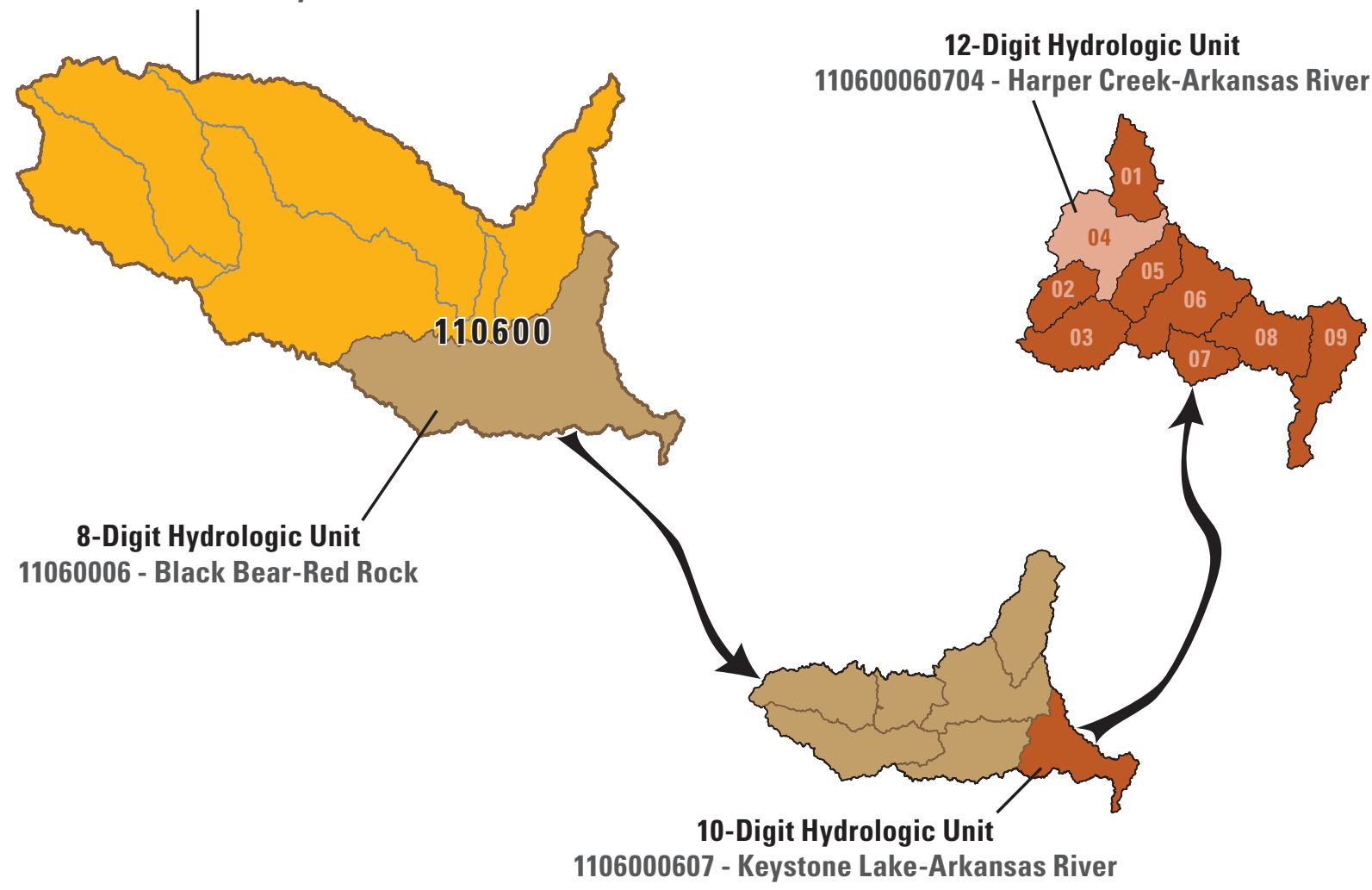

Illustration showing hierarchy of regional and subregional hydrologic units and associated 2-, 4-, 6-, 8-, 10, and 12-digit hydrologic unit codes (HUCs) for the region containing the study area defined by the Osage Nation watershed model. 


\title{
Precipitation Runoff Modeling System (PRMS) as Part of an Integrated Hydrologic Model for the Osage Nation, Northeastern Oklahoma, 1915-2014
}

\author{
By Joseph A. Hevesi, Randall T. Hanson, and Jason R. Masoner
}

\section{Executive Summary}

The Osage Nation lacks a comprehensive tribal water plan to describe the quality and quantity of water resources in the Osage Nation, a 2,304-square-mile $\left(\mathrm{mi}^{2}\right)$ area of rolling pastures, tallgrass prairie, and mixed woodlands in northeastern Oklahoma. A tribal water plan can be used to help manage the sustainable development of surface and groundwater resources, thereby helping to provide a better future for the Osage Nation and their neighbors, while preserving water resources for the benefit of the surrounding environment and future generations. To help meet these goals and contribute to increased knowledge of the quantity and quality of water resources and the hydrologic processes and factors affecting those resources, the U.S. Geological Survey (USGS) in cooperation with the Osage Nation began studies to evaluate the surface-water and groundwater resources of the Osage Nation. An important component of these studies is the development and application of numerical models to improve quantification and understanding of the hydrologic system. These models are needed to estimate and quantify the effects of historical and potential future water resource development for the Osage Nation.

This report describes the development and application of a precipitation-runoff model, the Osage Nation watershed model (ONWM). The ONWM is needed as a component of the Osage Nation integrated hydrologic model (ONIHM). At the time of this study, the ONIHM was being developed using the USGS computer software MODFLOW-One Water Hydrologic Flow Model (MODFLOW-OWHM). The intended use of the ONIHM is to simulate all surface-water and groundwater components of the hydrologic system for a 2,905- $\mathrm{mi}^{2}$ study area centered on the Osage Nation. The
ONWM was developed using the USGS Precipitation Runoff Modeling System, version 4 (PRMS-IV) computer software, also referred to as PRMS in this report, for an 8,343- $\mathrm{mi}^{2}$ study area in northeastern Oklahoma and southeastern Kansas, centered on and including the areas of the Osage Nation and the ONIHM. The ONWM is to be used as part of the ONIHM to provide a direct coupling with spatially and temporally varying daily climate conditions affecting the ONIHM study area. As an integral part of the ONIHM, the ONWM (1) simulates the inflow boundary conditions from tributary basins in the region outside and surrounding the ONIHM area; (2) provides estimates of spatially and temporally distributed precipitation, air temperature, potential evapotranspiration (PET), actual evapotranspiration (ET), soil moisture, recharge, and streamflow in the ONIHM area; and (3) provides a preliminary water budget for the ONIHM area and the surrounding region, including tributary drainage basins outside of and next to the ONIHM.

The specific objectives of this study were to use the ONWM to (1) provide a systematic inventory of the historical distribution of water inflows from precipitation (rain or snow) falling on the land surface and flowing through the surface-water network, (2) provide a historical context of the variability and spatial and temporal distribution of these waters, and (3) provide estimates of water inflows and potential observations to the ONIHM. The application of the ONWM as a component of the ONIHM is needed for planned simulations using the ONIHM to improve the understanding of the hydrologic system and to develop a fully comprehensive water budget, including the use and movement of water across the landscape, in the surface-water network, and in groundwater aquifers under historical and potential future conditions. 


\section{Osage Nation Watershed Model (ONWM)}

The ONWM was developed using PRMS and performs a continuous daily simulation of the hydrologic system with an emphasis on hydrologic processes of the land surface (including vegetation cover and impervious and pervious areas) and the shallow subsurface defined by the upper soil layer and the root zone. PRMS simulates PET, ET, snow hydrology, overland-flow processes (surface runoff), interflow processes in the soil zone, recharge, groundwater losses, groundwater discharge (base flow), and streamflow. PRMS represents the hydrologic system as a segmented and partitioned network of water storage and flow processing components consisting of hydrologic response units (HRUs) and groundwater reservoirs that are linked in a connected network of cascading flow paths used to simulate surface runoff, interflow, and base flow as inflows to streams. Streamflow is simulated as the accumulated inflows to stream channels represented as a drainage network of linked stream segments. The storage components represented in the linked network of HRUs, groundwater reservoirs, and stream segments include interception, retention, depression, snowpack, soil-zone, and groundwater-storage components.

The 8,343- $\mathrm{mi}^{2}$ area of the ONWM includes all or part of the areas of three main surface-water drainages: (1) the 2,094-mi ${ }^{2}$ Caney River surface-water drainage in the northeastern parts of the Osage Nation and the ONIHM area, (2) the 1,137- $\mathrm{mi}^{2}$ Bird Creek surface-water drainage in the central and southeastern parts of the Osage Nation and the ONIHM area, and (3) a 5,112- $\mathrm{mi}^{2}$ section of the Arkansas River surface-water drainage in the western parts of the Osage Nation and the ONIHM, referred to in this study as the Arkansas River surface-water subdrainage. The ONWM was discretized using a grid-based layout with an equidimensional grid spacing of $1,312.3$ by $1,312.3$ feet that defined HRUs and their connected groundwater reservoirs as equal-area, 39.54-acre cells. With this discretization, the ONWM domain contained 135,044 HRUs and groundwater reservoirs that were connected by cascading-flow paths to 7,389 linked stream segments representing the larger stream channels in the ONWM area.

The ONWM used spatially interpolated daily climate inputs for precipitation and maximum and minimum air temperatures for a 105 -year period starting with water year 1910 and ending with water year 2014; a water year is the 12-month period October 1 through September 30 designated by the calendar year in which it ends. The daily climate inputs were developed using records of daily precipitation and maximum and minimum daily air temperatures from 203 climate stations and a modified inverse-distance-squared interpolation method that used estimates of mean monthly precipitation and mean monthly maximum and minimum air temperatures from the Parameter-elevation Regressions on Independent Slopes Model (PRISM). The climate inputs were used by PRMS to simulate daily short-wave radiation (SWRAD) and daily PET. The daily time step provided a detailed accounting of the root-zone water budget and allowed for model calibration by comparing simulation results to observations consisting of available records of SWRAD, PET, and soil moisture at 14 Oklahoma Climatological Survey Mesonet field stations and to observations consisting of available records of daily streamflow at 22 USGS streamgages. Geographic information system (GIS) data were used to develop initial estimates for model parameters, and subsequently, a set of critical parameters were adjusted during model calibration. Results using the Parameter Estimation (PEST) code and observed streamflows indicated the greatest model sensitivity, in terms of simulated streamflow, to PRMS parameters controlling the magnitude of overland flow (carea_max, smidx_coef, smidx_exp), parameters controlling the rates of interflow (slowcoef_lin, slowcoef_sq), parameters defining the storage of water in the root zone available for ET (soil_moist_max, soil_rechr_max), and parameters controlling the rates of recharge and groundwater discharge ( $s s r 2 g w$ rate, gwflow_coef). Calibration results using monthly time series for simulated compared with recorded SWRAD and PET were excellent at all sites, whereas calibration results using monthly time series for simulated and recorded soil moisture were fair, but acceptable. Calibration results for simulated and recorded streamflow were fair to acceptable using daily time series, and good to excellent using monthly and annual time series.

\section{Simulation Results for Water Years 1915-2014}

The ONWM was used to simulate the daily water budget for a continuous 100-year period that began October 1, 1914, and ended September 30, 2014 (water years 19152014). The simulation was started on October 1, 1909, to allow for a 5-year model initialization period prior to the start of the 100-year target period. Results indicated that ET was the largest outflow from the ONWM, averaging 27.9 inches per year (in/yr), or about 12.4 million acre feet per year (acre-ft/yr). Simulated ET accounted for 77 percent of the precipitation inflow of $36.1 \mathrm{in} / \mathrm{yr}$ (about 16.1 million acre-ft/yr). The simulated mean annual PET of $51.7 \mathrm{in} / \mathrm{yr}$ (about 23.0 million acre-ft/yr) was greater than mean annual precipitation; however, during a given storm period, daily precipitation often greatly exceeded daily PET, resulting in excess water in the root zone that contributed to surface runoff, interflow, and recharge. Transpiration from the soil zone was the largest component of total ET, averaging $25.9 \mathrm{in} / \mathrm{yr}$ (about 11.5 million acre-ft/yr), about 72 percent of precipitation. Streamflow, expressed as an equivalent water depth discharged from the ONWM area, was the second largest outflow from the ONWM, averaging $7.1 \mathrm{in} / \mathrm{yr}$ (3.1 million acre-ft/yr), about 20 percent of precipitation. This simulated streamflow was equal to a mean streamflow of 4,331 cubic feet per second $\left(\mathrm{ft}^{3} / \mathrm{s}\right)$ discharging from the ONWM area. Recharge was the third largest component of the ONWM simulated water budget, averaging $4.2 \mathrm{in} / \mathrm{yr}$ (1.9 million acre-ft/yr) or about 12 percent of precipitation. 
The 100-year simulation results for the ONIHM area were similar to those for the entire ONWM area, in terms of the area-averaged simulated water depths for the water-budget components. Simulated ET of $27.9 \mathrm{in} / \mathrm{yr}$ (about 4.3 million acre-ft/yr) was about 77 percent of the precipitation inflow of $36.5 \mathrm{in} / \mathrm{yr}$ (about 5.6 million acre-ft/yr). Simulated streamflow from the ONIHM area was $7.3 \mathrm{in} / \mathrm{yr}$ (about 1.1 million acre-ft/yr), or about 20 percent of the precipitation inflow. Similar to results for the entire ONWM area, simulated recharge of $4.7 \mathrm{in} / \mathrm{yr}$ (about 0.7 million acre-ft/yr) was the third largest component of the 100 -year simulated water budget for the ONIHM area and was about 13 percent of precipitation.

Results for the ONWM and ONIHM areas indicated that most of the simulated recharge was discharged back to the stream network as the base-flow component of streamflow. Base flow accounted for 71 percent of recharge ( $3.0 \mathrm{in} / \mathrm{yr}$ ) for the ONWM area and 74 percent of recharge (3.5 in/yr) for the ONIHM area. A smaller amount of the recharge, averaging $1.2 \mathrm{in} / \mathrm{yr}$ for the ONWM and ONIHM areas (about 0.5 million acre- $\mathrm{ft} / \mathrm{yr}$ for the ONWM area and 0.2 million acre-ft/yr for the ONIHM area), or about 29 to 26 percent of total recharge, respectively, was simulated as a groundwater outflow or loss. This simulated net groundwater loss amounted to about 3 percent of precipitation in the ONWM and ONIHM areas and was included in the ONWM to represent groundwater processes that were not directly simulated, such as groundwater ET, groundwater pumping, and groundwater underflow. These groundwater processes are more appropriately simulated using groundwater-flow models.

\section{Annual Results}

Annual results for water years 1915-2014 had substantial year-to-year variability in simulated water-budget components, primarily in response to the year-to-year variability in precipitation. The most precipitation, 57.8 inches, fell in water year 1999, compared to only 18.5 inches in water year 1956 , the driest year in the 100 -year period. The 100 -year cumulative departure from mean annual precipitation indicated a long-term shift in annual precipitation around water year 1984. Mean annual precipitation for water years $1915-85$ was 35 inches, compared to 39 inches for water years 1986-2014. Overall, 55 years were drier than average in the 100-year period, indicating drier than average conditions 55 percent of the time.

The lowest annual recharge was 1.5 inches, simulated for the water year 1956, the driest year, and the highest annual recharge for the ONWM area was 8.8 inches, simulated for water year 1999, the wettest year. The highest recharge was simulated as streamflow losses for channel locations in valley bottoms with thick, permeable alluvium. High to intermediate amounts of recharge also were simulated for interchannel areas underlain by permeable bedrock. Streamflow was the most variable from year-to-year compared to other components of the hydrologic system. The most annual streamflow was 18.9 inches simulated for water year 1999, the wettest year. The lowest annual streamflow was 1.7 inches, simulated for water year 1966, which was a relatively dry year, but not the driest year in the simulation period.

\section{Monthly and Average Monthly Results}

The monthly time series of recharge (combined soil-zone recharge and seepage from water bodies and river channels), expressed as the mean for the area of the ONWM, ranged from high values of 1.4 to 1.6 inches (for total monthly recharge) to low values of about 0.06 to 0.1 inch and less. The monthly time series of streamflow ranged from high values of 4.0 to 7.1 inches (for total monthly streamflow) to low values of about 0.05 to 0.1 inch and less. The annual and monthly time series for streamflow and recharge indicated an increase in the frequency and magnitude of wet periods during the second one-half of the simulation period (water years 1973-2014). The cumulative departures from mean monthly recharge and streamflow indicated a shift from lower than average to higher than average monthly recharge and streamflow starting approximately with water year 1973. Standardized monthly recharge and streamflow indices were calculated using a 48-month (4-year) interval to help identify wetter and drier than average periods. The indices identified 4-year periods ending with water years 1975-76, 1987-88, 1995, 2000-01, and 2010 as having index values greater than or equal to 1.5 , thereby indicating notably wetter than average periods compared to the 100 -year means for monthly recharge and streamflow, and 4-year periods ending with water years 1939-40, 1954-57, 1965-68 as having index values less than or equal to -1.5 , thereby indicating notably drier than average periods compared to the 100 -year means. The wettest 4-year periods in the simulation in terms of recharge and streamflow ended with water years 1975, 1987, 1988, and 2000, based on high index values of close to 2.0, and the driest 4-year periods in terms of recharge and streamflow ended with water years 1955-56, and 1966-67, based on low index values of less than approximately -2.0 .

Mean monthly precipitation for water years 19152014 indicated a bimodal distribution for mean monthly precipitation, with peaks during the spring and late summer to early fall. May and June were the wettest months in the ONWM area, with 4.8 inches of precipitation in May and 4.9 inches in June. September was the third wettest month, with a mean of 4.0 inches of precipitation. January was the driest month, with a mean precipitation of about 1.2 inches for water years 1915-2014. The distribution of simulated mean monthly streamflow was similar to precipitation, with May and June having the highest mean streamflow of 0.93 inches. 
Unlike precipitation, however, the third highest mean monthly streamflow of 0.75 inches was in April rather than September because of wetter soils simulated for April compared to September. The mean monthly results for simulated recharge were similar to those for simulated streamflow such that the months with the most recharge were May ( 0.46 inch) and June ( 0.45 inch). Unlike the results for precipitation and streamflow indicating the lowest values for January, the lowest simulated mean monthly recharge was in August ( 0.25 inch) because of higher ET in August resulting in decreased soil moisture compared to lower ET and increased soil moisture in January. The different distributions in mean monthly results for precipitation, streamflow, and recharge were caused by the greater PET during the summer compared with winter months, resulting in more recharge and streamflow during the winter and spring, when PET is relatively low and the soil-zone water content is high.

\section{Daily Results}

Simulation results indicated a high degree of variability in daily streamflow, with three to four orders of magnitude difference between maximum and minimum daily streamflows. The daily simulation results for the 100-year simulation (with river inflows excluded) ranged from very low streamflows of $0.01 \mathrm{ft}^{3} / \mathrm{s}$ and less to a maximum daily streamflow of about $92,000 \mathrm{ft}^{3} / \mathrm{s}$. Streamflows simulated for the Arkansas River at the outflow from the ONWM area included a maximum daily mean streamflow of $90,590 \mathrm{ft}^{3} / \mathrm{s}$ and a minimum daily mean streamflow of $209 \mathrm{ft}^{3} / \mathrm{s}$. Simulated daily streamflow at the Caney River outflow from the ONWM area ranged from about 66 to $73,900 \mathrm{ft}^{3} / \mathrm{s}$, and daily streamflow at the Bird Creek outflow from the ONWM area ranged from about 52 to $35,250 \mathrm{ft}^{3} / \mathrm{s}$. The simulated 100-year mean streamflow from the ONWM area was $4,331 \mathrm{ft}^{3} / \mathrm{s}$, with a mean streamflow of $2,368 \mathrm{ft}^{3} / \mathrm{s}$ at the Arkansas River outflow, $1,216 \mathrm{ft}^{3} / \mathrm{s}$ at the Caney River outflow, and $747 \mathrm{ft}^{3} / \mathrm{s}$ at the Bird Creek outflow. Results for subdrainages with areas of about $100 \mathrm{mi}^{2}$ included 100-year mean streamflows of about 19 to $60 \mathrm{ft}^{3} / \mathrm{s}$, maximum daily streamflows of about 6,000 to $14,000 \mathrm{ft}^{3} / \mathrm{s}$, and minimum daily streamflows of about 0.07 to $7.0 \mathrm{ft}^{3} / \mathrm{s}$. Results for smaller subdrainages with areas of 1 to $10 \mathrm{mi}^{2}$ included mean streamflows of about 0.8 to $7 \mathrm{ft}^{3} / \mathrm{s}$, maximum daily streamflows of about 70 to $1,200 \mathrm{ft}^{3} / \mathrm{s}$, and minimum daily streamflows of $0.4 \mathrm{ft}^{3} / \mathrm{s}$ or less. In general, daily results for most of the smaller, headwater stream segments indicated very low streamflows of less than $0.2 \mathrm{ft}^{3} / \mathrm{s}$ during dry periods and were considered representative of ephemeral to intermittent conditions. Maximum and minimum daily mean streamflows for many of the stream segments with contributing areas of $100 \mathrm{mi}^{2}$ and smaller differed by a range of approximately four orders of magnitude, indicating that streamflow was the most variable component of the simulated water budget for the ONWM area.

\section{Simulation Results for Water Years 1938-2014}

Streamflow records for water years 1938-2014 from seven USGS streamgages along the western boundary of the ONWM were used to develop river inflows from five tributary drainages upstream from the ONWM area. The 77-year mean combined inflow from the five tributary drainages was $6,106 \mathrm{ft}^{3} / \mathrm{s}$. The mean streamflow simulated from the ONWM contributing area in response to precipitation during water years 1938-2014 was 4,468 $\mathrm{ft}^{3} / \mathrm{s}$, resulting in a combined mean streamflow of about 10,570 $\mathrm{ft}^{3} / \mathrm{s}$ from the ONWM area, including a mean streamflow of $8,552 \mathrm{ft}^{3} / \mathrm{s}$ for the Arkansas River outflow, a mean streamflow of $1,252 \mathrm{ft}^{3} / \mathrm{s}$ for the Caney River outflow, and a mean streamflow of $771 \mathrm{ft}^{3} / \mathrm{s}$ for the Bird Creek outflow. The simulated 77-year mean streamflow discharged from the ONIHM area was $7,420 \mathrm{ft}^{3} / \mathrm{s}$, which included a mean inflow of $5,804 \mathrm{ft}^{3} / \mathrm{s}$ from nine upstream tributary subbasins combined with a mean streamflow of $1,616 \mathrm{ft}^{3} / \mathrm{s}$ from the ONIHM contributing area.

The results for the simulation in which the five river inflows were included indicated a maximum daily mean streamflow of about $191,700 \mathrm{ft}^{3} / \mathrm{s}$ for the Arkansas River at the outflow from the ONWM area, compared to a maximum daily mean streamflow of about $90,590 \mathrm{ft}^{3} / \mathrm{s}$ for the simulation in which the river flows were excluded. In the simulation in which the five river inflows were included, the maximum daily mean streamflow was about $147,600 \mathrm{ft}^{3} / \mathrm{s}$ at the Arkansas River outflow from the Keystone Lake-Arkansas River subbasin, which defined the maximum daily mean streamflow from the ONIHM area. In comparison, the maximum daily mean streamflow for the Keystone Lake-Arkansas River subbasin from the simulation in which the five river inflows were excluded was about $84,660 \mathrm{ft}^{3} / \mathrm{s}$. The effect of including the five river inflows on simulated streamflow was not as pronounced for minimum daily mean streamflows as for the maximum daily mean streamflows. The simulated minimum daily mean streamflow at the Arkansas River outflow from the ONWM area from the simulation in which the five river inflows were included was $240 \mathrm{ft}^{3} / \mathrm{s}$. In comparison, using the simulation in which the five river inflows were excluded, the minimum daily mean streamflow at the Arkansas River outflow from the ONWM area was $209 \mathrm{ft}^{3} / \mathrm{s}$. Unlike the Arkansas River subdrainage, simulated streamflows for the Caney River and Bird Creek subdrainages were not affected by including the river inflows in the ONWM simulation. 
Monthly mean streamflows simulated by the ONWM are likely to be the most useful as the boundary inflows for the ONIHM area and the MODFLOW-OWHM simulations. For the simulation in which the five river inflows were included, maximum monthly mean streamflows simulated for the ONIHM area included about $62,040 \mathrm{ft}^{3} / \mathrm{s}$ for the Keystone Lake-Arkansas River subbasin and about $58,890 \mathrm{ft}^{3} / \mathrm{s}$ for the Sooner Lake-Arkansas River subbasins. In comparison, the simulation in which the river inflows were excluded had a maximum monthly mean streamflow of about $28,620 \mathrm{ft}^{3} / \mathrm{s}$ for the Keystone Lake-Arkansas River subbasin and about $21,900 \mathrm{ft}^{3} / \mathrm{s}$ for the Sooner Lake-Arkansas River subbasin. Maximum monthly mean inflows to the ONIHM area were about 31,030 $\mathrm{ft}^{3} / \mathrm{s}$ for the Kaw Lake-Arkansas River subbasin and about $22,950 \mathrm{ft}^{3} / \mathrm{s}$ for the Salt Fork Arkansas River subbasin using simulations with the five river inflows. In comparison, maximum monthly mean inflows to the ONIHM area were $5,832 \mathrm{ft}^{3} / \mathrm{s}$ for the Kaw Lake-Arkansas River subbasin and 2,849 $\mathrm{ft}^{3} / \mathrm{s}$ for the Salt Fork Arkansas River subbasin using the simulations without the five river inflows.

\section{Model Limitations}

The ONWM was considered successful for its intended purposes of (1) simulating the long-term water budget for the ONWM area, (2) simulating the spatial and temporal variability of water-budget components for the ONWM area, and (3) simulating the boundary inflows to the ONIHM. Understanding model limitations, however, is important for determining appropriate model applications, evaluating results, and qualitatively assessing model uncertainty. The ONWM model limitations were associated with limitations in the data used to develop, calibrate, and apply the model; limitations in the simplifying assumptions needed to represent the hydrologic system using a computer model; and limitations in the simplifying assumptions used to represent physical processes by computer algorithms.

The ONWM used daily precipitation and air-temperature records from 203 climate stations to develop the daily climate inputs; however, only a subset of these stations were active at any given time during the 100 -year simulation period. Results for the earlier part of the simulation period, prior to about water year 1948, are likely to have greater uncertainty because there were fewer active climate stations compared to the later part of the simulation. Additionally, some areas in the ONWM had few climate stations; therefore, the simulation results for HRUs in these areas are likely to have a higher degree of uncertainty.

The ONWM includes an empirical adjustment of precipitation intensity to account for seasonal differences in storm characteristics. However, this simplified approach might not adequately represent the high hourly precipitation rates from convective storms, which can result in a larger contribution of Hortonian runoff to total streamflow.

Many of the critical PRMS parameters were not measured, but rather were estimated and then adjusted during the model calibration process. The final calibrated values were considered reasonable estimates but might not be representative of actual field conditions. In addition, many of the parameters were estimated using available datasets representing field conditions at the time of this study, such as land-cover type, the percentage of impervious land cover, and the percentage of forest-canopy cover. At some locations, these estimated values might not be representative of conditions in the early part of the simulation period. The most important change not directly represented by the ONWM is the construction of reservoirs and the transition to managed river flows at different times during the simulation period. Other changes through time not represented by the model include increased diversions of surface water and changes in irrigation practices.

An important limitation of the ONWM is that the groundwater system was represented by an empirical groundwater-storage and discharge model that does not take into account the three-dimensional heterogeneity of aquifer systems and the physics of groundwater storage and flow. The groundwater system simulated by the ONWM represents only the "active" part of groundwater storage contributing to streamflow. This empirical simulation of the groundwater system did not allow for the representation of rejected recharge for locations that had a high water table, and this could cause an overestimation of recharge. Groundwater traveltimes and flow paths through the unsaturated zone underlying the active root zone were not explicitly simulated by the ONWM. Groundwater losses due to pumping, saturated zone ET, and underflow beneath the ONWM boundary were not directly accounted for by the ONWM, although these water losses were indirectly simulated by using a groundwater-sink term in the water budget.

Additional model limitations include simplified representations of water bodies, streamflow, and surface water-groundwater interactions. Streambed leakage in stream segments was not simulated by the ONWM. The depression storage module was used to indirectly simulate the larger water bodies and the riparian areas of larger stream channels. This method of simulating water bodies did not directly account for riparian and saturated zone ET, diversions, managed flows, and infiltration of streamflow simulated in stream segments. 
The ONWM is intended to provide a preliminary assessment of water resources for the Osage Nation and the ONIHM area. To perform a more detailed and comprehensive simulation of the hydrologic system that includes more physically based streamflow dynamics, reservoir operations, groundwater pumping, riparian and saturated zone ET, flow diversions, surface water and groundwater interactions, and groundwater flow, an integrated hydrologic model, like MODFLOW-OWHM, would be needed for the ONIHM area. Application of MODFLOW-OWHM for the ONIHM domain can allow for a more detailed simulation of surface water and groundwater supplies, including the anthropogenic components of the hydrologic system, such as surface-water flow diversions, reservoir operations, and groundwater pumping.

\section{Introduction}

The Osage Nation is a 2,304-square-mile $\left(\mathrm{mi}^{2}\right)$ area in northeastern Oklahoma that is coincident with the historical boundaries of the Osage Nation Reservation and Osage County (fig. 1A). The term "Osage Nation" is used interchangeably in this report for the members of the Osage Nation, their tribal government, and the land area in which many tribal members reside. Knowledge of the quantity and quality of water resources is limited in the Osage Nation (Andrews and Smith, 2014). A tribal water plan can be used to help manage the sustainable development of surface-water and groundwater resources, thereby helping to provide a better future for the Osage Nation and their neighbors, while preserving water resources for the benefit of the surrounding environment and future generations. To help meet these goals and contribute to increased knowledge of the quantity and quality of water resources, the U.S. Geological Survey (USGS) in cooperation with the Osage Nation began studies to evaluate the surface-water and groundwater resources of the Osage Nation. An important component of these studies is the development and application of numerical models to improve quantification and understanding of the hydrologic system. These models are needed to estimate and quantify the effects of historical and potential future water resource development for the Osage Nation.

Sustainable use of surface-water and groundwater resources in the Osage Nation can be evaluated with groundwater and surface-water computer models that are calibrated to observations defined by available records of field measurements or estimates developed from field measurements representing current and historical conditions. The computer models can be used to simulate and identify the effects of climate variations and changes in water withdrawals and land use on freshwater and saline-water resources in the Osage Nation (Andrews and Smith, 2014). An integrated hydrologic model enables the simulation of groundwater and surface-water flow processes as well as surface and subsurface water-storage components, providing a detailed and comprehensive estimation of the water budget (Hanson and others, 2014). In addition, an integrated hydrologic model allows for an efficient and dynamic coupling of the hydrologic system with temporally and spatially variable climate conditions and land-use changes, providing reliable estimates of the effects of variations and trends in climate and land use on the water resources (Hanson and others, 2014).

The purpose of this study was to develop a precipitationrunoff model, the Osage Nation watershed model (ONWM), with application to quantify surface-water hydrology and boundary conditions for use in a fully integrated hydrologic model, the Osage Nation integrated hydrologic model (ONIHM) (fig. 1A). The ONWM and OHNIHM models can be used to simulate all components of the hydrologic system in the Osage Nation, to estimate the long-term availability of water resources, and to test the response of the hydrologic system to various water and land-use management scenarios for the Osage Nation. As a component of the ONIHM, precipitation-runoff processes simulated by the ONWM can improve the understanding of the land surface and shallow subsurface (soil zone) hydrologic processes and enable a broader, more comprehensive analysis of the effects of climate variability and potential climate change as well as potential changes in hydrography, land cover, and soil properties on the integrated hydrologic system for the Osage Nation. Application of the ONWM as a component of the ONIHM can enable the simulation of a fully comprehensive water budget, including the use and movement of water in the landscape, in the root zone and shallow subsurface, in the surface-water network, and in aquifers.

The ONWM was developed using the USGS Precipitation Runoff Modeling System, version 4 (PRMS-IV) computer software (Markstrom and others, 2015), also referred to as PRMS in this report, for an $8,343-\mathrm{mi}^{2}$ study area in northeastern Oklahoma and southeastern Kansas, centered on and including the areas of the Osage Nation and the ONIHM (fig. 1A). The intended use of the ONIHM is to simulate all surface-water and groundwater components of the hydrologic system for a 2,905- $\mathrm{mi}^{2}$ area centered on the Osage Nation (fig. 1A). The specific objectives of this study are to use the ONWM to (1) provide a systematic inventory of the historical distribution of precipitation falling on the land surface as either rain or snow and then infiltrating soils, returning to the atmosphere by evapotranspiration (ET), percolating through the root zone to become recharge, and flowing through the surface-water network as surface runoff, interflow, and base flow; (2) provide a historical context of the variability and spatial and temporal distribution of the water; and (3) estimate the inflow boundary conditions for the ONIHM. The ONIHM inflow boundary conditions and water-budget components include (1) precipitation (as either rain or snow), (2) potential evapotranspiration (PET), (3) ET, (4) streamflow and the components of streamflow, and (5) recharge and the components of recharge. 


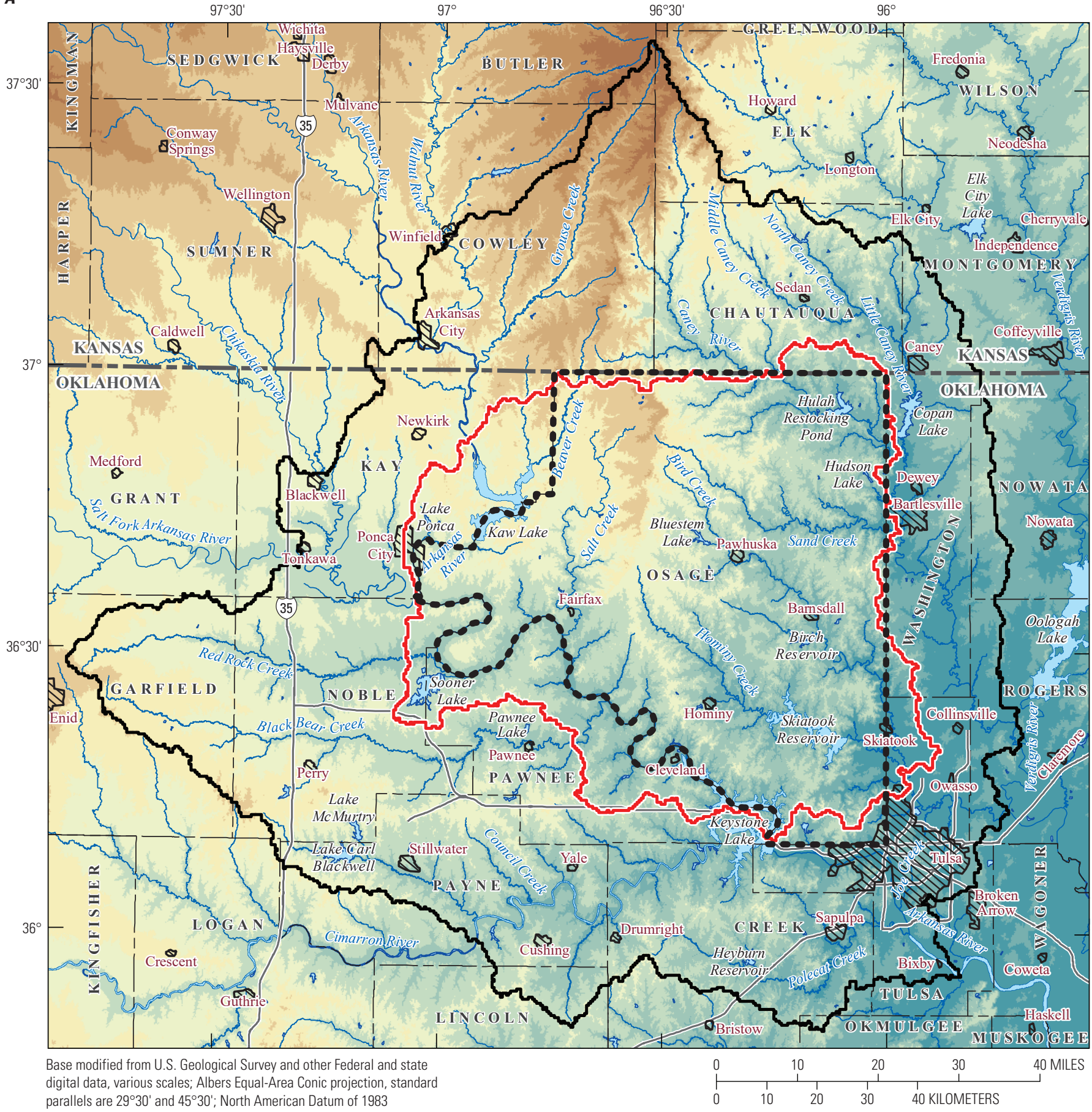

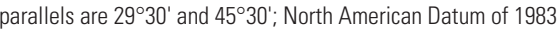

EXPLANATION

\begin{tabular}{|c|c|}
\hline \multicolumn{2}{|c|}{$\begin{array}{l}\text { Land-surface elevation, in feet } \\
\text { (from Gesch and others, 2009) }\end{array}$} \\
\hline $496-700$ & $1,101-1,200$ \\
\hline $701-800$ & $1,201-1,300$ \\
\hline $801-900$ & $1,301-1,400$ \\
\hline $901-1,000$ & $1,401-1,500$ \\
\hline $1,001-1,100$ & $1,501-1,681$ \\
\hline
\end{tabular}
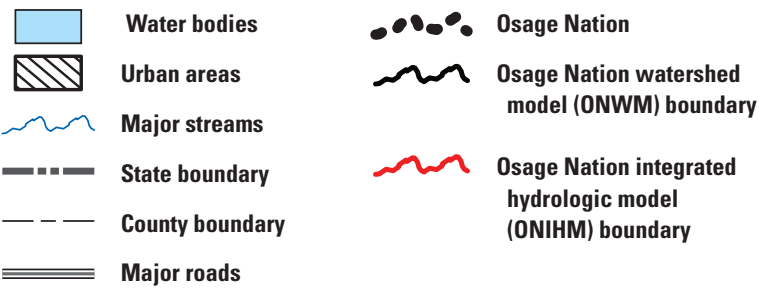

Figure 1. The Osage Nation watershed model and the Osage Nation integrated hydrologic model areas, Oklahoma and Kansas: $A$, study area and land elevation, $B$, study area location relative to regional surface water drainages defined by 4-digit hydrologic units, and $C$, major surface-water drainages and sub-drainages within the 0 sage Nation watershed model. 


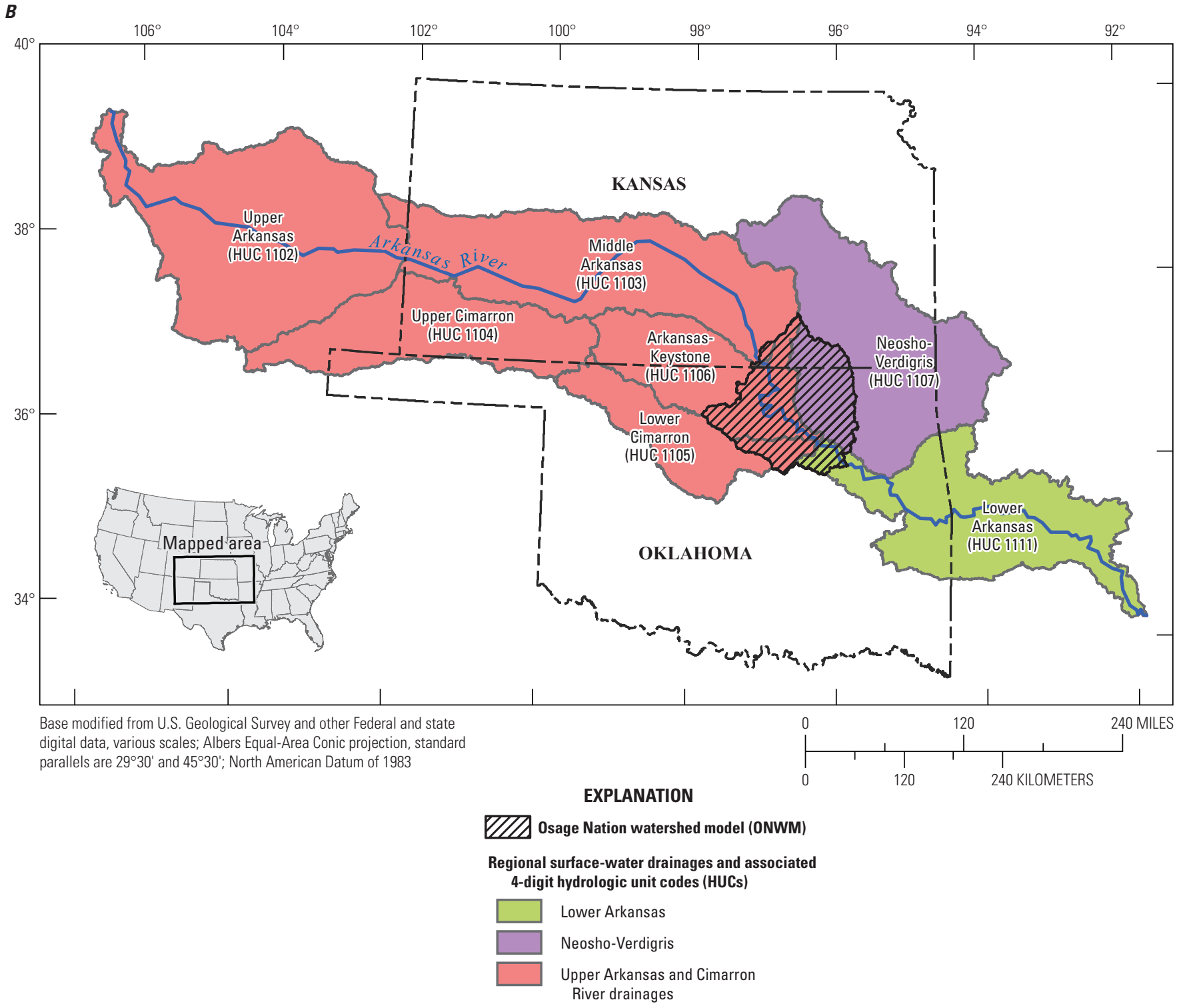

Figure 1. - Continued 


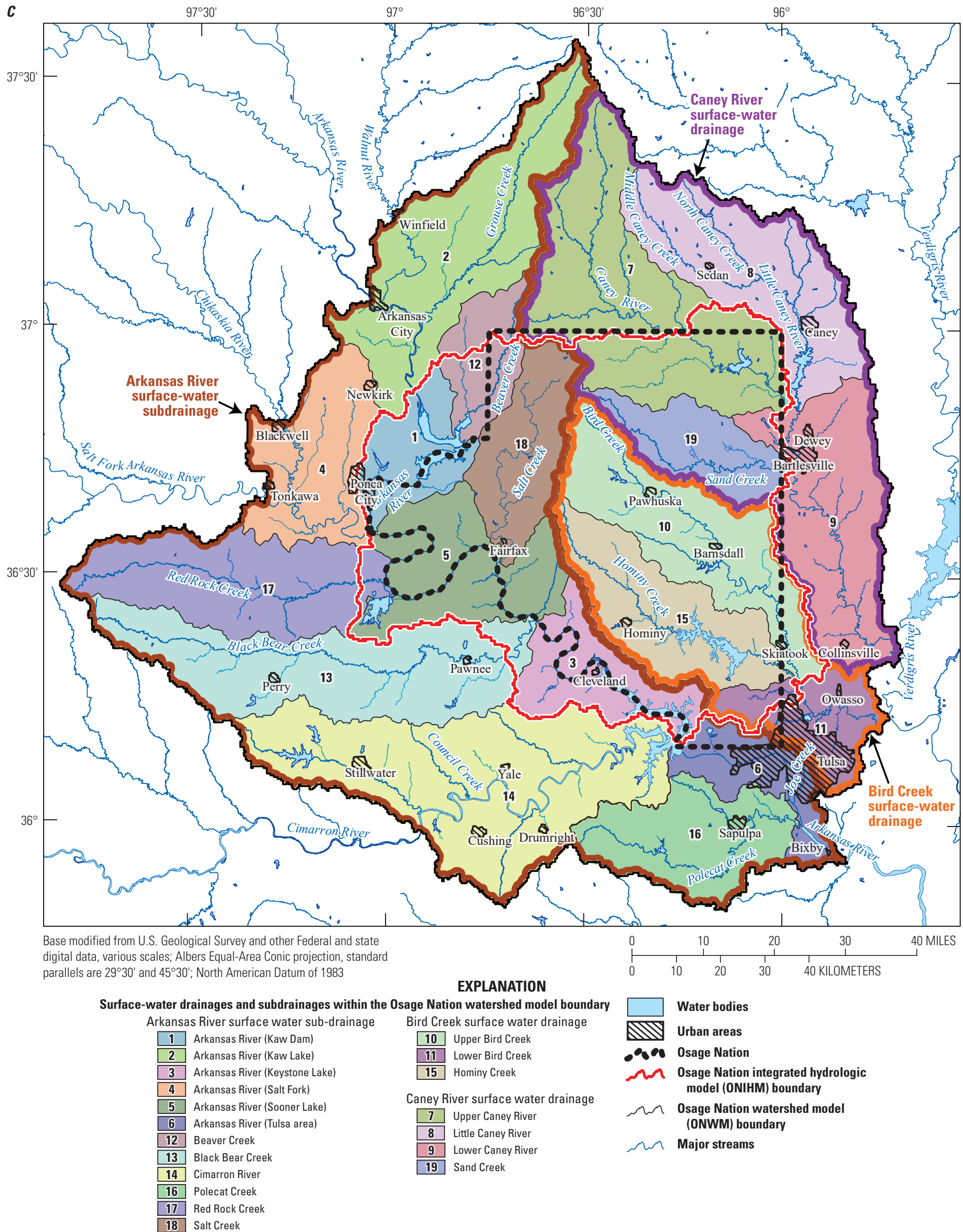

Figure 1. - Continued 


\section{Purpose and Scope}

This report describes the development, calibration, and application of the ONWM to quantify precipitationrunoff processes, including surface-water flow components, ET, and recharge, for the development of a preliminary water budget for the Osage Nation and for the development of boundary conditions used in the ONIHM. To meet the study objectives, the ONWM was used to simulate a 100 -year water budget for the period from October 1, 1914, to September 30, 2014 (water years 1915-2014); a water year is the 12-month period October 1 through September 30 designated by the calendar year in which it ends. The spatial domain of the ONWM was defined for a region around and including the areas of the Osage Nation and the ONIHM in order to simulate surface-water drainages outside of and tributary to the ONIHM area, thereby ensuring that all inflow boundary conditions potentially affecting the ONIHM area are thoroughly represented (figs. 1, 2). The ONWM used a daily time step to incorporate daily climate inputs of precipitation and air temperature. The ONWM simulations accounted for climate, surface, and shallow subsurface components of the hydrologic system, including surface water and shallow groundwater, with an emphasis on hydrologic processes at the land surface and in the shallow subsurface including the upper soil layer and the root zone.

\section{Previous Investigations}

The hydrology and hydrogeology of the Osage Nation have recently been evaluated by the USGS, in cooperation with the Osage Nation (Andrews and Smith, 2014). The study summarized existing hydrologic data and identified gaps in those data to facilitate better understanding of the water resources in the Osage Nation for planning future development and water use (Andrews and Smith, 2014). In their analysis of streamflow records, Andrews and Smith (2014) concluded that streamflows in the Osage Nation were substantially affected by annual to decadal variability in precipitation, with an approximate 100-percent increase in annual streamflows during the relatively wet periods from the 1970 s to 2000 , followed by an approximate 50-percent decrease in annual streamflows during the relatively drier periods in the early 2000 s.

Using estimates of freshwater resources in local streams, lakes, freshwater aquifers, and net annual precipitation, Andrews and Smith (2014) estimated that less than 1 percent of freshwater resources were withdrawn annually in the

\section{EXPLANATION}

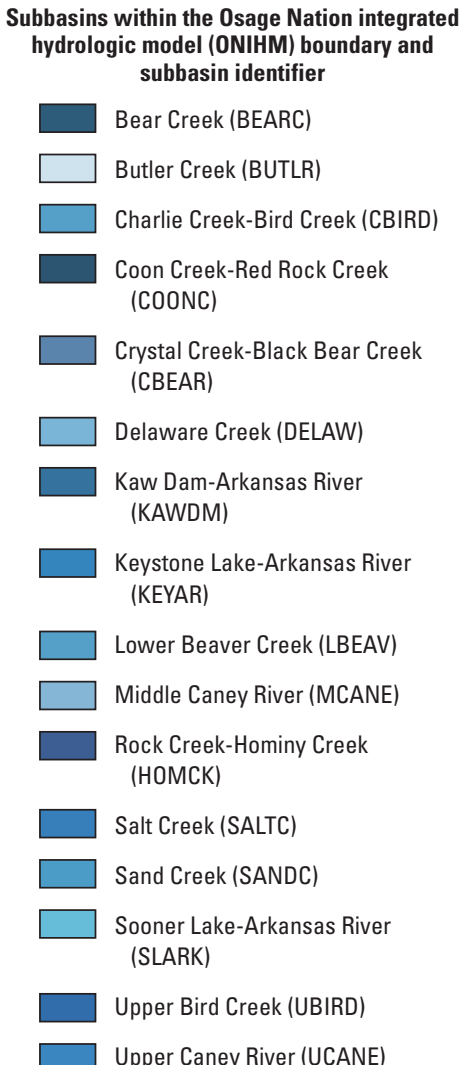

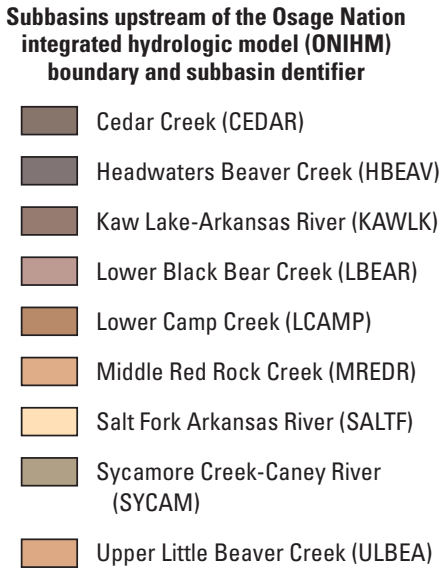

Peripheral subbasins and subbasin identifier Keystone Lake-Cimarron River (KEYCR)

$\square$ Little Caney River (LICAN)

Lower Bird Creek (LBIRD)

Lower Caney River (LCANE)

Polecat Creek (POLEC)

Skull Creek-Cimarron River (SKULL)

Lower Arkansas River (LWARK)

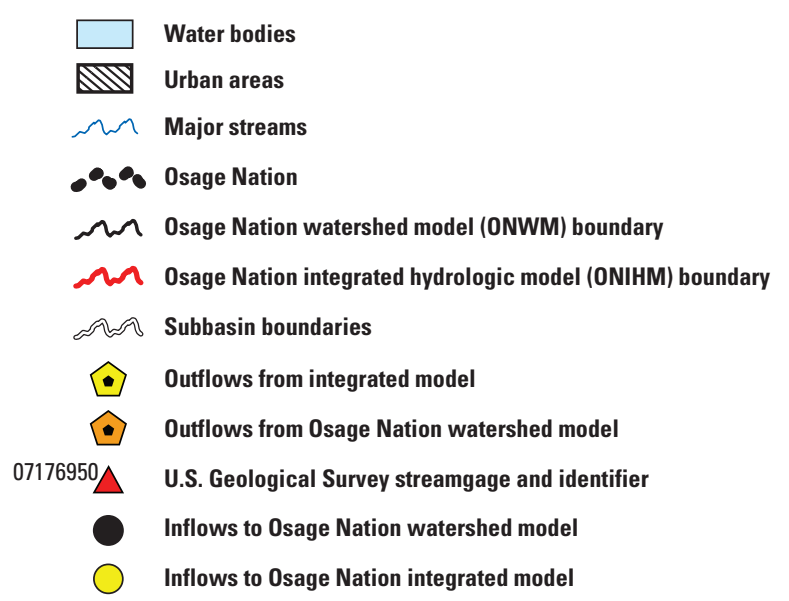

Figure 2. Surface-water subbasins, inflows, outflows, and streamgages included in the Osage Nation watershed model, Oklahoma and Kansas.

Osage Nation at the time of their study. Their study included estimates of increasing water use in the Osage Nation from 1980 through 2010, with freshwater withdrawals increasing from 841 to 18,150 acre-feet per year (acre-ft/yr) and groundwater withdrawals increasing from about 146 to 2,680 acre-ft/yr. 


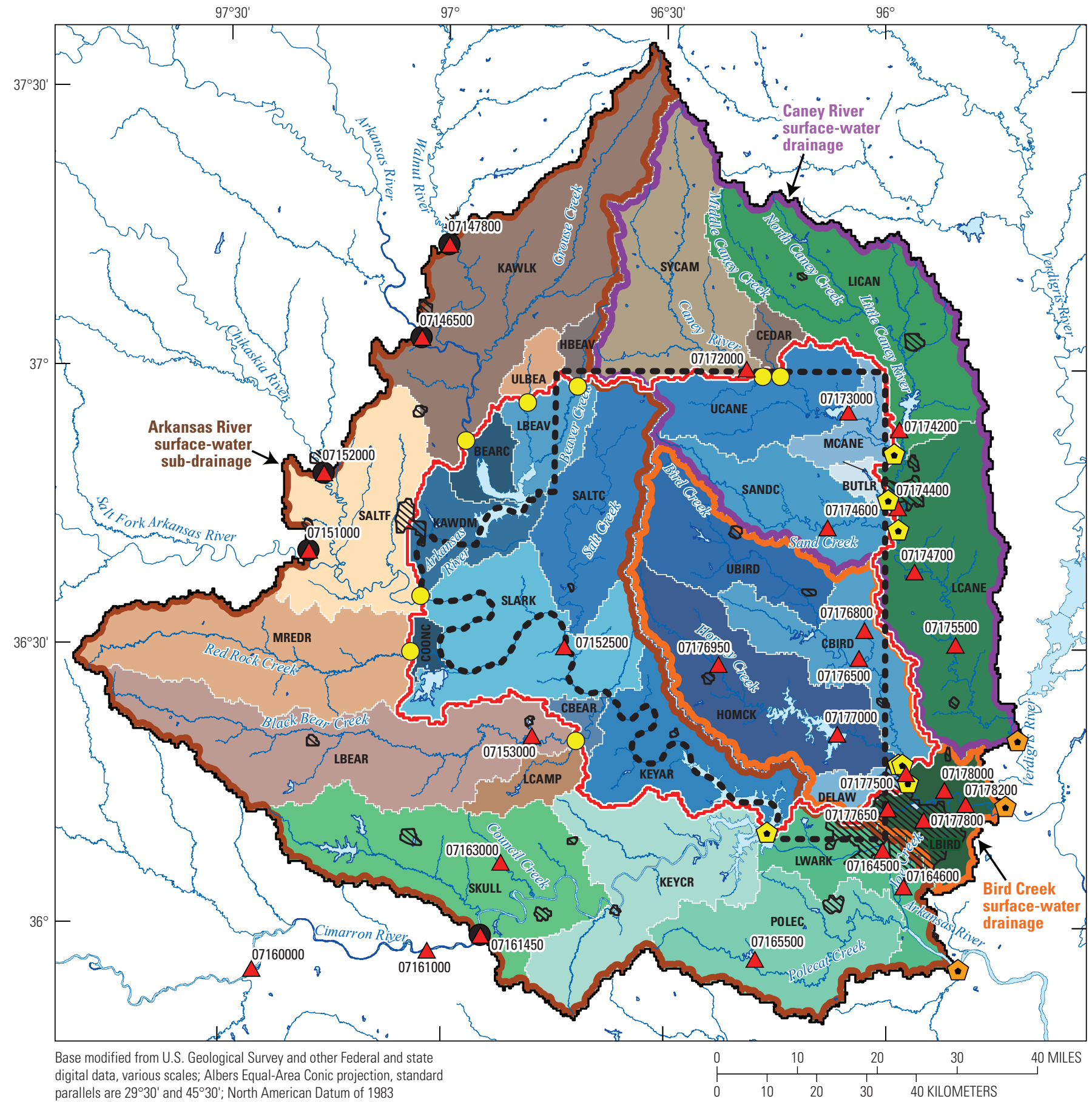

Figure 2. - Continued

The main bedrock aquifer underlying the Osage Nation, the Ada-Vamoosa aquifer of northeastern Oklahoma, was studied by the USGS to evaluate potential groundwater resources (Abbott and DeHay, 2008). The Ada-Vamoosa is a sedimentary bedrock aquifer contained in the Pennsylvanianage Ada Group and underlying Pennsylvanian-age Vamoosa
Formation that crop out over 800 square miles of the Osage Nation. Abbot and DeHay (2008) concluded that additional information regarding the production potential of the AdaVamoosa aquifer is needed to aid the Osage Nation plan for development of the groundwater resource. 


\section{Study Area}

The ONWM domain was defined by an $8,343-\mathrm{mi}^{2}$ study area centered on and surrounding the 2,300- $\mathrm{mi}^{2}$ area of the Osage Nation and the 2,905-mi area of the ONIHM domain (fig. 1). The southern two-thirds of the ONWM area is in northeastern Oklahoma, and the northern one-third extends into southern Kansas (fig. $1 B$ ). The ONWM area includes all or part of the areas of 5 counties in southern Kansas and 15 counties in northeastern Oklahoma. The ONIHM boundary defines the areal extent of the groundwater flow model component of the ONIHM, centered on the Osage Nation. At the time of this study, the groundwater flow model component was being developed using the computer code MODFLOWOne-Water-Hydrologic-Model (MF-OWHM, Hanson and others, 2014; MF-OWHMv2, Boyce and others, 2020). The MF-OWHM component is intended to be used for a detailed and comprehensive simulation of the integrated surface-water and groundwater hydrologic system for the Osage Nation.

The ONWM is in the lower (downstream) section of hydrologic region 11 that includes the upper Arkansas River drainage basin (Seaber and others, 1987). The ONWM includes partial areas of 3 regional surface water drainages: (1) the Upper Arkansas, (2) the Lower Arkansas, and (3) the Neosho-Verdigris (fig. 1B). The Upper Arkansas regional drainage includes 5 subdrainages; (1) the upper Arkansas, (2) the Middle Arkansas, (3) the Arkansas-Keystone, (4) the Upper Cimarron, and (5) the Lower Cimarron (fig. 1B). The combined parts of the Upper and Lower Arkansas River regional surface water drainages within the ONWM comprise a 5,100- $\mathrm{mi}^{2}$ subdrainage of the Arkansas River Basin that includes the western and southern parts of the Osage Nation, ONIHM, and ONWM, and is herein referred to as the Arkansas River surface-water subdrainage (fig. 1C). The partial area of the Neosho-Verdigris regional surface water drainage within the ONWM includes two tributary drainages to the Verdigris River; (1) the 2,100- $\mathrm{mi}^{2}$ Caney River drainage in the northeastern parts of the Osage Nation, ONIHM, and ONWM areas, and (2) the 1,100- $\mathrm{mi}^{2}$ Bird Creek drainage in the central and southeastern parts of the Osage Nation, ONIHM, and ONWM areas (fig. 1C). The Verdigris River drainage on the eastern side of the ONWM is a tributary of the Arkansas River and joins the Arkansas River southeast of the ONWM boundary.

\section{Hydrography}

The ONWM boundary was defined primarily by hydrologic unit code (HUC)-10 and HUC-12 boundaries (see illustration of hierarchy at the begining of this report; Seaber and others, 1987; https://water.usgs.gov/GIS/huc.html, accessed September 2015). The HUC boundaries are defined on the basis of known topographic divides and surfacewater basins (Seaber and others, 1987; McKay and others, 2012). A total of 35 complete or partial HUC-10 areas and
221 complete or partial HUC-12 areas are included in the ONWM area.

As with the ONWM, the ONIHM boundary was defined by surface-water drainage divides based on HUC-10 and HUC-12 boundaries (figs. 1C, 2). The ONIHM boundary was first matched to the boundary of the Osage Nation and then was modified to match to the HUC-10 and HUC-12 boundaries to provide a more efficient and exact accounting of the water budget for the Osage Nation using the integrated modeling approach; a small part of the Osage Nation along the northern, eastern, and southern boundary was excluded from the ONIHM. These excluded areas are outside of the surfacewater drainages defining the ONIHM study area. The ONIHM includes areas to the west of the Osage Nation, defined primarily by HUC-12 boundaries, which were considered to be potentially relevant to the groundwater system underlying the Osage Nation, particularly in terms of alluvial aquifers and basins along the Arkansas River, which defines the western boundary of the Osage Nation. The matching of the ONIHM boundaries to the surface-water drainage divides was done primarily to allow for an exact integration of the ONWM surface-water flow paths with the ONIHM boundary. Additionally, it was assumed that the groundwater divides and flow paths underlying the Osage Nation are at least partly controlled by the surface-water drainage divides.

The ONWM area was divided into 32 subbasins and 3 subbasin groups on the basis of the intersection of the HUC-10 and HUC-12 boundaries with the ONIHM boundary (see illustration of hierarchy at the begining of this report; fig. 2; table 1). The subbasins define surface-water drainages and were used in the ONWM to analyze water budgets for subareas of the ONWM area and to develop inflow and outflow boundary conditions for the ONIHM model domain. The two general directions of surface-water flow in these subbasins is form north to south and west to east. Nine subbasins - Cedar Creek, Sycamore Creek-Caney River, Headwaters Beaver Creek, Upper Little Beaver Creek, Kaw Lake-Arkansas River, Salt Fork Arkansas River, Middle Red Rock Creek, Lower Black Bear Creek, and Lower Camp Creek-define tributary surface-water drainages upstream from the northern, western, and southwestern parts of the ONIHM area (fig. 2; table 1). These nine subbasins are the "upstream subbasins" in this study. The upstream subbasins drain south and east toward the ONIHM boundary and the Osage Nation, contributing surface-water inflows and potentially contributing additional inflows consisting of groundwater underflow originating from recharge in the upstream drainages.

The ONIHM area includes 16 subbasins, 8 of which receive inflows from the 9 upstream subbasins and 7 of which include surface-water outflows from the ONIHM area (fig. 2; table 1). The major drainages in the Osage Nation and the ONIHM area are Beaver Creek and Salt Creek in the northwestern section, Caney River and Sand Creek in the northeastern section, Bird Creek in the east-central section, and Hominy Creek in the central and southeastern sections. 
Table 1A. Surface-water subbasin areas used in the Osage Nation watershed model (ONWM), Oklahoma and Kansas.

[See figure 2. Abbreviations: HRUs, hydrologic response units; $\mathrm{mi}^{2}$, square mile; —, not applicable]

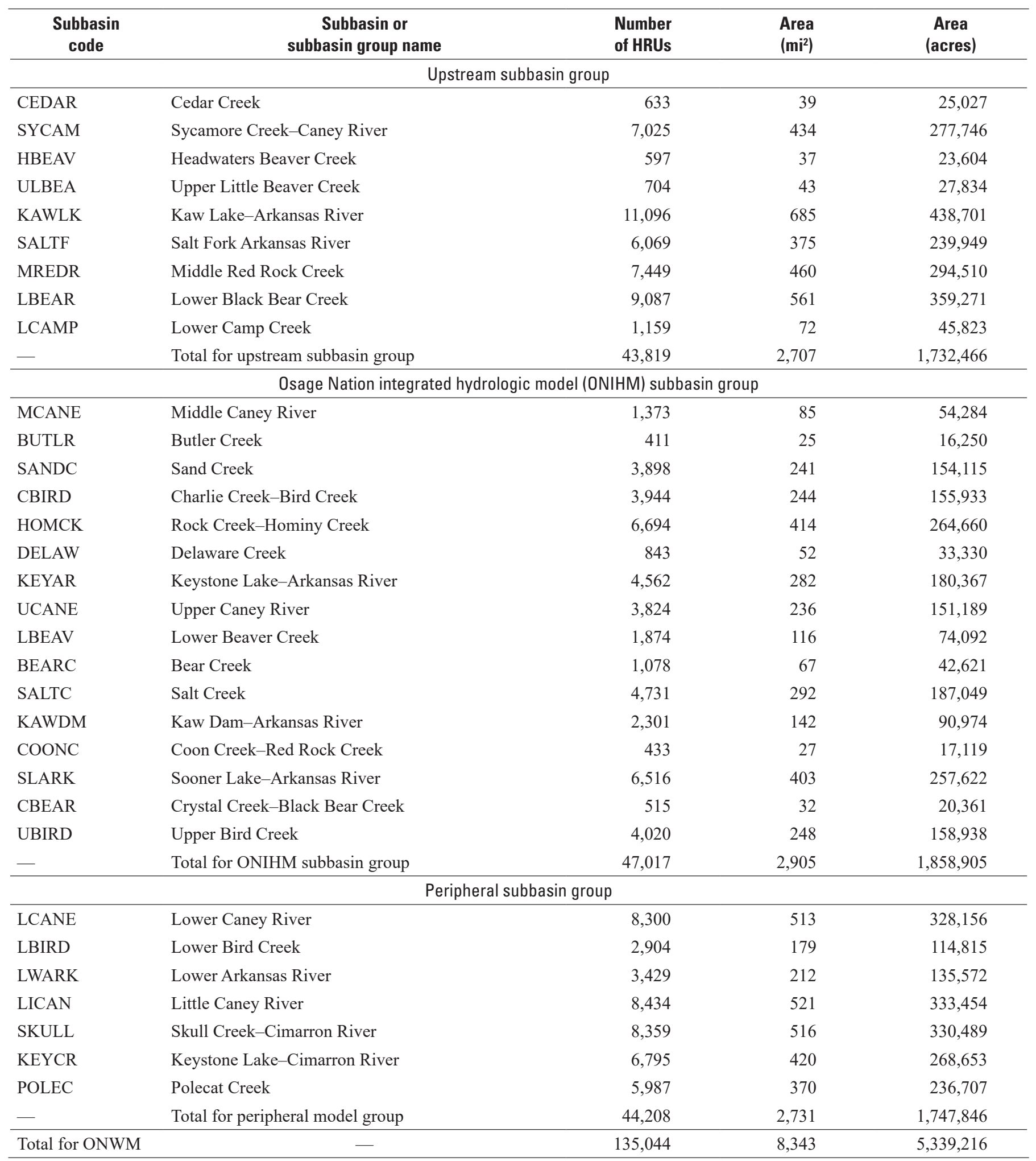


Table 1B. Surface-water subbasin inflows and outflows used in the Osage Nation watershed model (ONWM), Oklahoma and Kansas.

[See figure 2. Abbreviation: HRUs, hydrologic response units]

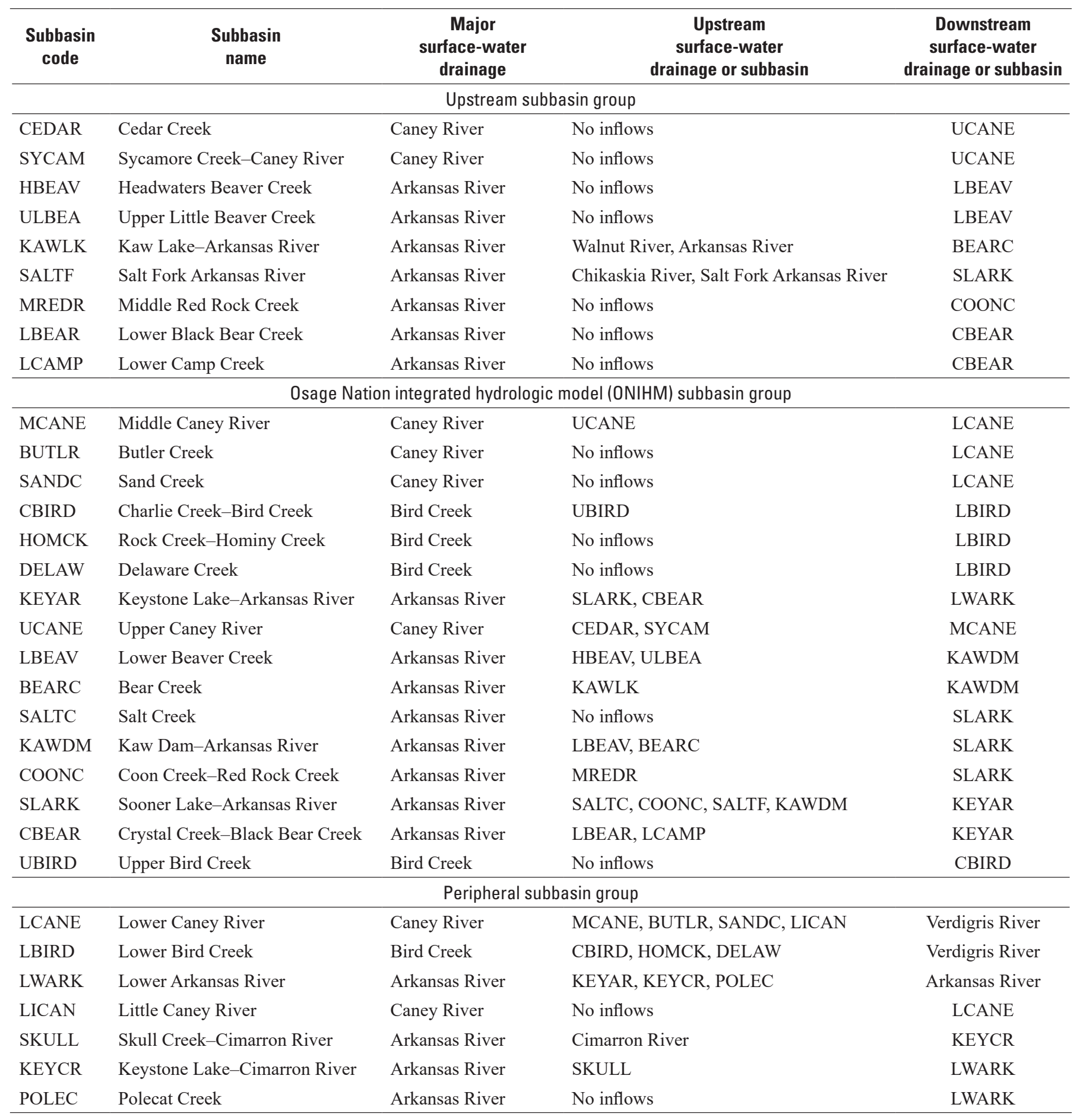


The Arkansas River drains the western and southwestern sections of the ONIHM area. The Osage Nation is bounded on the west and southwest for 123 miles by the Arkansas River (Andrews and Smith, 2014). Streamflow is generally from north to south in the northwestern part of the ONIHM and from northwest to southeast in the eastern, central, southern, and southwestern sections.

The ONWM area includes seven subbasins outside of the ONIHM area that are the "peripheral subbasins" in this study (fig. 2; table 1). The peripheral subbasins do not contribute streamflow to the ONIHM area. The 2,731- $\mathrm{mi}^{2}$ area of the peripheral subbasins was included in the ONWM domain for the purpose of model calibration and to allow for eastward and southward expansion or modification of the ONIHM area. There are 8 inflows to the peripheral subbasin area; the outflows from the 7 subbasins draining the ONIHM and the inflow from the Cimarron River.

The Arkansas River subdrainage in the ONWM area receives river inflows from five major surface-water drainages upstream from and tributary to the ONWM area: (1) the main stem of the upper Arkansas River, (2) the Walnut River, (3) the Chikaskia River, (4) the Salt Fork of the Arkansas River, and (5) the Cimarron River (table 1). With the exception of the Cimarron River, all of these river inflows contribute to the inflows to the ONIHM area. For this study, including these large upstream drainage areas as part of the ONWM domain was not desirable because of a potential loss in modeling efficiency, increased simulation times, and the increased data requirements needed for the expanded model area. To limit the areal extent of the ONWM along the western and northwestern sides of the Osage Nation, the areas of the five upstream drainages were not explicitly included in the ONWM; instead, the western and northwestern boundaries of the ONWM were defined by a combination of HUC-10 boundaries and the locations of seven USGS streamgages that had long-term streamflow records used to define the river inflows from the upstream areas (figs. 1, 2; table 2). Records from four streamgages (WALW, ARKA, CHIB, and SFAT) were directly used for defining inflows from the Walnut River, the Arkansas River, the Chikaskia River, and the Salt Fork of the Arkansas River. Three streamgages (CIMG, CIMP, and CIMR) were used with the maintenance of variance estimation (MOVE1) record-extension method (Hirsch, 1982) to develop an extended record defining inflows from the Cimarron River to the peripheral subbasins in the southern part of the ONWM. In addition to the 7 streamflow records used to define the boundary inflows to the ONWM, streamflow records from 22 streamgages in the ONWM area were used for model development and calibration (fig. 2; table 2).

\section{Climate}

The climate of the ONWM area is temperate (Oklahoma Climatological Survey, 2013). Climate is a critical characteristic and controlling factor of the hydrologic system, and precipitation and air temperature are the primary components of climate affecting hydrology. Variations in the timing, frequency, amount, and spatial distributions of precipitation are all important characteristics directly affecting the hydrologic system. Spatial and temporal variations in air temperature, as well as diurnal variations between maximum and minimum daily temperatures, affect the energy available for ET and the type of precipitation (rain or snow).

\section{Precipitation}

Daily precipitation for all locations in the ONWM was estimated for water years 1910-2014 using spatial interpolation (Hevesi and others, 2011b; Flint and Martin, 2012; Woolfenden and Nishikawa, 2014; Hevesi and Christensen, 2015). The spatial interpolation was done using daily records from 203 climate stations in and around the ONWM area (fig. 3; table 3), and grid-based maps of estimated 30-year normal (mean) monthly precipitation for 1981-2010 calculated by the Parameter-elevation Regressions on Independent Slopes Model (PRISM; Daly and others, 1994, 2004). Records for 184 of the 203 stations were obtained using the USGS Downsizer application (Ward-Garrison and others, 2009) and consisted primarily of records from the National Oceanic and Atmospheric Cooperative Observer Network (https://www.ncdc.noaa.gov/data-access/land-based-stationdata/land-based-datasets/cooperative-observer-networkcoop, accessed September 2015). Records for 10 of the 184 stations were supplemented using data obtained from the Oklahoma Climatological Survey's (OCS) Mesonet database (https://www.mesonet.org/, accessed September 2015). Records for 19 of the 203 stations were obtained from the OCS Mesonet database (https://www.mesonet.org/, accessed September 2015) and were in addition to the records obtained for the 184 stations using Downsizer.

The estimated 100-year basinwide mean annual precipitation for water years 1915-2014 was 36.1 inches in the ONWM area and varied from a maximum of 41 inches along the northeastern boundary to a minimum of 30 inches along the western boundary (fig. 3). In general, precipitation increased from west to east in the ONWM area, and the areas of highest precipitation were near the northeastern and southeastern boundary of the ONWM. In the ONIHM area, mean annual precipitation varied from about 38 inches in the central and eastern parts to about 34 inches along the western side (fig. 3). 
Table 2. Streamgages with daily mean discharge records used in the development and calibration of the Osage Nation watershed model (ONWM), Oklahoma and Kansas.

$\left[\mathrm{mi}^{2}\right.$, square miles; $\mathrm{mm} / \mathrm{dd} / \mathrm{yyyy}$, month/day/year]

\begin{tabular}{|c|c|c|c|c|c|c|c|c|}
\hline $\begin{array}{c}\text { Code for } \\
\text { streamgage and } \\
\text { contributing } \\
\text { subdrainage } \\
\text { (see fig. 21) }\end{array}$ & Streamgage identification and name & $\begin{array}{l}\text { Latitude } \\
\text { (decimal } \\
\text { degrees) }\end{array}$ & $\begin{array}{c}\text { Longitude } \\
\text { (decimal } \\
\text { degrees) }\end{array}$ & $\begin{array}{c}\text { Total } \\
\text { drainage } \\
\text { area within } \\
\text { ONWM } \\
\left(\mathrm{mi}^{2}\right)\end{array}$ & $\begin{array}{c}\text { Record } \\
\text { starting date } \\
(\mathrm{mm} / \mathrm{dd} / \mathrm{yyyy})^{1}\end{array}$ & $\begin{array}{c}\text { Record } \\
\text { ending date } \\
\text { (mm/dd/ } \\
\text { yyyy) }\end{array}$ & $\begin{array}{c}\text { Gage } \\
\text { status }^{2}\end{array}$ & $\begin{array}{l}\text { Use of } \\
\text { record }\end{array}$ \\
\hline ARKA & USGS 07146500 Arkansas River at Arkansas City, KS & 37.0564 & -97.0578 & 0 & $10 / 01 / 1921$ & $09 / 30 / 2014$ & Active & Inflow \\
\hline WALW & USGS 07147800 Walnut River at Winfield, KS & 37.2239 & -96.9958 & 0 & $11 / 14 / 1921$ & $09 / 30 / 2014$ & Active & Inflow \\
\hline SFAT & USGS 07151000 Salt Fork Arkansas River at Tonkawa, OK & 36.6719 & -97.3092 & 0 & $10 / 01 / 1935$ & $09 / 30 / 2014$ & Active & Inflow \\
\hline CHIB & USGS 07152000 Chikaskia River near Blackwell, OK & 36.8114 & -97.2769 & 0 & 04/01/1936 & $09 / 30 / 2014$ & Active & Inflow \\
\hline ARKR & USGS 07152500 Arkansas River at Ralston, OK & 36.5042 & -96.7281 & 2,516 & $10 / 01 / 1925$ & $09 / 30 / 2014$ & Active & Calibration \\
\hline BLAP & USGS 07153000 Black Bear Creek at Pawnee, OK & 36.3436 & -96.7992 & 539 & 07/29/1944 & $09 / 30 / 2014$ & Active & Calibration \\
\hline CIMG & USGS 07160000 Cimarron River near Guthrie, OK & 35.9206 & -97.4256 & 0 & $10 / 01 / 1937$ & $09 / 30 / 2014$ & Active & Inflow \\
\hline CIMP & USGS 07161000 Cimarron River at Perkins, OK & 35.9575 & -97.0317 & 0 & $10 / 01 / 1939$ & 09/30/1991 & Inactive & Inflow \\
\hline CIMR & USGS 07161450 Cimarron River near Ripley, OK & 35.9858 & -96.9119 & 0 & $10 / 01 / 1987$ & $09 / 30 / 2014$ & Active & Inflow \\
\hline COUS & USGS 07163000 Council Creek near Stillwater, OK & 36.1161 & -96.8675 & 31 & $04 / 01 / 1934$ & $09 / 30 / 1993$ & Inactive & Calibration \\
\hline ARKT & USGS 07164500 Arkansas River at Tulsa, OK & 36.1406 & -96.0061 & 4,647 & $10 / 01 / 1925$ & $09 / 30 / 2014$ & Active & Calibration \\
\hline JOET & USGS 07164600 Joe Creek at 61st St at Tulsa, OK & 36.0756 & -95.9603 & 12 & 03/11/1988 & $09 / 30 / 2014$ & Active & Calibration \\
\hline POLH & USGS 07165500 Polecat Creek below Heyburn Reservoir near Heyburn, OK & 35.9450 & -96.2942 & 121 & $10 / 01 / 1943$ & 09/30/1979 & Inactive & Calibration \\
\hline CANE & USGS 07172000 Caney River near Elgin, KS & 37.0039 & -96.3164 & 427 & $10 / 01 / 1939$ & $09 / 30 / 2014$ & Active & Calibration \\
\hline CANH & USGS 07173000 Caney River near Hulah, OK & 36.9269 & -96.0850 & 710 & $10 / 01 / 1937$ & 09/30/1993 & Inactive & Calibration \\
\hline LCRC & USGS 07174200 Little Caney River below Cotton Creek, near Copan, OK & 36.8950 & -95.9692 & 504 & $10 / 01 / 1958$ & 02/10/1981 & Inactive & Calibration \\
\hline CANB & USGS 07174400 Caney River above Coon Creek at Bartlesville, OK & 36.7556 & -95.9719 & 1,370 & $10 / 01 / 1985$ & $09 / 30 / 2014$ & Active & Calibration \\
\hline SANO & USGS 07174600 Sand Creek at Okesa, OK & 36.7194 & -96.1322 & 138 & $10 / 01 / 1959$ & 09/30/1993 & Inactive & Calibration \\
\hline CANO & USGS 07174700 Caney River near Ochelata, OK & 36.6406 & -95.9339 & 1,732 & 04/01/1956 & 09/30/1976 & Inactive & Calibration \\
\hline CANR & USGS 07175500 Caney River near Ramona, OK & 36.5089 & -95.8417 & 1,935 & $10 / 01 / 1945$ & $09 / 30 / 2014$ & Active & Calibration \\
\hline BIRA & USGS 07176500 Bird Creek at Avant, OK & 36.4850 & -96.0600 & 368 & $10 / 01 / 1945$ & $09 / 30 / 2014$ & Active & Calibration \\
\hline CDYW & USGS 07176800 Candy Creek near Wolco, OK & 36.5350 & -96.0483 & 32 & $10 / 01 / 1969$ & 05/18/1981 & Inactive & Calibration \\
\hline HOMH & USGS 07176950 Hominy Creek near Hominy, OK & 36.4736 & -96.3786 & 116 & $10 / 01 / 2003$ & 09/30/2007 & Inactive & Calibration \\
\hline HOMS & USGS 07177000 Hominy Creek near Skiatook, OK & 36.3486 & -96.1097 & 339 & 04/01/1944 & 09/30/1981 & Inactive & Calibration \\
\hline BIRS & USGS 07177500 Bird Creek near Sperry, OK & 36.2783 & -95.9539 & 910 & $10 / 01 / 1938$ & $09 / 30 / 2014$ & Active & Calibration \\
\hline FLAT & USGS 07177650 Flat Rock Creek at Cincinnati Ave at Tulsa, OK & 36.2153 & -95.9950 & 8.2 & $12 / 01 / 1987$ & $09 / 30 / 2014$ & Active & Calibration \\
\hline COAT & USGS 07177800 Coal Creek at Tulsa, OK & 36.1944 & -95.9139 & 8.5 & 01/30/1988 & $09 / 30 / 2014$ & Active & Calibration \\
\hline BIRO & USGS 07178000 Bird Creek near Owasso, OK & 36.2486 & -95.8669 & 1,023 & $10 / 01 / 1935$ & $09 / 30 / 2014$ & Active & Calibration \\
\hline BIRC & USGS 07178200 Bird Creek at State Highway 266 near Catoosa, OK & 36.2231 & -95.8192 & 1,123 & 08/01/1988 & $09 / 30 / 2014$ & Active & Calibration \\
\hline
\end{tabular}

${ }^{1}$ Record dates refer to records used in this study and may not represent the complete available record.

${ }^{2}$ Gage status refers to gage operation up until September 2014. 


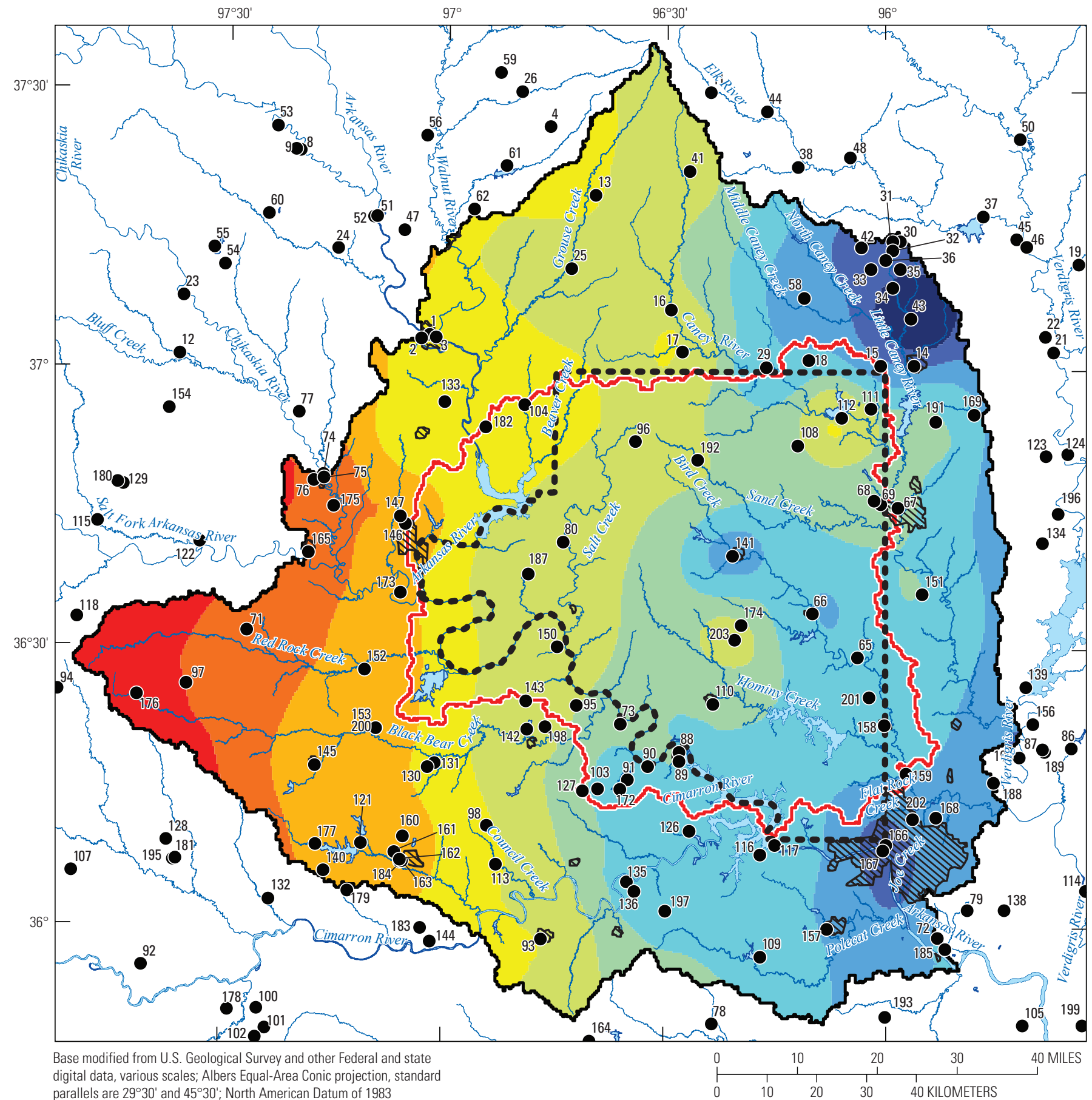

parallels are $29^{\circ} 30^{\prime}$ and $45^{\circ} 30^{\prime}$; North American Datum of 1983

EXPLANATION

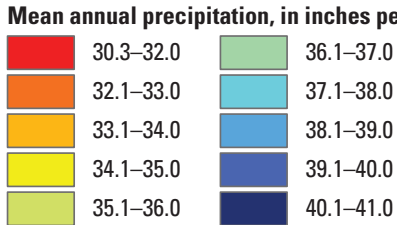

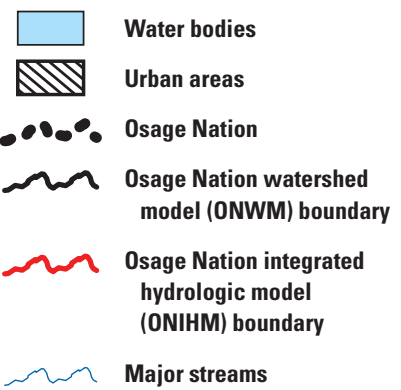

105 Climate station and identification (see table 3 for details)

Figure 3. Spatially distributed mean annual precipitation estimated for water years 1915-2014 for the Osage Nation watershed model, Oklahoma and Kansas. 
Table 3. Climate stations with records used to develop daily precipitation and air-temperature inputs for the Osage Nation watershed model (ONWM), Oklahoma and Kansas.

[deg., degrees; ft, feet; ID, identification; min., minutes; NAD83, North American horizontal Datum of 1983; NAVD 88, North American Vertical Datum of 1988; sec., seconds; - , data not available or not applicable]

\begin{tabular}{|c|c|c|c|c|c|c|c|c|c|}
\hline Station name & $\begin{array}{c}\text { Station } \\
\text { number } \\
\text { (fig. 3) }\end{array}$ & State & County & $\begin{array}{l}\text { Station } \\
\text { code }\end{array}$ & $\begin{array}{l}\text { Latitude } \\
\text { (deg. min. } \\
\text { sec.) }\end{array}$ & $\begin{array}{c}\text { Longitude } \\
\text { (deg. min. sec.) }\end{array}$ & $\begin{array}{c}\text { Albers } \\
\text { NAD83 } \\
\text { projection } \\
\text { easting } \\
\text { coordinate } \\
\text { (meters) }\end{array}$ & $\begin{array}{c}\text { Albers } \\
\text { NAD83 } \\
\text { projection } \\
\text { northing } \\
\text { coordinate } \\
\text { (meters) }\end{array}$ & $\begin{array}{c}\text { Elevation } \\
\text { (ft above } \\
\text { NAVD 88) }\end{array}$ \\
\hline \multicolumn{10}{|c|}{ Data source: Downsizer } \\
\hline Arkansas & 3 & $\mathrm{KS}$ & Cowley & 140316 & $370329.88 \mathrm{~N}$ & $0970130.00 \mathrm{~W}$ & $-90,292.4$ & $1,557,775.6$ & 1,079 \\
\hline Atlanta & 4 & $\mathrm{KS}$ & Cowley & 140424 & $372613.92 \mathrm{~N}$ & $0964600.84 \mathrm{~W}$ & $-67,214.3$ & $1,600,019.5$ & 1,430 \\
\hline Augusta & $5 *$ & $\mathrm{KS}$ & Butler & 140447 & $374153.88 \mathrm{~N}$ & $0965814.16 \mathrm{~W}$ & $-84,767.9$ & $1,629,443.2$ & 1,230 \\
\hline Augusta 2 & $6^{*}$ & KS & Butler & 140453 & $374014.16 \mathrm{~N}$ & $0965848.00 \mathrm{~W}$ & $-85,620.9$ & $1,626,347.3$ & 1,194 \\
\hline Big Hill Lake & $10 *$ & $\mathrm{KS}$ & Labette & 140810 & $371632.88 \mathrm{~N}$ & $0952822.08 \mathrm{~W}$ & $46,306.6$ & $1,581,789.5$ & 876 \\
\hline Blaine & 11 & KS & Elk & 140875 & $373000.00 \mathrm{~N}$ & $0962400.00 \mathrm{~W}$ & $-35,028.3$ & $1,606,860.0$ & - \\
\hline Caldwell & 12 & KS & Sumner & 141233 & $370128.92 \mathrm{~N}$ & $0973633.12 \mathrm{~W}$ & $-141,814.3$ & $1,554,724.5$ & 1,142 \\
\hline Cambridge & 13 & $\mathrm{KS}$ & Cowley & 141239 & $371854.00 \mathrm{~N}$ & $0963945.00 \mathrm{~W}$ & $-58,159.8$ & $1,586,256.7$ & 1,260 \\
\hline Caney & 14 & KS & Montgomery & 141266 & $370037.08 \mathrm{~N}$ & $0955608.16 \mathrm{~W}$ & $5,676.8$ & $1,551,912.2$ & 761 \\
\hline Caney $4 \mathrm{~W}$ & 15 & $\mathrm{KS}$ & Chautauqua & 141282 & $370037.08 \mathrm{~N}$ & $0960041.04 \mathrm{~W}$ & $-1,004.9$ & $1,551,910.3$ & 899 \\
\hline Cedar Vale $1 \mathrm{NE}$ & 16 & KS & Chautauqua & 141393 & $370636.00 \mathrm{~N}$ & $0962921.84 \mathrm{~W}$ & $-43,082.1$ & $1,563,192.8$ & 896 \\
\hline City 1 SE Cedar Vale 5 SSE & 17 & KS & Chautauqua & 141395 & $370204.92 \mathrm{~N}$ & $0962747.16 \mathrm{~W}$ & $-40,808.1$ & $1,554,743.7$ & 879 \\
\hline Chautaugua & 18 & KS & Chautauqua & 141460 & $370113.08 \mathrm{~N}$ & $0961030.00 \mathrm{~W}$ & $-15,423.9$ & $1,553,045.0$ & 942 \\
\hline Dalton Rome & 24 & KS & Sumner & 141994 & $371300.12 \mathrm{~N}$ & $0971500.00 \mathrm{~W}$ & $-109,878.2$ & $1,575,761.0$ & - \\
\hline Dexter & 25 & KS & Cowley & 142126 & $371059.88 \mathrm{~N}$ & $0964300.12 \mathrm{~W}$ & $-63,029.2$ & $1,571,533.2$ & 1,142 \\
\hline Douglass & 26 & $\mathrm{KS}$ & Butler & 142189 & $373000.00 \mathrm{~N}$ & $0964959.88 \mathrm{~W}$ & $-72,972.0$ & $1,607,106.2$ & 1,201 \\
\hline E1 Dorado & $27 *$ & $\mathrm{KS}$ & Butler & 142401 & $374905.88 \mathrm{~N}$ & $0965039.84 \mathrm{~W}$ & $-73,627.0$ & $1,642,786.8$ & 1,289 \\
\hline El Dorado $1 \mathrm{E}$ & $28 *$ & KS & Butler & 142403 & $374900.84 \mathrm{~N}$ & $0965021.12 \mathrm{~W}$ & $-73,175.0$ & $1,642,625.8$ & 1,293 \\
\hline Elgin & 29 & KS & Chautauqua & 142409 & $370025.92 \mathrm{~N}$ & $0961619.92 \mathrm{~W}$ & $-23,995.0$ & $1,551,597.3$ & 801 \\
\hline Elk City 5 SW SCS 1 & 30 & $\mathrm{KS}$ & Chautauqua & 142422 & $371359.88 \mathrm{~N}$ & $0955800.12 \mathrm{~W}$ & $2,926.6$ & $1,576,899.0$ & 932 \\
\hline Elk City 6 SW & 31 & $\mathrm{KS}$ & Chautauqua & 142423 & $371359.88 \mathrm{~N}$ & $0955859.88 \mathrm{~W}$ & $1,467.7$ & $1,576,898.6$ & 922 \\
\hline Elk City 7 SSW SCS 4 & 32 & $\mathrm{KS}$ & Chautauqua & 142425 & $371300.12 \mathrm{~N}$ & $0955859.88 \mathrm{~W}$ & $1,468.0$ & $1,575,038.4$ & 869 \\
\hline Elk City 8 SW SCS 5 & 33 & KS & Chautauqua & 142426 & $371200.00 \mathrm{~N}$ & $0960000.00 \mathrm{~W}$ & 0.0 & $1,573,166.9$ & 860 \\
\hline Elk City 10 SW & 34 & KS & Chautauqua & 142427 & $371059.88 \mathrm{~N}$ & $0960159.88 \mathrm{~W}$ & $-2,928.5$ & $1,571,296.1$ & 869 \\
\hline Elk City 10 SSW & 35 & KS & Chautauqua & 142428 & $370900.00 \mathrm{~N}$ & $0955859.88 \mathrm{~W}$ & $1,469.3$ & $1,567,564.2$ & 810 \\
\hline Elk City 8 SSW & 36 & $\mathrm{KS}$ & Chautauqua & 142429 & $371059.88 \mathrm{~N}$ & $0955800.12 \mathrm{~W}$ & $2,928.5$ & $1,571,296.1$ & 879 \\
\hline Elk City Lake & 37 & KS & Montgomery & 142430 & $371639.00 \mathrm{~N}$ & $0954636.84 \mathrm{~W}$ & $19,595.6$ & $1,581,874.6$ & 850 \\
\hline
\end{tabular}


Table 3. Climate stations with records used to develop daily precipitation and air-temperature inputs for the 0sage Nation watershed model (ONWM), Oklahoma and Kansas.-Continued

[deg., degrees; ft, feet; ID, identification; min., minutes; NAD83, North American horizontal Datum of 1983; NAVD 88, North American Vertical Datum of 1988; sec., seconds; - , data not available or not applicable]

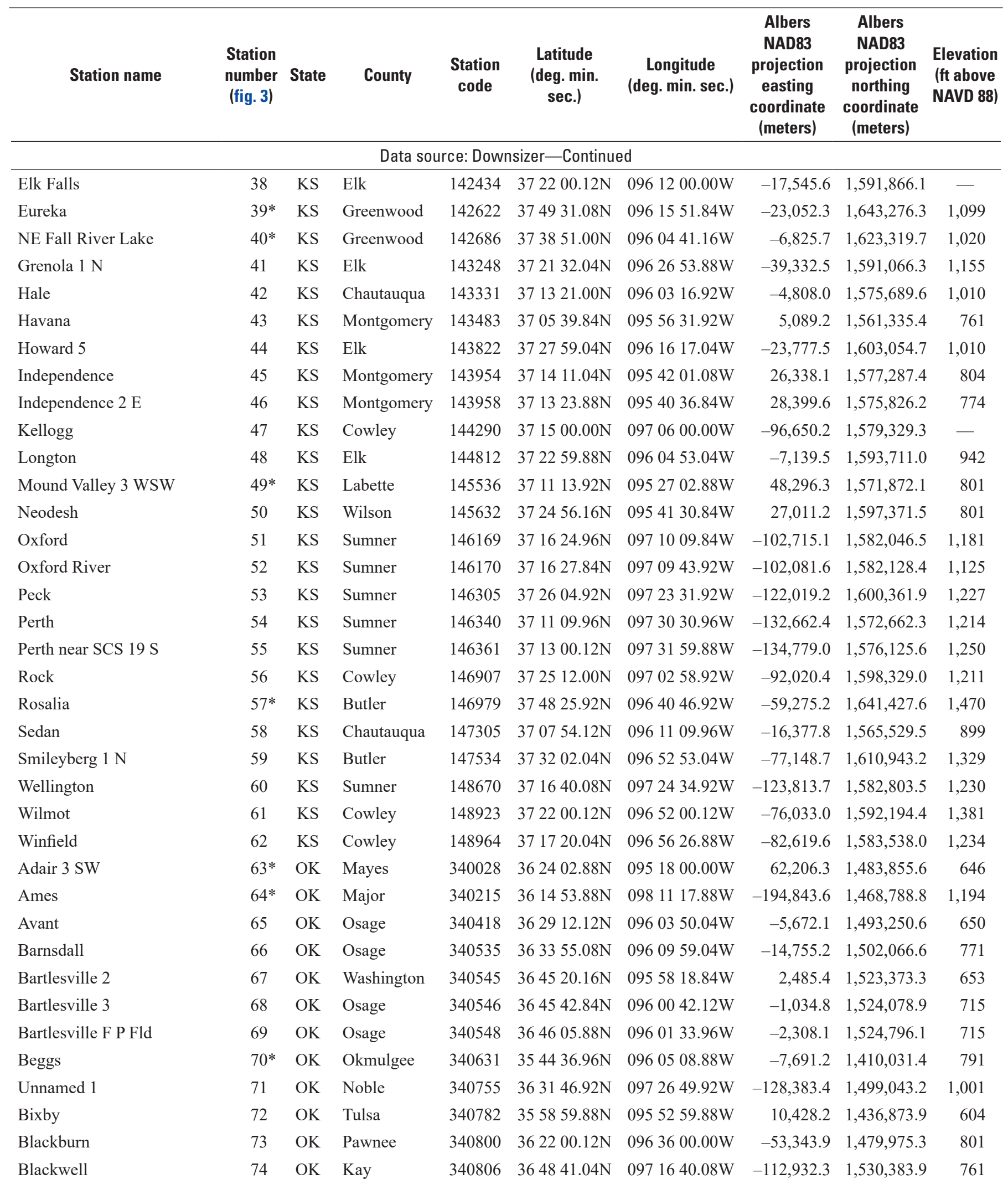


Table 3. Climate stations with records used to develop daily precipitation and air-temperature inputs for the Osage Nation watershed model (ONWM), Oklahoma and Kansas. - Continued

[deg., degrees; ft, feet; ID, identification; min., minutes; NAD83, North American horizontal Datum of 1983; NAVD 88, North American Vertical Datum of 1988; sec., seconds; - , data not available or not applicable]

\begin{tabular}{|c|c|c|c|c|c|c|c|c|c|}
\hline Station name & $\begin{array}{c}\text { Station } \\
\text { number } \\
\text { (fig. 3) }\end{array}$ & State & County & $\begin{array}{c}\text { Station } \\
\text { code }\end{array}$ & $\begin{array}{l}\text { Latitude } \\
\text { (deg. min. } \\
\text { sec.) }\end{array}$ & $\begin{array}{c}\text { Longitude } \\
\text { (deg. min. sec.) }\end{array}$ & $\begin{array}{c}\text { Albers } \\
\text { NAD83 } \\
\text { projection } \\
\text { easting } \\
\text { coordinate } \\
\text { (meters) }\end{array}$ & $\begin{array}{c}\text { Albers } \\
\text { NAD83 } \\
\text { projection } \\
\text { northing } \\
\text { coordinate } \\
\text { (meters) }\end{array}$ & $\begin{array}{c}\text { Elevation } \\
\text { (ft above } \\
\text { NAVD 88) }\end{array}$ \\
\hline \multicolumn{10}{|c|}{ Data source: Downsizer-Continued } \\
\hline Braman & 77 & OK & Kay & 341075 & $365518.84 \mathrm{~N}$ & $0972006.00 \mathrm{~W}$ & $-117,813.4$ & $1,542,832.8$ & 1,050 \\
\hline Bristow & 78 & OK & Creek & 341144 & $354945.12 \mathrm{~N}$ & $0962330.12 \mathrm{~W}$ & $-35,072.9$ & $1,419,684.4$ & 830 \\
\hline Broken Arrow 2 SW & 79 & $\mathrm{OK}$ & Tulsa & 341157 & $360159.88 \mathrm{~N}$ & $0954900.12 \mathrm{~W}$ & $16,368.7$ & $1,442,482.4$ & 689 \\
\hline Burbank & 80 & $\mathrm{OK}$ & Osage & 341256 & $364134.08 \mathrm{~N}$ & $0964354.84 \mathrm{~W}$ & $-64,789.2$ & $1,516,586.7$ & 974 \\
\hline Chelsea & $84 *$ & $\mathrm{OK}$ & Rogers & 341716 & $363159.88 \mathrm{~N}$ & $0952559.88 \mathrm{~W}$ & $50,272.1$ & $1,498,618.8$ & 722 \\
\hline Chelsea $4 \mathrm{~S}$ & $85^{*}$ & $\mathrm{OK}$ & Mayes & 341717 & $362850.16 \mathrm{~N}$ & $0952515.96 \mathrm{~W}$ & $51,390.3$ & $1,492,721.9$ & 735 \\
\hline Claremore 2 ENE & 86 & $\mathrm{OK}$ & Rogers & 341828 & $361921.00 \mathrm{~N}$ & $0953450.88 \mathrm{~W}$ & $37,291.6$ & $1,474,938.4$ & 587 \\
\hline Claremore $5 \mathrm{~W}$ & 87 & $\mathrm{OK}$ & Rogers & 341832 & $361825.92 \mathrm{~N}$ & $0954152.08 \mathrm{~W}$ & $26,888.9$ & $1,473,185.2$ & 538 \\
\hline Cleveland 1 & 88 & $\mathrm{OK}$ & Pawnee & 341891 & $361900.12 \mathrm{~N}$ & $0962800.12 \mathrm{~W}$ & $-41,520.3$ & $1,474,308.4$ & 801 \\
\hline Cleveland & 89 & $\mathrm{OK}$ & Pawnee & 341900 & $361800.00 \mathrm{~N}$ & $0962800.12 \mathrm{~W}$ & $-41,529.5$ & $1,472,437.9$ & 794 \\
\hline Cleveland 4 WSW & 90 & $\mathrm{OK}$ & Pawnee & 341902 & $361725.08 \mathrm{~N}$ & $0963212.84 \mathrm{~W}$ & $-47,782.3$ & $1,471,384.5$ & 919 \\
\hline Cleveland Lake & 91 & $\mathrm{OK}$ & Pawnee & 341903 & $361600.12 \mathrm{~N}$ & $0963459.88 \mathrm{~W}$ & $-51,928.0$ & $1,468,765.6$ & 781 \\
\hline Crescent & 92 & $\mathrm{OK}$ & Logan & 342242 & $355536.84 \mathrm{~N}$ & $0974027.12 \mathrm{~W}$ & $-149,708.3$ & $1,431,870.6$ & 1,073 \\
\hline Glencoe near SCS 6 & 98 & $\mathrm{OK}$ & Payne & 343558 & $361059.88 \mathrm{~N}$ & $0965400.00 \mathrm{~W}$ & $-80,209.8$ & $1,459,645.2$ & - \\
\hline Great Salt Plains Dam & $99 *$ & $\mathrm{OK}$ & Alfalfa & 343740 & $364433.00 \mathrm{~N}$ & $0980759.16 \mathrm{~W}$ & $-188,687.0$ & $1,524,023.0$ & 1,201 \\
\hline Guthrie Muni AP & 100 & $\mathrm{OK}$ & Logan & 343818 & $355106.12 \mathrm{~N}$ & $0972451.12 \mathrm{~W}$ & $-126,586.1$ & $1,423,073.3$ & 1,070 \\
\hline Guthrie & 101 & $\mathrm{OK}$ & Logan & 343821 & $354857.96 \mathrm{~N}$ & $0972342.00 \mathrm{~W}$ & $-124,926.1$ & $1,419,062.2$ & 1,109 \\
\hline Guthrie SCS & 102 & $\mathrm{OK}$ & Logan & 343830 & $354800.00 \mathrm{~N}$ & $0972500.12 \mathrm{~W}$ & $-126,896.1$ & $1,417,288.5$ & 981 \\
\hline Hallett $1 \mathrm{NW}$ & 103 & $\mathrm{OK}$ & Pawnee & 343862 & $361500.00 \mathrm{~N}$ & $0963600.00 \mathrm{~W}$ & $-53,426.5$ & $1,466,904.4$ & 942 \\
\hline Hardy 2 SSW & 104 & $\mathrm{OK}$ & Kay & 343909 & $365617.16 \mathrm{~N}$ & $0964917.04 \mathrm{~W}$ & $-72,474.1$ & $1,544,133.6$ & 1,106 \\
\hline Haskell & 105 & $\mathrm{OK}$ & Muskogee & 343956 & $354932.88 \mathrm{~N}$ & $0954135.88 \mathrm{~W}$ & $27,463.3$ & $1,419,275.7$ & 594 \\
\hline Helena $1 \mathrm{SSE}$ & 106 & $\mathrm{OK}$ & Alfalfa & 344019 & $363217.16 \mathrm{~N}$ & $0981557.96 \mathrm{~W}$ & $-200,995.6$ & $1,501,403.1$ & 1,352 \\
\hline Hennessey 4 ESE & 107 & $\mathrm{OK}$ & Kingfisher & 344055 & $360539.12 \mathrm{~N}$ & $0975006.00 \mathrm{~W}$ & $-163,723.7$ & $1,450,867.4$ & 1,175 \\
\hline Herd & 108 & $\mathrm{OK}$ & Osage & 344064 & $365200.12 \mathrm{~N}$ & $0961200.00 \mathrm{~W}$ & $-17,663.5$ & $1,535,839.1$ & 991 \\
\hline Heyburn Dam & 109 & OK & Creek & 344098 & $355700.00 \mathrm{~N}$ & $0961659.88 \mathrm{~W}$ & $-25,326.5$ & $1,433,176.3$ & 830 \\
\hline Hominy & 110 & $\mathrm{OK}$ & Osage & 344289 & $362411.16 \mathrm{~N}$ & $0962327.96 \mathrm{~W}$ & $-34,754.7$ & $1,483,955.7$ & 774 \\
\hline Hulah & 111 & OK & Osage & 344388 & $365559.88 \mathrm{~N}$ & $0960159.88 \mathrm{~W}$ & $-2,938.4$ & $1,543,283.1$ & 722 \\
\hline
\end{tabular}


Table 3. Climate stations with records used to develop daily precipitation and air-temperature inputs for the 0sage Nation watershed model (ONWM), Oklahoma and Kansas.—Continued

[deg., degrees; ft, feet; ID, identification; min., minutes; NAD83, North American horizontal Datum of 1983; NAVD 88, North American Vertical Datum of 1988; sec., seconds; - , data not available or not applicable]

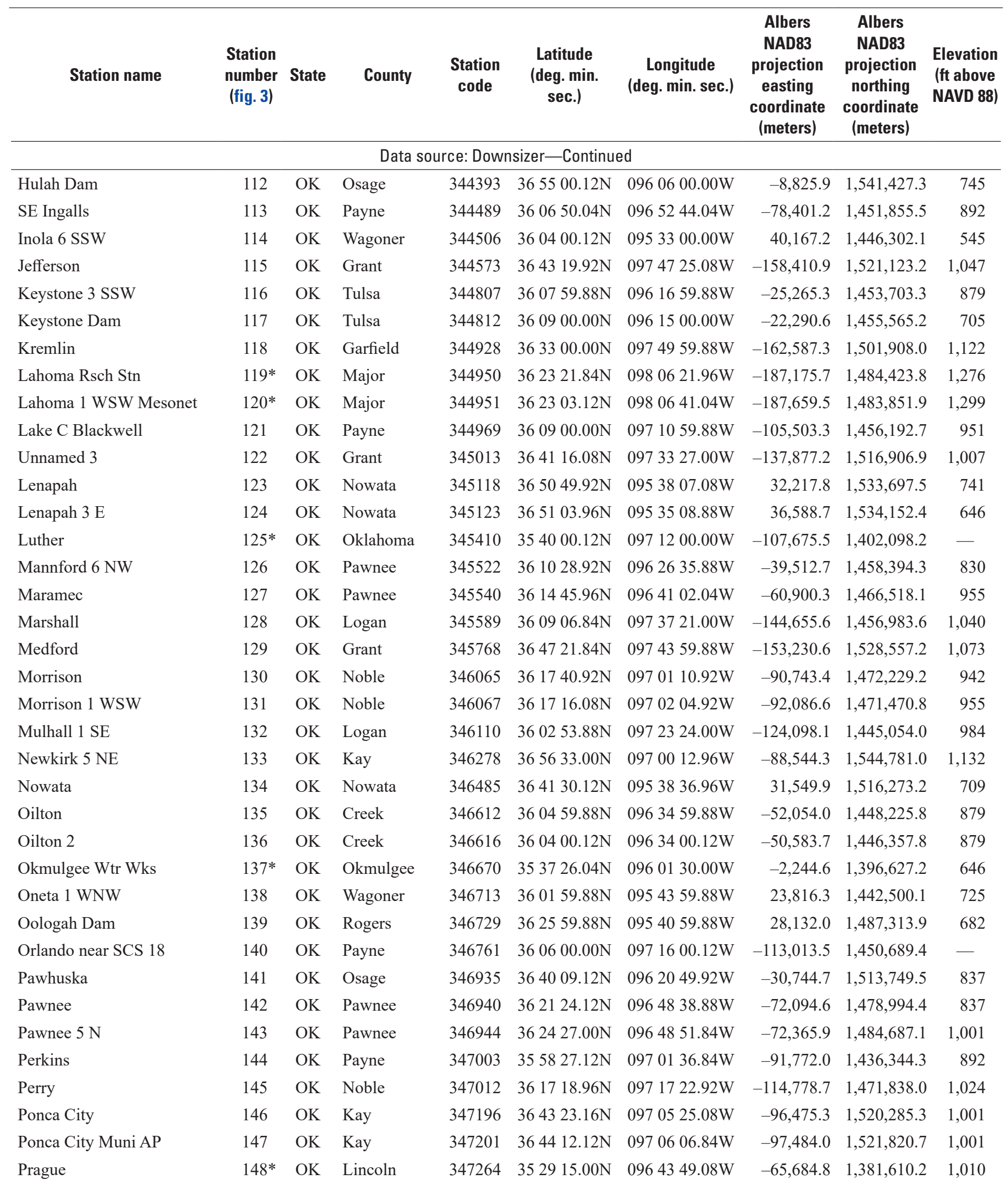


Table 3. Climate stations with records used to develop daily precipitation and air-temperature inputs for the Osage Nation watershed model (ONWM), Oklahoma and Kansas.-Continued

[deg., degrees; ft, feet; ID, identification; min., minutes; NAD83, North American horizontal Datum of 1983; NAVD 88, North American Vertical Datum of 1988; sec., seconds; - , data not available or not applicable]

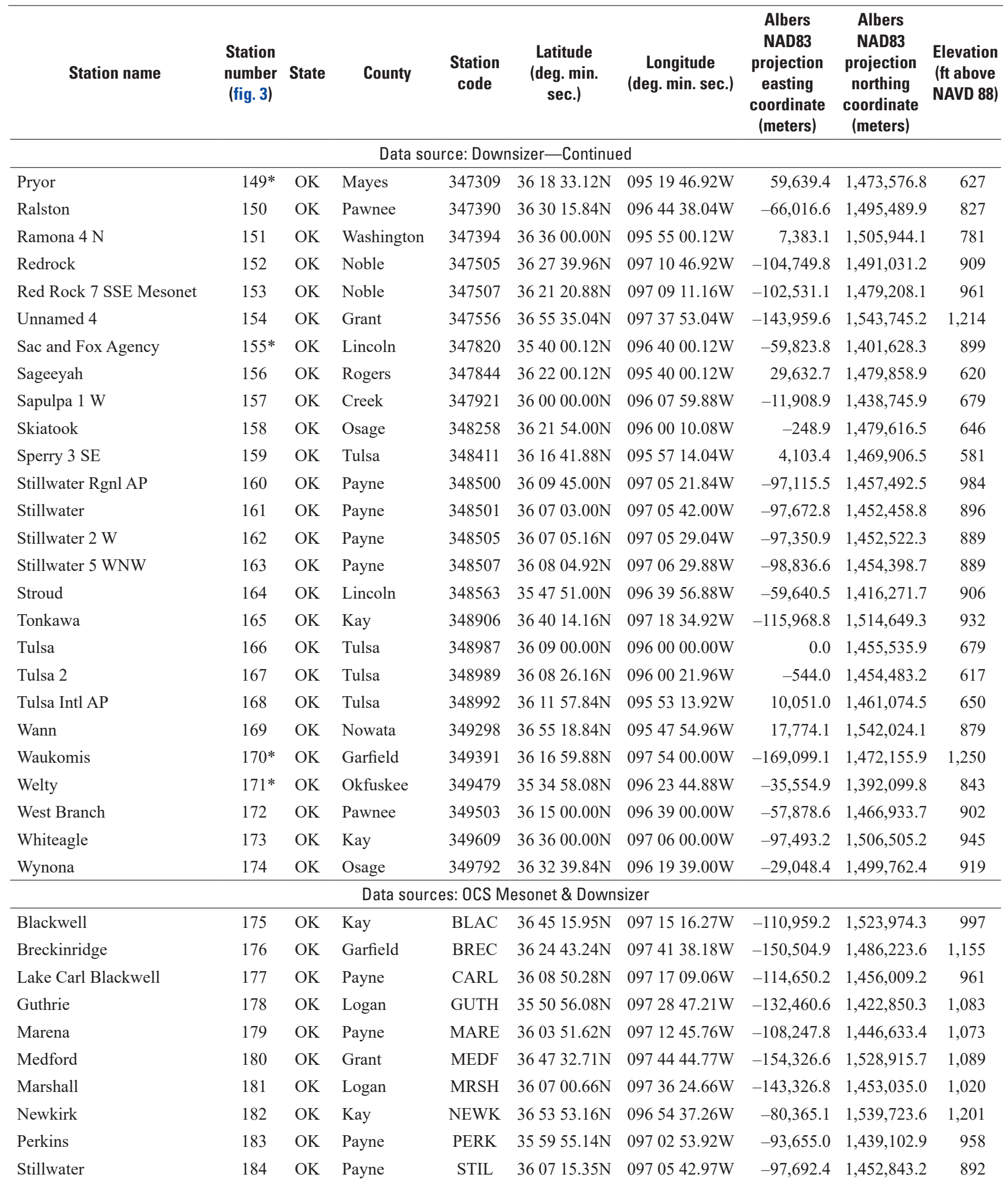


Table 3. Climate stations with records used to develop daily precipitation and air-temperature inputs for the 0sage Nation watershed model (ONWM), Oklahoma and Kansas.—Continued

[deg., degrees; ft, feet; ID, identification; min., minutes; NAD83, North American horizontal Datum of 1983; NAVD 88, North American Vertical Datum of 1988; sec., seconds; - , data not available or not applicable]

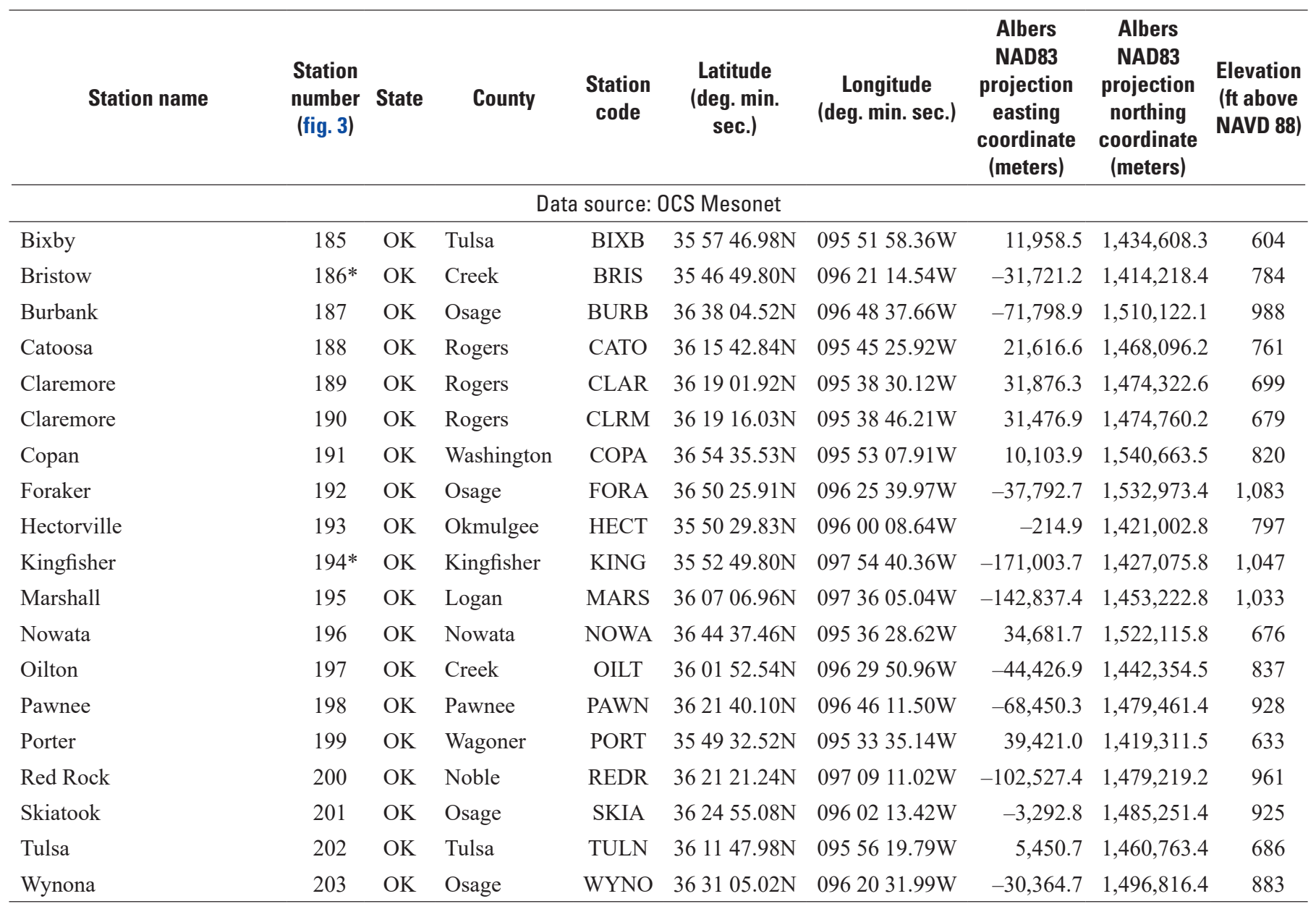

"Identifies stations outside of map area shown on figure 3.

Annual precipitation in the ONWM area varied from a maximum of 57.8 inches during water year 1999 to a minimum of 18.5 inches during water year 1956 (fig. 4A). Annual precipitation was about 50 inches or greater for 8 years, and 5 of these were after water year 1984. In contrast to the prevalence of wet years after 1984, annual precipitation was less than about 25 inches in 5 years prior to water year 1984 compared to only 2 years after 1984 . The locally weighted scatterplot smoothing (LOWESS) result indicated several wetter than average periods, including a prevalence of greater than average precipitation for water years 1985 to 1999 , with 50 inches or greater precipitation for water years 1985, 1993, and 1999 (fig. 4A). The period of least precipitation was in the drier than average years from water years 1952 through 1956.
The cumulative departure from the 100-year mean annual precipitation of 36.1 inches, calculated on the basis of water years, was used to define wet and dry periods and to identify possible climate cycles (fig. $4 B$ ). A positive slope in the cumulative departure line indicates a sequence of years when annual precipitation was greater than the 100-year mean; a negative slope indicates a sequence of years when annual precipitation was less than the 100-year mean; and a relatively flat line indicates a period when annual precipitation was similar to the 100-year mean. The wet, dry, and neutral periods indicated by the cumulative departure from mean annual precipitation were generally consistent with the wet and dry periods indicated by LOWESS. The cumulative departure indicated a long-term shift in annual precipitation around water year 1985. Mean annual precipitation for water years $1915-84$ was 35 inches, compared to 39 inches for water years 1985-2014. 

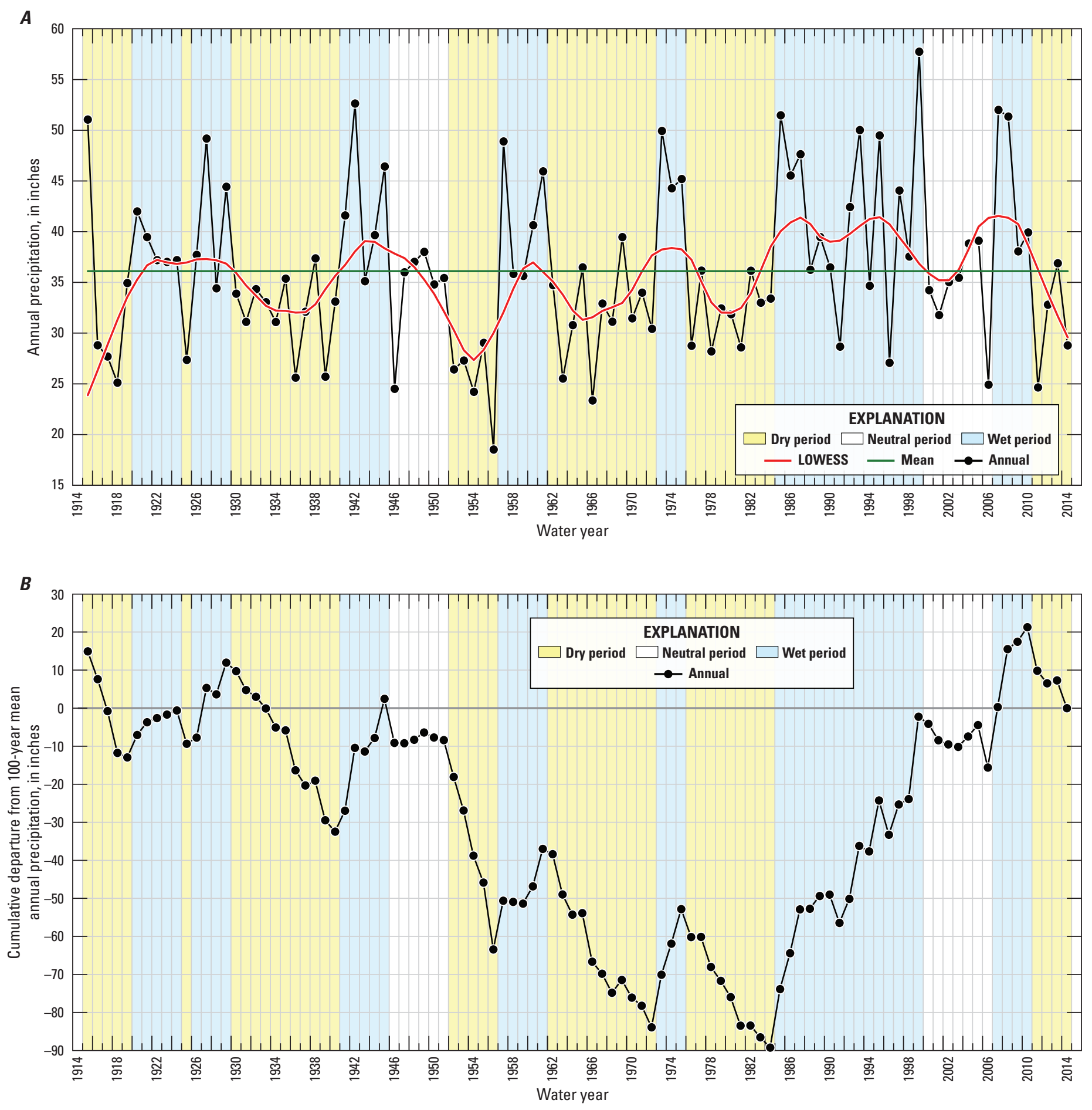

Figure 4. Annual precipitation for water years 1915-2014 in the Osage Nation watershed model (ONWM) area, Oklahoma and Kansas: $A$, annual total, averaged over the ONWM area, and $B$, cumulative departure from the 100 -year mean. 
Overall there were 55 dry years during which precipitation was less than the 100 -year mean, indicating that conditions were drier than average 55 percent of the time. The annual time series of precipitation for the Osage Nation indicated climate variability was likely influenced by periodicities coincident with the oscillations of several different circulation patterns that can affect climate cycles: the El Nino-Southern Oscillation (ENSO), 2-6 years; the North American Monsoon-Pineapple Express (NAMSPE), 7-10 years; the Pacific Decadal Oscillation (PDO), 10-30 years (Hanson and others, 2006); and the Atlantic Multidecadal Oscillation (AMO) cycle of about 65-70 years (Schlesinger, 1994). Most of the variation in precipitation, primarily variability in annual precipitation amounts, can be explained with the longer climate cycles. For the Osage Nation, these cycles are likely to be important for evaluating inter-decadal sustainability of the water resources (Hanson and others, 2004, 2006; Gurdak and others, 2009). Based on statistical inference from periodicities of known climate cycles and spectral frequency analysis of known climate cycles (Hanson and others, 2004, 2006; Dickinson and others, 2014), variability in annual precipitation and multi-year wet and dry periods is a response to a composite of climate cycles that largely represent a longer 50-year cycle. The longer cycle accounts for 70 percent of the historical variation and could be related to the AMO cycle. The remaining variation includes a 14-year cycle that accounts for an additional 19 percent of the total precipitation variation, combined with a 12.5 -year cycle that accounts for an additional 6 percent of the precipitation variation, and this variability likely is caused by the influence of the PDO (Hanson and others, 2004, 2006). There are also minor contributions of a 7-year cycle representing about 2 percent of the precipitation variation that is related to the influence of the NAMS-PE (Hanson and others, 2004, 2006), and the remaining 3 percent are 2-4 year cycles that represent the influences of the ENSO.

Mean monthly precipitation for water years 1915-2014 indicated May and June were the wettest months in the ONWM area, with a mean value close to 5 inches for both months (fig. 5). September was the third wettest month, at a mean of 4 inches of precipitation, resulting in a bimodal distribution of mean monthly precipitation, with peaks during the spring and late summer to early fall. January was the driest month, at a mean of only about 1.2 inches.

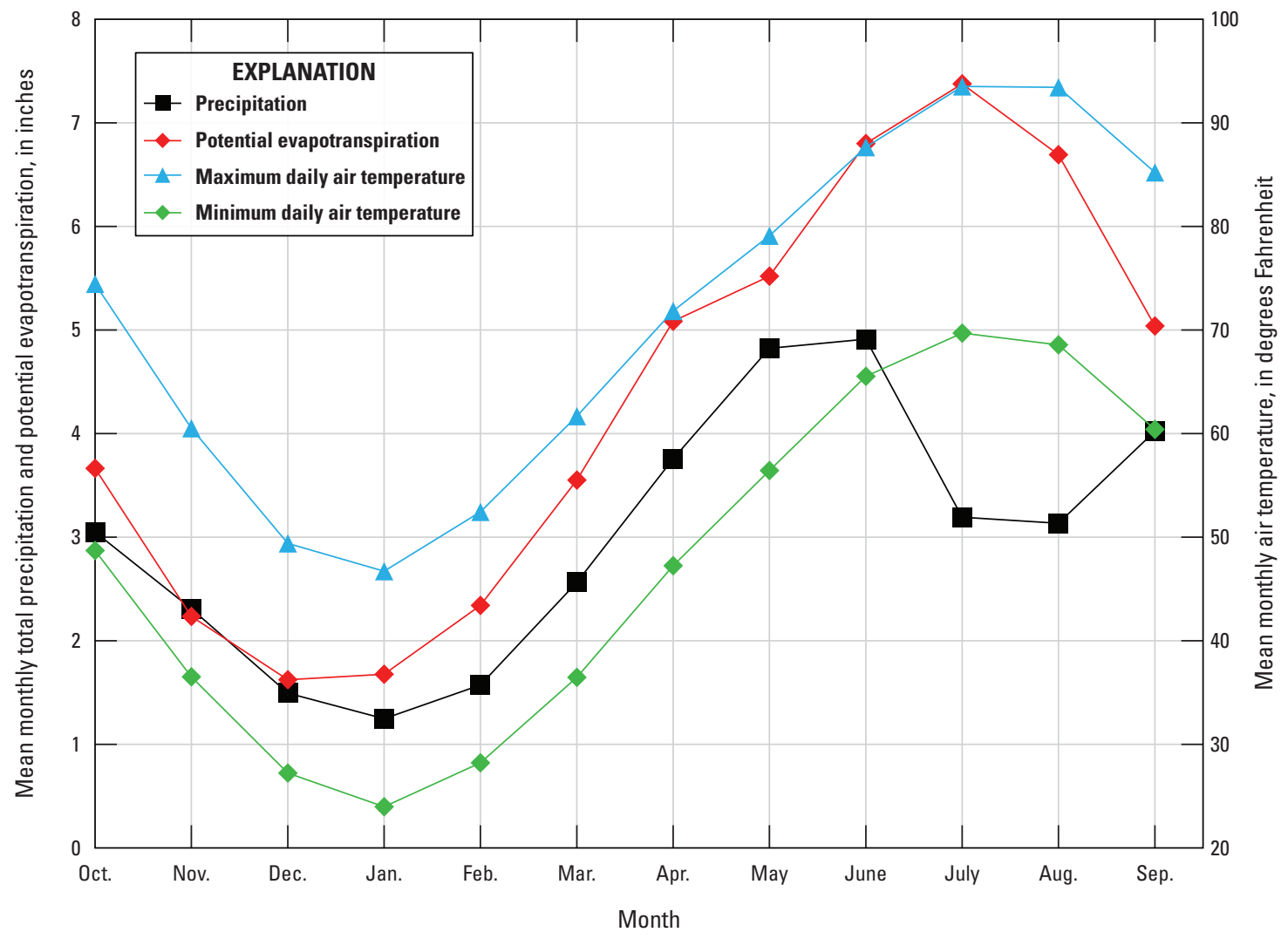

Figure 5. Mean monthly precipitation, maximum and minimum air temperatures, and potential evapotranspiration, water years 19152014, averaged for the area of the Osage Nation watershed model, Oklahoma and Kansas. 


\section{Air Temperature}

Following the method used to develop estimates of precipitation, daily maximum and minimum air temperatures were estimated for water years 1910-2014 for the ONWM area using spatial interpolation (Hevesi and others, 2011b; Flint and Martin, 2012; Woolfenden and Nishikawa, 2014; Hevesi and Christensen, 2015), daily records from 203 climate stations in and around the ONWM area (table 3; fig. 6), and grid-based maps of estimated 30-year normal (average) monthly maximum and minimum air temperatures for 19812010 as calculated by PRISM (Daly and others, 1994, 2004). As with daily precipitation records, daily air-temperature records for 184 of the 203 stations were obtained using the USGS Downsizer application (Ward-Garrison and others, 2009) and consisted primarily of records from the National Oceanic and Atmospheric Cooperative Observer Network (https://www.ncdc.noaa.gov/data-access/land-based-stationdata/land-based-datasets/cooperative-observer-networkcoop, accessed September 2015). Daily air-temperature records for 29 of the 203 stations were from the OCS Mesonet database (Oklahoma Climatological Survey, 2013; https://www.mesonet.org/, accessed September 2015). As with precipitation, OCS Mesonet air-temperature records for 10 of the 29 stations were supplemental to the Downsizer records obtained for those stations.

The mean air temperature for water years 1915-2014 for the ONWM area was 59.4 degrees Fahrenheit $\left({ }^{\circ} \mathrm{F}\right)$. Spatially interpolated mean maximum daily air temperature for the ONWM area was $71.4^{\circ} \mathrm{F}$, with a range in maximum values from $73^{\circ} \mathrm{F}$ along the southwestern boundary of the ONWM area and along the southwestern boundary of the Osage Nation to $68^{\circ} \mathrm{F}$ in the northern part of the ONWM area (fig. 6). Spatially interpolated mean minimum daily air temperature in the ONWM area was $47.4^{\circ} \mathrm{F}$, with a maximum of $50^{\circ} \mathrm{F}$ in several areas in the southern part of the ONWM area and a minimum of $44^{\circ} \mathrm{F}$ in northeastern part (fig. 7).
On an annual basis, mean daily air temperature in the ONWM area, calculated as the mean of the maximum and minimum daily air temperatures, varied from a maximum of $62.8^{\circ} \mathrm{F}$ for water year 1954 to a minimum of $56.6^{\circ} \mathrm{F}$ for water year 1979 (fig. 8A). As indicated by the LOWESS curve (fig. $8 A$ ) and by the cumulative departure from the 100-year mean daily air temperature (fig. $8 B$ ), annual mean air temperature tended to be higher than the 100 -year mean prior to water year 1958 and lower than the 100 -year mean from 1958 to 2014. The three lowest annual mean air temperatures of $57^{\circ} \mathrm{F}$ or less were all after water year 1958 . The lowest mean air temperature of $56.7^{\circ} \mathrm{F}$ was in water years 1979 and 2014, and the third lowest annual mean air temperature of $56.9^{\circ} \mathrm{F}$ was in water year 2003.

Mean monthly maximum daily air temperature varied from a low of about $48^{\circ} \mathrm{F}$ in January to a high of about $93^{\circ} \mathrm{F}$ in July and August (fig. 5). Mean monthly minimum daily air temperature varied from a low of $24^{\circ} \mathrm{F}$ in January to a high of $70^{\circ} \mathrm{F}$ in July. For all months, the difference between the mean maximum and minimum daily air temperature for water years 1915-2014 was between 20 and $25^{\circ} \mathrm{F}$.

\section{Simulated Snowfall}

In the ONWM, snowfall was simulated by PRMS as a function of precipitation, air temperature, and parameters defining the rain-snow mix based on air temperature and month. Mean annual snowfall for the ONWM, expressed as a water-equivalent depth, was 0.9 inch and ranged from a maximum of 1.4 inches along the northern boundary to a minimum of 0.7 inch in the western and southern areas of the ONWM (fig. 9). Assuming a snow density of 10 percent, a mean annual snowfall depth of about 9 inches was calculated for the ONWM area, which was consistent with the approximate 10 inches of mean annual snowfall reported by the Oklahoma Climatological Society for northern Oklahoma (http://climate.ok.gov/index.php/climate/ county_climate_by_county/osage). 


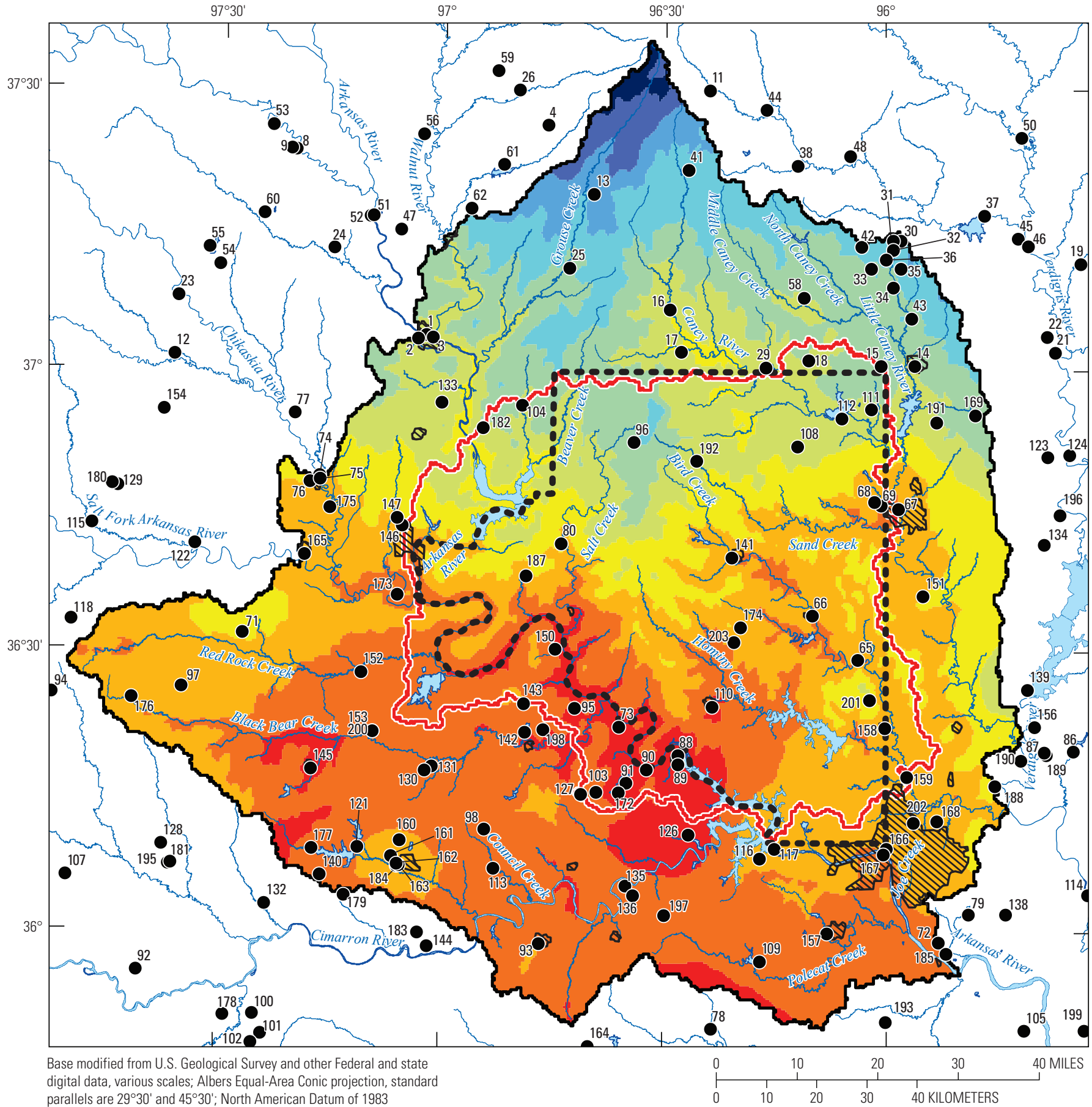

parallels are $29^{\circ} 30^{\prime}$ and $45^{\circ} 30^{\prime}$; North American Datum of 1983

\section{EXPLANATION}

\begin{tabular}{|c|c|}
\hline $68.1-68.5$ & $70.6-71.0$ \\
\hline $68.6-69.0$ & 71.1-71 \\
\hline $69.1-69.5$ & 71.6-72 \\
\hline $69.6-70.0$ & 72.1-72 \\
\hline $70.1-70.5$ & $72.6-7$ \\
\hline
\end{tabular}

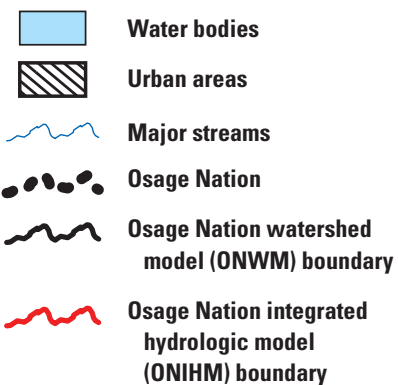

105 Climate station and identification (see table 3 for details)

Figure 6. Spatial distribution of mean maximum daily air temperature estimated for water years 1915-2014 for the Osage Nation Watershed Model area, Oklahoma and Kansas. 


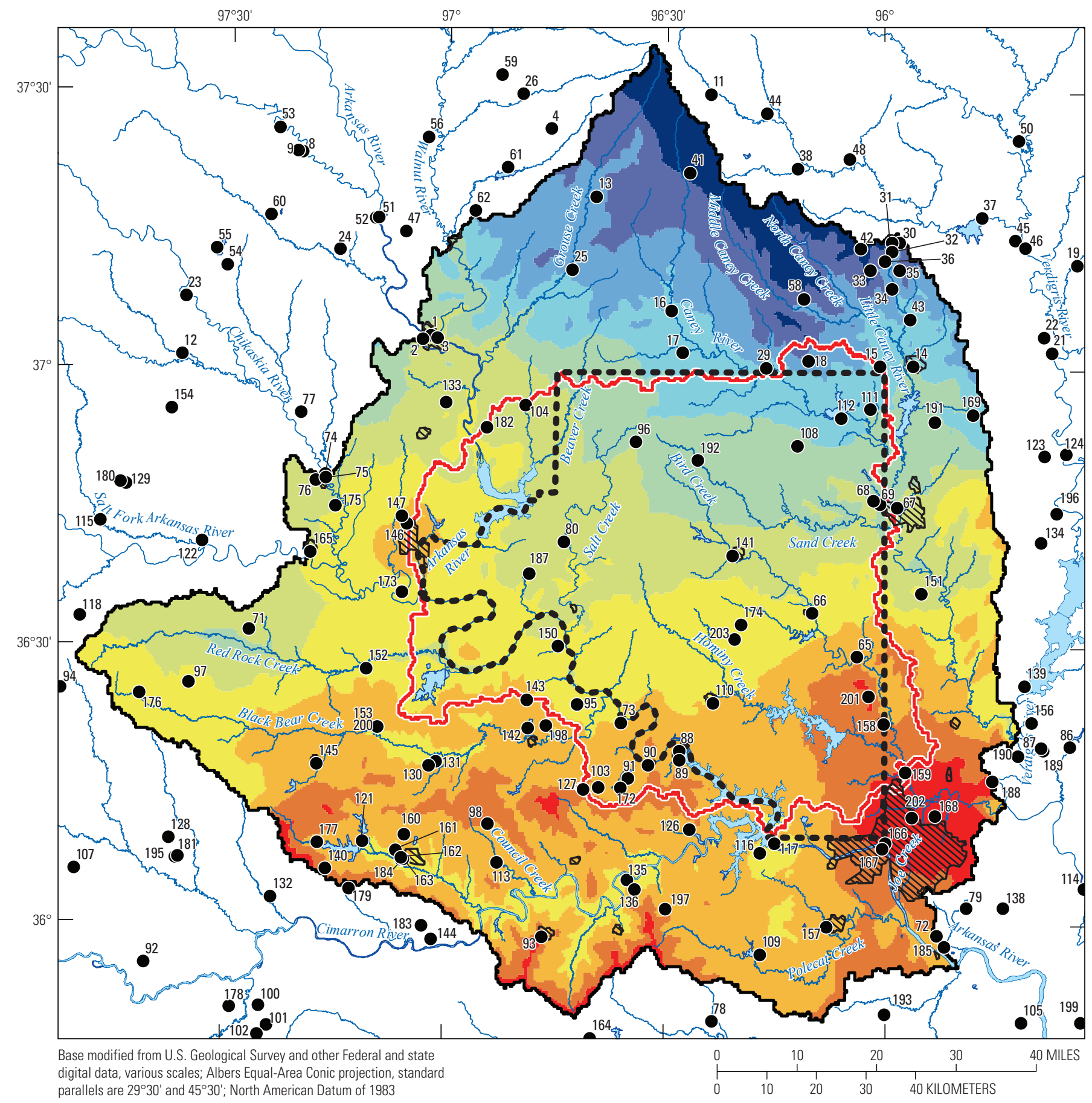

parallels are 29 $30^{\prime}$ and $45^{\circ} 30^{\prime}$; North American Datum of 1983

EXPLANATION

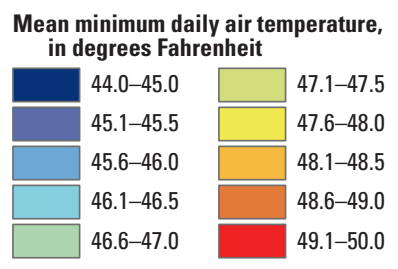

- Osage Nation
Water bodies

Urban areas

Major streams

nation watershed model (ONWM) boundary

Nosage Nation integrated

hydrologic model (ONIHM) boundary

Figure 7. Spatially distributed mean minimum daily air temperature estimated for water years 1915-2014 for the 0sage Nation watershed model area, Oklahoma and Kansas. 

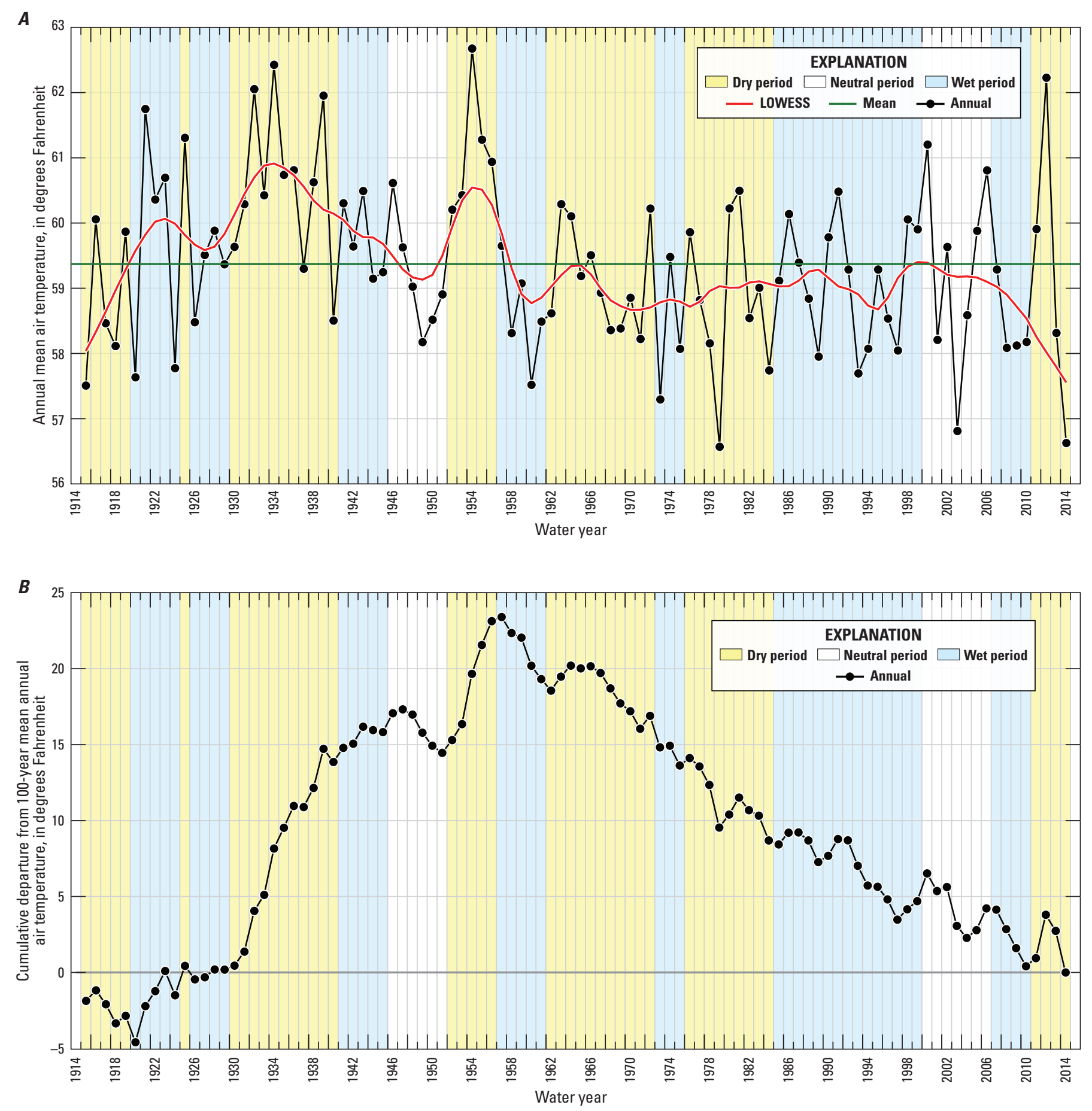

Figure 8. Air temperature for water years 1915-2014 in the Osage Nation watershed model area, Oklahoma and Kansas: $A$, annual mean, and $B$, cumulative departure from the 100-year mean. 


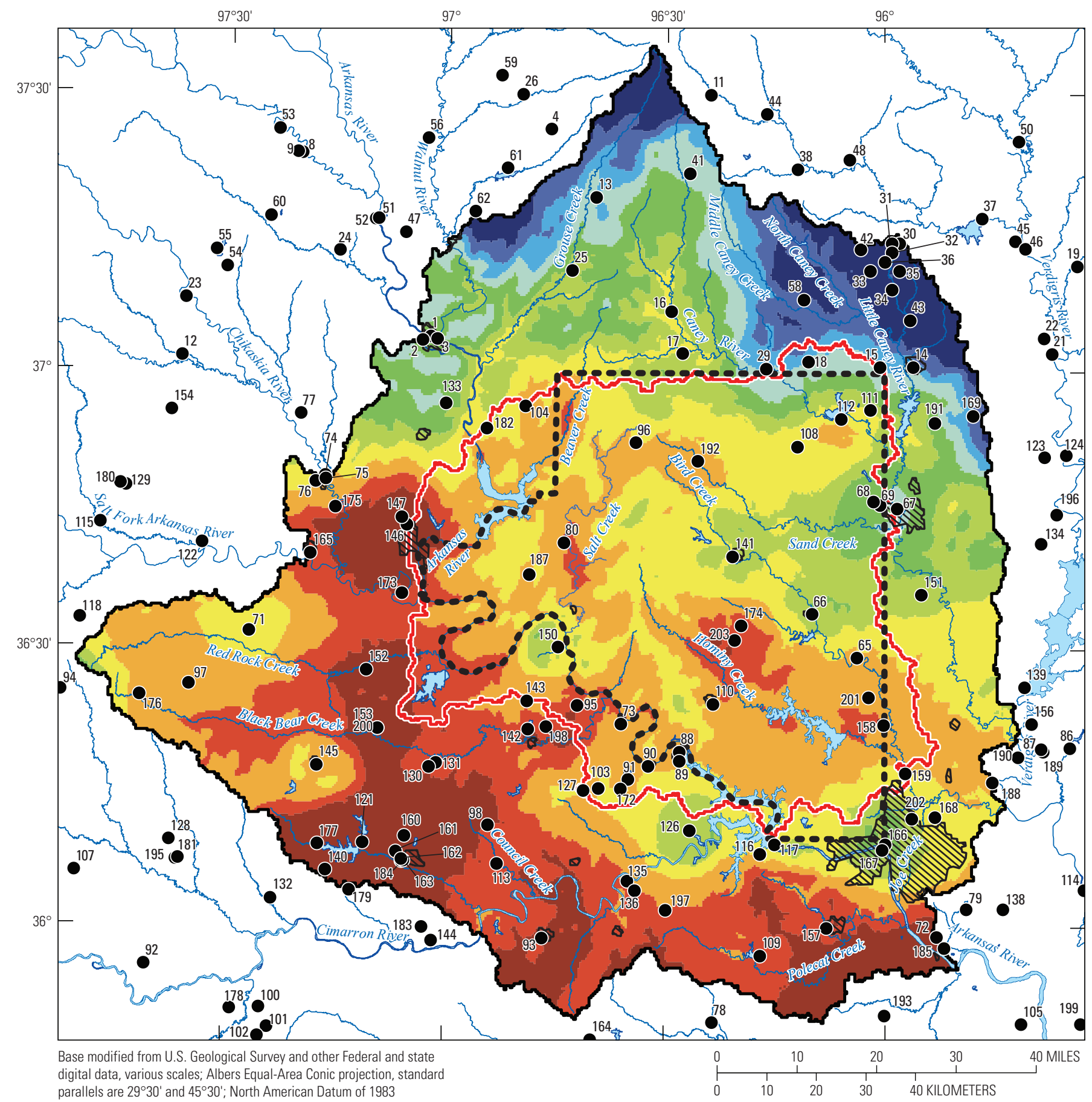

parallels are $29^{\circ} 30^{\prime}$ and $45^{\circ} 30^{\prime}$; North American Datum of 1983

EXPLANATION

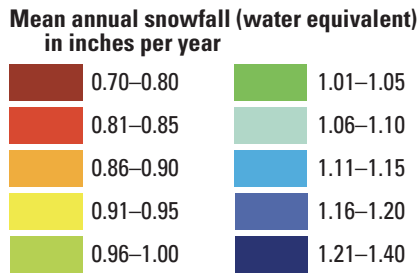

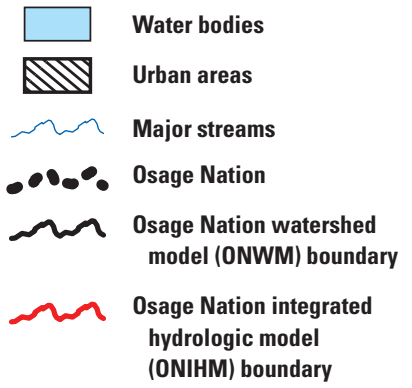

105 Climate station and identification (see table 3 for details)

(ONIHM) boundary

Figure 9. Spatially distributed mean annual snowfall estimated for water years 1915-2014 for the 0sage Nation watershed model area, Oklahoma and Kansas. 


\section{Physiography and Land Cover}

The region of the ONWM area, the ONIHM area, and the Osage Nation is in the Osage Plains section of the Central Lowland physiographic province (Fenneman and Johnson, 1946), a section characterized by a low-relief plain punctuated by east-facing escarpments formed by cuestas. Based on the National Elevation Dataset (NED; U.S. Geological Survey, 2016), the mean land-surface elevation in the ONWM area is 998 feet (ft) above North American Vertical Datum of 1988 (NAVD 88), and elevation ranges from a minimum of $496 \mathrm{ft}$ at the outflow of the Arkansas River near Tulsa to a maximum of $1,681 \mathrm{ft}$ in the northernmost part of the ONWM area (fig. 1A). Land-surface slope was calculated in a geographic information system (GIS) using the land-surface elevation data and is generally greatest for the valley side slopes along the main river valleys and the east-facing escarpments (fig. 10). Areas with relatively higher mean slopes, at least 11 percent (rise over run), are more prevalent in the eastern part of the Osage Nation and the ONIHM area. These areas tend to have deeper incised canyons and valleys with steeper slopes compared to the western side of the ONWM area.

The 2011 National Land Cover Dataset (NLCD; U.S. Geological Survey, 2011) includes land-cover classifications available as a raster-format national map with a grid resolution of approximately 98 by $98 \mathrm{ft}$ ( 0.22 acres). The NLCD land-cover data were resampled over a gridcell resolution of $1,312.3$ by $1,312.3 \mathrm{ft}$ (39.54 acres) for the ONWM area (fig. 11). The results indicated that land cover in the ONWM area is primarily natural vegetation, with about 51 percent of the land cover consisting of grasslands and about 18 percent consisting of deciduous forest (fig. 11; table 4). Open savannah-type grasslands dominate the northern, central, and south-central parts of the ONWM area, consisting primarily of mixed-grass prairie in the west transitioning to mixed tallgrass savannahs and woodlands to the east (Andrews and Smith, 2014). Open oak and hickory woodlands are more dominant in the eastern and southeastern parts of the ONWM area, which is characteristic of vegetation in the cross-timbers ecoregion (Omernik, 1987). Developed and agricultural lands cover 29 percent of the ONWM area, consisting primarily of cultivated crops (14 percent of total land cover) and pasture and hay (11 percent of total land cover combined). Areas of cultivated crops are dominant in the western part of the ONWM and are mostly outside of the Osage Nation and the ONIHM area (fig. 11). Most areas with pasture and hay land cover are along the eastern side of the ONWM and are outside of the Osage Nation and the ONIHM area. Developed land is centered on the urban areas and accounts for only 4 percent of total land cover, with open space and low-intensity developed land accounting for 3 percent of total land cover. Most of the developed land is in the Tulsa metropolitan area, in the southeastern part of the ONWM area, and is outside of the
Osage Nation and the ONIHM area. According to the NLCD 2011 data, open water covers about 2 percent of the land area in the ONWM area and includes the Arkansas River and impounded lakes, such as Kaw, Hulah, Bluestem, Birch, Keystone, Skiatook, and Sooner Lakes (fig. 1A).

The 2011 NLCD includes estimates of the fraction of developed impervious land surfaces, such as roadways, parking lots, and rooftops, covering each 0.22 -acre grid cell of the raster-based national map. Although the NLCD impervious-area fraction does not represent natural land cover where permeability is low, such as areas of exposed lowpermeability bedrock, the percentage of land area covered by developed, impervious surfaces is an important characteristic of a drainage basin and is useful for hydrologic modeling purposes. Snowmelt, rainfall, and surface runoff from upstream areas onto impervious surfaces cannot infiltrate the underlying soil, but rather contribute directly to surface runoff, with only a small amount contributing to surface-retention storage and evaporation.

The 2011 NLCD percentage of impervious-area estimates were resampled and averaged for the 39.54-acre grid cells used for the ONWM study area (fig. 12). The resampled results indicated that impervious surfaces cover 1.8 percent of the total ONWM land area. Areas with more than 20 percent of impervious land cover in each 39.54-acre cell are in the larger urban centers, including the cities of Tulsa, along the southeastern boundary of the ONWM; Ponca City, along the western boundary of the Osage Nation and the ONIHM area; Bartlesville, along the eastern boundary of the ONIHM area; and Pawhuska, in the central part of the Osage Nation (fig. 12). The maximum percentage of impervious land cover, 96 percent, is in the central part of the Tulsa metropolitan area. For rural areas outside of the urban centers, the percentage of impervious area is approximately zero for most locations, with the exception of about 2- to 5-percent impervious area associated with roadways and major transportation corridors (figs. 1, 12).

The 2011 NLCD national map also includes estimates of the percentage of each 0.22-acre raster cell covered by forest canopy. Similar to the percentage of developed impervious area, the percentage of land area covered by forest canopy is also an important land-cover characteristic for hydrologic modeling purposes. A fraction of the rain and snow falling over the ONWM area does not reach the ground surface, but instead is intercepted by the vegetation canopy, where it is stored and evaporated. The NLCD map showing the percentage of forest-canopy cover generally provides an indication of the more densely forested areas that have a greater potential storage capacity for intercepted rain and snow. The percentage of forest-canopy cover does not provide an indication of the interception-storage capacity for shrubland, grassland, and developed lands, including agricultural and urban areas. 


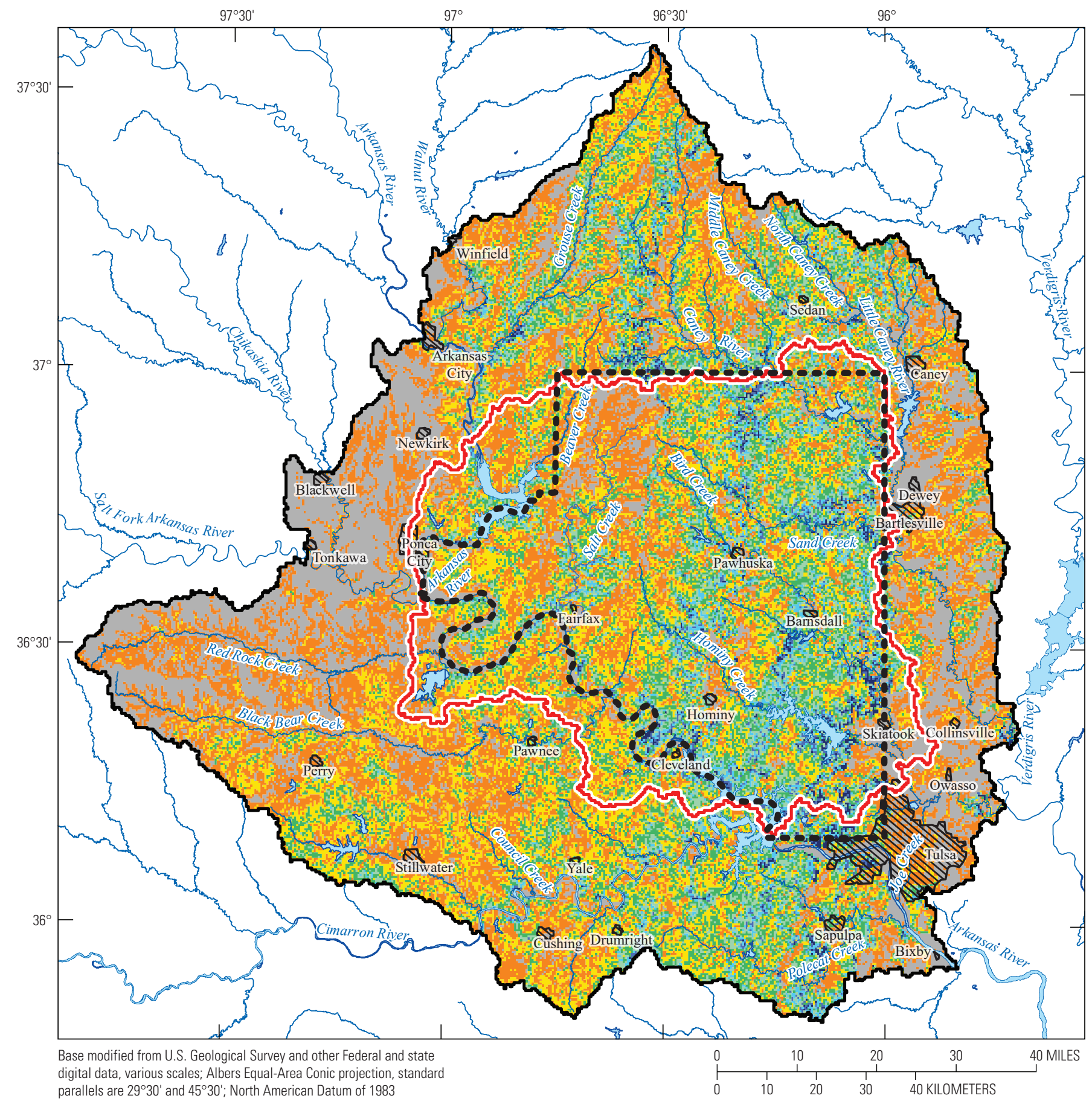

EXPLANATION

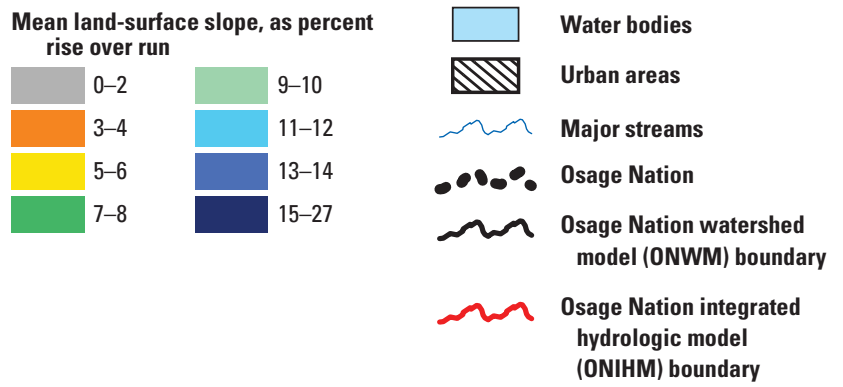

Figure 10. Mean land-surface slope in the Osage Nation watershed model area, Oklahoma and Kansas. 


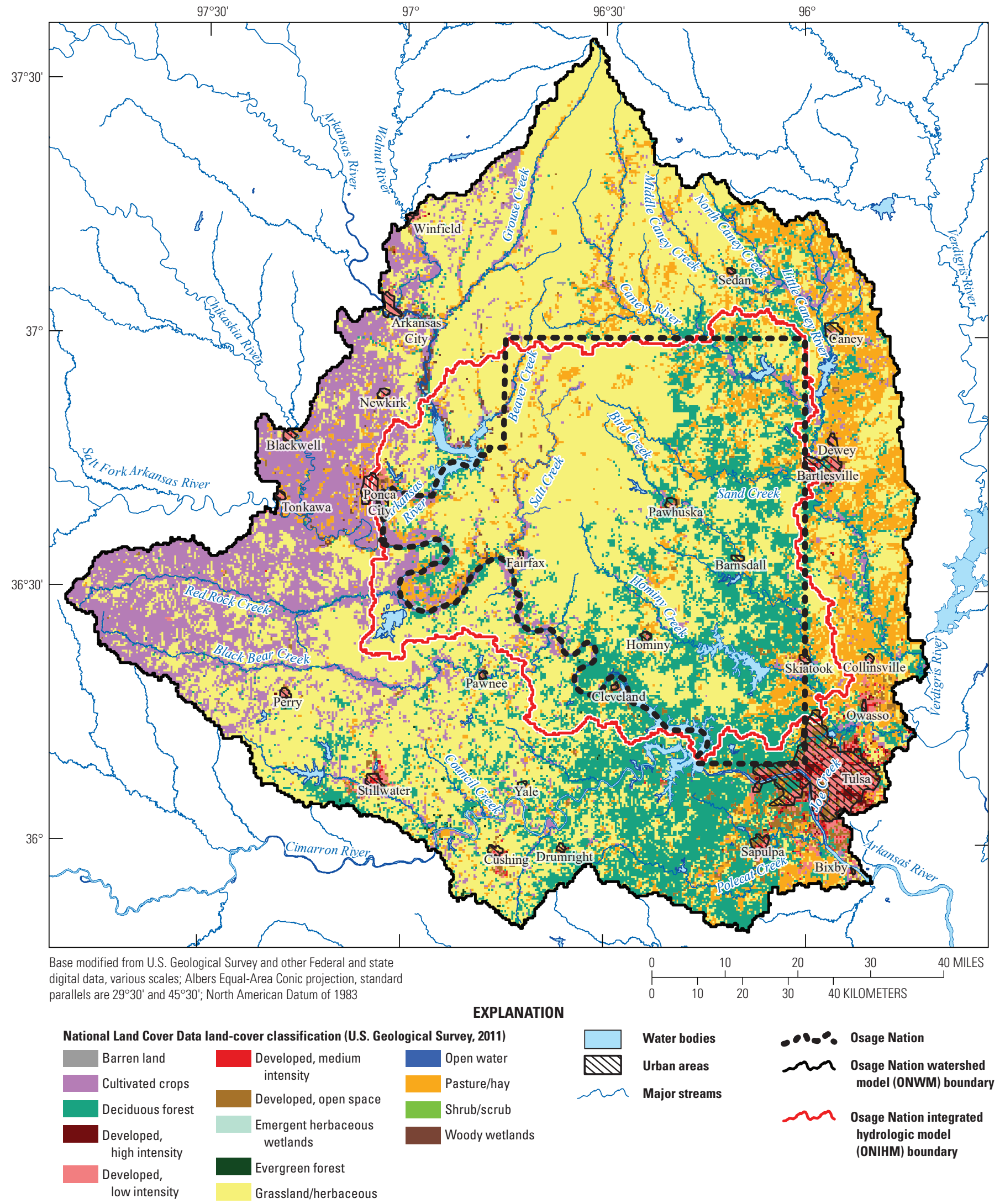

Figure 11. Land-cover classifications in the Osage Nation watershed model area, Oklahoma and Kansas. 
Table 4. Land-cover areas for the Osage Nation watershed model (ONWM), Oklahoma and Kansas.

[Data from U.S. Geological Survey, 2011]

\begin{tabular}{lrrr}
\hline \multicolumn{1}{c}{ Land cover } & $\begin{array}{c}\text { Area } \\
\text { (square } \\
\text { mile) }\end{array}$ & $\begin{array}{c}\text { Area } \\
\text { (acres) }\end{array}$ & $\begin{array}{c}\text { Percent } \\
\text { of ONWM } \\
\text { area }\end{array}$ \\
\hline Grassland/herbaceous & 4,220 & $2,701,000$ & 50.58 \\
Deciduous forest & 1,486 & 951,200 & 17.82 \\
Cultivated crops & 1,137 & 727,600 & 13.63 \\
Pasture/hay & 938 & 600,200 & 11.24 \\
Open Water & 174 & 111,300 & 2.08 \\
Developed, low intensity & 133 & 84,890 & 1.59 \\
Developed, open space & 129 & 82,320 & 1.54 \\
Woody wetlands & 40 & 25,620 & 0.48 \\
Developed, medium intensity & 33 & 21,030 & 0.39 \\
Developed, high intensity & 29 & 18,540 & 0.35 \\
Emergent herbaceous wetlands & 14 & 9,252 & 0.17 \\
Evergreen forest & 5 & 3,361 & 0.06 \\
Barren land & 4 & 2,768 & 0.05 \\
Shrub/scrub & 1 & 554 & 0.01 \\
\hline
\end{tabular}

The 2011 NLCD percentage of forest-canopy cover estimates were resampled and averaged for the 39.54-acre grid cells used for the ONWM study area (fig. 13). The resampled results indicated that the ONWM area has an average forestcanopy cover of 13 percent. A maximum of 93 percent of forest-canopy cover was indicated for riparian forest land along the Arkansas River (figs. 11, 13). Forest-canopy cover of 50 percent or greater was associated with land cover classified as forest (deciduous, evergreen, or mixed forest). Forestcanopy cover was generally greatest along the major rivers and creeks, which is characteristic of the densely vegetated riparian areas (figs. 11, 13). 


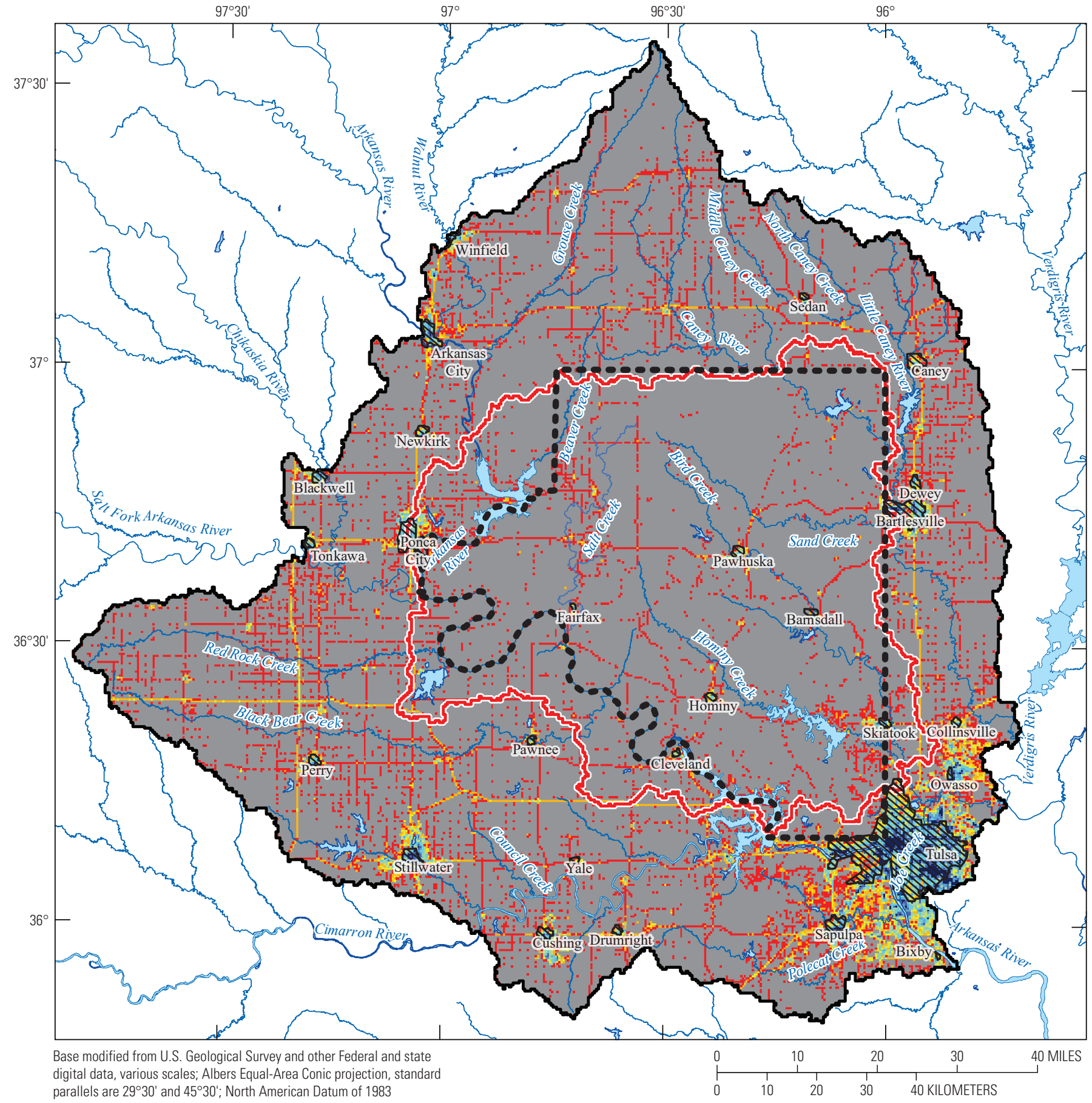

parallels are $29^{\circ} 30^{\prime}$ and $45^{\circ} 30^{\prime}$; North American Datum of 1983

EXPLANATION
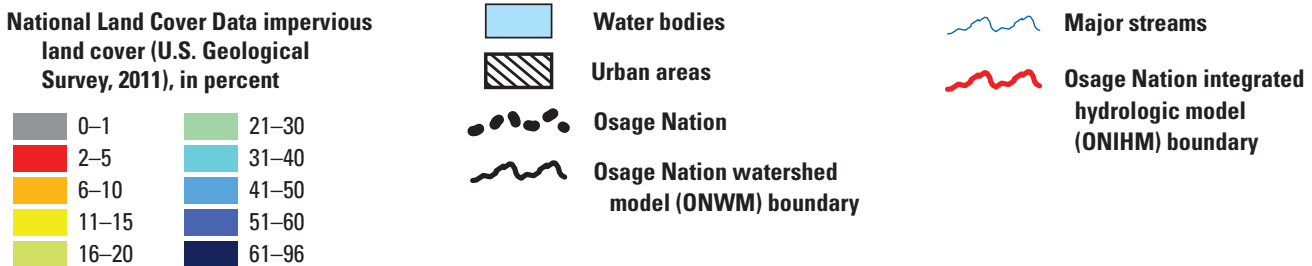

hydrologic model

Figure 12. Percentage of impervious land cover in the Osage Nation watershed model area, Oklahoma and Kansas. 


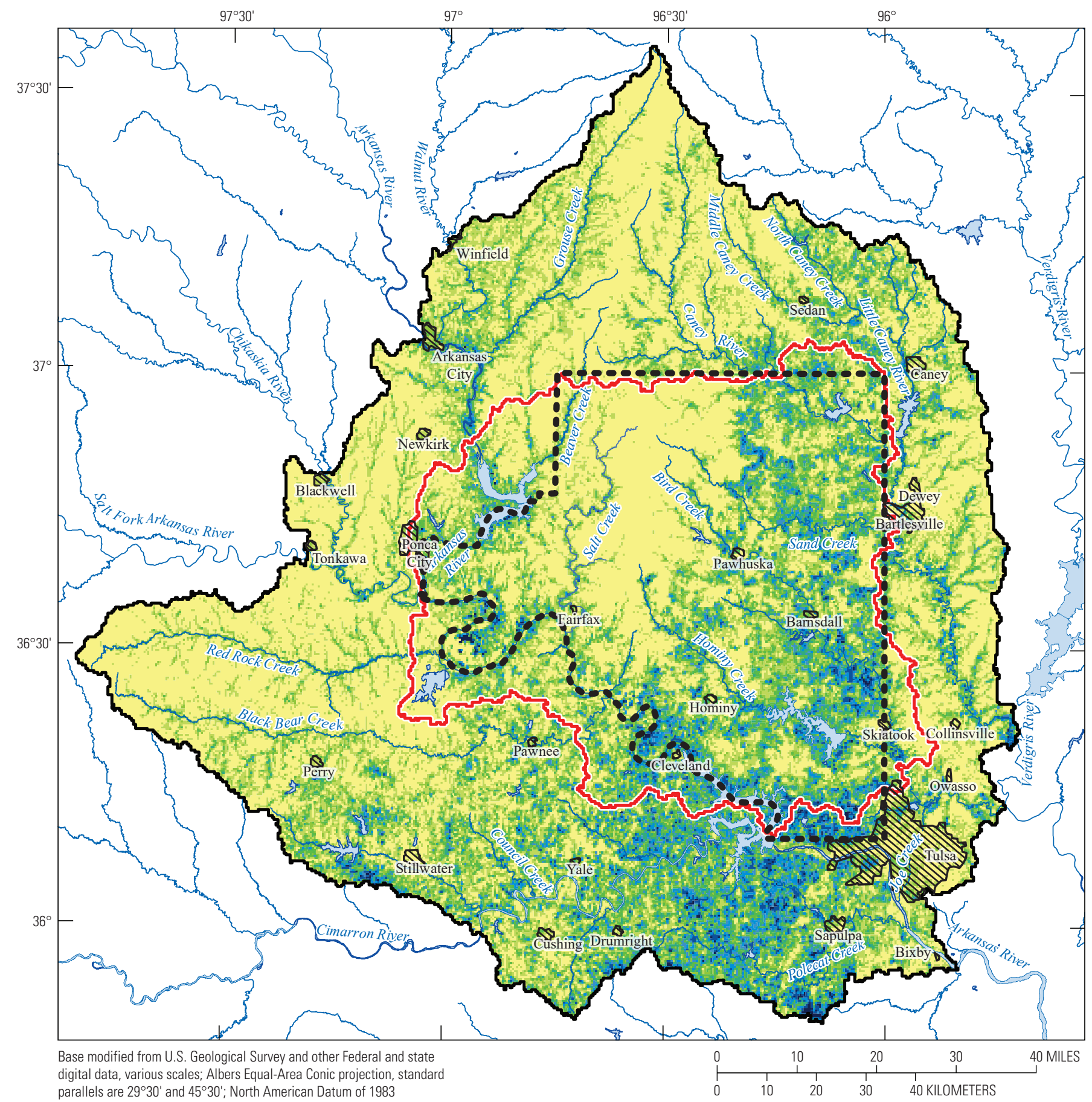

EXPLANATION
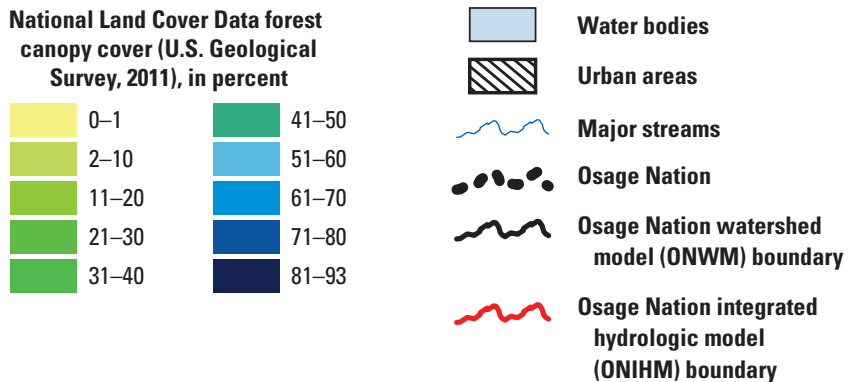

Figure 13. Percentage of forest-canopy cover in the Osage Nation watershed model area, Oklahoma and Kansas. 


\section{Soils}

Soils in the ONWM area are mixed, thermic, ustic to udic mollisols and alfisols (Shields, 1993), indicating soils are dry to wet prairie and forest soils formed under relatively high soil temperatures (between 59 and $72^{\circ} \mathrm{F}$ ) containing a relatively large amount of organic-matter for a mineral soil (Andrews and Smith, 2014). According to the Natural Resources Conservation Service (2006) and Bourlier and others (1979), three primary types of soils are in the Osage Nation and surrounding region: (1) deep loamy and sandy soils on wooded flood plains, (2) deep to shallow loamy soils on prairie uplands, and (3) deep to shallow loamy and sandy soils on wooded uplands. The soil associations composing these three general types are sandy to loamy, deep to moderately deep, well-drained to somewhat poorly drained, nearly level to steeply sloping soils underlying open prairies in the western one-third of the Osage Nation and surrounding region and underlying stream valleys and uplands in the eastern twothirds of the area (Bourlier and others, 1979). Such soils are likely to be permeable in most areas, facilitating recharge of precipitation to aquifers (Andrews and Smith, 2014).

The western part of the Osage Nation and the ONWM area is underlain by prairie soils (mollisols) associated with native tallgrass prairie that once spanned from eastern Texas northward into southern Canada and eastward through Iowa and the northern half of Illinois (Madsen and Oberle, 1993). The tallgrass prairie was a very diverse grassland ecosystem dominated by grasses and forbs growing between 5 and $10 \mathrm{ft}$ tall, where encroachment by woody plants was controlled by natural fire cycles and grazing by American bison (Cushman, 2004).

Soil characteristics, such as the vertical hydraulic conductivity and the storage capacity in the root zone, are important factors affecting surface runoff generation, ET, interflow, and recharge in response to rainfall, snowmelt, and inflows of surface runoff and interflow from upstream areas. The greater the vertical hydraulic conductivity, the higher the fraction of rain and snowmelt infiltrating the soil and the lower the fraction contributing to surface runoff when the soil is not fully saturated. The greater the soil storage capacity in the root zone, the greater the potential for infiltrated water to be stored in the root zone and contribute to ET rather than surface runoff, interflow, or recharge.

The mean vertical soil hydraulic conductivity for the ONWM area, estimated using the Soil Survey Geographic database (SSURGO; https://sdmdataaccess.sc.egov.usda.gov,
Sept. 15, 2015), is 7 inches per hour (in/hr) and ranges from near 0 to about $92 \mathrm{in} / \mathrm{hr}$ in the ONWM area (fig. 14). The vertical hydraulic conductivity tends to be greatest in many of the channel and valley bottoms, where the soils have a greater percentage of sand and coarser texture compared with soils in upland areas (fig. 14). Hydraulic conductivity is also greater in the central and south-central parts of the ONWM area where the soils tend to have a greater percentage of sand compared with the northern and western parts of the ONWM area. In many areas of the ONWM, soil hydraulic conductivity has a high degree of spatial variability on a local scale, ranging from 1 to $64 \mathrm{in} / \mathrm{hr}$. For example, areas in the North Caney Creek and Little Caney River valleys in the northeastern part of the ONWM area have soils in the valley bottoms with low conductivity and soils in the upland areas with high conductivity (fig. 14) because the valley bottoms and stream channels have clayey soils rather than sandy, coarse-textured soils. For the purpose of this study, areas defined by SSURGO as having undefined soil hydraulic conductivity, such as water bodies, were assigned a hydraulic conductivity value of zero.

The soil water content at field capacity (WCFC), measured at a pressure of one-third bar, is often used to represent the approximate water-content limit below which gravity drainage from the soil profile becomes minimal. Conceptually, the WCFC provides an indication of the maximum soil water content generally available for plant transpiration, whereas soil water content greater than the WCFC includes water available for recharge and interflow in addition to ET. The mean WCFC in the ONWM area, estimated using SSURGO and expressed as a percentage of the total soil volume, is 27 percent and ranges from 0 to 39 percent, with 0 percent used to represent water bodies for the purposes of this study (fig. 15). The higher values, 31 percent and greater, are common in the western and eastern parts of the ONWM area and indicate soils with a higher clay content relative to the central and southern parts of the ONWM area, including the eastern and southern parts of the Osage Nation and the ONIHM area. Lower WCFC values, 19 percent and less, generally correspond to areas with sandier and coarser grained soils associated with steeper slopes and valleys in the eastern and southern parts of the Osage Nation. Lower WCFC values also tend to be associated with the alluvial valley fill of the main river channels, such as the Arkansas and Cimarron Rivers. In addition, lower WCFC values are associated with urban areas, such as the Tulsa metropolitan area. 


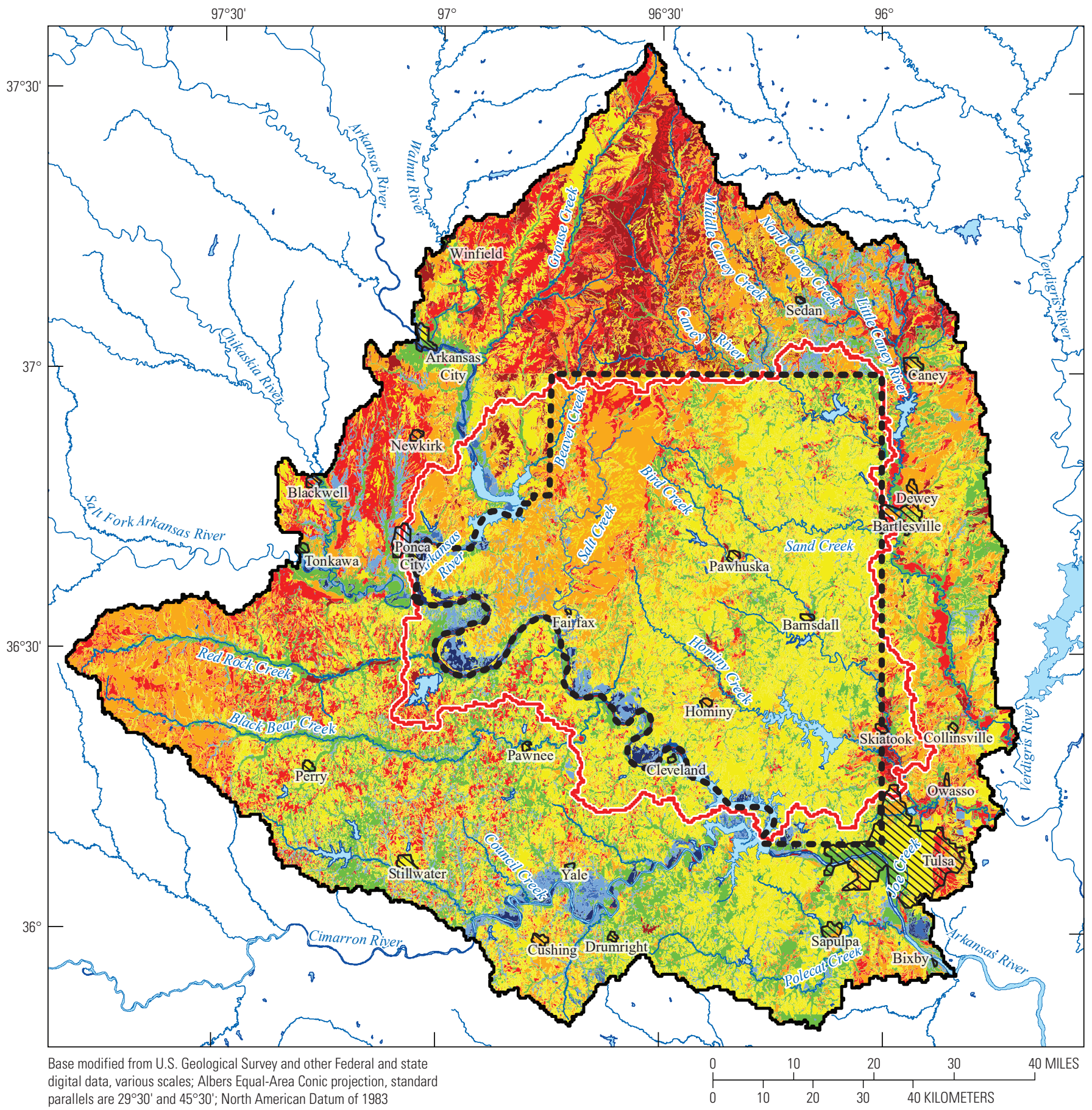

various scales; Albers Equal-Area Conic projection, standard

EXPLANATION

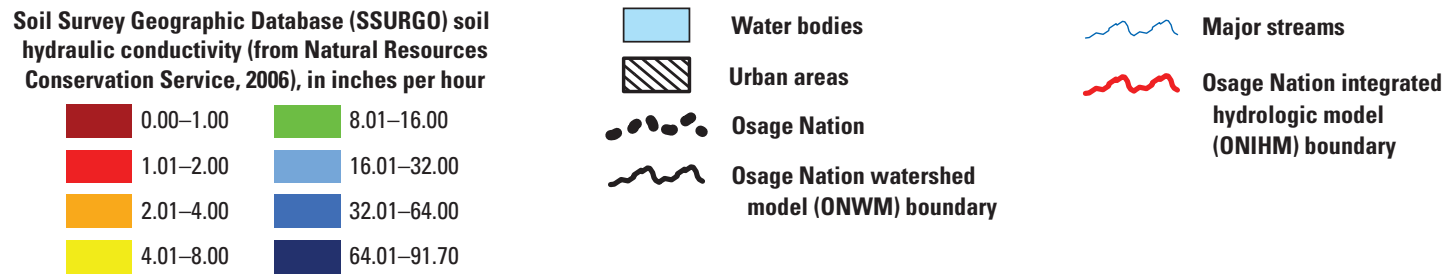

Figure 14. Vertical soil hydraulic conductivity, estimated using the the Soil Survey Geographic database, in the Osage Nation watershed model area, Oklahoma and Kansas. 


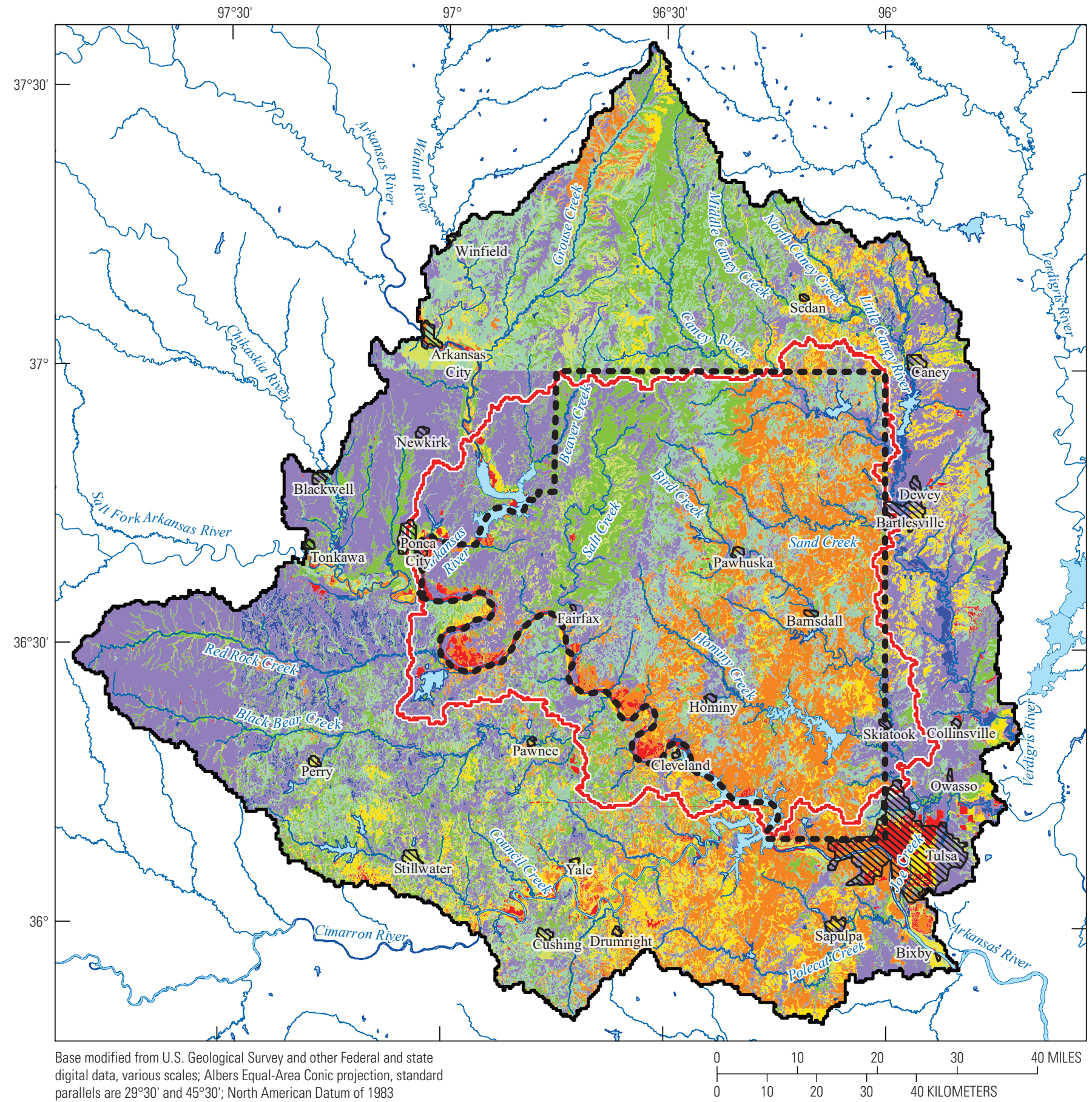

EXPLANATION
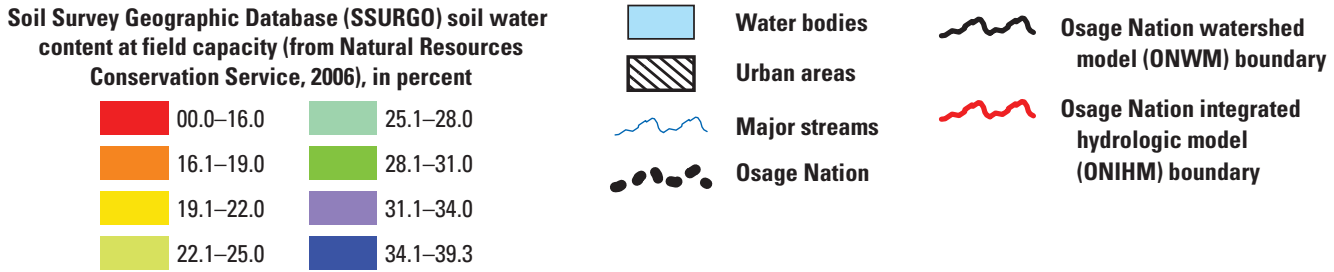

Figure 15. Soil water content at field capacity, calculated using the SoilDataViewer and the Soil Survey Geographic database, in the Osage Nation watershed model area, Oklahoma and Kansas. 


\section{Surface Geology}

Surface geology for the ONWM was defined using the statewide geologic maps for Kansas and Oklahoma (Ross, 1991; Heran and others, 2003). Recent studies have refined the geology within the area of Osage Nation (Hudson and others, 2016), however, at the time of this study the extent of the refined geology was limited to the area of Osage Nation and did not cover the complete area of the ONWM. For reasons of maintaining consistency in the source data used as input for the ONWM, only the statewide geologic maps were used to define surface geology for all areas within the ONWM.

The surface geology in the ONWM area consists mostly of westward dipping sedimentary rocks, generally striking in a north-south alignment (fig. 16). In addition to the sedimentary rocks, most of the valley bottoms include unconsolidated and partially consolidated alluvial deposits overlying the sedimentary rocks. The sedimentary rock types include a variety of shales, limestones, and sandstones. Structural deformation of the dipping strata is minimal. In many areas, erosion and incision of stream channels across the dipping strata have resulted in irregular outcropping patterns by the dipping strata. Compared to the large areal extent of sedimentary rocks, the areal extent of alluvial deposits is generally limited to narrow, elongated features constrained to the lower elevations of the more prominent valleys.

The most prevalent rock formation in the ONWM area is the Oscar Group, consisting of shale and sandstone, covering about 17 percent of the ONWM area and outcropping in the west-central parts of the ONWM area and the western part of the ONIHM area (fig. 16; table 5). The Wellington and Vamoosa Formations, consisting of shale and sandstone, are also prominent, each covering about 11 percent of the ONWM area. The Wellington Formation is the major rock formation west of the ONIHM area and the Osage Nation, in the western part of the ONWM area, and the Vamoosa Formation is the major formation in the east-central part of the ONWM and the ONIHM areas. Alluvium also covers about 11 percent of the ONWM area and forms substantial deposits along the larger valley bottoms and tributaries in the Arkansas River drainage and the main branches of the Caney River and Bird Creek drainages. The Vanoss Group is the fifth most extensive surface geologic unit, covering about 10 percent of the area, and the Ada Group, consisting of shale and sandstone, is the sixth most prominent surface geologic unit in the ONWM area, covering about 8 percent of the area and outcropping in the northern, central, and southern parts of the ONWM and the ONIHM areas.

Three major aquifers underlie the Osage Nation and the general area of the ONWM: (1) alluvial and terrace aquifers, consisting of unconsolidated sands, silts, clays, and gravels deposited along streams and rivers during the Quaternary Period; (2) the Ada-Vamoosa aquifer, consisting of a sequence of sandstones, siltstones, shales, conglomerates, and limestones of the Vomoosa Formation and Ada Group deposited in marine environments during the Pennsylvanian

\section{EXPLANATION}

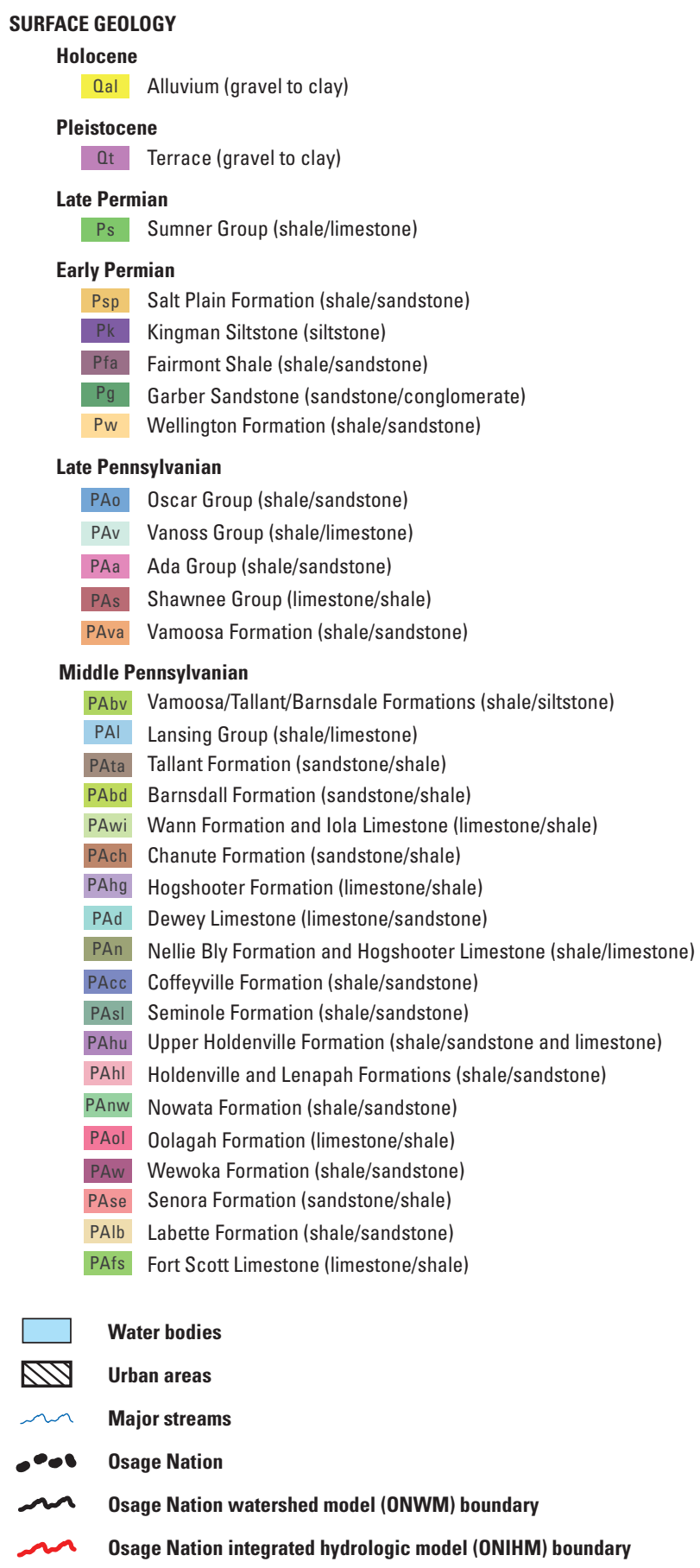

Figure 16. Surface geology, in the Osage Nation watershed model area, Oklahoma and Kansas (modified from Oklahoma and Kansas state geologic maps).

Period; and (3) minor bedrock aquifers deposited during the Pennsylvanian Period in the eastern part of the Osage Nation and during the Pennsylvanian through Permian Periods in the western part of the Osage Nation where the Ada-Vamoosa aquifer is absent (fig. 16; Andrews and Smith, 2014). 


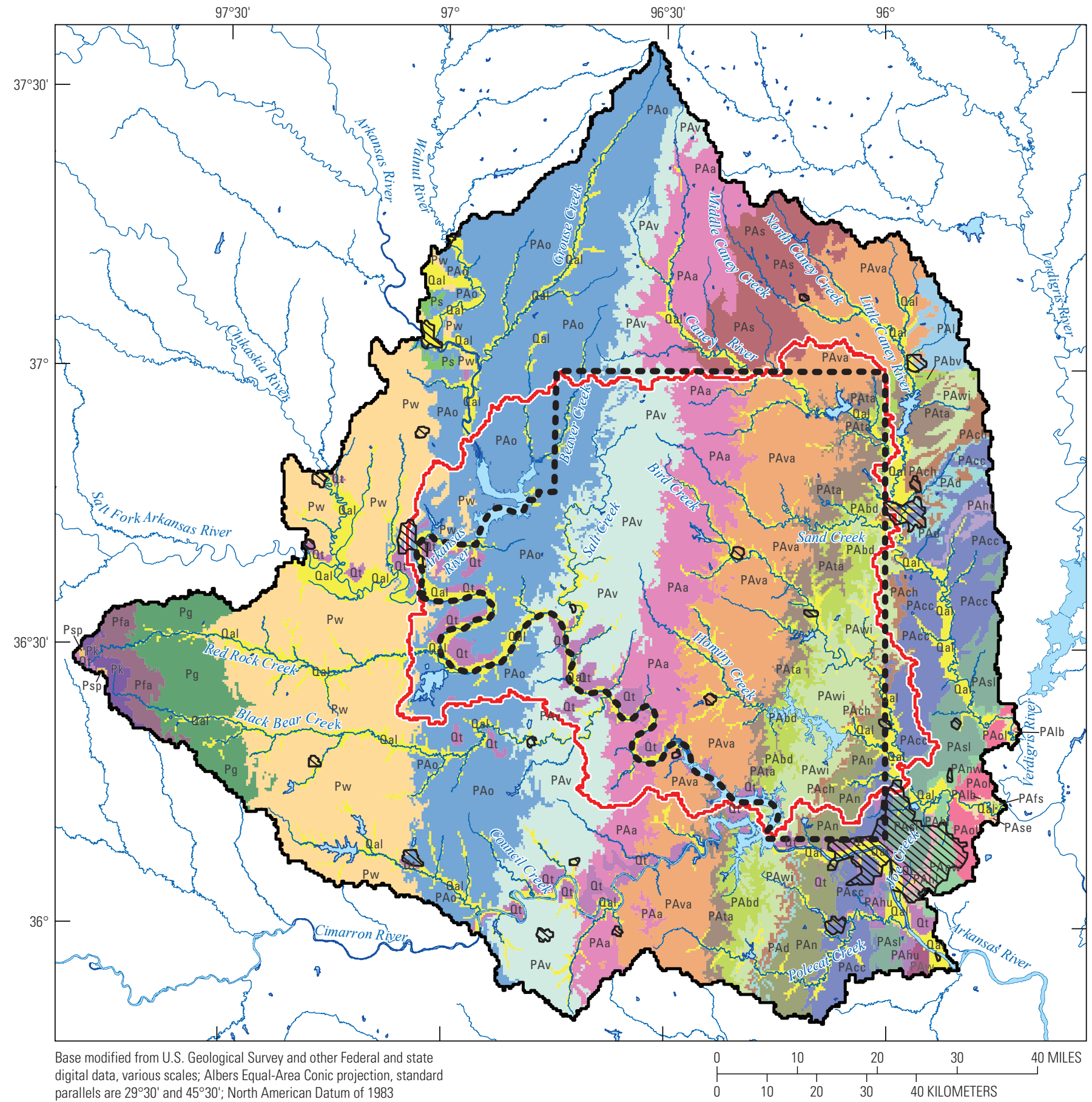

Figure 16. -Continued

Alluvial aquifers next to and underlying rivers and streams in the Osage Nation and surrounding region consist of unconsolidated lens-shaped beds of sand, silt, clay, and gravel (Andrews and Smith, 2014). Alluvium underlies river valleys and adjoins active stream channels, whereas terrace aquifers are at higher elevations and were deposited when the river bed was at a higher elevation (Andrews and Smith, 2014).
The alluvial and terrace aquifers generally have the greatest transmissivity compared with the Ada-Vamoosa aquifer and other bedrock aquifers in the ONWM area. The thickness of the alluvial and terrace aquifers, however, is small compared to the deeper consolidated-rock aquifers, and therefore, the storage capacity of the alluvial and terrace aquifers is also small compared to the deeper aquifers. 
Table 5. Surface geology of the Osage Nation watershed model (ONWM) area, Oklahoma and Kansas.

\begin{tabular}{|c|c|c|c|}
\hline $\begin{array}{l}\text { Surface geology } \\
\text { (rock types) }\end{array}$ & $\begin{array}{c}\text { Area } \\
\text { (square mile) }\end{array}$ & $\begin{array}{c}\text { Area } \\
\text { (acres) }\end{array}$ & $\begin{array}{l}\text { Percent of } \\
\text { ONWM area }\end{array}$ \\
\hline Oscar Group (shale/sandstone) & 1,444 & 924,300 & 17.31 \\
\hline Wellington Formation (shale/sandstone) & 958.3 & 613,300 & 11.49 \\
\hline Alluvium (gravel to clay) & 922.7 & 590,500 & 11.06 \\
\hline Vamoosa Formation (shale/sandstone) & 917.3 & 587,100 & 11.00 \\
\hline Vanoss Group (shale/limestone) & 805.6 & 515,600 & 9.66 \\
\hline Ada Group (shale/sandstone) & 666.1 & 426,300 & 7.98 \\
\hline Coffeyville Formation (shale/sandstone) & 355.3 & 227,400 & 4.26 \\
\hline Wann Formation and Iola Limestone (shale/sandstone) & 299.4 & 191,600 & 3.59 \\
\hline Tallant Formation (sandstone/shale) & 235.9 & 151,000 & 2.83 \\
\hline Shawnee Group (limestone/shale) & 232.0 & 148,500 & 2.78 \\
\hline Terrace (gravel to clay) & 216.5 & 138,600 & 2.60 \\
\hline Garber Sandstone (sandstone/conglomerate) & 205.5 & 131,500 & 2.46 \\
\hline Barnsdall Formation (sandstone/shale) & 177.4 & 113,600 & 2.13 \\
\hline Seminole Formation (shale/sandstone) & 167.9 & 107,500 & 2.01 \\
\hline Nellie Bly Formation and Hogshooter Limestone (shale/limestone) & 158.7 & 101,600 & 1.90 \\
\hline Water & 104.9 & 67,130 & 1.26 \\
\hline Chanute Formation (sandstone/shale) & 100.4 & 64,290 & 1.20 \\
\hline Fairmont Shale (shale/sandstone) & 60.2 & 38,550 & 0.72 \\
\hline Oolagah Formation (limestone/shale) & 52.6 & 33,690 & 0.63 \\
\hline Lansing Group (shale/limestone) & 51.0 & 32,620 & 0.61 \\
\hline Nowata Formation (shale/sandstone) & 45.6 & 29,180 & 0.55 \\
\hline Dewey Limestone (limestone/sandstone) & 45.3 & 29,020 & 0.54 \\
\hline Kingman Siltstone (siltstone) & 25.5 & 16,290 & 0.31 \\
\hline Vamoosa/Tallant/Barnsdall Formations (shale/siltstone) & 16.6 & 10,600 & 0.20 \\
\hline Holdenville Formation (shale/sandstone and limestone) & 16.2 & 10,400 & 0.19 \\
\hline Hogshooter Formation (limestone/shale) & 15.4 & 9,845 & 0.18 \\
\hline Holdenville \& Lenapah Formations (shale/sandstone) & 12.7 & 8,105 & 0.15 \\
\hline Sumner Group (shale/limestone) & 12.1 & 7,749 & 0.15 \\
\hline Labette Formation (shale/sandstone) & 8.3 & 5,337 & 0.10 \\
\hline Wewoka Formation (shale/sandstone) & 8.3 & 5,337 & 0.10 \\
\hline Salt Plain Formation (shale/sandstone) & 2.4 & 1,542 & 0.03 \\
\hline Wann Formation and Iola Limestone (limestone/shale) & 0.9 & 554 & 0.01 \\
\hline Fort Scott Limestone (limestone/shale) & 0.5 & 316 & 0.01 \\
\hline Senora Formation (sandstone/shale) & 0.5 & 316 & 0.01 \\
\hline
\end{tabular}




\section{Hydrology}

With the exception of the Arkansas River, hydrology in the ONWM study area consists of mostly natural, unrestricted surface water and groundwater conditions; however, a substantial part of the hydrologic system is affected by managed streamflows, reservoir operations, and surface-water diversions. In some areas, groundwater is also likely affected by well operations (pumping or injection). Natural drainage conditions generally exist for much of the upstream parts of drainages, and the smaller tributaries are mostly unimpeded flows. The larger water bodies in the ONWM area, however, are reservoirs, and the flows on the larger streams downstream from these reservoirs can be substantially affected by reservoir operations. These managed flows were not represented in the hydrologic system defined by the ONWM.

\section{Streamflow}

Streamflow in the ONWM study area is generally perennial in the larger stream channels; however, flows in the smaller tributaries can be ephemeral or intermittent (Andrews and Smith, 2014). In general, streamflow varies by several orders of magnitude for most stream channels. Streamflow response times to storms, which is the length of time between the onset of precipitation and increasing streamflow in the stream channel, is less than 24 hours at most of the firstorder streams and smaller tributaries. Response times along the longer flow paths connecting the drainage divides in the northern and western headwaters to the downstream sections of the larger streams and rivers, such as the lower sections of Caney River, Bird Creek, and the Arkansas River, is generally greater than 24 hours. In addition, response times can be much longer downstream from reservoirs that regulate peak flows during storms for flood control. Depending on reservoir operation, streamflow downstream from reservoirs is often not representative of streamflow generated in the upstream watershed, especially in response to daily conditions.

Continuous records of streamflow were available at 22 USGS streamgages in the ONWM area (table 2; fig. 2). Streamflow at the USGS streamgages was recorded at 15-minute intervals and was calculated as a discharge rate using continuous measurements of water height (stage) and stage-discharge curves (rating curves) fitted to measurements of stage, wetted area, and flow velocities recorded at each streamgage for a range of stage-discharge conditions. Continuous records of daily mean streamflow, calculated as the mean daily streamflow rate using the continuous record of 15-minute discharge from each streamgage, were available for the 22 streamgages from the USGS National Water Information System database (https://waterdata.usgs.gov/nwis, Sept. 15, 2015). In addition to the daily streamflow records, records of peak streamflows and field measurements of stage, wetted areas, flow velocities, and the developed rating curves were available for most of the streamgages. For the purposes of this study, the developed records of daily streamflow are referred to as "observations" to emphasize that these records are not direct measurements, but rather are estimates based on the measured stage values and the fitted rating curves.

Streamflow records for the ONWM area indicated a high degree of variability, with maximum observed flows approximately three to four orders of magnitude greater than minimum flows. The monthly distribution of streamflow was similar to the monthly distribution of precipitation; streamflow was highest during late spring (May and June) and lowest during winter (December and January). Along the Arkansas River, monthly streamflow deviated somewhat relative to monthly precipitation because of flow regulation at two major reservoirs, Kaw Lake and Keystone Lake. The characteristics of streamflow for the tributaries entering the ONWM area from the north and west were similar to the characteristics of streamflow for the major streams in the ONWM area. Andrews and Smith (2014) observed that the variability in streamflow in the ONWM area was strongly dependent on the variability of precipitation falling in the ONWM area; the maximum streamflow was a response to a major storm period during October 1986, and low-flow conditions were common in all major streams during dry periods.

The greatest streamflow in the ONWM study area was observed in the lower Arkansas River at streamgage ARKT (USGS 07164500, Arkansas River at Tulsa, OK; table 2). The ARKT streamgage is close to the outflow of the Arkansas River from the ONWM area, downstream from the Tulsa metropolitan area. Flow at the ARKT has been regulated by Keystone Lake since September 1964 (https://waterdata.usgs.gov/nwis/inventory/?site no $=07164500$, Sept. 15, 2015). The long-term mean annual streamflow at this streamgage during September 1964September 2014 was 8,420 cubic feet per second $\left(\mathrm{ft}^{3} / \mathrm{s}\right)$. The peak flow was $307,000 \mathrm{ft}^{3} / \mathrm{s}$ on October 5, 1986. The highest daily mean streamflow of $261,000 \mathrm{ft}^{3} / \mathrm{s}$ also was on this date. Of the flows at ARKT, 10 percent exceeded 22,200 ft $\mathrm{ft}^{3} / \mathrm{s}$, and 90 percent of the flows exceeded $505 \mathrm{ft}^{3} / \mathrm{s}$. The minimum daily mean streamflow was $28.7 \mathrm{ft}^{3} / \mathrm{s}$ on November 2, 2006. The highest mean monthly streamflow of $15,150 \mathrm{ft}^{3} / \mathrm{s}$ was in June, and the lowest mean monthly streamflow of $4,386 \mathrm{ft}^{3} / \mathrm{s}$ was in December (https://waterdata.usgs.gov/nwis/inventory/?site no $=07164500$, Sept. 15, 2015). 
The highest inflows to the ONWM area were in the Arkansas River at streamgage ARKA (USGS 07146500, Arkansas River at Arkansas City, KS) and in the Cimarron River at streamgage CIMP (USGS 07161000, Cimarron River at Perkins, OK; table 2). The long-term (water years 1903-2014) mean annual streamflow of the Arkansas River at streamgage ARKA was $1,939 \mathrm{ft}^{3} / \mathrm{s}$ (https://waterdata.usgs.gov/ nwis/inventory/?site_no $=07161000$, Sept. 15,2015$)$. The maximum daily mean streamflow was $79,700 \mathrm{ft}^{3} / \mathrm{s}$ on November 3, 1998, and the peak streamflow of $103,000 \mathrm{ft}^{3} / \mathrm{s}$ was on June 10, 1923. The lowest daily mean streamflow was $4 \mathrm{ft}^{3} / \mathrm{s}$ on October 23, 1921. The monthly distribution of streamflow at the ARKA streamgage was similar to the monthly distribution at the ARKT streamgage; the highest mean monthly flow was $3,749 \mathrm{ft}^{3} / \mathrm{s}$ in June, and the lowest mean monthly flow was $885 \mathrm{ft}^{3} / \mathrm{s}$ in January.

The mean annual streamflow in the Cimarron River at streamgage CIMR (USGS 07161450, Cimarron River near Ripley, OK) was $1,931 \mathrm{ft}^{3} / \mathrm{s}$ for water years 1988 2014 (https://waterdata.usgs.gov/nwis/inventory/?site_ no $=07164500$, Sept. 15, 2015). The highest daily mean streamflow of $137,000 \mathrm{ft}^{3} / \mathrm{s}$ was on May 10, 1993, and the peak flow of $141,000 \mathrm{ft}^{3} / \mathrm{s}$ was also on this date. The lowest daily mean streamflow of $15.7 \mathrm{ft}^{3} / \mathrm{s}$ was on September 2, 2011. The highest mean monthly streamflow of $3,931 \mathrm{ft}^{3} / \mathrm{s}$ at streamgage CIMR was in June, and the lowest mean monthly streamflow of $1,042 \mathrm{ft}^{3} / \mathrm{s}$ was in January. The mean annual streamflow in the Cimarron River at streamgage CIMG (USGS 07160000, Cimarron River near Guthrie, OK) was $1,130 \mathrm{ft}^{3} / \mathrm{s}$ for water years 1938-2014 (https://waterdata.usgs.gov/nwis/ inventory/?site_no $=07160000$, Sept. 15,2015$)$. The highest daily mean streamflow was $112,000 \mathrm{ft}^{3} / \mathrm{s}$, on May 17, 1957, at this streamgage, and the peak flow of $158,000 \mathrm{ft}^{3} / \mathrm{s}$ also was on this date. The lowest daily mean streamflow of $0.3 \mathrm{ft}^{3} / \mathrm{s}$ was on October 20, 1939. The highest mean monthly streamflow of $2,353 \mathrm{ft}^{3} / \mathrm{s}$ at streamgage CIMG was in May, and the lowest mean monthly streamflow of $492 \mathrm{ft}^{3} / \mathrm{s}$ was in January.

On the eastern side of the ONWM area, the mean annual streamflow for the Caney River for water years 1984-2014 at streamgage CANR (USGS 07175500, Caney River near Ramona, OK) was $1,560 \mathrm{ft}^{3} / \mathrm{s}$. The maximum daily mean streamflow was $71,700 \mathrm{ft}^{3} / \mathrm{s}$ at CANR, on October 5, 1986, and the minimum daily mean streamflow was $8.89 \mathrm{ft}^{3} / \mathrm{s}$, on November 4, 2006 (https://waterdata.usgs.gov/nwis/ inventory/?site no $=07175500$, Sept. 15, 2015). The highest mean monthly streamflows at CANR were in May, and the lowest mean monthly streamflows were in December. Streamflow in Bird Creek at streamgage BIRC (USGS 07178200, Bird Creek at State Highway 266 near Catoosa, OK) was less than the streamflow in the larger Caney River drainage; mean annual streamflow for water years 19892014 was $929.8 \mathrm{ft}^{3} / \mathrm{s}$ at streamgage BIRC. The maximum daily mean streamflow of 25,900 ft $3 / \mathrm{s}$ was on May 11, 1993, and the peak flow of $27,400 \mathrm{ft}^{3} / \mathrm{s}$ was also on this date. The minimum daily mean streamflow of $62 \mathrm{ft}^{3} / \mathrm{s}$ was on November 6, 1993. Similar to streamflows at CANR, the highest mean monthly flows at BIRC were in May, and the lowest mean monthly flows were in December.

\section{Water Bodies}

Water bodies in the ONWM area were defined as all areas covered by water the majority of time. Areas covered by water can fluctuate through time according to season and climate (wet compared with dry conditions), such that maximum areas are defined by flooding conditions and minimum areas are defined by drought conditions. Areas covered by water in reservoirs also fluctuate in response to reservoir operation. For this study, the areas of water bodies were defined as the maximum area covered by water under typical conditions, not that representative of either drought or flooding conditions.

The ONWM area includes 103 water bodies that have areas of 17 acres or greater, including lakes, ponds, wetlands, and reservoirs. The largest water bodies in the ONWM area are reservoirs, built from 1922 to 1984, mainly for flood control, water supply, hydropower, cooling water, and recreation (table 6). Twenty-two reservoirs in the ONWM area have normal pool areas of approximately 100 acres or more. Keystone Lake, Kaw Lake, and Skiatook Reservoir are the largest water bodies in terms of normal pool areas (fig. 1; table 6). Keystone Lake and Kaw Lake are major reservoirs on the Arkansas River and are used mostly for flood control, water supply, hydropower, and recreation. The operation of these reservoirs can strongly affect downstream flows, usually by decreasing peak flows and increasing low flows. Natural flows for the streams and rivers in the Osage Nation can be moderated downstream from Skiatook Reservoir on Hominy Creek, Copan Lake and Hulah Restocking Pond on the Little Caney and Caney Rivers, respectively, and Birch Reservoir on Bird Creek. The total area covered by these 22 reservoirs under normal pool conditions is about 76,100 acres, or about 1.4 percent of the ONWM area. Nine of the twenty largest reservoirs are in the Osage Nation (Osage County) and cover a total water area of about 33,800 acres, or about 2.3 percent of the area of the Osage Nation, under normal pool conditions. During flooding, however, the area covered by water can more than double for many of the reservoirs (table 6).

Although water bodies do not cover a large percentage of the total ONWM area, they can have an important effect on the overall hydrologic system by capturing and storing streamflow, generally causing a delay or dampening of peak streamflow. In addition, water bodies can cause an increase in the evaporation of surface water and, in many cases, an increase in seepage and recharge, depending on the depth to the underlying water table as well as the hydraulic conductivity of the soil and bedrock underlying the water body. 
Table 6. Major water bodies (greater than 100 acres) in the Osage Nation watershed model (ONWM) area, Oklahoma and Kansas.

[Reservoir uses: C, conservation; CW, cooling water; FC, flood control; FW, fish and wildlife; HP, hydroelectric power; LF, low-flow regulation; N, navigation; R, recreation; WQ, water quality; WS, water supply. Other abbreviations: - , data not available or not applicable]

\begin{tabular}{|c|c|c|c|c|c|c|c|c|c|c|c|c|}
\hline \multirow[b]{2}{*}{$\begin{array}{l}\text { Reservoir } \\
\text { name }\end{array}$} & \multirow[b]{2}{*}{$\begin{array}{c}\text { Surface- } \\
\text { water } \\
\text { drainage }\end{array}$} & \multirow[b]{2}{*}{ County } & \multirow{2}{*}{$\begin{array}{c}\text { Year } \\
\text { built or } \\
\text { com- } \\
\text { pleted }\end{array}$} & \multicolumn{4}{|c|}{ Normal conditions } & \multicolumn{3}{|c|}{ Flood conditions } & \multirow{2}{*}{$\begin{array}{l}\text { Water- } \\
\text { supply } \\
\text { yield } \\
\text { (acre-feet) }\end{array}$} & \multirow[b]{2}{*}{$\begin{array}{l}\text { Reservoir } \\
\text { uses }\end{array}$} \\
\hline & & & & $\begin{array}{c}\text { Area } \\
\text { (acres) }\end{array}$ & $\begin{array}{l}\text { Shore- } \\
\text { line } \\
\text { (miles) }\end{array}$ & $\begin{array}{c}\text { Elevation } \\
\text { (feet) }\end{array}$ & $\begin{array}{c}\text { Voume } \\
\text { (acre-feet) }\end{array}$ & $\begin{array}{c}\text { Area } \\
\text { (acres) }\end{array}$ & $\begin{array}{c}\text { Elevation } \\
\text { (feet) }\end{array}$ & $\begin{array}{c}\text { Volume } \\
\text { (acre-feet) }\end{array}$ & & \\
\hline Keystone Lake & Arkansas River & Tulsa & 1968 & 23,610 & 297 & 723 & 557,600 & 54,320 & 754 & $1,738,000$ & 22,400 & FC, WS, HP, N, FW \\
\hline Kaw Lake & Arkansas River & Osage & 1976 & 17,040 & 149 & 1,010 & 428,600 & 38,020 & 1,045 & $1,348,000$ & 187,000 & FC, WS, WQ, R, FW \\
\hline Skiatook Reservoir & Hominy Creek & Osage & 1984 & 10,190 & 187 & 714 & 322,700 & 13,690 & 729 & 500,700 & 15,680 & FC, WS, WQ, R, FW \\
\hline Sooner Lake & Greasy Creek & Pawnee & 1972 & 5,400 & 51 & 927 & 149,000 & - & - & - & 3,600 & $\mathrm{CW}$ \\
\hline Copan Lake & Little Caney River & Washington & 1983 & 4,850 & 50 & 710 & 43,400 & 13,380 & 732 & 227,700 & 3,360 & FC, WS, WQ, R, FW \\
\hline Hulah Restocking Pond & Caney River & Osage & 1951 & 3,570 & 70 & 733 & 31,160 & 13,000 & 765 & 289,000 & 13,890 & FC, WS, LF, C \\
\hline Lake Carl Blackwell & Stillwater Creek & Payne & 1937 & 3,370 & 59 & 944 & 61,500 & - & - & - & 7,000 & WS, R \\
\hline Lake McMurtry & North Stillwater Creek & Noble & 1971 & 1,155 & 24 & 950 & 19,730 & - & - & - & 3,002 & WS, FC, R \\
\hline Birch Reservoir & Birch Creek & Osage & 1977 & 1,137 & 31 & 750 & 19,200 & - & 774 & 58,200 & 3,360 & FC, WS, WQ, R, FW \\
\hline Lake Ponca & Turkey Creek & Kay & 1935 & 778 & 17 & 988 & 13,580 & - & - & - & 2,529 & WS, R \\
\hline Bluestem Lake & Middle Bird Creek & Osage & 1958 & 762 & 20 & 875 & 17,000 & - & - & - & - & WS, R \\
\hline Heyburn Reservoir & Polecat Creek & Creek & 1950 & 660 & 25 & 762 & 5,307 & 3,740 & 784 & 55,400 & 1,904 & $\mathrm{FC}, \mathrm{C}$ \\
\hline Cushing Lake & Big Creek & Payne & 1950 & 591 & 8 & 838 & 3,304 & - & - & - & - & WS, R \\
\hline Shell Lake & Shell Creek & Osage & 1922 & 573 & 11 & 725 & 9,500 & - & - & - & - & WS, R \\
\hline Lake Perry & Cow Creek & Noble & 1937 & 567 & 13 & 1,083 & 6,358 & - & - & - & - & WS, FC, R \\
\hline Lake Yahola & Flat Rock Creek & Tulsa & 1948 & 431 & 3 & 609 & 6,445 & - & - & - & - & WS, R \\
\hline Lake Sahoma & Rock Creek & Creek & 1947 & 312 & 8 & 716 & 4,850 & - & - & - & - & WS, R \\
\hline Pawnee Lake & Skedee Creek & Pawnee & 1932 & 310 & 5 & 867 & 3,533 & - & - & - & - & WS, R \\
\hline Boomer Lake & Boomer Creek & Payne & 1932 & 260 & 9 & 910 & 3,200 & - & - & - & - & $\mathrm{CW}, \mathrm{R}$ \\
\hline Hudson Lake & Butler Creek & Osage & 1949 & 250 & 10 & 756 & 4,000 & - & - & - & - & WS, R \\
\hline Hominy Municipal Lake & Claremore Creek & Osage & 1940 & 165 & 7 & 850 & 5,000 & - & - & - & - & WS, R \\
\hline Fairfax City Lake & Wild Creek & Osage & 1936 & 111 & 4 & 890 & 1,795 & - & - & - & - & WS, R \\
\hline Totals & - & - & - & 76,090 & - & - & $1,717,000$ & 136,200 & - & $4,217,000$ & 263,800 & - \\
\hline
\end{tabular}


The percentage of land area covered by water in the ONWM area, based on a 39.54-acre grid resolution, was calculated using the combined datasets for land cover (NLCD), soil (SSURGO), geology, and the National Hydrographic Dataset (NHD). The different datasets all included mapped areas for water bodies. To produce a consistent dataset representing the mapped water bodies, the different datasets were combined, and the result was expressed as the percentage of area covered by water per 39.54-acre grid cell (fig. 17). The combined dataset indicated that a total of about 171,700 acres, or 3.2 percent of the ONWM area, is covered by water under average conditions. The percentage of area covered by water for the ONWM area is about 1.2 percent more than the percentage indicated by the NLDC 2011 land-cover data, because a large number of the smaller water bodies identified by the higher resolution SSURGO and NHD datasets were not represented by the NLCD landcover data. The major reservoirs were indicated as areas covered by 50 to 100 -percent water per 39.54-acre grid cell (fig. 17). Many areas included small water bodies of 4 acres or less, covering 10 percent or less of a 39.54-acre cell. The total area covered by water in rivers and streams, wetlands, and the small lakes and ponds of less than 100 acres is about 95,560 acres, or about 26 percent greater than the area covered by the 22 reservoirs with normal pool areas of about 100 acres or greater (table 6). In the ONIHM area, about 88,000 acres, or 4.9 percent of the total area, is covered by water bodies under normal conditions, including the large reservoir areas and the rivers, streams, wetlands, and small lakes and ponds.

\section{Groundwater}

Fresh groundwater in the Osage Nation is most abundant in alluvial aquifers along streams and in the Ada-Vamoosa aquifer (Bingham and Bergman, 1980). Yields of groundwater from minor bedrock aquifers, which include thin layers of sandstone and limestones, are relatively small (Bingham and Bergman, 1980). Alluvial aquifers in the Osage Nation are likely to produce relatively large well yields compared to adjoining and underlying bedrock aquifers (Bingham and Bergman, 1980). The Ada-Vamoosa aquifer, which underlies a large part of the Osage Nation, generally produces smaller well yields than alluvial aquifers. D'Lugosz and others (1986) described selected properties of the Ada-Vamoosa aquifer in the Osage Nation and counties to the south that can be used for planning purposes. Parts of the Ada-Vamoosa aquifer that have larger sandstone thicknesses are likely to have greater hydraulic conductivities, transmissivities, and well yields than other parts of the aquifer. Such areas are likely to be the most productive for a large number of wells for domestic or other local uses. Estimated thicknesses of alluvial aquifers in the Osage Nation are relatively small, generally less than $100 \mathrm{ft}$, whereas the thickness of freshwater in the AdaVamoosa aquifer can be several hundred feet (Andrews and Smith, 2014).

\section{Land and Water Use}

With the exception of the Tulsa metropolitan area in the southeastern part of the ONWM area, the ONWM area, including the Osage Nation, is generally sparsely populated, with a population density of about 21 residents per square mile (Andrews and Smith, 2014). The primary economic activities in this area are cattle ranching and extraction of petroleum and natural gas (Andrews and Smith, 2014). In the ONWM area, agricultural activities are more common outside of the Osage Nation, particularly in the western parts of the ONWM area (fig. 11).

The primary water sources used in the ONWM area are surface water withdrawn from Keystone Lake, Kaw Lake, and Skiatook Reservoir (table 6). The primary water sources used in the Osage Nation are Skiatook Reservoir and groundwater withdrawn from alluvial aquifers and the Ada-Vamoosa aquifer (Andrews and Smith, 2014). Within the Osage Nation, predominant fresh surface-water uses and fresh groundwater uses in 2010 were for public water supply, livestock, and industrial purposes. The city of Hominy and Hominy Indian Village use Hominy Lake as the sole source for public water supply. From 1890 through 2010, estimated freshwater use in the Osage Nation gradually increased from less than 1 million gallons per day $(\mathrm{Mgal} / \mathrm{d}$, or 1,121 acre-ft/yr) to nearly $19 \mathrm{Mgal} / \mathrm{d}$ (21,000 acre-ft/yr), and surface-water withdrawals from Skiatook Reservoir were the dominant water source (Andrews and Smith, 2014). Total estimated fresh surfacewater withdrawals and groundwater withdrawals increased from 0.75 to $16.19 \mathrm{Mgal} / \mathrm{d}(841-18,150 \mathrm{acre}-\mathrm{ft} / \mathrm{yr})$ and from 0.13 to $2.39 \mathrm{Mgal} / \mathrm{d}$ (146-2,680 acre-ft/yr), respectively, from 1890 to 2010 in the Osage Nation (Andrews and Smith, 2014). Much of the increase in freshwater use can be attributed to an increase in human population in the area, increased per capita water use by humans, and developments in infrastructure and technology that increased water withdrawals for industry and irrigation (Andrews and Smith, 2014). Increased human population and development of the Tulsa metropolitan area, including cities such as Sapulpa and Sand Springs, are likely to increase demand for freshwater in the Osage Nation both from lakes and groundwater (Andrews and Smith, 2014).

According to Andrews and Smith (2014), water resources are sufficient for current land uses and economic activities in most of the Osage Nation. Annual estimated combined surface-water and groundwater consumptive withdrawals of 18.6 Mgal/d (21,000 acre-ft/yr), based on water year 2010 annual total withdrawals, indicated that only about 1 percent of freshwater resources were for consumptive uses under typical (water year 2010) conditions (Andrews and Smith, 2014). Non-consumptive water uses in the ONWM area include recreation, power generation, and cooling water for power generation, navigation, and habitat for fish and wildlife (table 6). 


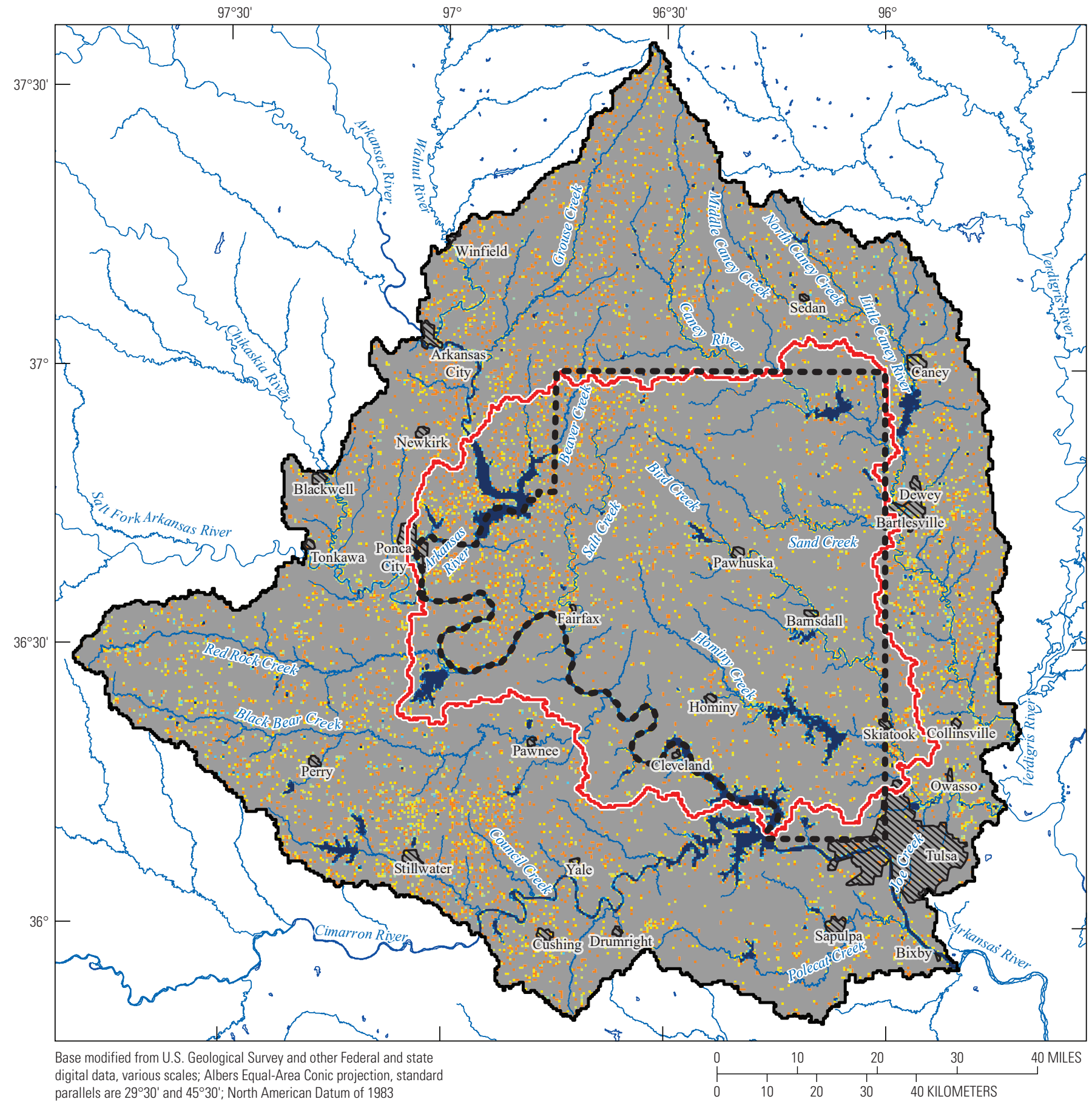

parallels are $29^{\circ} 30^{\prime}$ and $45^{\circ} 30^{\prime}$; North American Datum of 1983

EXPLANATION
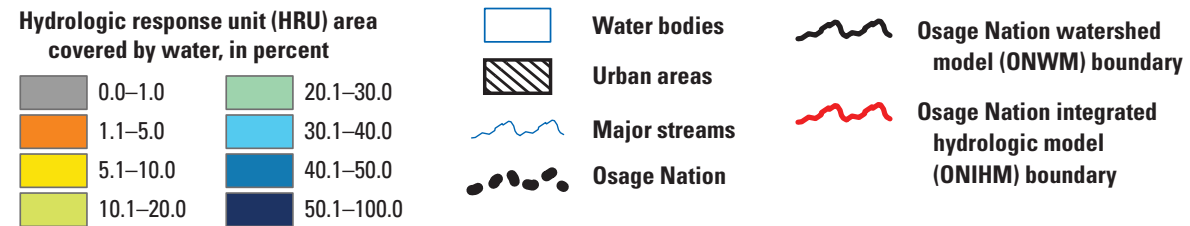

Figure 17. Calculated percentage of land covered by water, Osage Nation Watershed Model area, Oklahoma and Kansas. 


\section{Model Development}

Development of the ONWM consisted of (1) defining a conceptual model and selecting an appropriate model code, (2) defining the simulation period and initial conditions, (3) defining the model layout and spatial discretization, (4) development of initial input parameters representing the physical characteristics of the model domain, (5) development of climate inputs consisting of daily precipitation and maximum and minimum daily air temperature, (6) defining the inflow boundary conditions, and (7) model calibration.

\section{Conceptual Model}

The conceptual model used for the ONWM was primarily defined by PRMS, a widely used and well documented modeling program developed and supported by the USGS (Markstrom and others, 2015). The most recent version of the PRMS software available at the time of this study, version IV (PRMS-IV), was used to develop the ONWM. First developed in 1983 (Leavesley and others, 1983), PRMS has been applied extensively to hydrologic studies over a broad range of areas and for a variety of objectives (Markstrom and others, 2015; Woolfenden and Nishikawa, 2014; LaFontaine and others, 2013; Jeton and Maurer, 2011; Koczot and others, 2005; Jeton, 1999). Documentation about the use and the theory that led to the development of PRMS is widely available (Markstrom and others, 2015; Hunt and Garcia, 2014).

PRMS was developed by the USGS as a tool for assessing hydrologic responses to normal and extreme climatic conditions or to changes in climate or the physical conditions of a watershed (Leavesley and others, 1983; Markstrom and others, 2015). Applications of PRMS can be used to simulate basin response to normal and extreme precipitation (or lack of precipitation) and to spatial and temporal variability and trends in climate; to evaluate water budgets; and to evaluate changes in the hydrologic system, such as flow regimes, flood peaks and volumes, soil-water relationships, and groundwater recharge. Through parameter optimization and sensitivity analysis, models developed using PRMS can be calibrated to multiple streamgages to reflect a variety of physiographic characteristics (Hunt and Garcia, 2014).

As represented by PRMS, the conceptual model of the ONWM was based on known and estimated physical and hydrologic characteristics of the land and shallow subsurface and how these characteristics influence the flow and storage of water in the landscape. The dominant components of the ONWM are the surface and shallow-subsurface hydrologic systems (primarily the root zone). The conceptual model for the ONWM used a simplified representation of the deeper subsurface below the root zone that includes the groundwaterflow system. The simplified representation accounted for the component of total streamflow that originates as groundwater discharge to stream channels (also referred to as the base-flow component of streamflow), which was important for model calibration and the simulation of water budgets. In addition to the simplified representation of the groundwater-flow system, the ONWM used a simplified representation of streamflow in the major river channels and larger water bodies. To simulate streamflow lag times and the natural attenuation of flood waves moving through the stream network, the ONWM used the Muskingum streamflow-routing module available with PRMS-IV (Markstrom and others, 2015). The Muskingum routing option allowed for the representation of streamflow lag times longer than one day, which are characteristic of the main river systems in the ONWM area, such as the Arkansas River and the lower sections of Caney River and Bird Creek.

The surface and shallow-subsurface hydrologic systems simulated by the ONWM included the plant canopy, snowpack, land surface, soil zone, and groundwater reservoir supplying groundwater discharge to the stream channels. Boundary conditions included in the ONWM were daily climate inputs (precipitation and maximum and minimum air temperature) and daily streamflows. The plant canopy included natural vegetation, crops, and landscaped urbanized areas. The two types of land surfaces were pervious and impervious areas, with impervious areas representing develop land surfaces, such as rooftops, roads, and parking lots. The soil zone was defined as underlying the pervious land areas and was conceptually represented in the ONWM as extending from the ground surface to the base of the root zone (Markstrom and others, 2008; Markstrom and others, 2015). The soil zone was used to simulate the storage and transfer of water to the atmosphere as ET, through the soil to stream channels as interflow, and to the groundwater reservoirs as recharge. Areas with thin soil cover underlain by relatively impervious bedrock were represented using smaller storage capacities for the soil zone and a very low value for the PRMS parameter controlling the recharge rate through the soil zone.

Using PRMS, the ONWM was designed with the concept of partitioning the hydrologic system into a connected network of water-storage reservoirs and deterministic processes controlling water flow into and out of the various storage reservoirs (fig. 18A). The water-storage reservoirs consist of (1) interception storage by the plant canopy, (2) the snowpack, (3) retention storage on impervious surfaces, (4) depression storage used to represent water bodies on pervious areas (fig. 18B), (5) the soil-zone storage underlying pervious areas, and (6) the groundwater reservoir. The soil zone was divided into the preferential-flow reservoir, the capillary reservoir, and the gravity reservoir (fig. 18B). Deterministic processes affecting inflows and outflows were controlled by climate, parameters used to represent the properties of the various reservoirs, and the simulated water contents of the various different reservoirs. The primary sources of water to the ONWM were precipitation and surface water inflows to the Arkansas River subdrainage from the Walnut, Arkansas, Chikaskia, Salt Fork Arkansas, and Cimarron Rivers (fig. 2). 
Precipitation was simulated as either rain or snow, depending on the month and the maximum and minimum daily air temperature. Irrigation and flow diversions in the ONWM were assumed to be minor compared to precipitation and river inflows, especially in the ONIHM area, where the percentage of irrigated agricultural land is small. On the western side of the ONWM, irrigated croplands are more prevalent (fig. 11); however, it was assumed for the ONWM conceptual model that irrigation water is returned to the atmosphere by ET.

As defined by the PRMS conceptual model, the basic homogeneous water-storage reservoir used to spatially partition and discretize the ONWM domain is the hydrologic response unit (HRU). Water flow paths in the ONWM were defined by connecting HRUs to groundwater reservoirs, other HRUs, and stream segments. Using a combination of cascading flow connections between HRUs and groundwater reservoirs and of streamflow connections between HRUs, groundwater reservoirs, and stream segments representing the stream network, water was routed through the ONWM domain as Hortonian and Dunnian surface runoff, fast and slow interflow, groundwater flow, and base flow. Recharge from HRUs was routed to the groundwater reservoir linked to each HRU. Groundwater was routed from upslope to downslope groundwater reservoirs using a network of cascading flow connections matched to the cascading flow connections used for HRUs. Precipitation (as either rain or snow) was the inflow to the HRU network. Outflows from the HRU network were ET, surface runoff and interflow to stream segments, and recharge to groundwater reservoirs. Outflows from the groundwater reservoirs were groundwater losses and base flow (groundwater discharged to stream segments). In the ONWM conceptual model, groundwater losses were collectively represented as a groundwater-sink component (fig. 18A) and included groundwater pumped from wells, groundwater lost to ET, increases in groundwater storage in groundwater reservoirs not contributing to base flow, and groundwater underflow across surface-water divides.

The ONWM uses the cascading flow module in PRMS to simulate flow process for HRUs and groundwater reservoirs upstream from the stream segments defining the larger streams in the drainage network. All HRUs and groundwater reservoirs upstream from the stream channel network are linked into the cascading flow drainage network. Cascading flow for HRUs includes Hortonian and Dunnian surface runoff from pervious areas, Hortonian runoff from impervious areas, and slow and fast interflow from the soil zone. Cascading runoff and interflow can contribute to ET in the process of routing from upstream to downstream HRUs. Cascading groundwater flow can contribute to groundwater losses in the process of routing from upstream to downstream groundwater reservoirs.

Water bodies were represented in the ONWM using the depression-storage module available in PRMS-IV. The depression-storage module allowed the partitioning of HRUs into subareas representing permanent or temporary water bodies linked to the HRU and groundwater cascading flow paths. The depressions caused a portion of the water being routed to accumulate in the HRU area according to specified maximum depression areas and depths. Changes in the volume of water stored in each depression were simulated as a function of the inflows and outflows. Inflows to depressions were precipitation, surface runoff and interflow from the HRU containing the depression, and groundwater inflow from the groundwater reservoir underlying the depression. Outflows from depressions were surface runoff to the downstream HRU or stream segment, evaporation, and seepage recharge to the groundwater reservoir underlying the depression.

Simulations using the ONWM were run as a continuous daily water balance computed for each HRU, groundwater reservoir, and stream segment. Water storage, inflows, and outflows were simulated as a water-equivalent depth for the area of each HRU and groundwater reservoir. The sum of the responses of all HRUs and groundwater reservoirs, weighted on a unit-area basis, produced the daily hydrologic response and streamflow from the watershed. Partitioning the model domain into HRUs and groundwater reservoirs provided the ability to impose spatially distributed land-use or climate changes in the model domain and to evaluate resulting hydrologic effects in each HRU, as well as the entire ONWM area, or to selected subareas of the ONWM.

As applied in the ONWM, PRMS is used primarily to simulate surface and shallow-subsurface hydrologic processes under natural conditions in response to precipitation. In addition to precipitation, inflows to the ONWM include streamflow from the Walnut, Arkansas, Chikaskia, Salt Fork Arkansas, and Cimarron Rivers. In this study, streamflow simulated under natural conditions represents streamflow generated within the ONWM area in response to precipitation only and derived from hydrologic processes that are not affected by anthropogenic influences, specifically diversions, discharges, dams, and other conditions affecting the natural streamflows. 
A
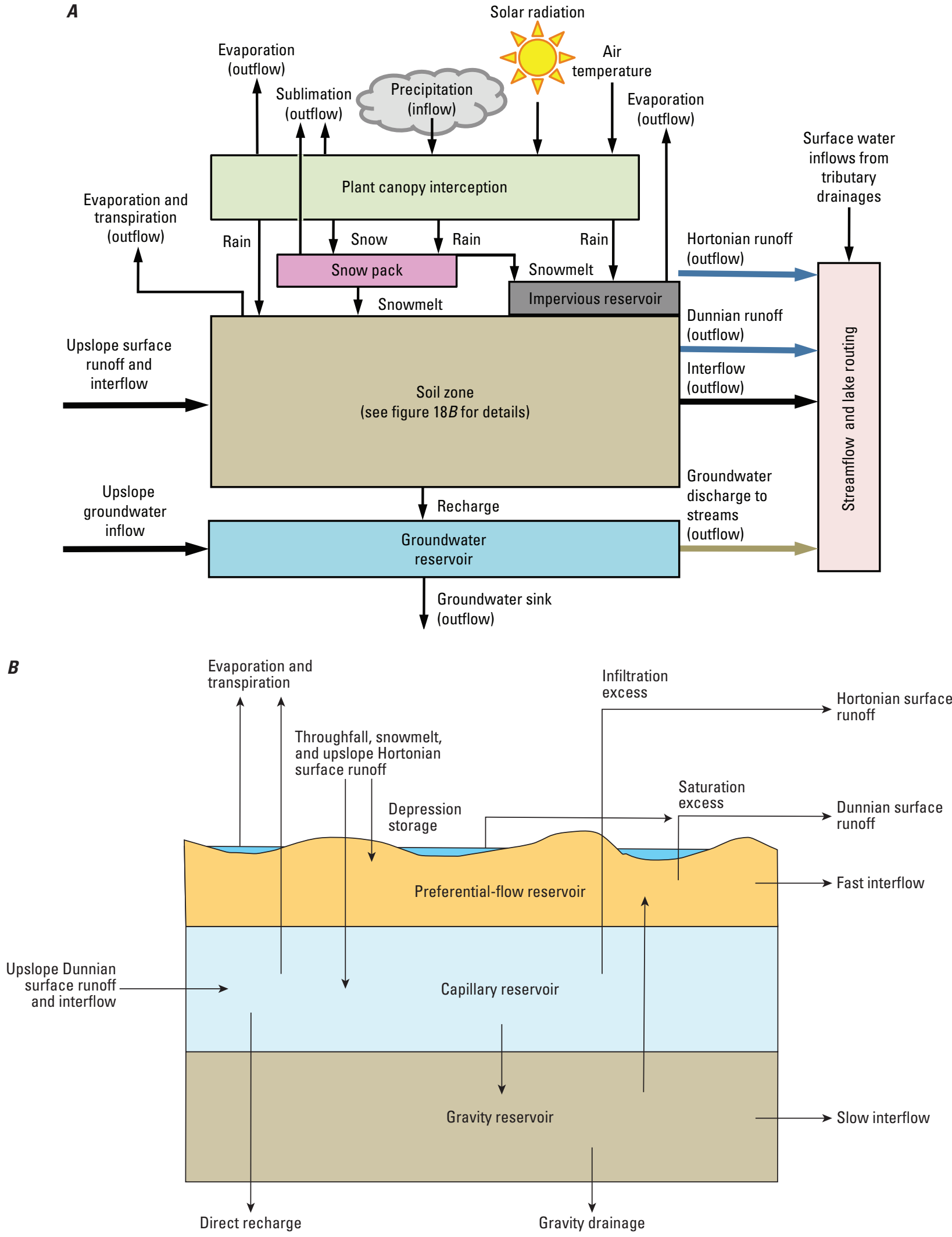

Figure 18. Conceptual model used for the Osage Nation Watershed Model, Oklahoma and Kansas: $A$, model components of the Precipitation-Runoff Modeling System (modified from fig. 1 in Markstrom and others, 2015), and B, soil-zone model components of the Precipitation-Runoff Modeling System (modified from fig. 2 in Markstrom and others, 2015). 


\section{Simulation Period}

The target simulation period defined for the ONWM was a continuous 100-year period starting with water year 1915 (October 1, 1914) and ending with water year 2014 (September 30, 2014). The target simulation period was used to estimate the long-term water budget and to analyze the spatial and temporal variability of the water-budget components, including ET, surface and subsurface water storage, recharge, and streamflow. Simulations were run starting on October 1, 1909, to allow for a 5-year model initialization period prior to the target period. Precipitationrunoff models, including PRMS, generally require an initialization period to help minimize uncertainties associated with the assumed or estimated initial conditions. The longer the initialization period, the less effect the initial conditions have on simulation results for the target simulation period. Initial conditions for the ONWM consisted of specified water contents for all storage components, including the snowpack, vegetation canopy, depressions, impervious areas, the three components of the soil zone, and the groundwater reservoir. In most cases, a 1-year initialization period is considered adequate for locations where snow cover does not persist through the summer months (Markstrom and others, 2008). For the ONWM, a longer 5-year initialization period was used to reduce uncertainty associated with the estimated initial water contents for the groundwater reservoirs.

\section{Model Layout and Discretization}

Spatial discretization consisted of defining the geometry and layout of the HRUs, groundwater reservoirs, and stream segments used to represent the physical characteristics of the ONWM domain, including spatial heterogeneity in topography, vegetation and land cover, soils, geology, water bodies, and climate. The ONWM was developed using a grid-based discretization to define homogeneous HRUs, with the grid-cell spacing, orientation, and extent defining the HRU layout. The grid-based discretization resulted in a large number of HRUs, groundwater reservoirs, and stream segments, allowing the heterogeneity of the ONWM domain to be more directly defined by the available GIS datasets used to develop model parameters. For the ONWM layout, each HRU was linked to its underlying groundwater reservoir. The gridded discretization for the HRUs and groundwater reservoirs followed the approach used in previous PRMS applications (Jeton and Maurer, 2011), as well as other precipitation-runoff modeling applications such as Topmodel (Beven and Kirkby, 1979), the Basin Characterization Model (Flint and Flint, 2007), the INFIL model (Hevesi and Christensen, 2015), and the Groundwater and Surfacewater Flow model (GSFLOW; Markstrom and others, 2008; Woolfenden and Nishikawa, 2014). In addition to defining the stream segments, the gridded discretization allowed for a spatially distributed representation of heterogeneities in climate and the physical characteristics of the watersheds included in the ONWM.

The ONWM discretization was defined using an equidimensional grid-cell dimension of 1,312.3 ft by $1,312.3 \mathrm{ft}$ (400 meters; m; by $400 \mathrm{~m}$ ), resulting in square HRUs and underlying groundwater reservoirs with equal areas of approximately 39.54 acres, and a total of 135,044 HRUs and connected groundwater reservoirs (fig. 19; table 1). The grid was aligned and georeferenced according to the Albers equal-area conic projection, North American Datum of 1983. The selection of grid-cell size and orientation was determined by several factors, including the $98-\mathrm{ft}(30-\mathrm{m})$ grid resolution of the digital elevation model (DEM) data used to define elevation and topography, the resolution of the NHD hydrography data (including stream lines, water bodies, and drainage boundaries), and the desired grid-cell resolution of the MODFLOW-OWHM component of the ONIHM.

The grid-cell connections defining the upstream and downstream HRUs for surface-runoff, interflow, and the upstream and downstream groundwater reservoirs for groundwater flow, were developed using a combination of grid-cell elevations and mapped hydrographic features. The HRU and groundwater reservoir connections are used in PRMS for simulating cascading flow between HRUs and between groundwater reservoirs and for simulating inflows to stream segments from upstream HRUs and groundwater reservoirs. For the ONWM setup, the discretization of the groundwater reservoirs was matched to the HRU discretization, and the cascading flow connections for groundwater reservoirs were also matched to the cascading flow connections for HRUs. The simulated inflows to stream segments included surface-runoff (Hortonian and Dunnian flow) and interflow (fast and slow interflow) routed through the cascade connections for HRUs and groundwater discharge routed as groundwater flow through the cascade connections for groundwater reservoirs.

The mean HRU elevations were defined using the 98- $\mathrm{ft}$ DEM (Gesch and others, 2009) compiled from the National Elevation Dataset (NED; U.S. Geological Survey, 2016). Initial flow directions defining the HRU and groundwater reservoir cascade connections were developed using the standard eight-direction routing (D-8) method (Maidment, 2002). The D-8 "many-to-one" routing method specifies a single downstream HRU for each upstream HRU, and a given HRU can receive inflows from one to eight adjacent and upstream HRUs. With D-8 flow routing, flow was allowed in the diagonal direction across the shared corner of adjacent HRUs, and in many areas of the ONWM, this provided a better match to the mapped streamlines and drainage divides compared to only allowing flow in the four orthogonal directions of adjacent HRUs with shared sides. For some parts of the ONWM, the flow directions that were initially defined using D-8 routing and HRU elevations, in which flow was routed from higher to lower elevation HRUs, were subsequently modified to provide a better match to the NHD hydrography. 


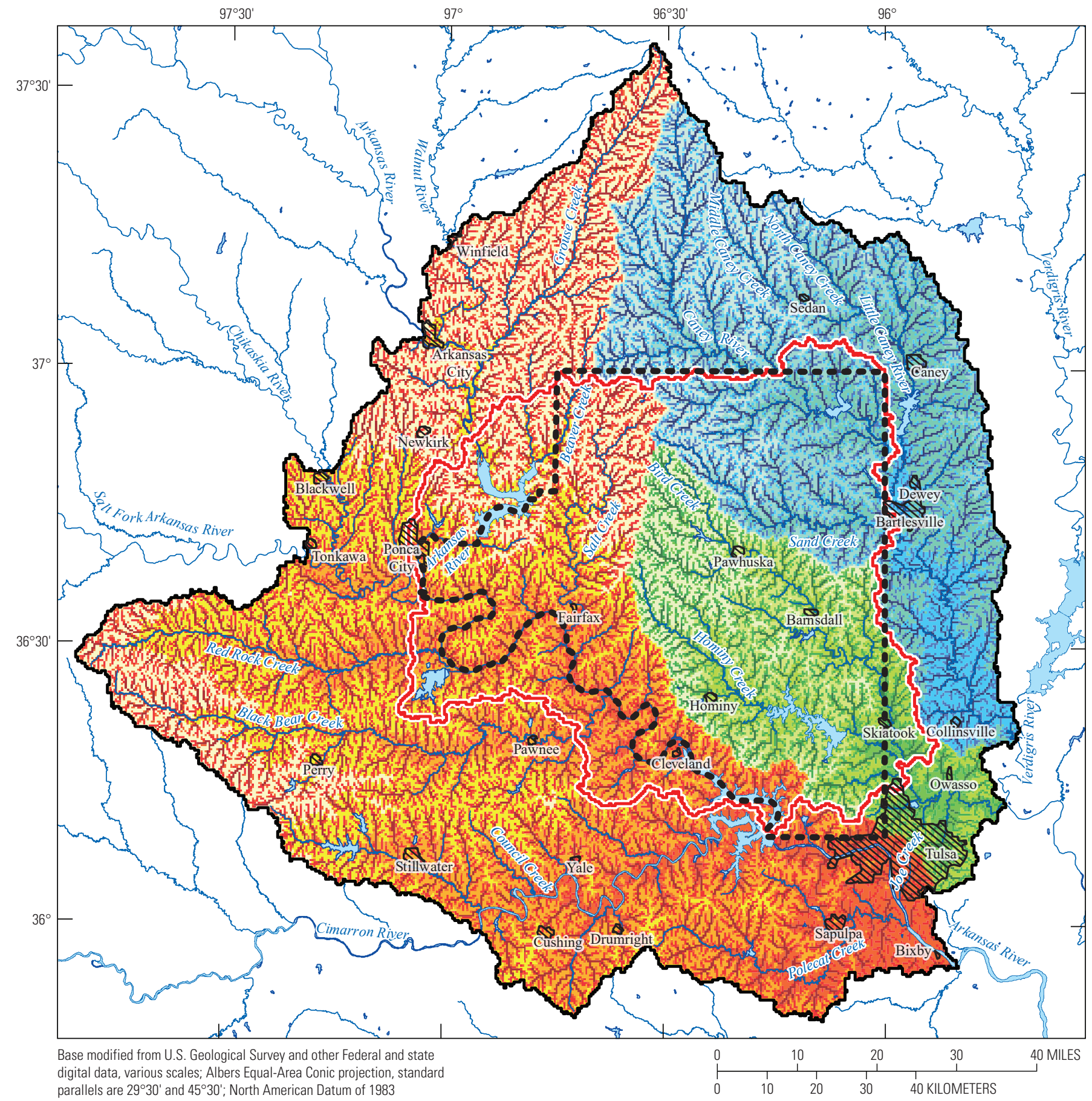

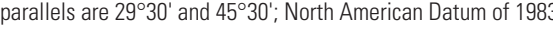

EXPLANATION

\begin{tabular}{|c|c|c|c|}
\hline \multicolumn{3}{|c|}{ Hydrologic response unit (HRU) number, by surface water drainage and and subdrainage } & Water bodies \\
\hline Arkansas River & Caney River & Bird Creek & \\
\hline $1-13,790$ & $82,742-88,390$ & $116,640-119,706$ & Uroan areas \\
\hline $13,791-27,580$ & $88,391-94,040$ & $119,707-122,774$ & Major streams \\
\hline $27,581-41,370$ & $94,041-99,690$ & $122,775-125,841$ & Osage Nation \\
\hline $41,371-55,160$ & $99,691-105,339$ & $125,842-128,909$ & \\
\hline $55,161-68,950$ & $105,340-110,989$ & $128,910-131,976$ & model (ONWM) boundary \\
\hline $68,951-82,741$ & $110,990-116,639$ & $131,977-135,044$ & $\begin{array}{l}\text { Osage Nation integrated } \\
\text { hydrologic model } \\
\text { (ONIHM) boundary }\end{array}$ \\
\hline
\end{tabular}

Figure 19. Model layout showing hydrologic response units used in the Osage Nation Watershed Model, Oklahoma and Kansas. 
The cascade-routing network was configured according to the three major surface-water drainages within the ONWM: (1) the Arkansas River subdrainage, (2) the Caney River drainage, and (3) the Bird Creek drainage. In each of the major surface-water drainages, the HRUs were numbered according to the order defined by the cascade routing sequence; the upstream HRUs were assigned the lowest number, and the downstream HRUs were assigned the highest number (fig. 19). The Arkansas River subdrainage included HRUs 1 through 82,741; the Caney River drainage included HRUs 82,742 through 116,639; and the Bird Creek drainage included HRUs 116,640 through 135,044 . The cascading routing network was linked to a network of 7,389 stream segments defining the larger streams and rivers in the ONWM (fig. 20). The stream-segment layout was defined such that each HRU and underlying groundwater reservoir along the stream network contained a single stream segment collecting the surface runoff, interflow, and groundwater discharge from the connected HRU and underlying groundwater reservoir as well as the streamflows from upstream segments. Similar to the ordering used to define HRU numbers, the stream-segment numbers were defined by the three subdrainages and by the flow-routing sequence in each subdrainage. The Arkansas River subdrainage included stream segments 1 through 4,672; the Caney River drainage included stream segments 4,673 through 6,357; and the Bird Creek drainage included stream segments 6,358 through 7,389 . 


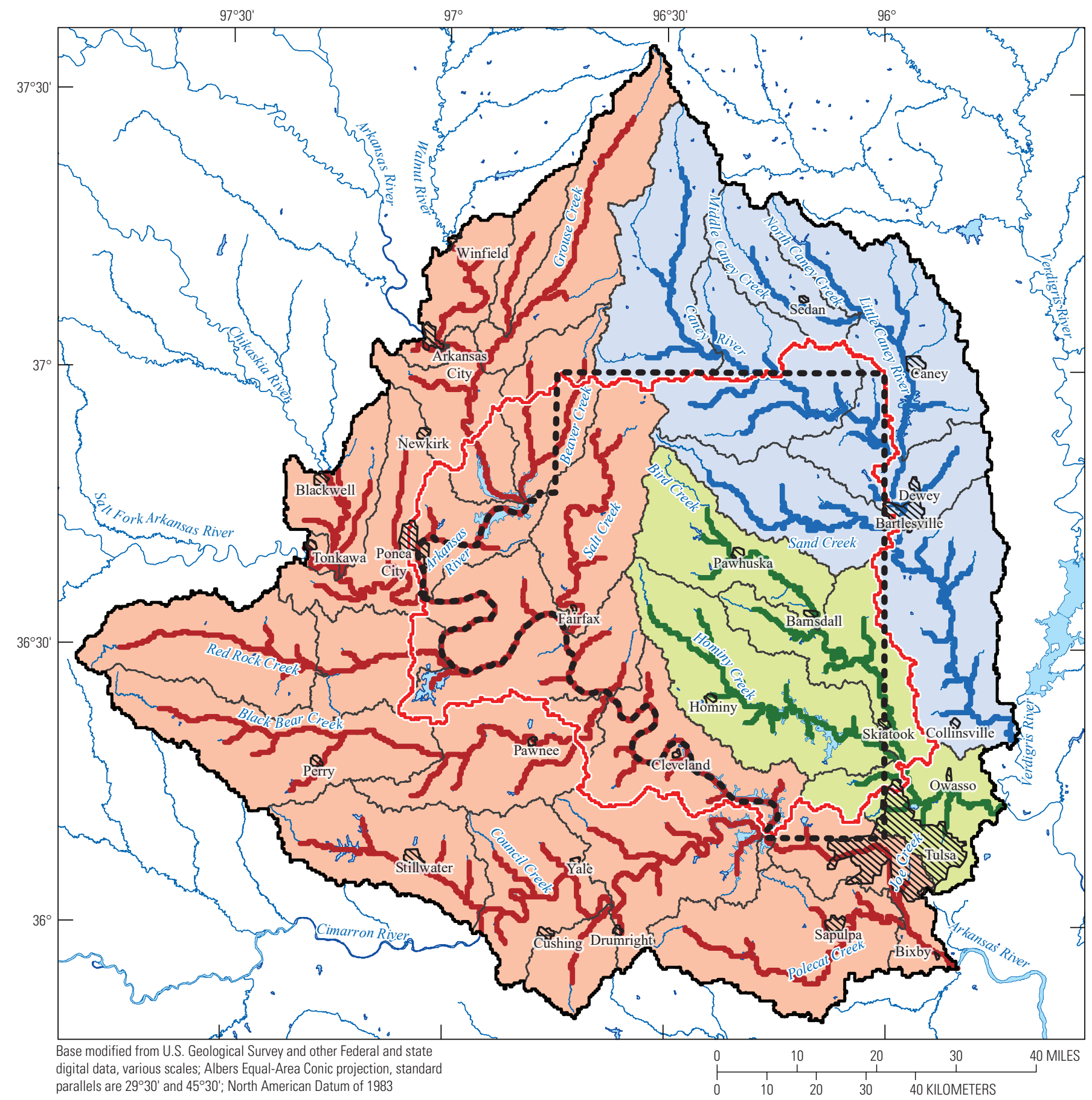

EXPLANATION

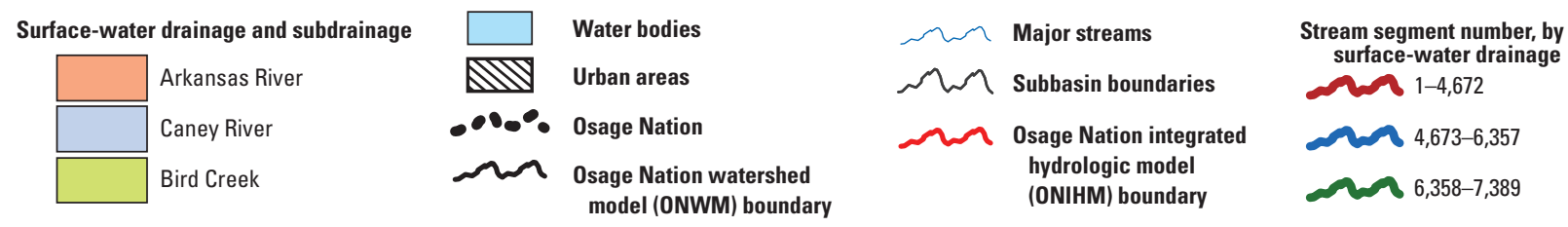

Figure 20. Model layout showing major stream channels defined as stream segments in the Osage Nation Watershed Model, Oklahoma and Kansas. 


\section{Model Parameters}

Model parameters defining the physical characteristics of watersheds, including land surface, land cover, shallow subsurface including the soil and root zone, and the nearsurface geology underlying the shallow subsurface, can be grouped into parameters representing (1) topography, (2) land cover, (3) soils, (4) geology, (5) water bodies, and (6) major streams. Initially, model parameters were defined by GIS datasets and preprocessing routines or by representative values based on previous studies, including default values provided in the PRMS user's manual (Markstrom and others, 2015). Many parameters were defined directly using GIS, such as the HRU elevation ( $h r u \_$elev), slope ( $\left.h r u \_s l o p e\right)$, and aspect (hru_aspect; table 7). These parameters have a high degree of certainty and were held constant during the model-calibration procedure. In many cases, initial estimates for critical parameters having a medium to high degree of uncertainty, such as carea_max, smidx_coef, smidx_exp, fastcoef_lin, and fastcoef_sq, were estimated using GIS and spreadsheet applications and were then adjusted and refined during the model-calibration procedure (table 7).

\section{Topography}

The 98-ft (30-m) resolution DEM (Gesch and others, 2009) was used to define the topographic parameters consisting of the HRU average elevation, slope, and aspect. Elevation ( $\left.h r u \_e l e v\right)$, slope ( $\left.h r u \_s l o p e\right)$, and aspect ( hru_aspect) are used in PRMS to simulate short-wave radiation (SWRAD) and potential evapotranspiration (PET). For the ONWM, slope is also used to estimate the PRMS parameters controlling the rate of Hortonian runoff as well as parameters controlling the fast and slow interflow components of subsurface flow through the soil zone. PRMS parameters controlling the rate of Hortonian runoff simulated by the ONWM are carea_max, smidx_coef, and smidx_exp (Markstrom and others, 2015; table 7). In the ONWM, the HRUs with higher slope have higher values for carea_max and smidx_coef, increasing the magnitude of Hortonian runoff generated for these HRUs. PRMS parameters used in the ONWM to control the rate of fast interflow are fastcoef_lin and fastcoef_sq, and parameters used to control the rate of slow interflow are slowcoef_lin and slowcoef_sq (table 7). Fast interflow represents flow through macropores in the soil zone along preferential-flow paths that are separate from the soil matrix. The volume of fast interflow that is preferential flow is controlled by the parameter pref_flow_den, which defines the relative fraction of maximum soil-zone water storage greater than capillary reservoir storage that is available for preferential flow (Markstrom and others, 2015; table 7). Slow interflow simulated by PRMS represents lateral subsurface flow through the soil matrix and is a function of the amount of water in the gravity reservoir. The pref_flow_den parameter partitions the amount of available soil-zone water in excess of the capillary reservoir storage capacity between the preferential-flow and gravity reservoirs. For the ONWM, parameters controlling fast and slow interflow were given higher values for HRUs with higher slopes, resulting in faster interflow for these HRUs.

\section{Land Cover}

Three land-cover parameters were used to define input parameters for the ONWM: (1) land-cover type, (2) percentage of imperviousness, and (3) percentage of canopy cover. The land-cover parameters were developed using the 2011 NLCD, which has a grid resolution of approximately 98 by $98 \mathrm{ft}$ (30 by $30 \mathrm{~m}$ ), or a grid-cell area of approximately 0.22 acres (900 square meters; Homer and others, 2015). In the case of land-cover type, the dominant NLCD cover type in each HRU was calculated using GIS. In PRMS, the parameter cov_type is used to specify five different land-cover types: (1) barren, (2) grassland, (3) shrubs, (4) deciduous forests, and (5) evergreen forests (Markstrom and others, 2015). The NLCD 2011 land-cover types were grouped into one of the five cover types used by PRMS (table 7).

The NLCD percentage of impervious land cover is defined as the percentage of each 0.22-acre grid cell covered by an artificial, impervious surface (for example, roadway, rooftop, or parking lot). The NLCD percentage of impervious land cover does not represent locations with relatively low permeability caused by exposed bedrock areas or areas that have thin soils underlain by low-permeability bedrock. These areas were represented in the ONWM using parameters defining soil and bedrock properties. The mean percentage of impervious land cover in each HRU was calculated and used directly as input to define values for the parameter hru_percent_imperv. Most of the HRUs in the ONWM (about 85 percent) had an NLCD impervious percentage value of 0 to 1 (fig. 12). Only about 1 percent of the HRUs had NLCD impervious percentage values of 50 percent or greater. In general, the HRUs with more impervious land cover (20 percent and higher) were along the main roadways and other areas where there were substantial urbanization and high-density land development. 
Table 7. Precipitation Runoff Modeling System parameters used in the Osage Nation watershed model (ONWM), Oklahoma and Kansas.

[deg., degree; dday, degree day; GIS, geographic information system; gm/ $\mathrm{cm}^{3}$; gram per cubic centimeter; >, greater than; NA, not applicable]

\begin{tabular}{|c|c|c|c|c|c|c|c|c|c|c|}
\hline \multirow{2}{*}{$\begin{array}{c}\text { PRMS } \\
\text { parameter name }\end{array}$} & \multirow{2}{*}{$\begin{array}{l}\text { PRMS } \\
\text { module }\end{array}$} & \multirow{2}{*}{$\begin{array}{l}\text { Parameter } \\
\text { group }\end{array}$} & \multirow{2}{*}{$\begin{array}{l}\text { Parameter } \\
\text { units }\end{array}$} & \multirow{2}{*}{$\begin{array}{l}\text { Dimension } \\
\text { name }\end{array}$} & \multirow{2}{*}{$\begin{array}{c}\text { Number of } \\
\text { values }\end{array}$} & \multicolumn{4}{|c|}{ Parameter } & \multirow{2}{*}{$\begin{array}{c}\text { Method used to } \\
\text { define value }\end{array}$} \\
\hline & & & & & & Type & Mean & Maximum & Minimum & \\
\hline albset_snm & snowcomp & Snow & Inches & one & 1 & Float & 0.22 & 0.22 & 0.22 & Previous studies \\
\hline potet_sublim & snowcomp & Snow & Decimal fraction & one & 1 & Float & 0.75 & 0.75 & 0.75 & Previous studies \\
\hline settle_const & snowcomp & Snow & Decimal fraction & one & 1 & Float & 0.11 & 0.11 & 0.11 & Previous studies \\
\hline albset_rna & snowcomp & Snow & Decimal fraction & one & 1 & Float & 0.81 & 0.81 & 0.81 & Previous studies \\
\hline albset_rnm & snowcomp & Snow & Decimal fraction & one & 1 & Float & 0.61 & 0.61 & 0.61 & Previous studies \\
\hline radadj_intcp & ddsolrad & Climate & dday & one & 1 & Float & 0.99 & 0.99 & 0.99 & Previous studies \\
\hline emis_noppt & snowcomp & Snow & Decimal fraction & one & 1 & Float & 0.7571 & 0.7571 & 0.7571 & Previous studies \\
\hline radj_sppt & ddsolrad & Climate & Decimal fraction & one & 1 & Float & 0.44 & 0.44 & 0.44 & Previous studies \\
\hline radj_wppt & ddsolrad & Climate & Decimal fraction & one & 1 & Float & 0.5 & 0.5 & 0.5 & Previous studies \\
\hline melt_force & snowcomp & Snow & Julian day & one & 1 & Integer & NA & 90 & 90 & Previous studies \\
\hline den_max & snowcomp & Snow & $\mathrm{gm} / \mathrm{cm}^{3}$ & one & 1 & Float & 0.61 & 0.61 & 0.61 & Previous studies \\
\hline melt_look & snowcomp & Snow & Julian day & one & 1 & Integer & NA & 90 & 90 & Previous studies \\
\hline radadj_slope & ddsolrad & Climate & dday/degrees Fahrenheit & one & 1 & Float & 0 & 0 & 0 & Previous studies \\
\hline radmax & ddsolrad & Climate & Decimal fraction & one & 1 & Float & 0.81 & 0.81 & 0.81 & Previous studies \\
\hline den_init & snowcomp & Snow & $\mathrm{gm} / \mathrm{cm}^{3}$ & one & 1 & Float & 0.11 & 0.11 & 0.11 & Previous studies \\
\hline albset_sna & snowcomp & Snow & Inches & one & 1 & Float & 0.05 & 0.05 & 0.05 & Previous studies \\
\hline cascade_tol & cascade & Snow & Decimal fraction & one & 1 & Float & 0.01 & 0.01 & 0.01 & Previous studies \\
\hline freeh2o_cap & snowcomp & Snow & Decimal fraction & one & 1 & Float & 0.05 & 0.05 & 0.05 & Previous studies \\
\hline tmax_allsnow & climate_hru_prms & Snow & Degrees Fahrenheit & one & 1 & Float & 32.5 & 32.5 & 32.5 & Previous studies \\
\hline tmax_allrain & climate_hru_prms & Climate & Degrees Fahrenheit & nmonth & 12 & Float & 40.5 & 40.5 & 40.5 & Previous studies \\
\hline adjmix_rain & climate_hru_prms & Climate & Decimal fraction & nmonth & 12 & Float & 1.516 & 2.315 & 0.0055 & Previous studies \\
\hline tstorm_mo & snowcomp & Climate & None & nmonth & 12 & Integer & NA & 1.00 & 0.00 & Previous studies \\
\hline tmax_index & ddsolrad & Climate & Degrees Fahrenheit & nmonth & 12 & Float & 50 & 50 & 50 & Previous studies \\
\hline jh_coef & potet $\mathrm{jh}$ & Climate & Per degrees Fahrenheit & nmonth & 12 & Float & 0.0135 & 0.0205 & 0.0097 & Calibrated \\
\hline ppt_rad_adj & ddsolrad & Climate & Inches & nmonth & 12 & Float & 0.02 & 0.02 & 0.02 & Previous studies \\
\hline cecn_coef & snowcomp & Snow & $\begin{array}{l}\text { Calories per deg. } \\
\text { Celsius }>0\end{array}$ & nmonth & 12 & Float & 5 & 5 & 5 & Previous studies \\
\hline dday_intep & ddsolrad & Climate & dday & nmonth & 12 & Float & -20.25 & -12 & -35 & Calibrated \\
\hline dday_slope & ddsolrad & Climate & dday/degrees Fahrenheit & nmonth & 12 & Float & 0.35 & 0.44 & 0.27 & Calibrated \\
\hline snarea_curve & snowcomp & Snow & Decimal fraction & ndeplval & 22 & Float & 0.58 & 1.00 & 0.05 & Previous studies \\
\hline segment_type & routing & Major streams & None & nsegment & 7,389 & Integer & NA & 1 & 1 & GIS-defined \\
\hline obsin_segment & basin & Major streams & None & nsegment & 7,389 & Integer & NA & 5.000 & 0.000 & GIS-defined \\
\hline
\end{tabular}


Table 7. Precipitation Runoff Modeling System parameters used in the Osage Nation watershed model (ONWM), Oklahoma and Kansas.-Continued

[deg., degree; dday, degree day; GIS, geographic information system; gm/ $\mathrm{cm}^{3}$; gram per cubic centimeter; >, greater than; NA, not applicable]

\begin{tabular}{|c|c|c|c|c|c|c|c|c|c|c|}
\hline \multirow{2}{*}{$\begin{array}{c}\text { PRMS } \\
\text { parameter name }\end{array}$} & \multirow{2}{*}{$\begin{array}{l}\text { PRMS } \\
\text { module }\end{array}$} & \multirow{2}{*}{$\begin{array}{l}\text { Parameter } \\
\text { group }\end{array}$} & \multirow{2}{*}{$\begin{array}{l}\text { Parameter } \\
\text { units }\end{array}$} & \multirow{2}{*}{$\begin{array}{c}\text { Dimension } \\
\text { name }\end{array}$} & \multirow{2}{*}{$\begin{array}{l}\text { Number of } \\
\text { values }\end{array}$} & \multicolumn{4}{|c|}{ Parameter } & \multirow{2}{*}{$\begin{array}{c}\text { Method used to } \\
\text { define value }\end{array}$} \\
\hline & & & & & & Type & Mean & Maximum & Minimum & \\
\hline tosegment & basin & Major streams & None & nsegment & 7,389 & Integer & NA & 7,389 & 0 & GIS-defined \\
\hline x_coef & muskingum & Major streams & Decimal fraction & nsegment & 7,389 & Float & 0 & 0 & 0 & Calibrated \\
\hline k_coef & muskingum & Major streams & Hours & nsegment & 7,389 & Float & 0.1 & 0.1 & 0.1 & Calibrated \\
\hline hru_type & basin & Model layout & None & nhru & 135,044 & Integer & NA & 1 & 1 & GIS-defined \\
\hline hru_segment & basin & Major streams & None & nhru & 135,044 & Integer & NA & 7,389 & 0 & GIS-defined \\
\hline hru_subbasin & subbasin & Model layout & None & nhru & 135,044 & Integer & NA & 27 & 1 & GIS-defined \\
\hline hru_area & basin & Model layout & Acres & nhru & 135,044 & Float & 39.54 & 39.54 & 39.54 & GIS-defined \\
\hline hru_elev & basin & Topography & Feet & nhru & 135,044 & Float & 954.3 & 1,626 & 555.1 & GIS-defined \\
\hline hru_slope & soltab & Topography & Decimal fraction & nhru & 135,044 & Float & 0.0469 & 0.2744 & 0.0 & GIS-defined \\
\hline hru_aspect & soltab & Topography & Angular degrees & nhru & 135,044 & Float & 177.8 & 360.0 & 0.0 & GIS-defined \\
\hline hru_lat & basin & Model layout & Angular degrees & nhru & 135,044 & Float & 36.6 & 37.59 & 35.83 & GIS-defined \\
\hline tmin_cbh_adj & climate_hru & Climate & Degrees Fahrenheit & nhru & 135,044 & Float & 0 & 0 & 0 & Previous studies \\
\hline tmax_cbh_adj & climate_hru & Climate & Degrees Fahrenheit & nhru & 135,044 & Float & 0 & 0 & 0 & Previous studies \\
\hline fastcoef_lin & soilzone & Soils & Fraction/day & nhru & 135,044 & Float & 0.2051 & 0.5248 & 0.001 & Calibrated \\
\hline fastcoef_sq & soilzone & Soils & None & nhru & 135,044 & Float & 0.1 & 0.1 & 0.1 & Calibrated \\
\hline slowcoef_lin & soilzone & Soils & Fraction/day & nhru & 135,044 & Float & 0.1136 & 0.4435 & 0.002 & Calibrated \\
\hline slowcoef_sq & soilzone & Soils & None & nhru & 135,044 & Float & 0.1190 & 0.8699 & 0.05 & Calibrated \\
\hline pref_flow_den & soilzone & Soils & Decimal fraction & nhru & 135,044 & Float & 0.0607 & 0.7217 & 0.0 & Calibrated \\
\hline cov_type & basin & Land cover & None & nhru & 135,044 & Integer & NA & 5 & 1 & GIS-defined \\
\hline covden_sum & basin & Land cover & Decimal fraction & nhru & 135,044 & Float & 0.2661 & 0.9401 & 0.005 & GIS-defined \\
\hline covden_win & basin & Land cover & Decimal fraction & nhru & 135,044 & Float & 0.1909 & 0.8601 & 0.005 & GIS-defined \\
\hline snow_intcp & intcp & Land cover & Inches & nhru & 135,044 & Float & 0.0168 & 0.125 & 0.005 & GIS-defined \\
\hline srain_intep & intcp & Land cover & Inches & nhru & 135,044 & Float & 0.0257 & 0.125 & 0.005 & GIS-defined \\
\hline wrain_intcp & intcp & Land cover & Inches & nhru & 135,044 & Float & 0.0257 & 0.125 & 0.005 & GIS-defined \\
\hline rad_trncf & snowcomp & Land cover & Decimal fraction & nhru & 135,044 & Float & 0.5 & 0.5 & 0.5 & Previous studies \\
\hline hru_percent_imperv & basin & Land cover & Decimal fraction & nhru & 135,044 & Float & 0.0176 & 0.9561 & 0.0 & GIS-defined \\
\hline imperv_stor_max & srunoff_smidx_casc & Land cover & Inches & nhru & 135,044 & Float & 0.0275 & 0.0275 & 0.0275 & GIS-defined \\
\hline soil_type & soilzone & Soils & None & nhru & 135,044 & Integer & NA & 3 & 1 & GIS-defined \\
\hline soil_rechr_init & soilzone & Soils & Inches & nhru & 135,044 & Float & 0.0957 & 0.4422 & 0.0178 & Estimated \\
\hline soil_rechr_max & soilzone & Soils & Inches & nhru & 135,044 & Float & 0.9570 & 4.422 & 0.1778 & Calibrated \\
\hline soil_moist_init & soilzone & Soils & Inches & nhru & 135,044 & Float & 0.4785 & 2.211 & 0.0889 & Estimated \\
\hline
\end{tabular}


[deg., degree; dday, degree day; GIS, geographic information system; gm/ $/ \mathrm{cm}^{3}$; gram per cubic centimeter; >, greater than; NA, not applicable]

\begin{tabular}{|c|c|c|c|c|c|c|c|c|c|c|}
\hline \multirow{2}{*}{$\begin{array}{c}\text { PRMS } \\
\text { parameter name }\end{array}$} & \multirow{2}{*}{$\begin{array}{l}\text { PRMS } \\
\text { module }\end{array}$} & \multirow{2}{*}{$\begin{array}{l}\text { Parameter } \\
\text { group }\end{array}$} & \multirow{2}{*}{$\begin{array}{l}\text { Parameter } \\
\text { units }\end{array}$} & \multirow{2}{*}{$\begin{array}{l}\text { Dimension } \\
\text { name }\end{array}$} & \multirow{2}{*}{$\begin{array}{l}\text { Number of } \\
\text { values }\end{array}$} & \multicolumn{4}{|c|}{ Parameter } & \multirow{2}{*}{$\begin{array}{l}\text { Method used to } \\
\text { define value }\end{array}$} \\
\hline & & & & & & Type & Mean & Maximum & Minimum & \\
\hline soil_moist_max & soilzone & Soils & Inches & nhru & 135,044 & Float & 4.785 & 22.11 & 0.8892 & Calibrated \\
\hline soil2gw_max & soilzone & Soils & Inches & nhru & 135,044 & Float & 0.007 & 0.05 & 0.0 & Calibrated \\
\hline sat_threshold & soilzone & Soils & Inches & nhru & 135,044 & Float & 2.393 & 11.06 & 0.4446 & Calibrated \\
\hline carea_max & srunoff_smidx & Topography & Decimal fraction & nhru & 135,044 & Float & 0.7037 & 0.9973 & 0.01 & Calibrated \\
\hline smidx_exp & srunoff_smidx & Topography & 1.0/inch & nhru & 135,044 & Float & 0.2845 & 0.6939 & 0.2 & Calibrated \\
\hline smidx_coef & srunoff_smidx & Topography & Decimal fraction & nhru & 135,044 & Float & 0.0335 & 0.1472 & 0.01 & Calibrated \\
\hline snarea_thresh & snowcomp & Snow & Inches & nhru & 135,044 & Float & 50.0 & 50.0 & 50.0 & Previous studies \\
\hline snowinfil_max & srunoff_smidx_casc & Snow & Inches/day & nhru & 135,044 & Float & 2.0 & 2.0 & 2.0 & Previous studies \\
\hline hru_deplcrv & snowcomp & Snow & None & nhru & 135,044 & Integer & NA & 1 & 1 & Previous studies \\
\hline transp_tmax & transp_tindex & Land cover & Degrees Fahrenheit & nhru & 135,044 & Float & 293.4 & 2,000 & 100.0 & Calibrated \\
\hline transp_beg & transp_tindex & Land cover & Month & nhru & 135,044 & Integer & NA & 12 & 1 & Calibrated \\
\hline transp_end & transp_tindex & Land cover & Month & nhru & 135,044 & Integer & NA & 13 & 11 & Calibrated \\
\hline jh_coef_hru & potet_jh & Climate & Degrees Fahrenheit & nhru & 135,044 & Float & 19.87 & 20.58 & 18.73 & GIS-defined \\
\hline dprst_area & basin & Water bodies & Acres & nhru & 135,044 & Float & 2.01 & 37.56 & 0.0 & GIS-defined \\
\hline dprst_depth_avg & srunoff_smidx & Water bodies & Inches & nhru & 135,044 & Float & 20.14 & 375.6 & 0.0 & GIS-defined \\
\hline dprst_et_coef & srunoff_smidx & Water bodies & Decimal fraction & nhru & 135,044 & Float & 1.0 & 1.0 & 1.0 & Previous studies \\
\hline dprst_flow_coef & srunoff_smidx & Water bodies & Fraction/day & nhru & 135,044 & Float & 0.05 & 0.05 & 0.05 & Calibrated \\
\hline dprst_frac_init & srunoff_smidx & Water bodies & Decimal fraction & nhru & 135,044 & Float & 0.05 & 0.05 & 0.05 & Previous studies \\
\hline dprst_frac_open & basin & Water bodies & Decimal fraction & nhru & 135,044 & Float & 1.0 & 1.0 & 1.0 & Previous studies \\
\hline dprst_seep_rate_clos & srunoff_smidx & Water bodies & Fraction/day & nhru & 135,044 & Float & 0.0022 & 0.01 & 0.0001 & Calibrated \\
\hline dprst_seep_rate_open & srunoff_smidx & Water bodies & Fraction/day & nhru & 135,044 & Float & 0.0022 & 0.01 & 0.0001 & Calibrated \\
\hline op_flow_thres & srunoff_smidx & Water bodies & Decimal fraction & nhru & 135,044 & Float & 1.0 & 1.0 & 1.0 & Previous studies \\
\hline sro_to_dprst & srunoff_smidx & Water bodies & Decimal fraction & nhru & 135,044 & Float & 0.5 & 0.5 & 0.5 & Calibrated \\
\hline sro_to_dprst_imperv & srunoff_smidx & Water bodies & Decimal fraction & nhru & 135,044 & Float & 0.5 & 0.5 & 0.5 & Calibrated \\
\hline va_clos_exp & srunoff_smidx & Water bodies & None & nhru & 135,044 & Float & 1.0 & 1.0 & 1.0 & Previous studies \\
\hline va_open_exp & srunoff_smidx & Water bodies & None & nhru & 135,044 & Float & 1.0 & 1.0 & 1.0 & Previous studies \\
\hline ssr2gw_rate & soilzone & Geology & Fraction/day & nssr & 135,044 & Float & 0.1099 & 0.5 & 0.005 & Calibrated \\
\hline ssstor_init & soilzone & Soils & Inches & nssr & 135,044 & Float & 0 & 0 & 0 & Estimated \\
\hline ssr2gw_exp & soilzone & Geology & None & nssr & 135,044 & Float & 1 & 1 & 1 & Calibrated \\
\hline gwsink_coef & gwflow & Geology & Fraction/day & ngw & 135,044 & Float & 0.3139 & 0.999 & 0.0 & Calibrated \\
\hline gwstor_init & gwflow & Geology & Inches & ngw & 135,044 & Float & 0.0220 & 0.1 & 0.001 & Estimated \\
\hline
\end{tabular}


Table 7. Precipitation Runoff Modeling System parameters used in the Osage Nation watershed model (ONWM), Oklahoma and Kansas.-Continued

[deg., degree; dday, degree day; GIS, geographic information system; gm/ $\mathrm{cm}^{3}$; gram per cubic centimeter; >, greater than; NA, not applicable]

\begin{tabular}{|c|c|c|c|c|c|c|c|c|c|c|}
\hline \multirow{2}{*}{$\begin{array}{c}\text { PRMS } \\
\text { parameter name }\end{array}$} & \multirow{2}{*}{$\begin{array}{l}\text { PRMS } \\
\text { module }\end{array}$} & \multirow{2}{*}{$\begin{array}{l}\text { Parameter } \\
\text { group }\end{array}$} & \multirow{2}{*}{$\begin{array}{l}\text { Parameter } \\
\text { units }\end{array}$} & \multirow{2}{*}{$\begin{array}{c}\text { Dimension } \\
\text { name }\end{array}$} & \multirow{2}{*}{$\begin{array}{c}\text { Number of } \\
\text { values }\end{array}$} & \multicolumn{4}{|c|}{ Parameter } & \multirow{2}{*}{$\begin{array}{l}\text { Method used to } \\
\text { define value }\end{array}$} \\
\hline & & & & & & Type & Mean & Maximum & Minimum & \\
\hline gwflow_coef & gwflow & Geology & Fraction/day & ngw & 135,044 & Float & 0.497 & 0.9 & 0.4050 & Calibrated \\
\hline gwstor_min & gwflow & Geology & Inches & ngw & 135,044 & Float & 0 & 0 & 0 & Previous studies \\
\hline hru_strmseg_down_id & cascade & Major streams & None & ncascade & 135,044 & Integer & NA & 7,389 & 0 & GIS-defined \\
\hline hru_down_id & cascade & Cascades & None & ncascade & 135,044 & Integer & NA & 135,044 & 46,339 & GIS-defined \\
\hline hru_up_id & cascade & Cascades & None & ncascade & 135,044 & Integer & NA & 135,044 & 1 & GIS-defined \\
\hline hru_pct_up & cascade & Cascades & Decimal fraction & ncascade & 135,044 & Float & 1.0 & 1.0 & 1.0 & GIS-defined \\
\hline gw_strmseg_down_id & cascade & Major streams & None & ncascdgw & 135,044 & Integer & NA & 7,389 & 0 & GIS-defined \\
\hline gw_down_id & cascade & Cascades & None & ncascdgw & 135,044 & Integer & $\mathrm{NA}$ & 135,044 & 46,339 & GIS-defined \\
\hline gw_up_id & cascade & Cascades & None & ncascdgw & 135,044 & Integer & NA & 135,044 & 1 & GIS-defined \\
\hline gw_pct_up & cascade & Cascades & Decimal fraction & ncascdgw & 135,044 & Float & 1.0 & 1.0 & 1.0 & GIS-defined \\
\hline rain_cbh_adj & climate_hru & Climate & Decimal fraction & nhru & $1,620,528$ & Float & 1.0 & 1.0 & 1.0 & Previous studies \\
\hline snow_cbh_adj & climate_hru & Climate & Decimal fraction & nhru & $1,620,528$ & Float & 1.0 & 1.0 & 1.0 & Previous studies \\
\hline gvr_cell_id & map_results & Model layout & None & nhrucell & 135,044 & Integer & NA & 264,504 & 7,103 & GIS-defined \\
\hline gvr_cell_pct & map_results & Model layout & Decimal fraction & nhrucell & 135,044 & Float & 1.0 & 1.0 & 1.0 & GIS-defined \\
\hline gvr_hru_id & map_results & Model layout & None & nhrucell & 135,044 & Integer & NA & 135,044 & 1 & GIS-defined \\
\hline
\end{tabular}


As with the percentage of impervious land cover, the percentage of canopy cover represented by the NLCD is defined on a 98 -by-98-ft (30-by-30 m) grid cell spacing as the percentage of the 0.22 -acre (900 square meter) cell area covered by natural forest canopy. The NLCD forestcanopy map does not represent vegetation cover for urban or agricultural landscapes and does not represent natural vegetation cover for shrubland and grassland areas. The mean percentage of canopy cover was calculated for the 39.54-acre area of each HRU. PRMS input parameters used to represent summer vegetation cover for the ONWM, covden_sum, and winter vegetation cover, covden_win, were defined using a combination of the dominant NLCD land-cover type (fig. 11) and the mean NLCD forest-canopy percentage (fig. 13) for each HRU. A mean canopy cover of 30 percent was calculated for the ONWM, including a maximum of 83 percent canopy cover for an HRU in the southeastern part of the ONWM area and minimum values of 0 percent for large areas in the northern and western parts of the ONWM area, where grasslands dominate.

\section{Soils}

Soil properties were estimated for each model cell by using the SSURGO digital map and associated attribute tables with GIS applications (Natural Resources Conservation Service, 2006). The estimated SSURGO soil properties were used in conjunction with other GIS datasets, such as the NED topography and the NLCD land cover, to develop initial estimates of PRMS parameters representing soil properties. The parameters representing the soil properties were adjusted during stages 3 and 4 of the model-calibration described in the "Model Calibration" section of this report.

A total of 200 different soil types, or soil map units defined by SSURGO, were included in the ONWM area. For each soil map unit identifier (MUID), estimates of soil texture (percentages of sand, silt, and clay), soil thickness, hydrologic group (A, B, C, and D), hydraulic conductivity, porosity, and field capacity were defined using a weighted-mean or dominant-component calculation based on the fraction of soil components by area in each MUID area and the number and thickness of soil layers for each soil component. The estimated soil properties were used to develop initial estimates of PRMS parameters representing soil properties.

For example, estimates of soil thickness and field capacity were used to develop initial estimates of the soil_moist_max parameter in PRMS. The soil_moist_max parameter defines the total soil-zone water-storage capacity of the capillary reservoir, as a depth for each HRU area, according to the estimated rootzone thickness and soil-field capacity. Initial estimates of soil_moist_max developed using SSURGO were refined using additional GIS datasets; soil_moist_max was decreased with increasing slope, increased with increasing NLCD forest canopy cover, and either increased or decreased depending on the NLCD dominant land cover or vegetation type. Additional parameters defining the soil-zone storage capacities, soil_rechr_max and sat_threshold, were also estimated using a combination of soil properties from SSURGO and NLCD land cover.

The carea_max parameter controls Hortonian runoff generation and was initially estimated using land-surface slope, such that greater carea_max values were defined

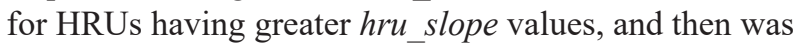
modified according to the dominant hydrologic soil group, the percentage of clay, and the soil hydraulic conductivity estimated using SSURGO. Additional parameters controlling the rate of Hortonian runoff generation compared to infiltration, smidx_coef and smidx_expf, were also estimated using hru_slope and the estimated soil hydraulic conductivity using SSURGO.

\section{Geology}

Parameters controlling the rate of recharge to the groundwater reservoir, the rate of discharge to stream channels, and the rate of groundwater losses to saturated zone ET, pumping, and basin underflow were defined using the mapped surface geology (fig. 16). The $s s r 2 g w$ rate parameter controls the rate of recharge to the groundwater reservoir underlying each HRU. The gwflow_coef is a base-flow recession-curve coefficient and controls the rate of groundwater discharge to stream segments (or, in the case of cascading flow, the rate of groundwater flow to the downstream groundwater reservoir) as a function of the amount of water in the groundwater reservoir. The gwsink_coef controls the rate of groundwater loss from the groundwater reservoir to the inactive groundwater reservoir, also referred to as the groundwater sink. In the conceptual model used for the ONWM, the groundwater sink accounts for all groundwater that does not contribute directly to groundwater discharge to stream segments, also referred to as base flow. In the ONWM, the groundwater sink was used to represent components of the groundwater system that cannot be simulated by PRMS-IV and includes the combined outflows fromET (in areas of shallow water tables), pumping, and groundwater underflow, as well as increases in stored groundwater in the inactive groundwater reservoir.

The generalized rock types represented by the surfacegeology map were used to develop the initial estimates for these parameters, which were then adjusted during model calibration. Estimates of greater bedrock and alluvium hydraulic conductivity were used to set higher initial estimates for all three parameters (ssr2gw_rate, gwflow_coef, and gwsink_coef) and lower hydraulic conductivity was used to set lower values. During model calibration, adjustments to the parameters were made in such a way that the relative difference in values was generally maintained in order to preserve the spatial distribution of the estimated bedrock and alluvium hydraulic conductivities. 


\section{Water Bodies}

Water bodies are represented in the ONWM using the depression-storage module in PRMS. The depression-storage model simulates inflows, outflows, and changes in storage for the water bodies associated with the HRUs. Inflows include surface runoff and interflow from upstream HRUs, precipitation, and groundwater discharge. Outflows include evaporation, surface-water discharge, and seepage into the underlying groundwater reservoir. The surface-water inflows and outflows include overland flow and interflow components.

The dprst_area parameter defines the maximum area of depression storage in each HRU, and the dprst_depth_avg parameter defines the mean depth of the depressions in the HRU. Estimates for dprst_area and dprst_depth_avg were developed using the mapped areas of water bodies (table 7; fig. 17); dprst_area ranged from 0 to 37.56 acres, and dprst depth_avg ranged from 0 inch $(0 \mathrm{ft})$ to 375.6 inches $(31.3 \mathrm{ft})$.

All depressions represented in the ONWM were defined as open depressions, and therefore, the parameter dprst frac open was set to a constant value of 1 (table 7). In PRMS, open depressions allow for surface-water outflows as a function of the parameter op flow thres defining the threshold water depth, as a fraction of dprst_depth avg, at which surfacewater overflows. The $o p_{-}$flow_thres value was set to 1.0 for all depressions (table 7). Unlike open depressions, closed depressions do not allow for surface-water outflows. Although not used by the ONWM, parameters used to define properties for closed depressions, va_clos_exp and dprst_seep_rate_clos, were set to PRMS default values (table 7).

The relative fraction of impervious and pervious depression storage areas for a given HRU was defined using the value of hru percent_imperv for that HRU. Simulated processes for impervious depressions included inflows from precipitation and overland flow and outflows from evaporation and surface-water overflow. The sro to dprst parameter defined the fraction of HRU surface runoff diverted both to pervious and impervious depression storage for each HRU and was set to a uniform value of 0.5 (table 7). The sro_to_dprst_ imperv parameter controlled the fraction of the HRU surface runoff diverted to the impervious depression and was also set to a uniform value of 0.5 for all depressions (table 7).

The open, pervious depressions used in the ONWM to simulate water bodies allowed for inflows from interflow and groundwater discharge in addition to surface runoff from the HRU containing the depression. The parameter dprst_flow_coef was used to simulate the rate of surface-water outflow from depression storage as a function of water depth exceeding the maximum depth defined by dprst_depth_avg and $o p$ flow_thres. The open, pervious depressions also allowed for water seepage into the underlying groundwater reservoir. The parameter dprst_seep_rate_open was used to simulate the rate of groundwater seepage. Seepage from depression storage contributed to the total recharge, which also included recharge simulated as infiltration through the soil zone. Many of the parameters used to simulate depression storage were initially estimated using values from previous studies as well as default or suggested values provided in the PRMS-IV documentation (Markstrom and others, 2015) and then were adjusted as part of the model calibration. A complete description of the parameters used in the depressionstorage module of PRMS-IV is provided in Markstrom and others (2015).

\section{Major Streams}

Major stream channels were represented in the ONWM by PRMS stream segments (fig. 20). Streamflow was routed from upstream to downstream segments using the Muskingum module in PRMS-IV (Markstrom and others, 2015). In addition to the routing connections between contributing HRUs and stream segments and between upstream and downstream stream segments, input parameters required by the Muskingum module included the $x \_c o e f$ and $k$ _coef parameters (table 7). The $x$ ccoef parameter was used to represent stream-segment length, and the $k$ _coef parameter was used to control the time delay in the downstream propagation of the floodwave. In the ONWM layout, a single stream segment was assigned to each of the 7,389 HRUs containing a major stream channel. Using this configuration, the lengths of all stream segments were approximately uniform. The $x$ _coef parameter was set to an initial value of 0.0 , and the $k$ _coef parameter was set to an initial value of 0.1 hours for all stream segments (table 7). The $x \_c o e f$ and $k_{-}$coef parameter values were evaluated as part of the model calibration process.

\section{Climate Inputs}

Climate inputs used for the ONWM consisted of three components: (1) daily precipitation, (2) daily maximum air temperature, and (3) daily minimum air temperature. The climate inputs were defined using a preprocessing routine (Hevesi and others, 2011a; Woolfenden and Nishikawa, 2014), whereby a unique daily time series of the three climate inputs was generated for all HRUs using spatial interpolation methods and available climate records from a network of climate stations centered on the ONWM. The preprocessing routine required estimates of mean monthly precipitation and mean monthly maximum and minimum air temperatures for all model cells and all climate stations. In the ONWM, the climate_hru module in PRMS was used, whereby the three climate inputs ( 1 file for each component) were stored in three separate input files, with each file containing a unique daily time series of the respective climate inputs for each HRU. 


\section{Daily Precipitation and Air Temperature}

Records of daily precipitation and maximum and minimum daily air temperature were available from a network of 203 climate stations centered on the ONWM area (table 3). A spatial-interpolation method was used to estimate daily precipitation and maximum and minimum daily air temperature for all HRUs (Hevesi and others, 2011a; Woolfenden and Nishikawa, 2014; Hevesi and Christensen, 2015). The method used to develop gridded estimates of mean monthly precipitation and maximum and minimum air temperatures was described previously in the "Climate" section.

\section{Mean Monthly Precipitation and Air Temperature}

Daily precipitation and maximum and minimum air temperatures were spatially interpolated for each HRU using a modified inverse-distance-squared interpolation (Hevesi and others, 2011b; Flint and Martin, 2012; Woolfenden and Nishikawa, 2014; Hevesi and Christensen, 2015). The interpolation method required estimates of mean monthly precipitation and mean monthly maximum and minimum air temperatures at all HRUs and at all climate stations with records used in the interpolation. The PRISM data (Daly and others, 1994, 2004) were used to define the estimates of mean monthly precipitation and mean monthly maximum and minimum air temperatures for HRUs and climate stations. The PRISM data used in the ONWM consisted of mean monthly precipitation and mean monthly maximum and minimum air temperatures developed for the conterminous United States using an approximate grid resolution of 2,625 $\mathrm{ft}(800 \mathrm{~m})$ for the 30-year period from 1981 to 2010 (Daly and others, 1994, 2004). The mean monthly PRISM estimates incorporated multiple variables in order to account for complex orographic effects on precipitation and air temperature, such as rain shadows, adiabatic cooling, average storm trajectory, and distance from moisture sources (Daly and others, 1994, 2004).

\section{River Inflows}

Daily river inflows, specified as a boundary condition at the five tributary inflow locations along the western ONWM boundary (figs. 1, 2; table 2), were needed for simulating the inflow boundary condition for the ONIHM area in order to account for the total streamflow in the Arkansas River. The five river inflows were (1) the Arkansas River, (2) the
Cimarron River, (3) the Walnut River, (4) the Chikaskia River, and (5) the Salt Fork of the Arkansas River, and were included in the ONWM as continuous daily mean streamflows at each of the five stream segments defined as inflows on the ONWM boundary. The five inflows were defined using daily streamflow records available at seven USGS streamgages:

(1) Arkansas River at Arkansas City, KS (ARKA), (2) Walnut River at Winfield, KS (WALW), (3) Salt Fork Arkansas River at Tonkawa, OK (SFAT), (4) Chikaskia River near Blackwell, OK (CHIB), (5) Cimarron River near Guthrie, OK (CIMG), (6) Cimarron River at Perkins, OK (CIMP), and (7) Cimarron River near Ripley, OK (CIMR) (fig. 2; table 2). Four of the streamgages, ARKA, WALW, SFAT, and CHIB, had continuous daily records beginning at water year 1938 or earlier and were used directly as input to the ONWM. The record for the fifth streamgage, CIMG on the Cimarron River, was relatively short; therefore, an extended record of daily streamflow was developed using the maintenance of variance estimation, 1st-order (MOVE1; Hirsch, 1982) method and records of daily mean streamflow from two streamgages, CIMP and CIMR, upstream from streamgage CIMG on the Cimarron River (fig. 2; table 2).

River inflows were not required for the ONWM simulations used to simulate the 100 -year water budget for water years 1915-2014. In this study, the simulated 100-year water budget was used to analyze the redistribution of water over the land surface and in the shallow subsurface in response to the daily climate inputs (precipitation and maximum and minimum air temperature) in the ONWM area. The analyzed 100-year water-budget components included ET, surface-water storage, subsurface-water storage, recharge, surface runoff, interflow, base flow, and groundwater losses. These waterbudget components were independent of the river inflows.

In addition to simulating the inflows to the ONIHM area, the river inflows were also needed for calibration of the ONWM using the streamflow records for two streamgages on the Arkansas River, ARKR and ARKT (table 2). The daily river inflows were subtracted from the daily streamflows for streamgages ARKR and ARKT (table 2) to develop a local record of observed streamflows more representative of the daily inflows generated from the contributing drainage areas upstream from each streamgage and within the ONWM area. The developed local records of observed inflows for each streamgage from the ONWM contributing area were considered appropriate for model calibration because these calculated flows corresponded more directly to the flows simulated by the ONWM. 


\section{Model Calibration}

Precipitation-runoff models, such as PRMS (Jeton, 1999; Koczot and others, 2005; Markstrom and others, 2008; Jeton and Maurer, 2011), the USGS INFILtration model code INFILv3 (Hevesi and others, 2003; Rewis and others, 2006; Hevesi and Christensen, 2015), and Hydrologic Simulation Program-FORTRAN (HSPF; Donigian and others, 1984; Hevesi and others, 2011b), require calibration by comparing simulated variables to values determined directly from measurements or to values estimated from field measurements. Measured or estimated values used for calibration are often referred to as observed values. Preferably, the observed variable of interest has continuous records at the desired temporal resolution spanning multi-year periods that capture a full range of conditions and variability, with at least one drier than average period and one wetter than average period. In most cases, calibration of precipitation-runoff models is primarily based on comparisons of time series of simulated and observed streamflow, where the observed streamflow record was determined from continuous measurements of stream stage, velocity, or both used with stage-discharge rating curves fitted to field measurements of stage and discharge or velocity and discharge over a wide range of flows. Simulated streamflow is usually the most important variable to calibrate precipitation-runoff models such as PRMS, because streamflow accounts for the integrated effects of the hydrologic processes in the drainage area upstream from the streamgage used for calibration.

In addition to using streamflow records, the ONWM was calibrated using continuous daily and monthly records of three other observed variables: short wave radiation (SWRAD), PET, and soil moisture. Calibration to observed SWRAD and PET was considered important because simulated SWRAD directly affects simulated PET, PET strongly effects simulated ET, and ET tends to be a substantial and critical component of the simulated water balance. Simulated soil moisture is also an important component of the water balance; however, soil moisture tends to be more difficult to use for calibration because measured values are representative of localized, sitespecific conditions.

\section{Calibration Procedure}

Calibration was done in four sequential stages using comparison of simulated and observed values: stage one was used for SWRAD, stage two was used for PET, stage three was used for soil moisture, and stage four was used for streamflow. In the model calibration procedure, parameters with a moderate to high degree of uncertainty and having a moderate to strong effect on the variables of interest were adjusted iteratively using a trial-and-error approach, until an acceptable fit between the simulated and observed variable was achieved.

Stage one consisted of a comparison between simulated and observed SWRAD. In the PRMS setup used for ONWM, SWRAD is simulated according to the day of the year; HRU latitude; land-surface slope, aspect, and elevation; and monthly parameters defining atmospheric conditions (Markstrom and others, 2015). Parameters adjusted during stage one were the monthly parameters dday_slope and dday_ intcp. Stage two consisted of fitting simulated PET to observed PET by adjusting the monthly parameter $j h \_$coef. Stage three consisted of fitting simulated to observed root-zone water content (expressed as a water-content fraction) by adjusting parameters defining the soil-zone storage capacity (soil_moist max, soil_sat_theshold, soil_rechr_max) and two parameters controlling transpiration (transp_beg and transp_end). Stage four consisted of fitting simulated to observed streamflow by adjusting a variety of parameters controlling surface runoff, interflow, ET, recharge, groundwater discharge to streams (sometimes referred to as base flow), and groundwater losses (also referred to as the groundwater sink). Parameters used in the Muskingum routing module in PRMS that control the propagation and dampening of peak flows, $x \_$coef and $k \_c o e f$, were also adjusted during stage four. Parameters that were calibrated in stages one (for SWRAD) and two (for PET) were held constant for the remaining stages. As described later in the "Stage-Four Calibration: Streamflow" section, the parameters calibrated in stage three for simulating soil moisture were not held fixed for the stage-four calibration.

Data records used for calibration were from two data sources: (1) 14 OCS Mesonet stations in the ONWM area (Oklahoma Climatological Survey, 2013; fig. 21; table 3) with continuous daily records of SWRAD, PET, and soil moisture, with most records starting in 1994, and (2) 22 USGS streamgages in the ONWM area with continuous streamflow records of daily mean streamflow (fig. 21; table 2). Records of soil moisture at 13 OCS Mesonet stations contained data at four different depth intervals and included estimates of water content by volumetric fraction for each depth interval (Illston and others, 2007). The USGS streamgages used for calibration had continuous daily mean streamflow records of variable lengths that spanned different periods (fig. 22; table 2). The earliest streamflow record used for calibration began April 1, 1934, for streamgage COUS (USGS 07163000 Council Creek near Stillwater, OK). The longest period used for calibration was the 76-year record for streamgage BIRS (USGS 07177500 Bird Creek near Sperry, OK) that began with water year 1939 and ended with water year 2014. The shortest period used for calibration was the approximate 5-year record for streamgage HOMH (USGS 07176950 Hominy Creek near Hominy, OK) that included records from October 1, 2003, to September 29, 2007, and June 30, 2013, to September 30, 2014. 


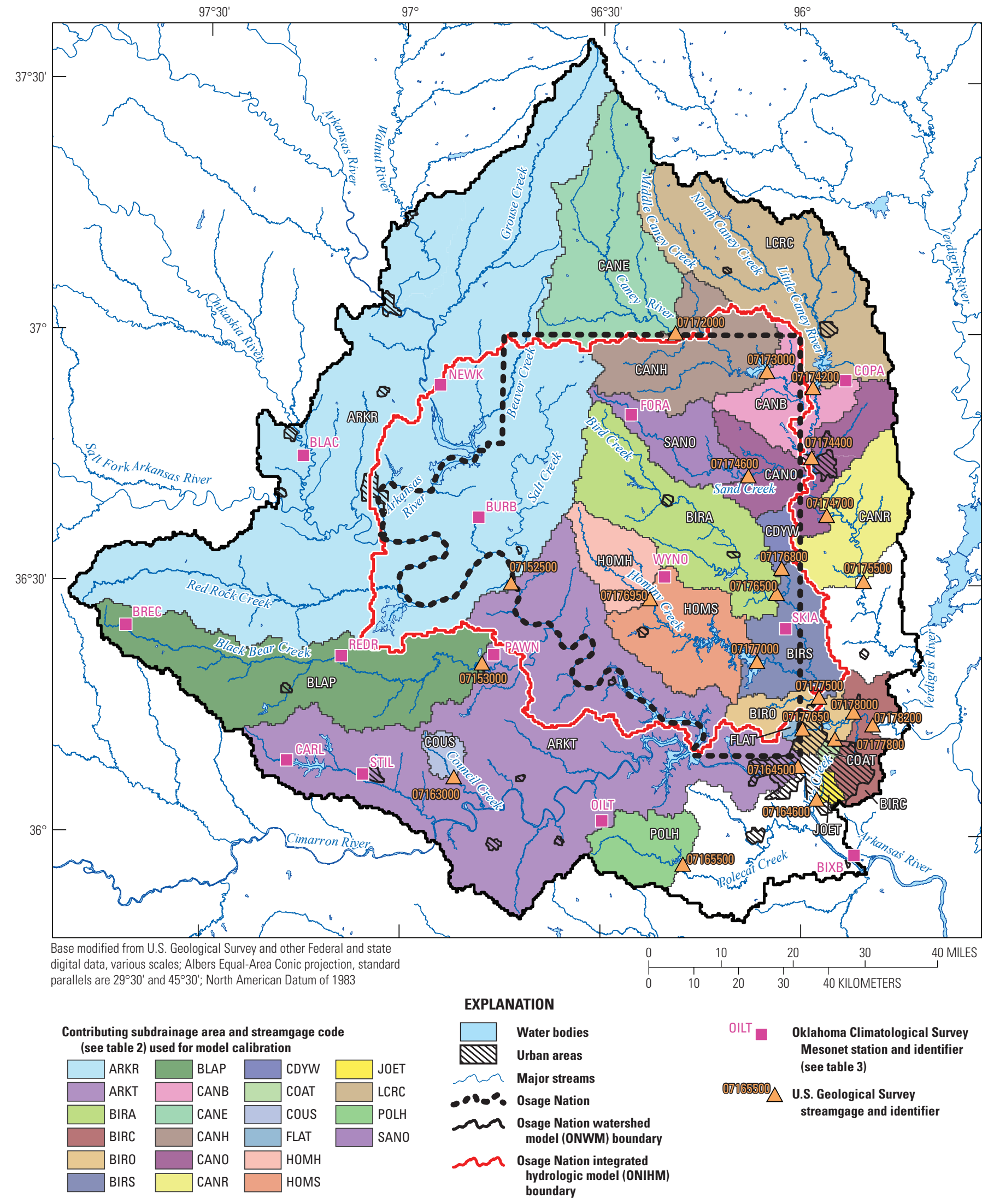

Figure 21. Oklahoma Climatological Survey Mesonet stations and U.S. Geological Survey streamgages and associated subdrainages used for model calibration, Osage Nation watershed model, Oklahoma and Kansas. 


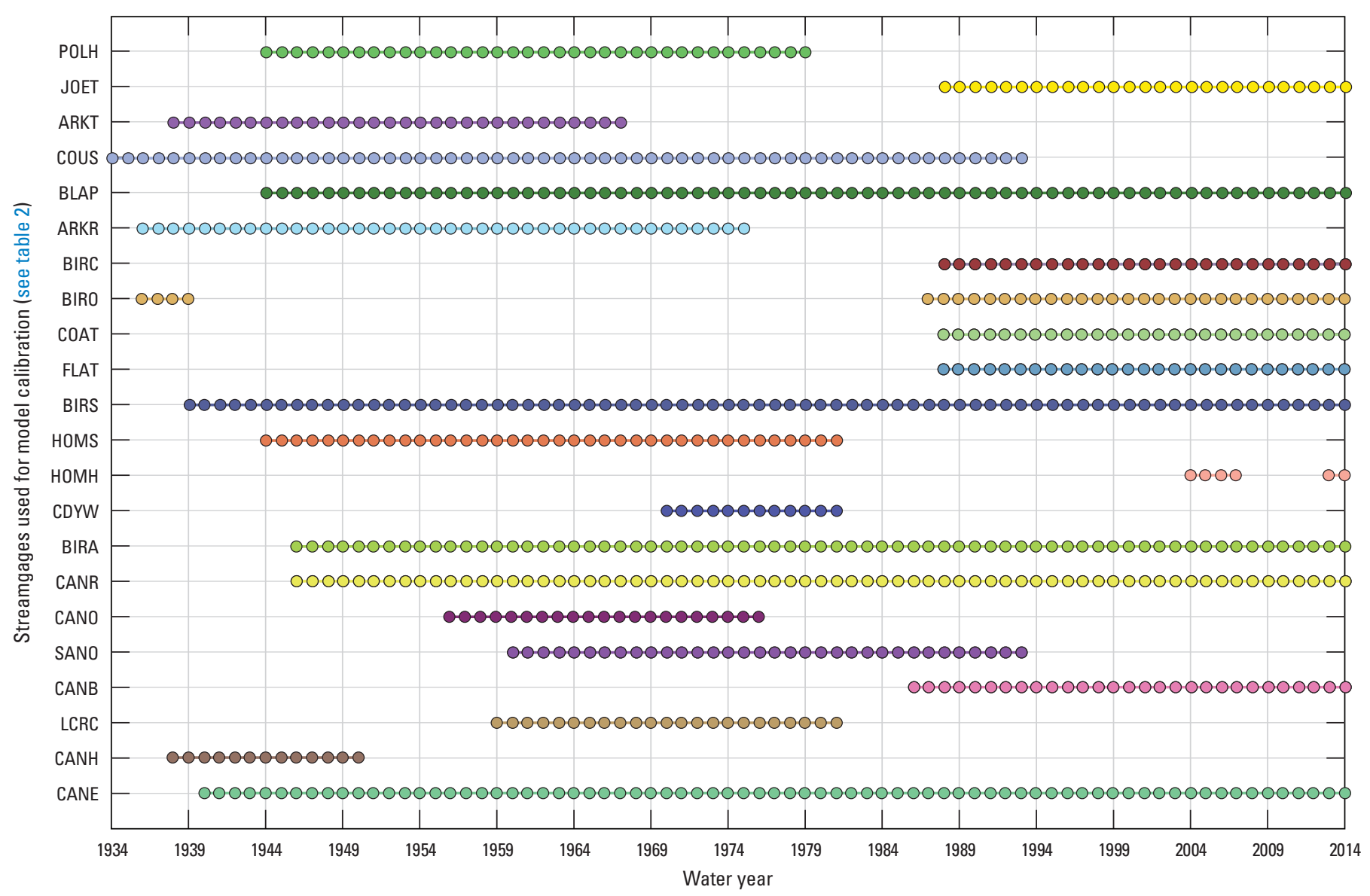

Figure 22. Water years having streamflow records for 22 U.S. Geological Survey streamgages used for model calibration, 0sage Nation watershed model, Oklahoma and Kansas.

The calibration procedure for all stages included a quantitative analysis of the goodness-of-fit between simulated and observed time series and was done using the percentaverage estimation error (PAEE) and the Nash-Sutcliffe model efficiency (NSME) statistics (Nash and Sutcliffe, 1970; Woolfenden and Nishikawa, 2014). The PAEE statistic provides a measure of model bias, where a value of 0.0 percent indicates an unbiased model fit. Values of PAEE in the range of plus or minus 10 percent are usually considered to indicate a good fit (Donigian, 2009) (https://www.aquaterra. com/resources/pubs/pdf/donigian-2009c.pdf). The NSME statistic is a standardized mean squared-error statistic that is often used to compare results between different models (Nash and Sutcliffe, 1970; Markstrom and others, 2008). An NSME value greater than 0.0 indicates the model provides a better match to the observed values than the mean of the observed values. The closer the NSME is to 1.0, the better the match is between simulated and observed values, with a value of 1.0 indicating a perfect match. For this study, an NSME of 0.4 or greater was considered a satisfactory calibration for daily results, a value of 0.6 or greater indicated a satisfactory calibration for monthly results, and a value of 0.7 indicated a satisfactory calibration for annual results.

\section{Stage-One Calibration: Short Wave Radiation (SWRAD)}

Stage-one calibration consisted of comparing simulated SWRAD to observed SWRAD at 14 OCS Mesonet sites in the ONWM area that had 79 to 249 months (about 7 to 21 years) of daily SWRAD records (tables 3, 8). In the ONWM, SWRAD is simulated by PRMS and is used by PRMS to simulate PET and snowmelt. The ONWM uses the "ddsolrad" module in PRMS to simulate SWRAD using inputs for the HRU latitude, HRU slope, HRU aspect, day of the year, and monthly atmospheric parameters (Markstrom and others, 2015). The ddsolrad module also uses the daily precipitation and air-temperature inputs to estimate reductions in SWRAD in response to cloud cover (Markstrom and others, 2015). The parameters affecting simulated SWRAD that were adjusted during the trial-and-error calibration were the monthly parameters dday_slope and dday_intcp. A total of 24 values (12 monthly values for each parameter) were adjusted during calibration. Comparisons were done using daily, monthly, annual, and mean monthly results (fig. 23). 
Results for Mesonet station BIXB (table 8) provided an example of the goodness-of-fit between simulated and observed SWRAD (fig. 23). The daily results for BIXB indicated the seasonal variation in SWRAD, with the simulated daily mean values showing slightly lower maximums and slightly higher minimums compared to the observed daily mean values, but provided a good general match to observed daily values ranging from about 100 langleys to about 700 langleys (fig. $23 \mathrm{~A}$ ). The monthly mean time series indicated a good fit between simulated and observed SWRAD, with monthly values ranging from less than 200 langleys to more than 600 langleys (fig. 23B). The annual mean results indicated a good match between simulated and observed SWRAD for water years 1994 and 2006, the two partial water years with missing daily records for the months of October through December, as well as a satisfactory general fit to the year-to-year variations in SWRAD (fig. $23 C$ ). Annual results with low SWRAD values did not match as well; the simulated values indicated 2014 was the water year with lowest average SWRAD, whereas the observed values indicated water year 2004 was the year with the lowest SWRAD. The scatterplot of simulated and observed monthly SWRAD (fig. 23D), as well as the mean monthly results (fig. 23E), indicated a good overall match between the simulated and observed values at station BIXB.

Goodness-of-fit statistics for monthly values indicated a good model fit at all stations using the final adjusted monthly values for dday_slope and dday_intcp, with a PAEE within 5 percent and NSME values of 0.92 to 0.95 (table 8). The scatterplot of the monthly results for all 14 stations indicated a close match to the 1-to-1 line (fig. 24A), and the comparison of mean monthly results using the mean values at all stations also indicated a good match between simulated and observed SWRAD (fig. 24B). The highest mean monthly SWRAD was approximately 600 langleys for simulated and observed values at station CARL for June (fig. 24A). The lowest mean monthly simulated SWRAD was 173 langleys at station FORA for December. The observed mean monthly SWRAD for December was 190 langleys at station FORA. For all stations, the highest mean monthly values for simulated and observed SWRAD were for June and July, and the lowest mean monthly values for simulated and observed SWRAD were for December (fig. 24B).

Table 8. Goodness-of-fit results using simulated and observed monthly short-wave radiation, Osage Nation watershed model (ONWM), Oklahoma and Kansas.

[NSME, Nash-Sutcliffe model efficiency; PAEE, percent average estimation error; —, not applicable]

\begin{tabular}{|c|c|c|c|c|c|c|c|c|c|}
\hline \multirow[t]{2}{*}{$\begin{array}{c}\text { Mesonet climate } \\
\text { station }\end{array}$} & \multirow{2}{*}{$\begin{array}{l}\text { Number } \\
\text { of months } \\
\text { analyzed }\end{array}$} & \multicolumn{3}{|c|}{$\begin{array}{c}\text { Observed monthly } \\
\text { short-wave radiation } \\
\text { (langleys) }\end{array}$} & \multicolumn{3}{|c|}{$\begin{array}{l}\text { Simulated monthly } \\
\text { short-wave radiation } \\
\text { (langleys) }\end{array}$} & \multicolumn{2}{|c|}{$\begin{array}{l}\text { Goodness-of-fit } \\
\text { statistics }\end{array}$} \\
\hline & & Mean & Maximum & Minimum & Mean & Maximum & Minimum & PAEE & NSME \\
\hline BIXB & 246 & 387 & 621 & 153 & 402 & 667 & 121 & 3.8 & 0.93 \\
\hline BLAC & 248 & 394 & 639 & 153 & 396 & 680 & 122 & 0.5 & 0.94 \\
\hline BREC & 240 & 405 & 671 & 163 & 401 & 680 & 136 & -0.8 & 0.94 \\
\hline CARL & 79 & 415 & 662 & 180 & 416 & 681 & 166 & 0.3 & 0.95 \\
\hline COPA & 20.3 & 385 & 636 & 145 & 377 & 665 & 111 & -2.1 & 0.94 \\
\hline FORA & 240 & 390 & 643 & 155 & 375 & 661 & 109 & -4.1 & 0.92 \\
\hline NEWK & 240 & 393 & 644 & 160 & 384 & 662 & 123 & -2.4 & 0.93 \\
\hline SKIA & 240 & 386 & 639 & 143 & 378 & 664 & 110 & -2.0 & 0.94 \\
\hline STIL & 240 & 391 & 640 & 156 & 409 & 683 & 147 & 4.6 & 0.93 \\
\hline WYNO & 240 & 392 & 640 & 145 & 387 & 671 & 109 & -1.3 & 0.94 \\
\hline Weighted mean ${ }^{1}$ & - & 392 & 643 & 154 & 394 & 673 & 124 & 2.3 & 0.93 \\
\hline
\end{tabular}

${ }^{1}$ Weights were calculated for each station as the number of months analyzed divided by 3,306 , the total number of months analyzed for all stations. The weighted mean is the sum of the value for each station multiplied by the station weight for each station. The PAEE weighted mean is calculated using the absolute PAEE value for each station. 
$\boldsymbol{A}$

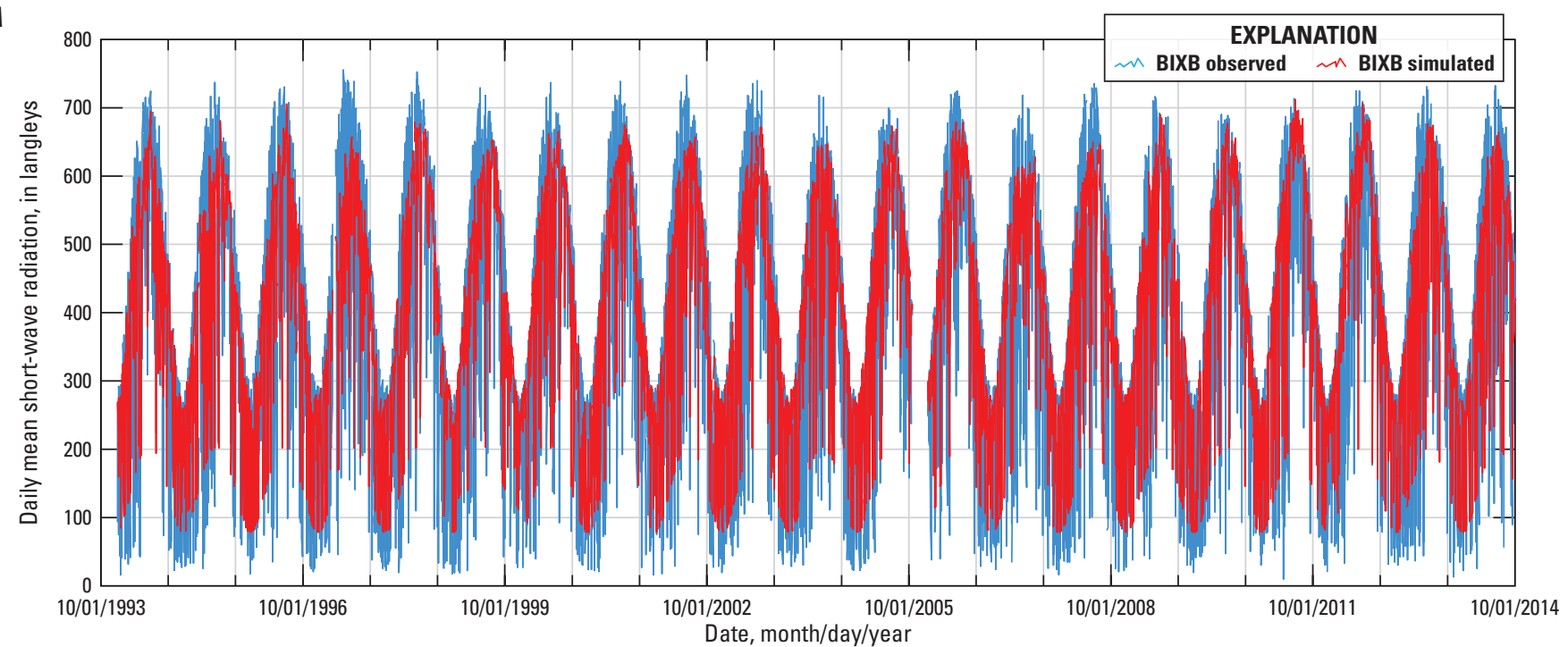

B

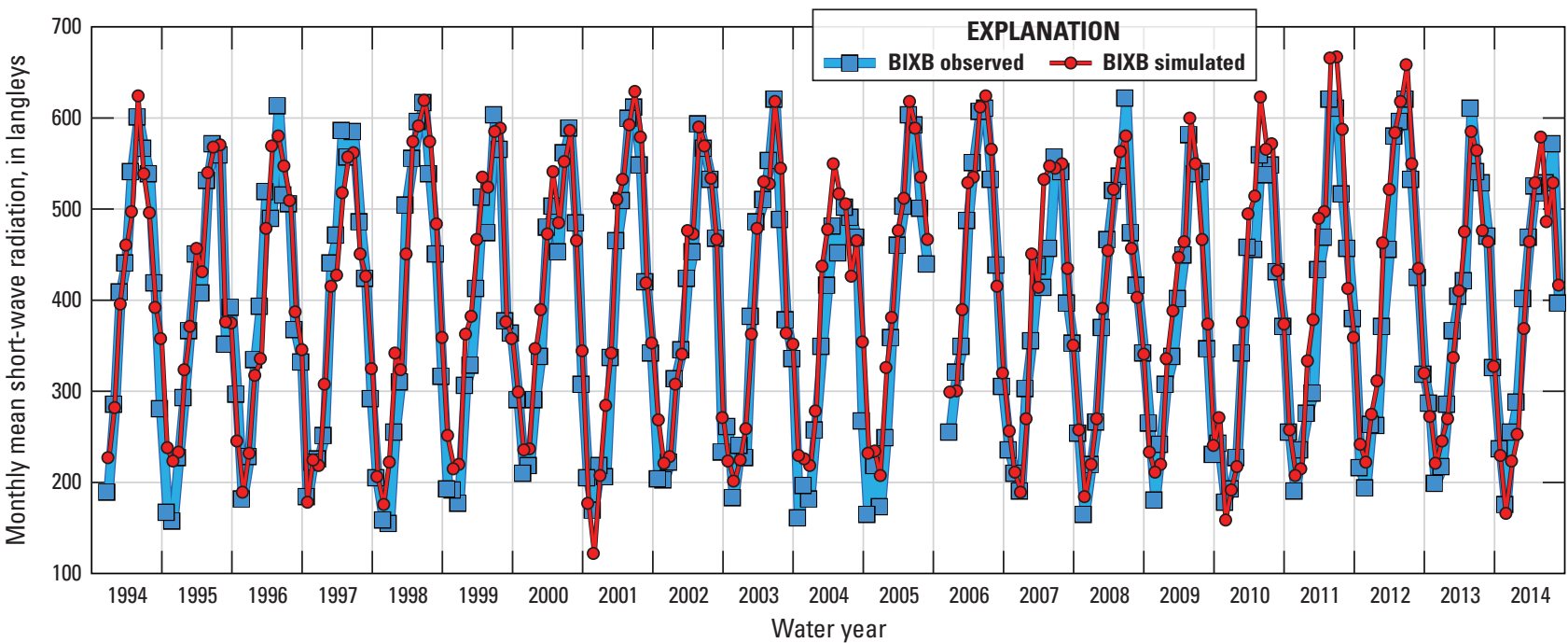

C

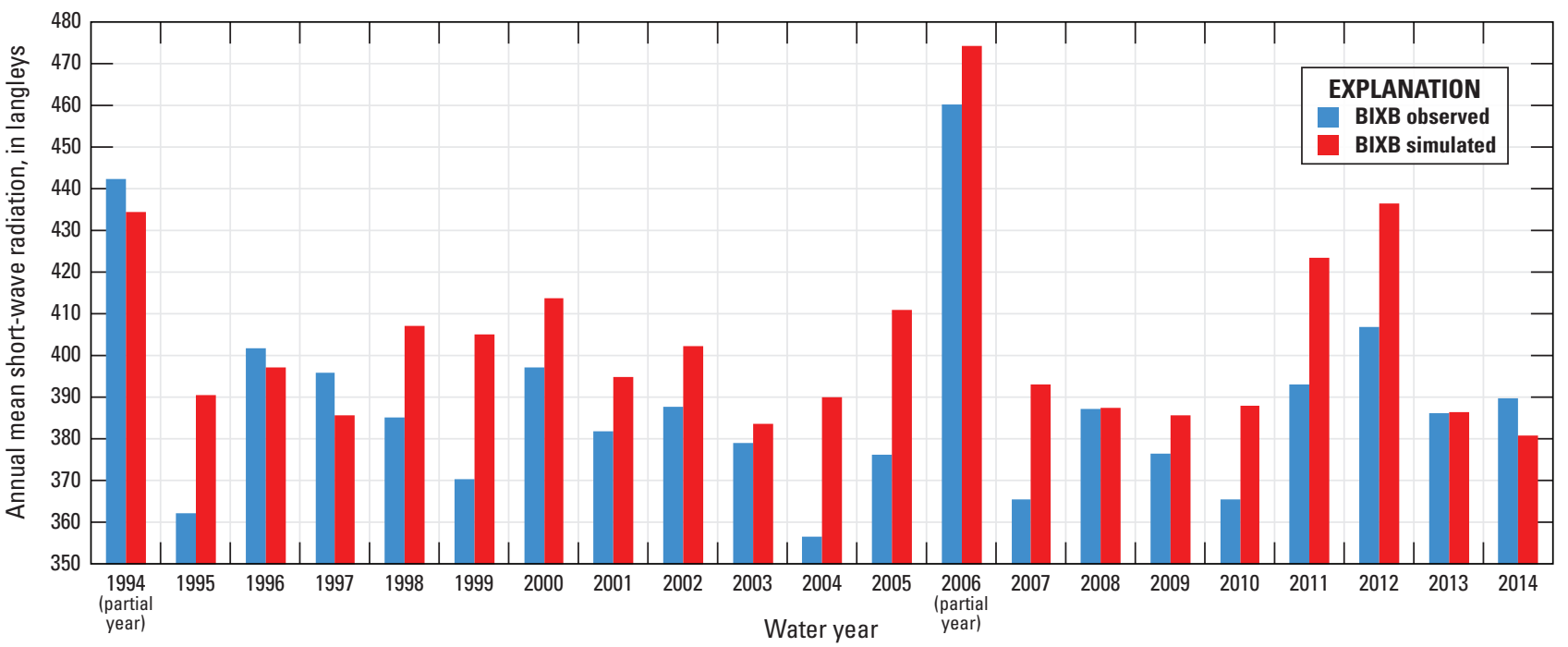

Figure 23. Comparison of simulated short-wave radiation at Mesonet station BIXB, using the Osage Nation watershed model, Oklahoma and Kansas, with observed values using $A$, daily mean time series; $B$, monthly mean time series; $C$, annual mean time series; $D$, monthly mean scatterplot; and $E$, mean monthly results. 

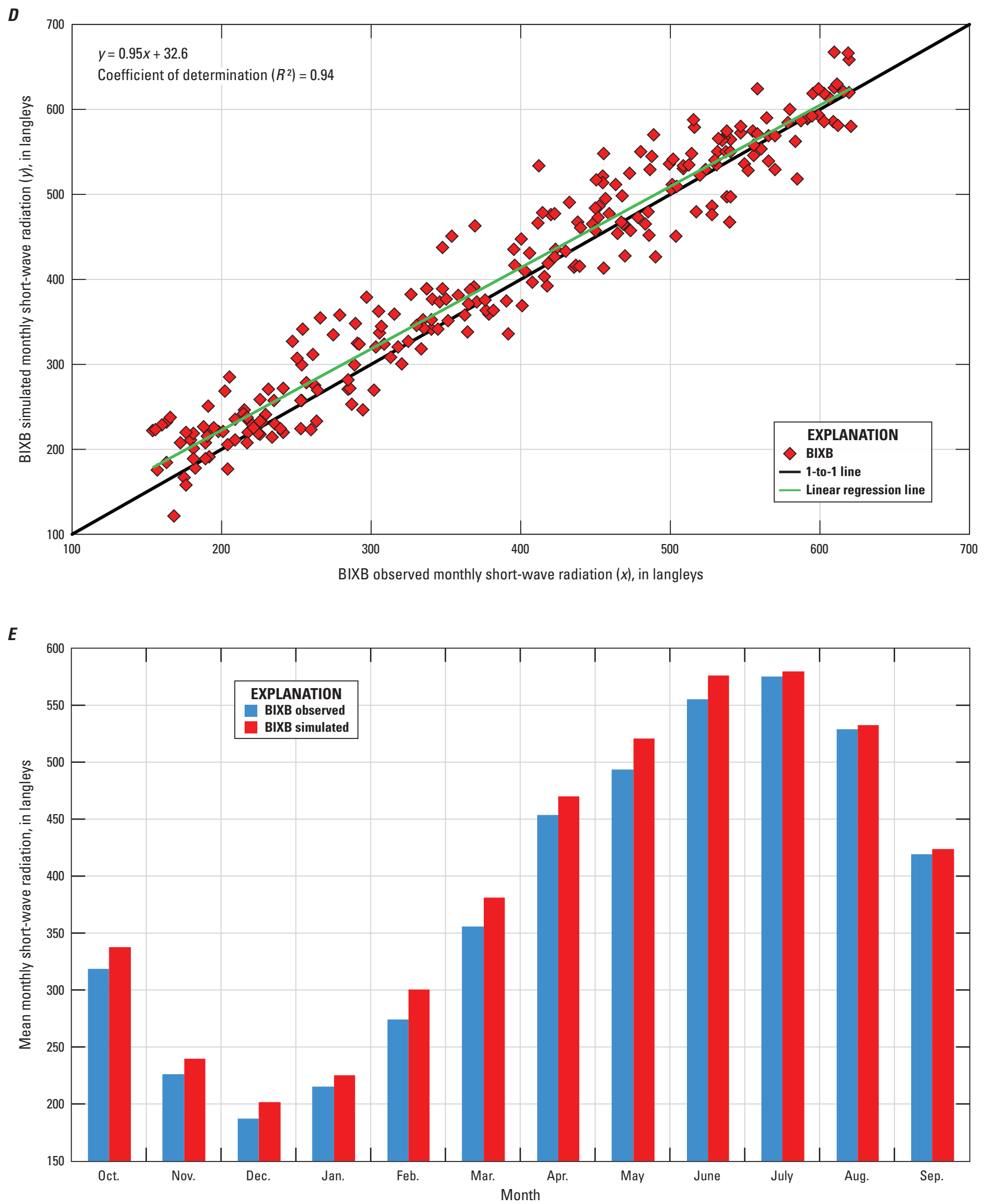

Figure 23. - Continued 

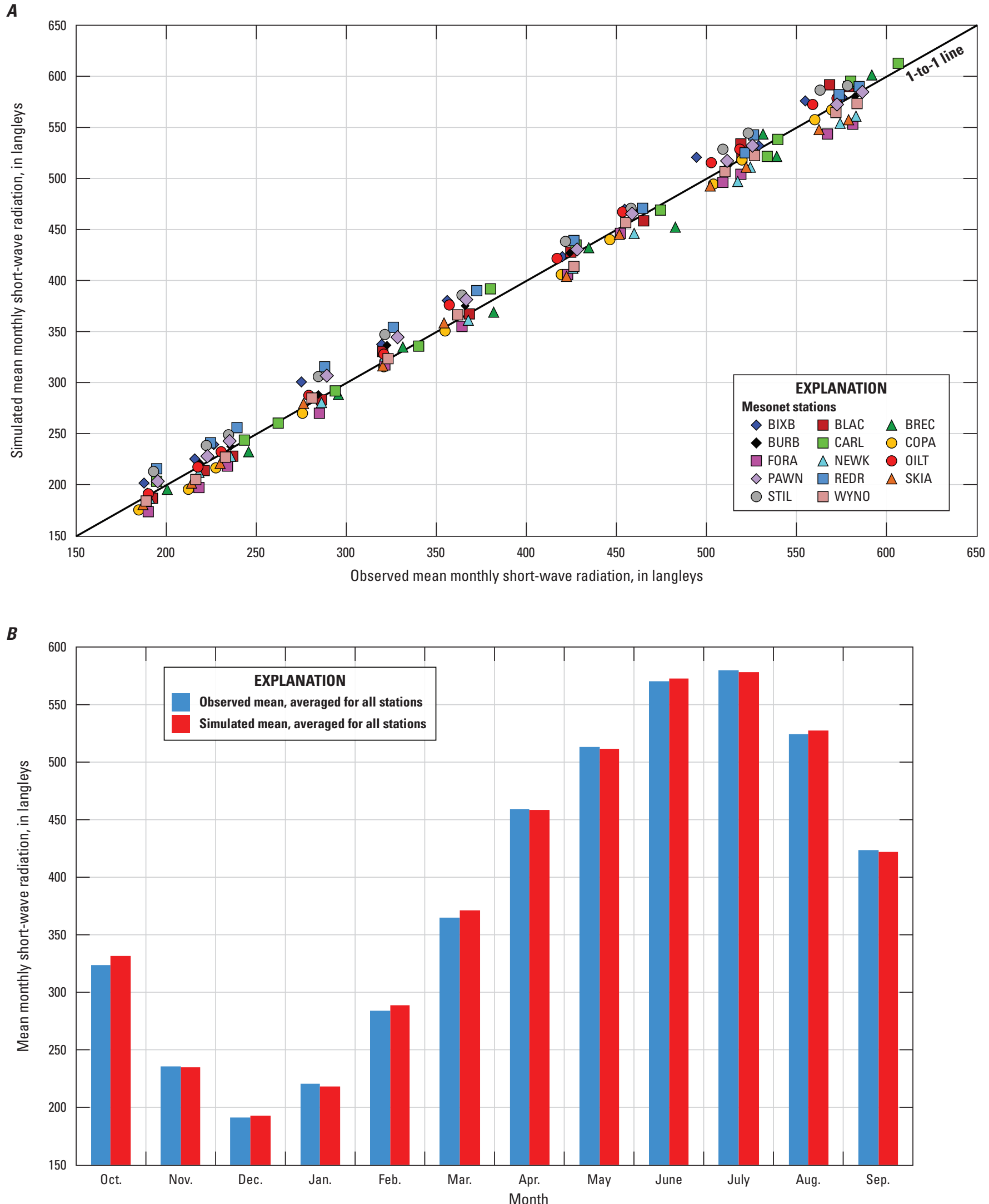

Figure 24. Comparison between simulated and observed short-wave radiation (SWRAD) at 14 Oklahoma Climatological Survey Mesonet stations for the Osage Nation watershed model, Oklahoma and Kansas: $A$, scatterplot of mean monthly values for all stations, and $B$, mean monthly results, averaged for all stations. 


\section{Stage-Two Calibration: Potential Evapotranspiration (PET)}

Stage-two calibration was done by comparing simulated to observed PET at the 14 OCS Mesonet sites for which there were 79 to 211 months (6.6 to 17.6 years) of records for measured daily PET (tables 3,9$)$. The observed PET values were field estimates of PET that were calculated using energy balance methods and the site-specific measurements of field conditions collected at the OCS Mesonet stations. In practice, PET estimated using measurements of field conditions is a reference ET rate $\left(E T_{\mathrm{o}}\right)$ calculated using a reference crop or grass height. For this study, the $E T_{\mathrm{o}}$ estimates used for calibration were based on a standard short-grass reference crop, and $E T_{\mathrm{o}}$ was referred to as PET.

The ONWM used the "potet_jh" module in PRMS to simulate PET using simulated SWRAD and the maximum and minimum daily air temperature inputs (Markstrom and others, 2015). The parameter affecting simulated PET that was adjusted during the trial and error calibration was the monthly parameter $j h$ coef (table 7). All 12 monthly values of the $j h$ coef parameter were manually adjusted during the trial-and-error calibration. The dday_slope and dday_intcp parameters that were calibrated during stage one calibration were held fixed during the stage-two calibration. The parameter $j h \_c o e f h r u$ (table 7), also used as input for the potet_jh module to simulate PET, was not adjusted during calibration, but rather was calculated for all HRUs using land-surface elevation and monthly maximum air temperature from PRISM.

Results for Mesonet station COPA (tables 3, 9) provide an example of the goodness-of-fit comparison (fig. 25). The daily results for COPA indicated seasonal variations in daily PET ranging from minimum values of approximately 0 inch per day (in/day) for simulated and observed values to maximum simulated values of about $0.35 \mathrm{in} /$ day and maximum observed values as high as $0.44 \mathrm{in} /$ day (fig. $25 \mathrm{~A}$ ). The monthly time-series results indicated a good fit to the seasonal variation in PET; maximum monthly values were about 9 inches, and minimum values were about 1 inch for simulated and observed values (fig. 25B). The annual time series also indicated a good match between simulated and observed PET; the simulated values were a good fit to the observed year-to-year variation at station COPA (fig. 25C). The scatterplot of simulated against observed monthly PET (fig. 25D) indicated a good fit of the simulated values to the 1-to-1 correlation line, with a coefficient of determination $\left(R^{2}\right)$ of 0.96 for the linear regression line between simulated and observed monthly PET (fig. 25D). The mean monthly results indicated a very good match between simulated and observed values; maximum monthly PET was about 7 inches for July for simulated and observed values, and a minimum monthly PET was about 1.5 inches for December for simulated and observed values (fig. 25E).

Table 9. Goodness-of-fit results using simulated and observed monthly potential evapotranspiration (PET), Osage Nation watershed model (ONWM), Oklahoma and Kansas.

[NSME, Nash-Sutcliffe model efficiency; PAEE, percent average estimation error; - , not applicable]

\begin{tabular}{|c|c|c|c|c|c|c|c|c|c|}
\hline \multirow[t]{2}{*}{$\begin{array}{l}\text { Mesonet climate } \\
\text { station }\end{array}$} & \multirow{2}{*}{$\begin{array}{l}\text { Number } \\
\text { of months } \\
\text { analyzed }\end{array}$} & \multicolumn{3}{|c|}{$\begin{array}{c}\text { Observed monthly potential } \\
\text { evapotranspiration } \\
\text { (inches) }\end{array}$} & \multicolumn{3}{|c|}{$\begin{array}{c}\text { Simulated monthly potential } \\
\text { evapotranspiration } \\
\text { (inches) }\end{array}$} & \multicolumn{2}{|c|}{$\begin{array}{l}\text { Goodness-of-fit } \\
\text { statistics }\end{array}$} \\
\hline & & Mean & Maximum & Minimum & Mean & Maximum & Minimum & PAEE & NSME \\
\hline BLAC & 209 & 4.38 & 10.0 & 1.0 & 4.38 & 9.8 & 0.5 & 0.0 & 0.96 \\
\hline BREC & 211 & 4.72 & 11.1 & 1.1 & 4.50 & 9.9 & 0.7 & -4.8 & 0.93 \\
\hline CARL & 79 & 4.57 & 9.2 & 1.2 & 4.63 & 9.8 & 1.1 & 1.4 & 0.96 \\
\hline COPA & 209 & 4.20 & 9.4 & 1.0 & 4.06 & 9.1 & 0.4 & -3.3 & 0.95 \\
\hline FORA & 206 & 4.19 & 9.0 & 1.0 & 4.00 & 9.0 & 0.4 & -4.6 & 0.94 \\
\hline NEWK & 206 & 4.41 & 10.1 & 1.0 & 4.10 & 9.0 & 0.5 & -7.1 & 0.93 \\
\hline OILT & 211 & 4.07 & 9.3 & 0.9 & 4.36 & 9.5 & 0.6 & 7.1 & 0.92 \\
\hline STIL & 211 & 4.27 & 9.4 & 0.9 & 4.56 & 9.9 & 0.7 & 6.9 & 0.93 \\
\hline WYNO & 206 & 4.35 & 9.7 & 1.1 & 4.23 & 9.4 & 0.5 & -2.9 & 0.94 \\
\hline Weighted mean ${ }^{1}$ & - & 4.32 & 9.6 & 1.0 & 4.32 & 9.5 & 0.6 & 3.6 & 0.94 \\
\hline
\end{tabular}



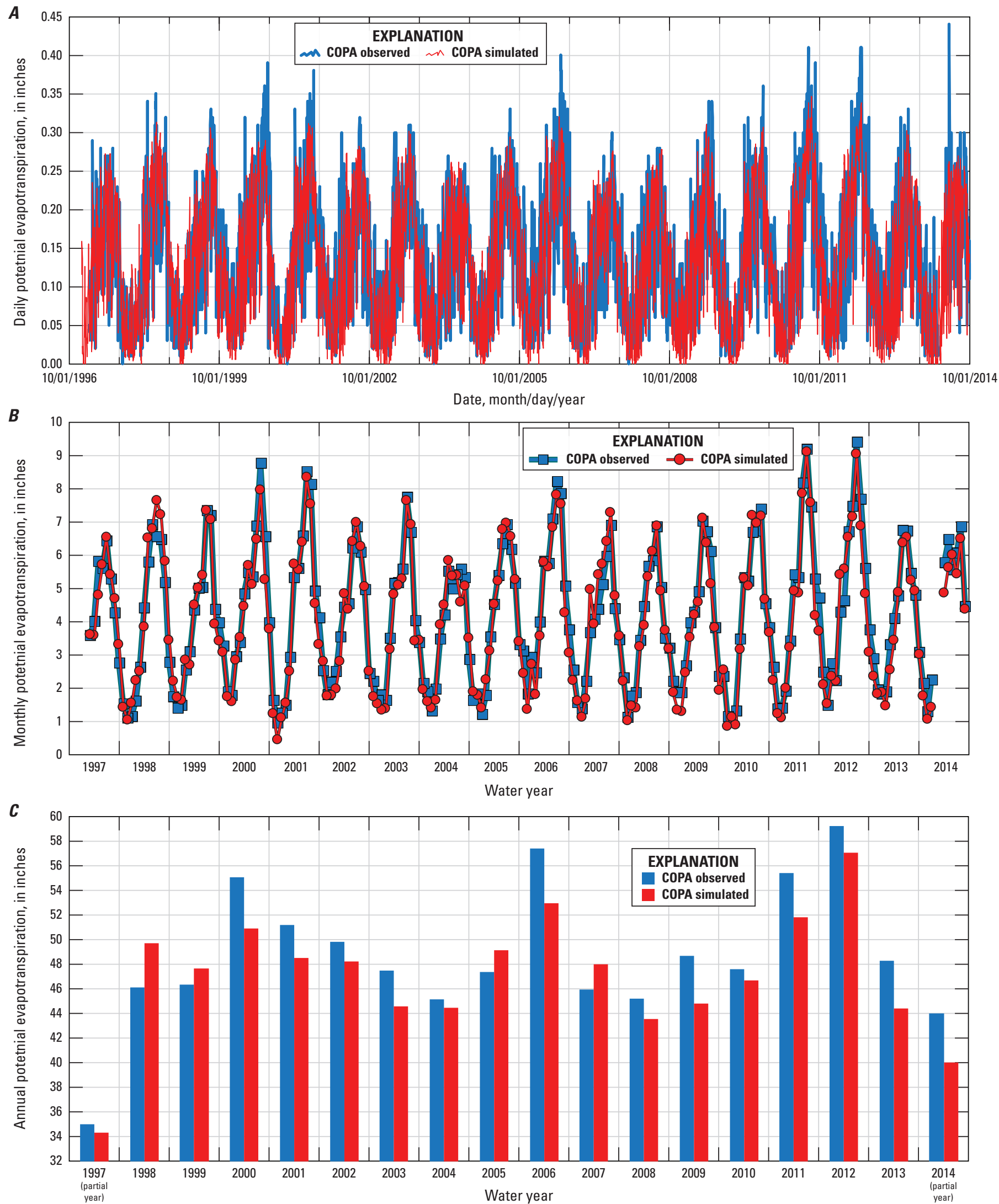

Figure 25. Comparison between simulated and observed potential evapotranspiration (PET) at station COPA using the 0sage Nation watershed model, Oklahoma and Kansas: $A$, daily time series; $B$, monthly time series; $C$, annual time series; $D$, monthly scatterplot; and $E$, mean monthly results. 

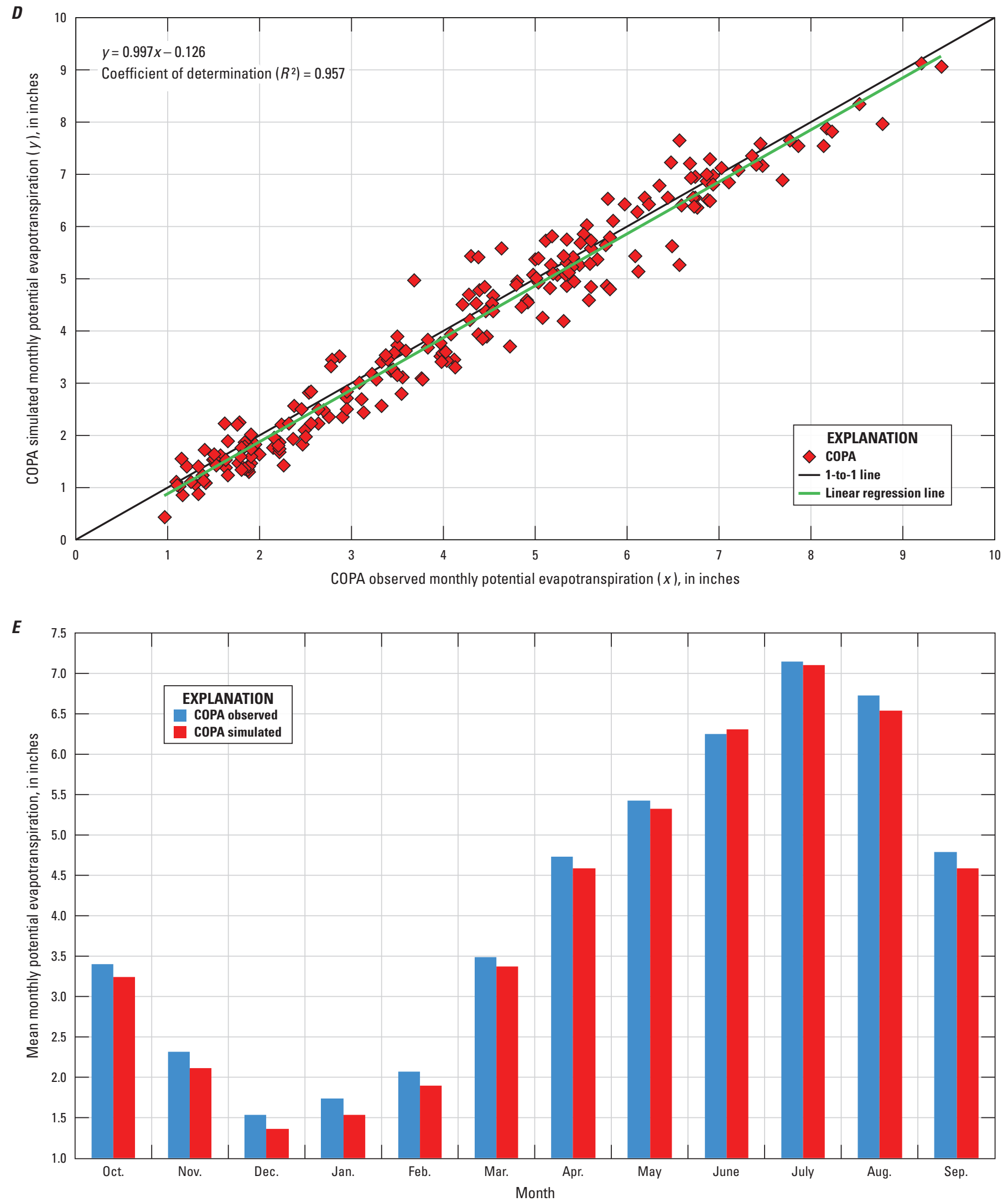

Figure 25. -Continued 
Goodness-of-fit statistics were calculated for PET using monthly simulated and observed values for all 14 stations (table 9). The results indicated a good model fit using the final adjusted monthly values for $j h \_c o e f$, with PAEE values ranging from 7.4 to -7.1 percent and NSME values ranging from 0.92 to 0.96 (table 9). The scatterplot of the mean monthly results for all 14 stations indicated a close match to the 1-to-1 line (fig. 26A), and the comparison of mean monthly results using the mean values at all stations also indicated a good match between simulated and observed PET (fig. 26B). The highest mean monthly values were about 7.4 inches for simulated and observed PET for July, and the lowest mean monthly values were about 1.6 inches for simulated and observed PET for December (fig. 26B).

The parameters calibrated in stages one and two of the calibration were held fixed for the remaining stages of model calibration. The SWRAD and PET components of the ONWM calibration were finalized with the completion of stage two. Using the calibrated model, PET was simulated for water years 1915-2014. The 100-year mean PET for the ONWM area was $51.7 \mathrm{in} / \mathrm{yr}$; higher values of 55.1-59 in/yr were simulated for south-facing slopes in the warmer, southern parts of the ONWM, and lower values of 45-47 in/yr were simulated for the north-facing slopes in the cooler, northern parts of the ONWM (fig. 27). For all of the ONWM area, the mean PET was greater than the mean precipitation rate (fig. 3). The results indicated a strong, local-scale effect of topography (elevation, slope, and aspect) on the simulated PET values, as well as the regional-scale effects of latitude and average air temperature on the spatial distribution of PET.

Simulated annual PET, averaged for the ONWM area, ranged from a minimum of about $44 \mathrm{in} / \mathrm{yr}$ for water year 1915 to a maximum of about $60 \mathrm{in} / \mathrm{yr}$ for water year 1954 (fig. 28A). The results for the LOWESS and the cumulative departure from mean annual PET indicated that PET tended to be higher prior to water year 1957, with an extended period of higher than average PET for water years 1930-39 (fig. 28B). The mean monthly PET distribution indicated that, except for November and December, monthly PET tended to exceed monthly precipitation (fig. 5). The maximum monthly PET of about 7.4 inches was simulated for July and was more than twice the mean precipitation of 3.1 inches simulated for July (fig. 5). 

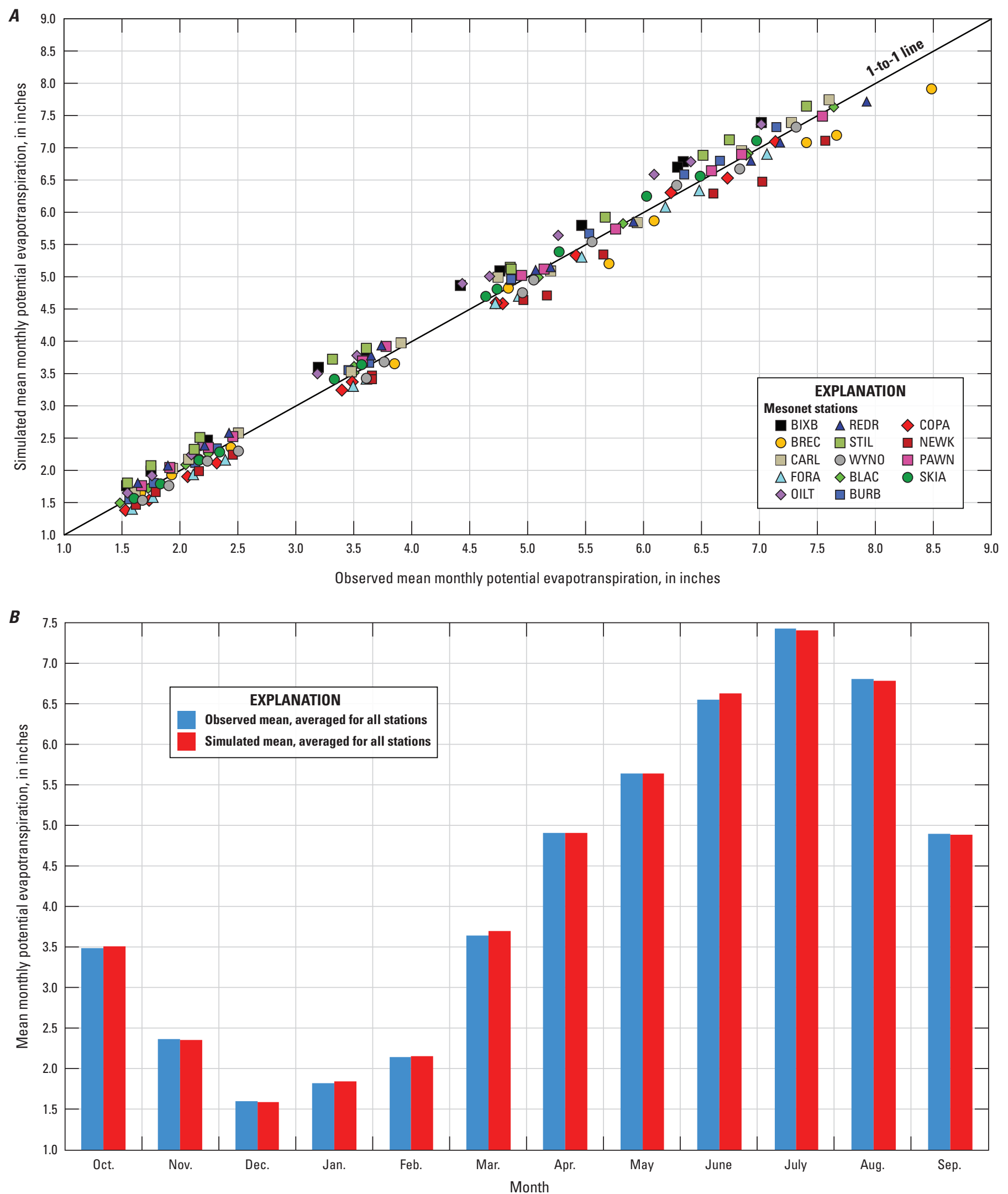

Figure 26. Comparison of simulated and observed potential evapotranspiration at 14 Oklahoma Climatological Survey Mesonet stations, the Osage Nation Watershed Model, Oklahoma and Kansas: $A$, scatterplot of mean monthly values for all stations, and $B$, mean monthly results, averaged for all stations. 


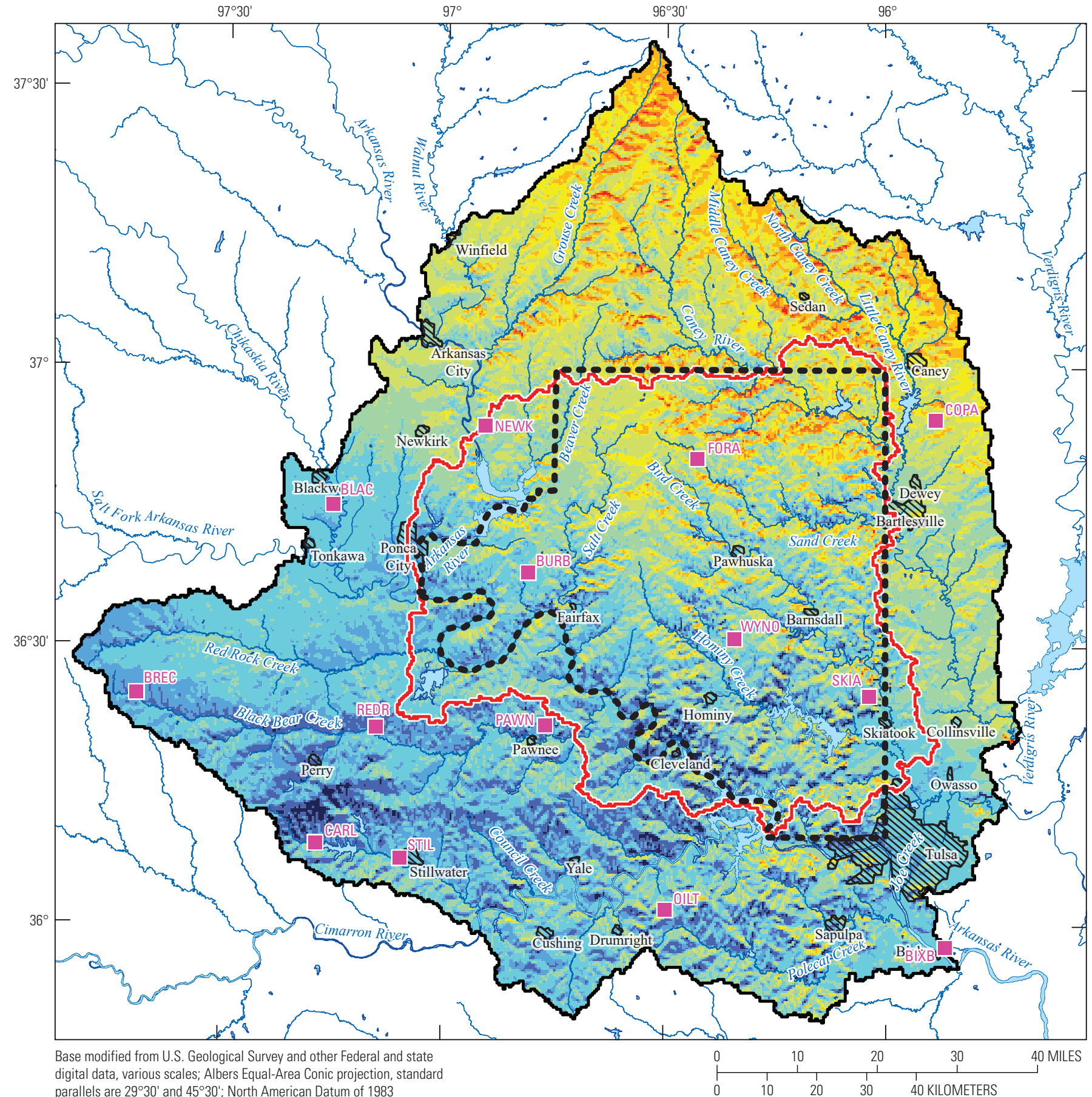

parallels are $29^{\circ} 30^{\prime}$ and $45^{\circ} 30^{\prime}$; North American Datum of 1983

EXPLANATION

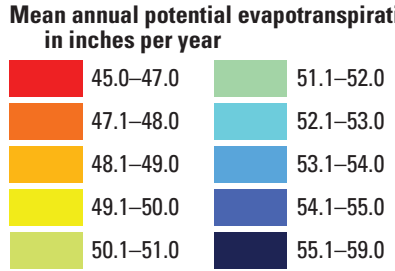

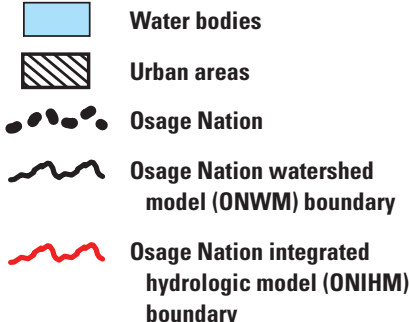

Major streams

OILT Oklahoma Climatological Survey

Mesonet station and identifier

(see tables 3 and 9)

Figure 27. Simulated mean annual potential evapotranspiration for water years 1915-2014 using the 0sage Nation watershed model, Oklahoma and Kansas. 

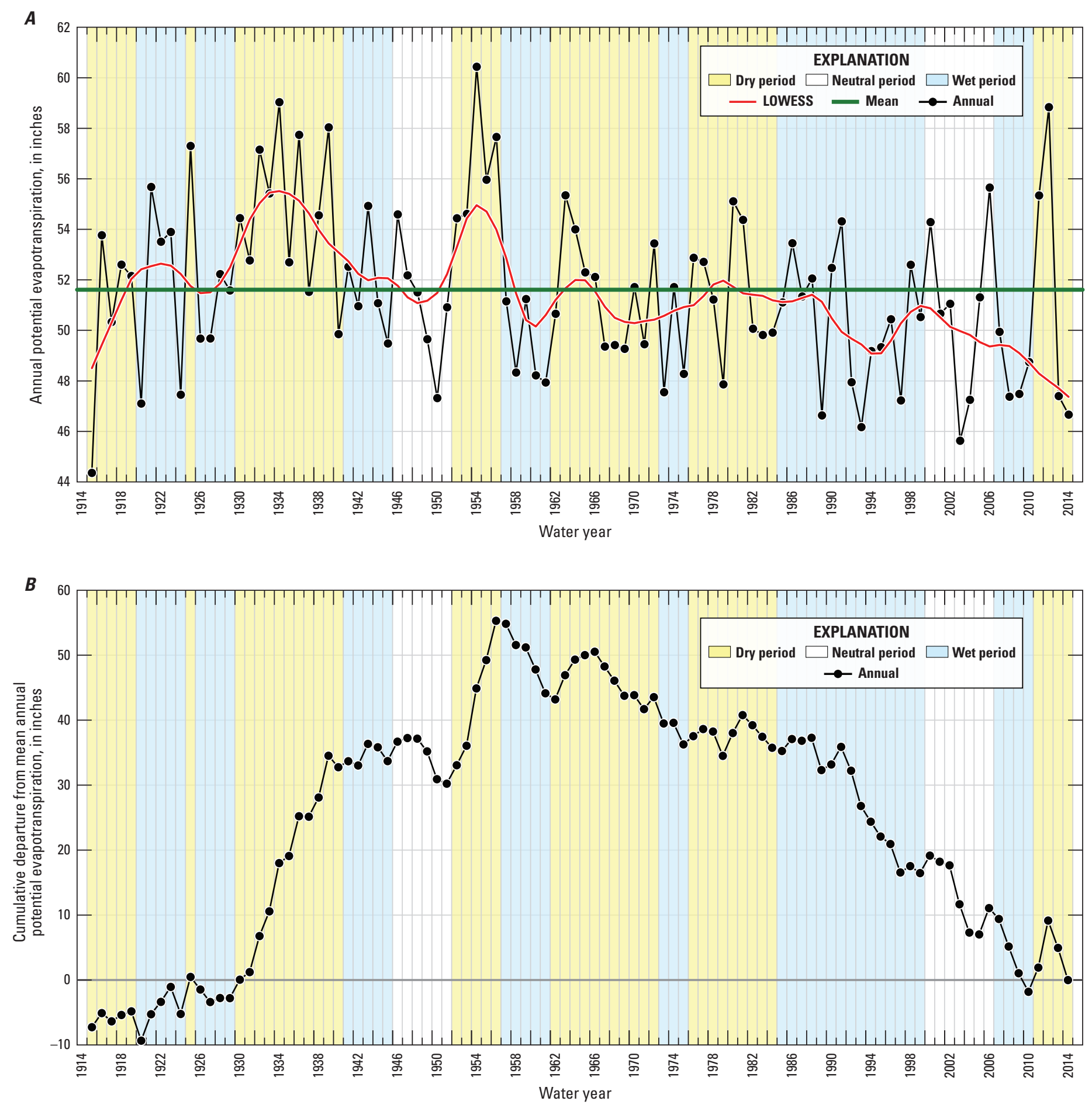

Figure 28. Simulated annual potential evapotranspiration for water years 1915-2014 using the 0sage Nation watershed model, Oklahoma and Kansas: $A$, total annual, and $B$, cumulative departure from the mean annual. 


\section{Stage-Three Calibration: Soil Moisture}

The third stage of calibration was done by comparing simulated to observed soil moisture at the 13 OCS Mesonet sites for which records of soil moisture were developed (table 10). For model calibration, simulated and observed soil moisture were expressed as the fractional soil-water content (volumetric fraction) of the root zone. Soil-moisture data available at the 13 OCS Mesonet stations (table 10; Oklahoma Climatological Survey, 2013) included the observed soil-water-content fraction relative to field capacity developed from continuous measurements at four depth intervals (Bradley and others, 2007). The observed soil moisture was calculated at each station as the weighted mean of the daily soil-water-content fraction recorded at the four depth intervals, with the weighting factors calculated using the interval thickness. The comparison to the observed soil moisture was done using the simulated soil-water-content fraction (soil-moisture) of the capillary reservoir component of the ONWM. Five PRMS parameters were adjusted during this calibration stage: (1) soil_moist_max, (2) sat_threshold, (3) soil_rechr_max, (4) transp_beg, and (5) transp_end (table 7). The soil_moist_max parameter defines the storage capacity of the capillary reservoir; the soil_rechr_max parameter defines the storage capacity of the upper capillary zone affected by bare soil evaporation; and the sat threshold parameter defines the macropore storage capacity of the soil zone in excess of the storage capacity defined by soil_moist_max. The transp_beg and transp_end parameters define the growing season as the beginning and ending months between which transpiration is simulated.

Results for Mesonet station WYNO provided an example of the goodness-of-fit comparison between the simulated and observed soil-moisture (fig. 29). The daily results for station WYNO indicated the observed soil-moisture ranged from a minimum of about 0.05 to a maximum of about 0.95 (fig. 29A). The simulated soil moisture indicated a similar range, with minimum values of about 0.1 and maximum values close to 1.0. The general fit between the simulated and observed daily soil moisture was considered to be good for station WYNO.

The monthly time-series results for simulated and observed soil moisture indicated a good fit to the seasonal variation in soil moisture, with maximum monthly mean simulated and observed values of about $0.9-0.95$ for the winter to early spring months (fig. 29B). The fit was good for the dry period during water years 2005 and 2006 and for the very dry daily and monthly soil-moisture conditions during the summers of water years 2000, 2001, and 2012. The annual mean results (fig. 29C) indicated a fair match to the general variations in mean water-year soil moisture, although the mean observed soil moisture for some years was underestimated somewhat, particularly for water years 2011 and 2013. The comparison between observed and simulated monthly mean soil moisture (fig. 29D) and mean monthly soil moisture (fig. 29E) indicated an overall underestimation of soil moisture of about 8 percent (table 10) for station WYNO.

Table 10. Goodness-of-fit results using simulated and observed soil-water-content fraction of the root zone, Osage Nation watershed model (ONWM), Oklahoma and Kansas.

[NSME, Nash-Sutcliffe model efficiency; PAEE, percent average estimation error; —, not applicable]

\begin{tabular}{|c|c|c|c|c|c|c|c|c|c|}
\hline \multirow{2}{*}{$\begin{array}{l}\text { Mesonet } \\
\text { climate } \\
\text { station }\end{array}$} & \multirow{2}{*}{$\begin{array}{c}\text { Number } \\
\text { of months } \\
\text { analyzed }\end{array}$} & \multicolumn{3}{|c|}{$\begin{array}{l}\text { Observed monthly average } \\
\text { soil-water-content fraction }\end{array}$} & \multicolumn{3}{|c|}{$\begin{array}{l}\text { Simulated monthly average } \\
\text { soil-water-content fraction }\end{array}$} & \multicolumn{2}{|c|}{$\begin{array}{l}\text { Goodness-of-fit } \\
\text { statistics }\end{array}$} \\
\hline & & Mean & Maximum & Minimum & Mean & Maximum & Minimum & PAEE & NSME \\
\hline BIXB & 192 & 0.80 & 0.97 & 0.19 & 0.77 & 1.00 & 0.18 & -3.3 & 0.54 \\
\hline BLAC & 189 & 0.67 & 0.96 & 0.18 & 0.67 & 0.99 & 0.12 & -0.2 & 0.83 \\
\hline BREC & 153 & 0.58 & 0.96 & 0.03 & 0.62 & 0.96 & 0.11 & 6.0 & 0.66 \\
\hline CARL & 70 & 0.61 & 0.95 & 0.09 & 0.60 & 0.96 & 0.14 & -0.5 & 0.87 \\
\hline FORA & 201 & 0.80 & 0.97 & 0.09 & 0.68 & 1.00 & 0.14 & -14.9 & 0.22 \\
\hline NEWK & 167 & 0.73 & 0.94 & 0.06 & 0.63 & 0.97 & 0.11 & -13.8 & 0.48 \\
\hline OILT & 171 & 0.75 & 0.95 & 0.19 & 0.66 & 0.98 & 0.15 & -11.7 & 0.26 \\
\hline PAWN & 201 & 0.72 & 0.97 & 0.05 & 0.64 & 0.96 & 0.09 & -11.1 & 0.73 \\
\hline REDR & 171 & 0.71 & 0.97 & 0.05 & 0.60 & 0.96 & 0.09 & -16.0 & 0.54 \\
\hline Weighted mean ${ }^{1}$ & - & 0.72 & 0.96 & 0.10 & 0.66 & 0.98 & 0.13 & 8.9 & 0.56 \\
\hline
\end{tabular}

${ }^{1}$ Weights were calculated for each station as the number of months analyzed divided by 2,179 , the total number of months analyzed for all stations. The weighted mean is the sum of the value for each station multiplied by the station weight for each station. The PAEE weighted mean is calculated using the absolute PAEE value for each station. 

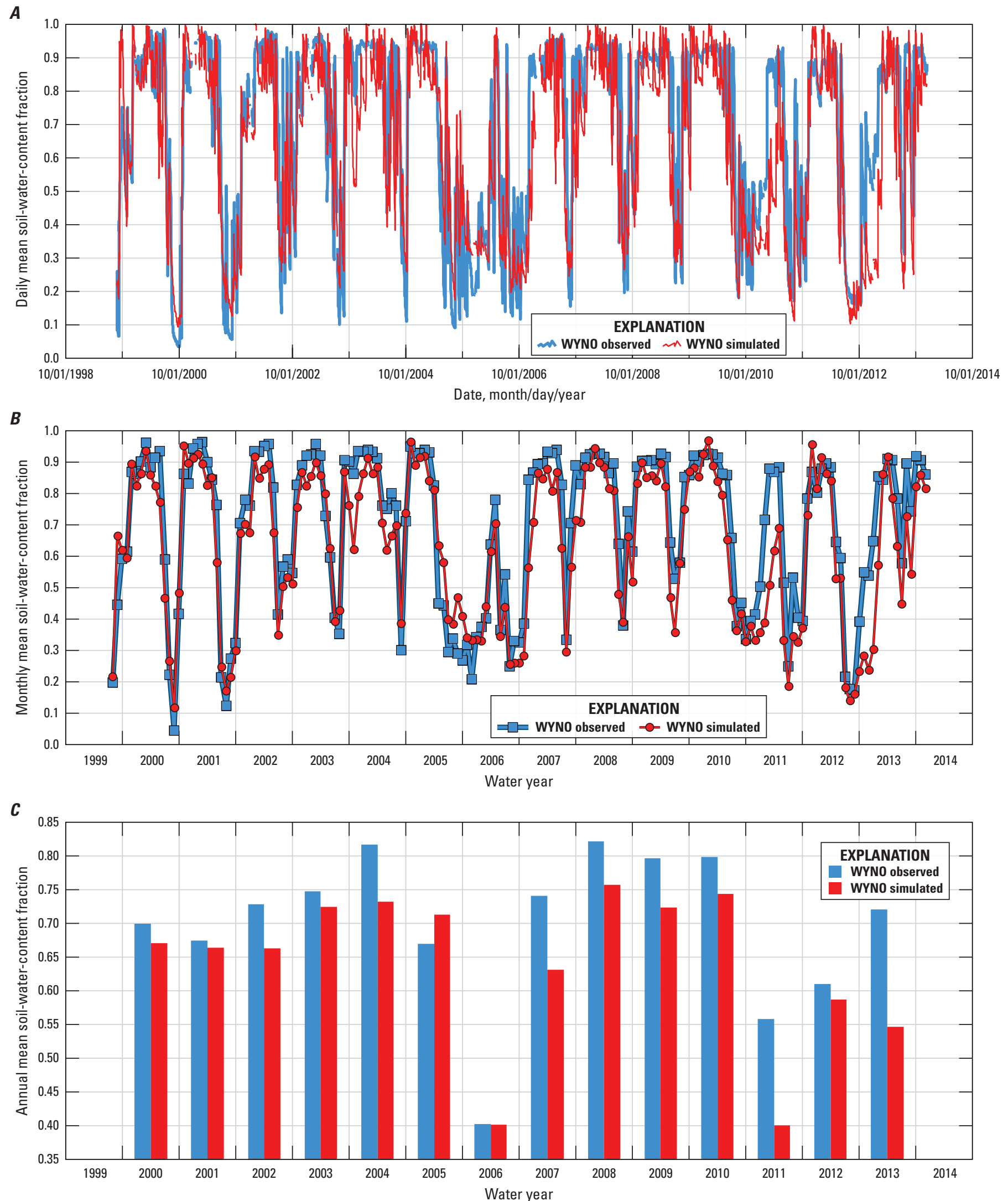

Figure 29. Comparison between simulated to observed soil-water-content fraction (soil moisture) at station WYNO using the Osage Nation watershed model, 0 klahoma and Kansas: $A$, daily mean time series; $B$, monthly mean time series; $C$, annual mean time series; $D$, monthly mean scatterplot; and $E$, mean monthly results. 

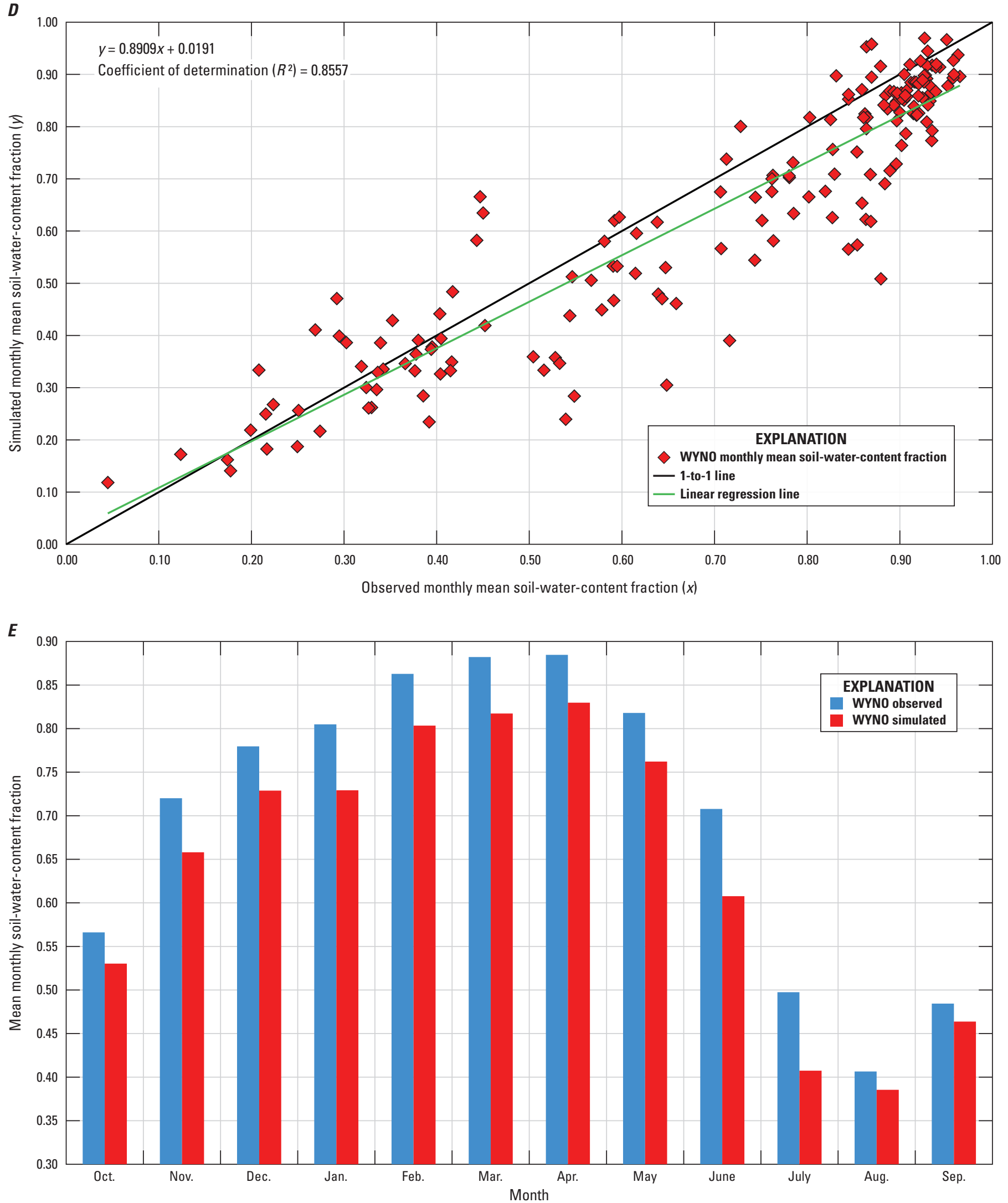

Figure 29. - Continued 
Goodness-of-fit statistics were calculated using monthly simulated and observed values for all 13 stations for which soil-moisture data were available (table 10). The goodnessof-fit statistics for station WYNO indicated a good calibration result for simulated soil moisture, with a PAEE value within plus or minus 10 percent and an NSME value of 0.8 . The PAEE results for the 13 stations indicated a tendency of the ONWM to underestimate soil moisture at most of the Mesonet sites, particularly stations FORA and REDR. The PAEE was within 10 percent for 7 of the 13 stations, however, and within 20 percent for all stations. The NSME statistic was greater than 0.5 for 8 of the 13 stations and greater than 0.7 for 5 stations. The NSME values were 0.8 or higher for stations BLAC, CARL, and WYNO. The overall calibration was considered satisfactory on the basis of the scatterplot of the mean monthly soil-water-content fraction for all stations, which indicated a reasonable fit around the 1-to-1 line (fig. 30A). The general match to the seasonal distribution of the mean monthly observed soil-water-content fraction for all stations was considered favorable, with the wettest soil conditions during February, March, and April and the driest soil conditions during July, August, and September (fig. 30B). A satisfactory overall fit was also indicated by the weighted mean PAEE result of -8.10 percent and NSME of 0.56 (table 10).

\section{Stage-Four Calibration: Streamflow}

The fourth and final stage of calibration consisted of adjusting model parameters affecting streamflow and evaluating the goodness-of-fit between simulated and observed streamflow. As with the stage-three calibration, parameters calibrated in stages 1 and 2 that were used for simulating SWRAD and PET were held fixed during stagefour calibration. The parameters calibrated in stage three for simulating soil moisture were not held fixed for the stage-four calibration, however. Instead, the calibration results for stage three were used only as a guide for stage-four calibration.

Stage-four calibration was considered the most important component of the overall calibration procedure. In contrast to the field observations representing point measurements at the OCS Mesonet stations, the streamflow records provided a measure of the integrated response of the larger scale hydrologic system for the drainage area upstream from the streamgage. The stage-four calibration process of fitting simulated streamflow to observed streamflow records included an analysis of model sensitivity to selected parameters using the Parameter Estimation program (PEST; Doherty, 2008).

Many parameters in PRMS affect the simulation of streamflow. As a test of model sensitivity to parameters identified as being critical to model calibration (because of a high degree of model sensitivity), a quantitative sensitivity analysis was performed using PEST and an initial set of estimated parameter values for 17 selected PRMS parameters: (1) carea_max, (2) fastcoef_lin, (3) fastcoef_sq, (4) gwflow_coef, (5) gwsink_coef, (6) pref_flow_den, (7) sat_threshold, (8) slowcoef_lin, (9) slowcoef_sq, (10) smidx_coef, (11) smidx_exp, (12) snowinfil_max, (13) soil_moist_max, (14) soil2gw_max, (15) srain_intcp, (16) ssr2gw_exp, and (17) ssr2gw_rate (table 7; fig. 31). Initial values for sat_threshold and soil_moist_max were based on the stage-three calibration results. The sensitivity analysis was done using the goodness-of-fit between simulated and observed monthly streamflow and records from nine USGS streamgages: CANE, CANH, CANR, BIRA, HOMS, BIRS, BLAP, COUS, and POLH (table 2).

The sensitivity analysis helped identify parameters critical for model calibration, as well as parameters having little effect on calibration results for streamflow (Hill, 1998). The PEST application was not used for automated parameter estimation and calibration; all model calibration was done using manual trial-and-error fitting. The results from the PEST sensitivity analysis were used only as an initial guide for identifying the most critical parameters to adjust during trialand-error calibration.

Stage-four trial-and-error model calibration was done qualitatively and quantitatively and consisted of comparing simulated to observed streamflow at 22 USGS streamgages within the ONWM area (fig. 21; table 2). The goodness-of-fit between simulated and observed streamflow was evaluated using daily mean streamflow, monthly mean streamflow, annual (water year) mean streamflow, and mean monthly streamflow. The qualitative analysis also included scatterplots of simulated against observed monthly and annual streamflow to evaluate residuals. The qualitative analysis consisted of a visual assessment of the fit of the scatterplot of simulated against observed values to the 1-to-1 line indicating a perfect fit, in conjunction with the $R^{2}$ value from linear regression of the scatterplot dataset. The comparison of simulated and mean monthly streamflow was done to evaluate model performance in terms of the seasonal distribution of streamflow. 
$\boldsymbol{A}$

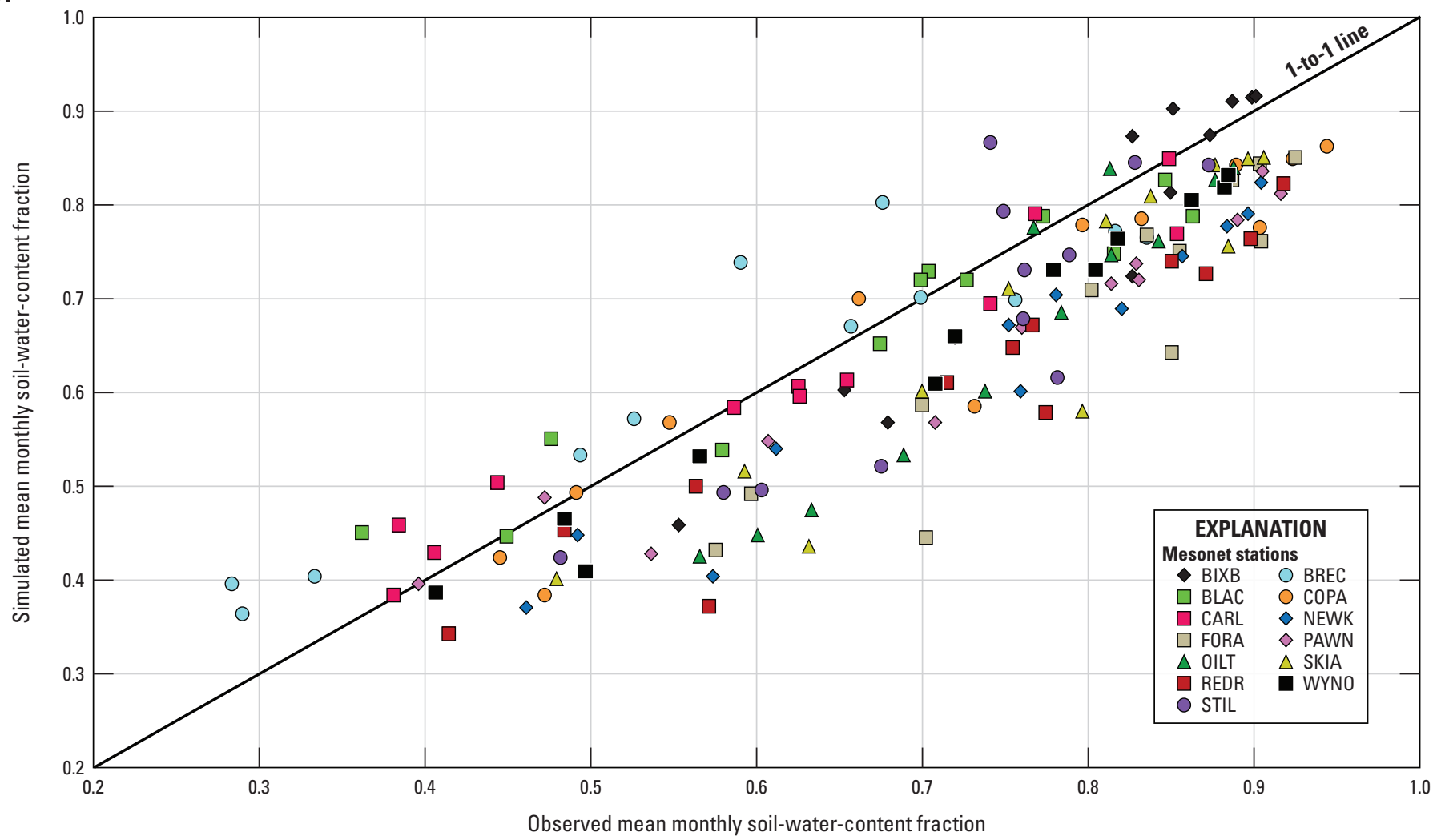

B

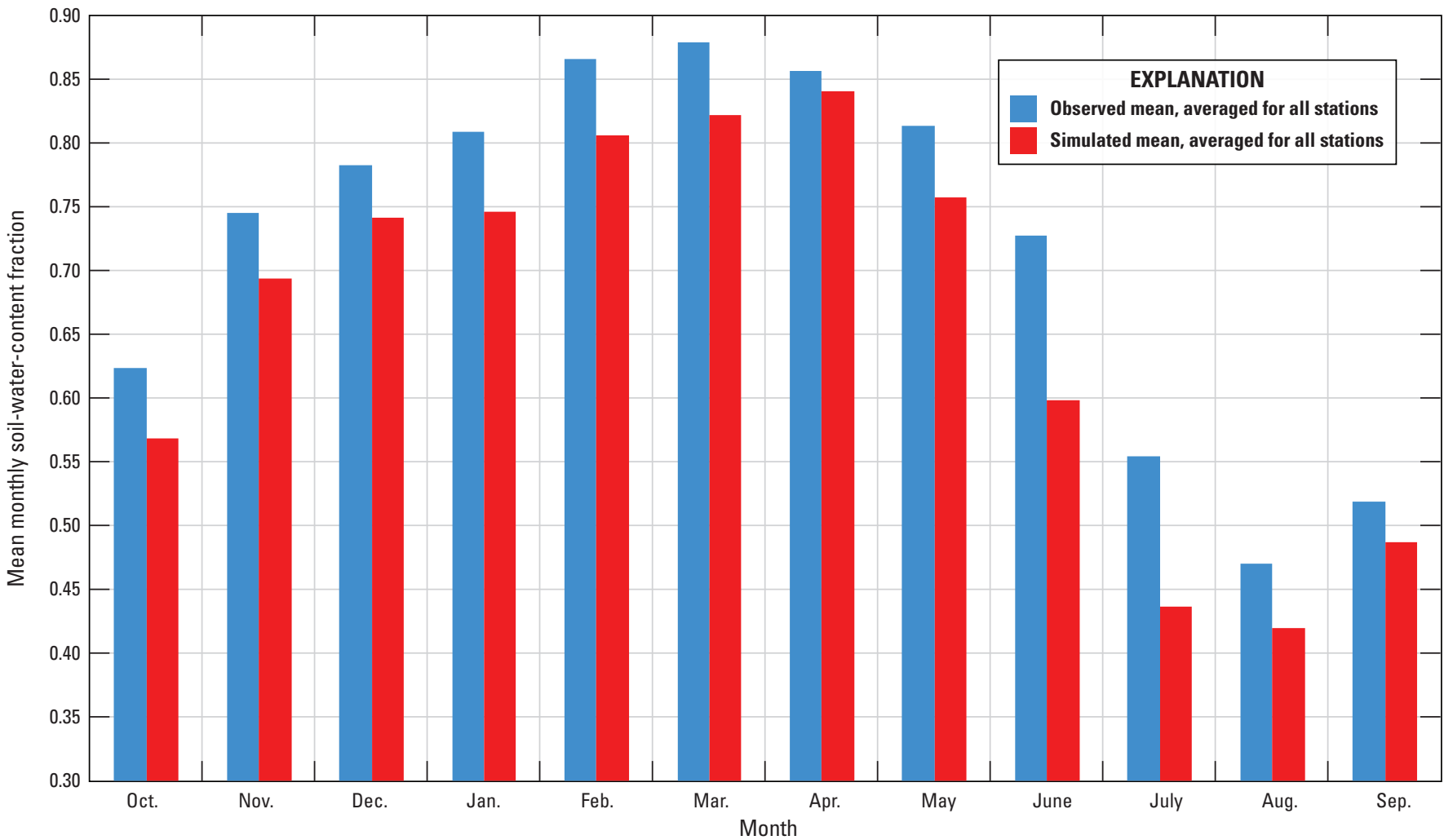

Figure 30. Comparison of simulated to observed soil-water-content fraction at 13 Oklahoma Climatological Survey Mesonet stations, the Osage Nation Watershed Model, Oklahoma and Kansas: $A$, scatterplot of mean monthly values for all stations, and $B$, mean monthly results, averaged for all stations. 

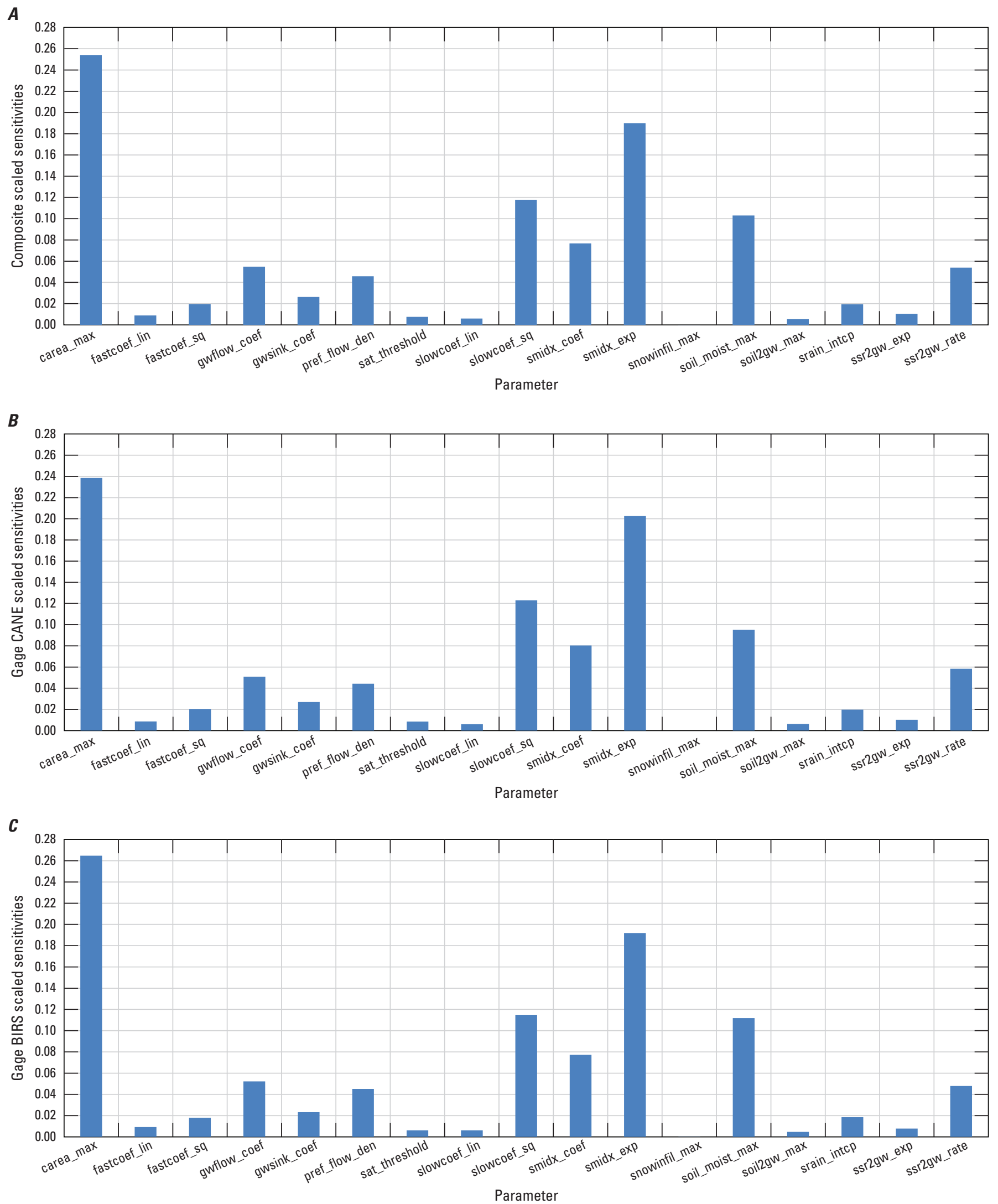

Figure 31. Sensitivity results for streamflow using the Osage Nation Watershed Model, Oklahoma and Kansas: A, composite scaled sensitivity; $B$, scaled sensitivity for streamgage CANE (U.S. Geological Survey streamgage 07172000 Caney River near Elgin, KS); and C, scaled sensitivity for streamgage BIRS (U.S. Geological Survey streamgage 07177500 Bird Creek near Sperry, OK). 


\section{Model Sensitivity using Simulated Streamflow}

Results from the PEST sensitivity analysis included analysis of composite scaled sensitivities for selected parameters using all observations as well as scaled sensitivities for selected observations (Hill, 1998). The results indicated high sensitivity to the parameter carea_max, with the highest composite scaled sensitivity at about 0.25 (fig. $31 \mathrm{~A}$ ), as well as the highest scaled sensitivity, 0.24 and 0.26 , at streamgages CANE and BIRS, respectively (figs. $31 B$, $C)$. Scaled sensitivities were also high for the parameters smidx_exp and smidx_coef. These three parameters control the rate of Hortonian runoff generation and are estimated for the ONWM using land-surface slope and soil properties. The third highest scaled sensitivity for the composite result as well as for the individual streamgages was about 0.12 for parameter slowcoefsq, which controls the rate of interflow (Markstrom and others, 2015). Model sensitivity was also comparatively high (greater than 0.04) for the parameters soil_moist_max, ssr2gw_rate, gwflow_coef, and pref_flow_den. The parameter soil_moist_max defines the root-zone capillary-storage component and affects simulated ET and the generation of saturation-excess (Dunnian) runoff. The parameter $s s r 2 g w$ rate controls the recharge rate from the soil zone to the groundwater reservoir, and gwflow_coef controls the rate of groundwater discharge to downstream groundwater reservoirs in cascading flow paths and to stream segments. The pref_flow_den parameter controls the magnitude of fast interflow.

The PEST analysis indicated no to very low model sensitivity to parameter snowinfil_max and comparatively low sensitivity to the parameters fastcoef_lin, sat_threshold, slowcoef_lin, soil2gw_max, and ssr2gw_exp. Parameter snowinfil_max affects the rate of infiltration of snowmelt to the soil zone, and results indicated low sensitivity because of the infrequent snowfall in the ONWM area. The parameters fastcoef_lin and sat_threshold affect the simulation of the preferential-flow (fast-interflow) rate, whereas slowcoef_lin affects the slow-interflow rate from the gravity reservoir. The parameters soil2gw_max and ssr2gw_exp affect the recharge rate. It is important to note that many of the parameters used in PRMS are interdependent, and the value of one parameter can affect model sensitivity to the value of another dependent parameter. Examples of interdependent parameters are carea_max,smidx_coef, and smidx_exp; and pref_flow_den, fastcoef_lin, and fastcoef_sq.

The following subsections present calibration results for streamflow at four selected streamgages to illustrate not only the variability among streamgages but also some common patterns in the results.

\section{Calibration Results at Streamgage BIR0}

The comparison between simulated and observed streamflow at streamgage BIRO (USGS 07178000 Bird Creek near Owasso, OK) indicated a good general fit to the timing and magnitude of the maximum daily mean streamflows for water years 1987-2014 (figs. 32A, B). The simulated maximum daily streamflow of about $21,520 \mathrm{ft}^{3} / \mathrm{s}$ provided a satisfactory match to the observed maximum daily mean streamflow of 27,700 ft³ on May 11, 1993. Simulated streamflow indicated a satisfactory general match to the maximum daily mean streamflow of more than $18,000 \mathrm{ft}^{3} / \mathrm{s}$ observed during water years 2006-09 (fig. 32B). The fit of simulated to observed low flows for water years 2006-09 was considered satisfactory (fig. 32C), given that this streamgage is on the lower section of Bird Creek and is subject to flow regulation from Bluestem Lake, Birch Lake, and Skiatook Lake. The Muskingum flow routing improved the calibration results for daily streamflow at BIRO, resulting in an acceptable NSME of 0.55 and a good PAEE of -0.4 percent (table $11 A$ ).

Comparison of simulated to observed monthly streamflow at streamgage BIRO indicated a good match (fig. 33A), with a good fit to the maximum and minimum monthly flows. Comparison of simulated to observed annual (water year) streamflow indicated a good general fit to the year-to-year variations in annual streamflow (fig. 33B). The PAEE results of -0.4 percent for monthly flows and 0.3 percent for annual flows indicated little to no estimation bias for streamgage BIRO, and the NSME results of 0.76 and 0.86 for monthly and annual streamflow, respectively, indicated a good overall calibration for streamgage BIRO (table 11).

\section{Calibration Results at Streamgage BLAP}

The comparison between simulated and observed streamflow at streamgage BLAP (USGS 07153000 Black Bear Creek at Pawnee, OK) also indicated a good general fit to the timing and magnitude of the maximum daily mean flows for water years 1945-2014 (figs. 34A, B). The simulated maximum daily mean streamflow of $18,500 \mathrm{ft}^{3} / \mathrm{s}$ was a satisfactory match to the maximum daily mean flow of 25,400 ft $3 / \mathrm{s}$ observed on October 3, 1959 (fig. 34A; table 11A). Simulated streamflow indicated a good general match to high and low values of daily mean flow observed for water years 1985-88 (figs. 34B, C). The PAEE result of 2.4 percent for daily, monthly, and annual streamflow indicated small estimation bias. The NSME result of 0.75 indicated a good overall match to daily mean streamflow at streamgage BLAP. Although there was no flow regulation upstream from the streamgage, the Muskingum routing improved the fit of simulated daily flow to observed daily flow because the lag time was more than 24 hours for streamflow generated in the headwaters of the upstream drainage area to reach the streamgage. 

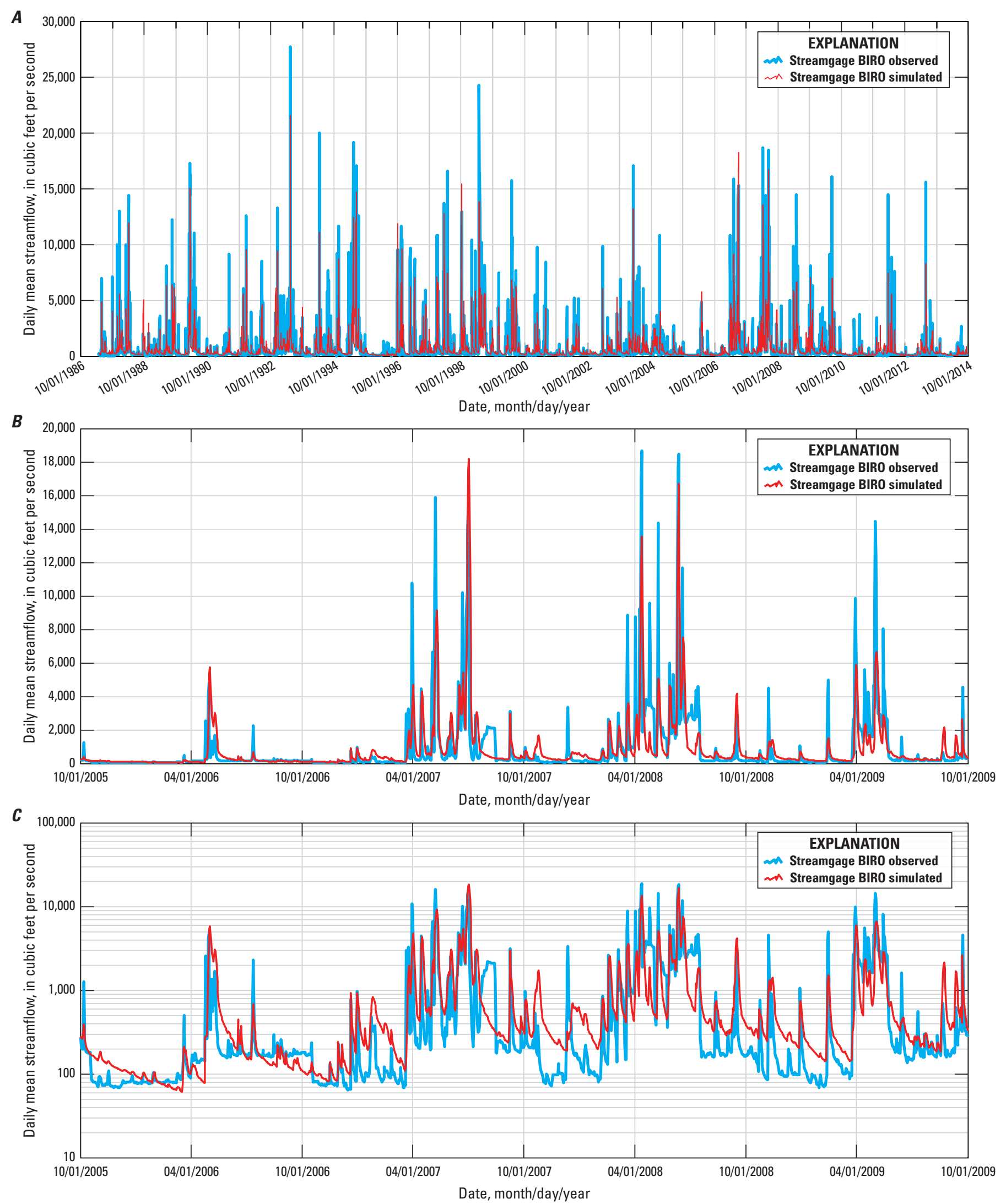

Figure 32. Comparison between simulated streamflow using the Osage Nation watershed model and observed streamflow at streamgage BIRO (U.S. Geological Survey streamgage 07178000 Bird Creek near Owasso, OK), Oklahoma and Kansas: A, daily mean streamflow for water years 1987-2014; $B$, daily mean streamflow for water years 2006-09; and $C$, daily mean streamflow for water years 2006-09, logarithmic scale. 
Table 11A. Goodness-of-fit results using simulated and observed daily mean streamflow, Osage Nation watershed model (ONWM), Oklahoma and Kansas.

[fts/s, cubic feet per second; ID, identification; USGS, U.S. Geological Survey; - , not applicable]

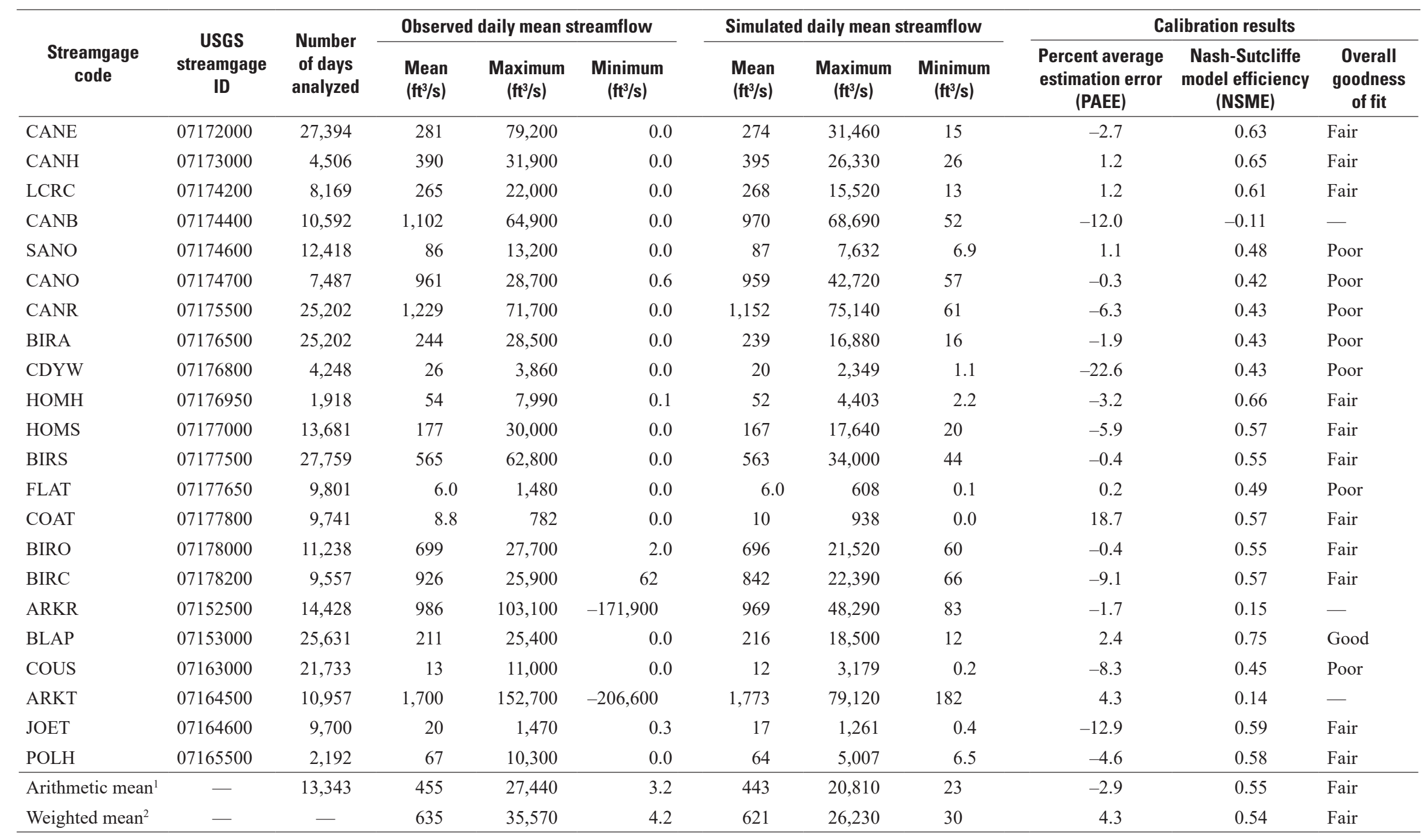

${ }^{1}$ Calculation of arithmetic means for maximum and minimum streamflows does not include results for ARKR and ARKT. Calculation of arithmetic means for the NSME does not include results for CANB, ARKR, and ARKT.

${ }^{2}$ Weights were calculated for each streamgage as the average of two products consisting of (1) the number of days analyzed at each streamgage divided by 293,554 , the total number of days analyzed for all streamgages and (2) the square root of the total contributing drainage area for each streamgage divided by the sum of the square root of the total drainage area for all streamgages. The weighted mean is the sum of the value for each station multiplied by the station weight for each station. The PAEE weighted mean is calculated using the absolute PAEE value for each station. The weighted means for maximum and minimum values excludes results for ARKR and ARKT. The weighted mean for NSME excludes results for ARKR, ARKT, and CANB. 
Table 11B. Goodness-of-fit results using observed and simulated monthly mean discharge, Osage Nation watershed model (ONWM), Oklahoma and Kansas.

[ft³/s, cubic feet per second; ID, identification; USGS, U.S. Geological Survey; - , not applicable]

\begin{tabular}{|c|c|c|c|c|c|c|c|c|c|c|c|}
\hline \multirow[b]{2}{*}{$\begin{array}{c}\text { Streamgage } \\
\text { code }\end{array}$} & \multirow[b]{2}{*}{$\begin{array}{c}\text { USGS } \\
\text { streamgage } \\
\text { ID }\end{array}$} & \multirow[b]{2}{*}{$\begin{array}{l}\text { Number } \\
\text { of months } \\
\text { analyzed }\end{array}$} & \multicolumn{3}{|c|}{ Observed monthly mean streamflow } & \multicolumn{3}{|c|}{ Simulated monthly mean streamflow } & \multicolumn{3}{|c|}{ Calibration results } \\
\hline & & & $\begin{array}{l}\text { Mean } \\
\left(\mathrm{ft}^{3} / \mathrm{s}\right)\end{array}$ & $\begin{array}{c}\text { Maximum } \\
\left(\mathrm{ft}^{3} / \mathbf{s}\right)\end{array}$ & $\begin{array}{c}\text { Minimum } \\
\left(\mathrm{ft}^{3} / \mathrm{s}\right)\end{array}$ & $\begin{array}{r}\text { Mean } \\
\left(\mathrm{ft}^{3} / \mathrm{s}\right)\end{array}$ & $\begin{array}{c}\text { Maximum } \\
\quad\left(\mathrm{ft}^{3} / \mathrm{s}\right)\end{array}$ & $\begin{array}{c}\text { Minimum } \\
\left(\mathrm{ft}^{3} / \mathbf{s}\right)\end{array}$ & $\begin{array}{c}\text { Percent average } \\
\text { estimation error } \\
\text { (PAEE) }\end{array}$ & $\begin{array}{l}\text { Nash-Sutcliffe } \\
\text { model efficiency } \\
\text { (NSME) }\end{array}$ & $\begin{array}{c}\text { Overall } \\
\text { goodness } \\
\text { of fit }\end{array}$ \\
\hline CANE & 07172000 & 900 & 282 & 5,567 & 0.0 & 274 & 4,117 & 16 & -2.8 & 0.83 & Good \\
\hline CANH & 07173000 & 161 & 402 & 3,977 & 0.0 & 401 & 4,136 & 28 & -0.1 & 0.84 & Fair \\
\hline LCRC & 07174200 & 269 & 265 & 4,045 & 0.0 & 268 & 3,223 & 15 & 1.1 & 0.75 & Good \\
\hline CANB & 07174400 & 348 & 1,100 & 14,800 & 2.8 & 969 & 13,790 & 59 & -11.9 & 0.74 & Fair \\
\hline SANO & 07174600 & 408 & 86 & 1,010 & 0.0 & 87 & 981 & 7.8 & 1.0 & 0.73 & Fair \\
\hline CANO & 07174700 & 246 & 960 & 9,885 & 1.6 & 958 & 9,519 & 65 & -0.3 & 0.83 & Good \\
\hline CANR & 07175500 & 828 & 1,228 & 19,540 & 0.0 & 1,151 & 18,670 & 70 & -6.3 & 0.81 & Good \\
\hline BIRA & 07176500 & 828 & 244 & 2,648 & 0.0 & 239 & 2,779 & 20 & -1.9 & 0.79 & Good \\
\hline CDYW & 07176800 & 140 & 26 & 195 & 0.0 & 20 & 133 & 1.3 & -22.8 & 0.70 & Poor \\
\hline HOMH & 07176950 & 63 & 54.0 & 533 & 0.3 & 52 & 639 & 2.9 & -3.1 & 0.88 & Good \\
\hline HOMS & 07177000 & 450 & 177 & 2,318 & 0.0 & 166 & 2,344 & 25 & -5.9 & 0.80 & Good \\
\hline BIRS & 07177500 & 912 & 565 & 9,862 & 0.0 & 563 & 6,974 & 54 & -0.4 & 0.80 & Good \\
\hline FLAT & 07177650 & 322 & 6.0 & 59 & 0.0 & 6.0 & 38 & 0.1 & 0.3 & 0.69 & Fair \\
\hline COAT & 07177800 & 320 & 8.8 & 46 & 0.3 & 10 & 51 & 0.0 & 18.7 & 0.56 & Poor \\
\hline BIRO & 07178000 & 369 & 699 & 5,861 & 3.2 & 697 & 5,134 & 71 & -0.4 & 0.76 & Good \\
\hline BIRC & 07178200 & 314 & 926 & 6,393 & 106 & 842 & 5,639 & 82 & -9.1 & 0.77 & Good \\
\hline ARKR & 07152500 & 474 & 983 & 12,630 & $-3,656$ & 967 & 13,940 & 94 & -1.6 & 0.70 & Fair \\
\hline BLAP & 07153000 & 842 & 210 & 4,025 & 0.0 & 215 & 3,868 & 14 & 2.4 & 0.86 & Excellent \\
\hline COUS & 07163000 & 714 & 13 & 429 & 0.0 & 12 & 239 & 0.3 & -8.3 & 0.74 & Fair \\
\hline ARKT & 07164500 & 360 & 1,694 & 23,240 & $-4,466$ & 1,767 & 29,640 & 209 & 4.4 & 0.75 & Good \\
\hline JOET & 07164600 & 319 & 20 & 107 & 1.0 & 17 & 72 & 0.6 & -12.9 & 0.71 & Fair \\
\hline POLH & 07165500 & 432 & 52 & 678 & 0.0 & 50 & 561 & 4.8 & -4.2 & 0.76 & Good \\
\hline Arithmetic mean $^{1}$ & - & 455 & 455 & 4,599 & 5.8 & 442 & 4,145 & 27 & -2.9 & 0.76 & Good \\
\hline Weighted mean ${ }^{2}$ & - & - & 626 & 6,580 & 6.7 & 612 & 5,912 & 36 & 4.3 & 0.77 & Good \\
\hline
\end{tabular}

${ }^{1}$ Calculation of arithmetic means for maximum and minimum values does not include results for ARKR and ARKT.

${ }^{2}$ Weights were calculated for each streamgage as the average of two products consisting of (1) the number of months analyzed at each streamgage divided by 10,017 , the total number of months analyzed for all streamgages and (2) the square root of the total contributing drainage area for each streamgage divided by the sum of the square root of the total drainage area for all streamgages. The weighted mean is the sum of the value for each station multiplied by the station weight for each station. The PAEE weighted mean is calculated using the absolute PAEE value for each station. The weighted means for maximum and minimum values excludes results for ARKR and ARKT. 
Table 11C. Goodness-of-fit results using simulated and observed annual mean discharge, Osage Nation watershed model (ONWM), Oklahoma and Kansas.

[fts/s, cubic feet per second; ID, identification; USGS, U.S. Geological Survey; -, not applicable]

\begin{tabular}{|c|c|c|c|c|c|c|c|c|c|c|c|}
\hline \multirow[b]{2}{*}{$\begin{array}{l}\text { Streamgage } \\
\text { code }\end{array}$} & \multirow[b]{2}{*}{$\begin{array}{c}\text { USGS } \\
\text { streamgage } \\
\text { ID }\end{array}$} & \multirow[b]{2}{*}{$\begin{array}{l}\text { Number } \\
\text { of years } \\
\text { analyzed }\end{array}$} & \multicolumn{3}{|c|}{ Observed annual mean streamflow } & \multicolumn{3}{|c|}{ Simulated annual mean streamflow } & \multicolumn{3}{|c|}{ Calibration results } \\
\hline & & & $\begin{array}{l}\text { Mean } \\
\left(\mathrm{ft}^{3} / \mathrm{s}\right)\end{array}$ & $\begin{array}{l}\text { Maximum } \\
\left(\mathrm{ft}^{3} / \mathrm{s}\right)\end{array}$ & $\begin{array}{c}\text { Minimum } \\
\left(\mathrm{ft}^{3} / \mathrm{s}\right)\end{array}$ & $\begin{array}{l}\text { Mean } \\
\left(\mathrm{ft}^{3} / \mathrm{s}\right)\end{array}$ & $\begin{array}{l}\text { Maximum } \\
\qquad\left(\mathrm{ft}^{3} / \mathrm{s}\right)\end{array}$ & $\begin{array}{c}\text { Minimum } \\
\left(\mathrm{ft}^{3} / \mathbf{s}\right)\end{array}$ & $\begin{array}{l}\text { Percent average } \\
\text { estimation error } \\
\text { (PAEE) }\end{array}$ & $\begin{array}{l}\text { Nash-Sutcliffe } \\
\text { model efficiency } \\
\text { (NSME) }\end{array}$ & $\begin{array}{c}\text { Overall } \\
\text { goodness } \\
\text { of fit }\end{array}$ \\
\hline CANE & 07172000 & 75 & 281 & 891 & 8.6 & 274 & 710 & 45 & -2.7 & 0.88 & Excellent \\
\hline CANH & 07173000 & 13 & 413 & 824 & 39 & 412 & 759 & 104 & -3.0 & 0.92 & Excellent \\
\hline LCRC & 07174200 & 23 & 258 & 658 & 2.3 & 262 & 819 & 27 & 1.4 & 0.81 & Good \\
\hline CANB & 07174400 & 29 & 1,102 & 2,888 & 44 & 970 & 2,130 & 191 & -12.0 & 0.84 & Fair \\
\hline SANO & 07174600 & 34 & 86 & 221 & 5.5 & 87 & 193 & 18 & 1.1 & 0.90 & Excellent \\
\hline CANO & 07174700 & 21 & 939 & 2,237 & 12 & 939 & 2,266 & 108 & 0.0 & 0.93 & Excellent \\
\hline CANR & 07175500 & 69 & 1,229 & 3,887 & 59 & 1,152 & 2,947 & 248 & -6.3 & 0.90 & Good \\
\hline BIRA & 07176500 & 69 & 244 & 673 & 5.5 & 239 & 564 & 53 & -1.9 & 0.88 & Excellent \\
\hline CDYW & 07176800 & 12 & 25 & 59 & 6.2 & 19 & 47 & 3.6 & -22.8 & 0.78 & Poor \\
\hline HOMH & 07176950 & 5 & 56 & 102 & 12 & 53 & 114 & 15 & -5.0 & 0.87 & Good \\
\hline HOMS & 07177000 & 38 & 177 & 609 & 6.4 & 167 & 430 & 47 & -5.8 & 0.87 & Good \\
\hline BIRS & 07177500 & 76 & 565 & 1,669 & 15 & 563 & 1,350 & 121 & -0.4 & 0.89 & Excellent \\
\hline FLAT & 07177650 & 27 & 6.0 & 15 & 0.5 & 6.0 & 13 & 1.1 & -0.1 & 0.82 & Fair \\
\hline COAT & 07177800 & 27 & 8.8 & 17 & 3.6 & 10 & 19 & 4.1 & 18.5 & 0.46 & Poor \\
\hline BIRO & 07178000 & 32 & 681 & 1,906 & 26 & 683 & 1,538 & 126 & 0.3 & 0.86 & Excellent \\
\hline $\mathrm{BIRC}$ & 07178200 & 26 & 930 & 2,127 & 258 & 842 & 1,740 & 239 & -9.4 & 0.85 & Good \\
\hline ARKR & 07152500 & 40 & 976 & 2,733 & 120 & 960 & 2,385 & 242 & -1.7 & 0.83 & Good \\
\hline BLAP & 07153000 & 70 & 211 & 835 & 13 & 216 & 681 & 34 & 2.4 & 0.93 & Excellent \\
\hline COUS & 07163000 & 60 & 13 & 54 & 0.7 & 12 & 43 & 0.9 & -7.7 & 0.75 & Fair \\
\hline ARKT & 07164500 & 30 & 1,700 & 4,688 & 199 & 1,773 & 4,614 & 527 & 4.3 & 0.84 & Good \\
\hline JOET & 07164600 & 27 & 19 & 35 & 7.1 & 17 & 31 & 7.9 & -12.9 & 0.67 & Fair \\
\hline POLH & 07165500 & 36 & 52 & 143 & 1.8 & 50 & 132 & 9.0 & -4.1 & 0.93 & Excellent \\
\hline Arithmetic mean & - & 38 & 453 & 1,240 & 38 & 441 & 1,069 & 99 & -3.0 & 0.84 & Good \\
\hline Weighted mean ${ }^{1}$ & - & - & 625 & 1,744 & 52 & 611 & 1,502 & 140 & 4.3 & 0.86 & Excellent \\
\hline
\end{tabular}

${ }^{1}$ Weights were calculated for each streamgage as the average of two products consisting of (1) the number of years analyzed at each streamgage divided by 839 , the total number of years analyzed for all streamgages and (2) the square root of the total contributing drainage area for each streamgage divided by the sum of the square root of the total drainage area for all streamgages. The weighted mean is the sum of the value for each station multiplied by the station weight for each station. The PAEE weighted mean is calculated using the absolute PAEE value for each station. 

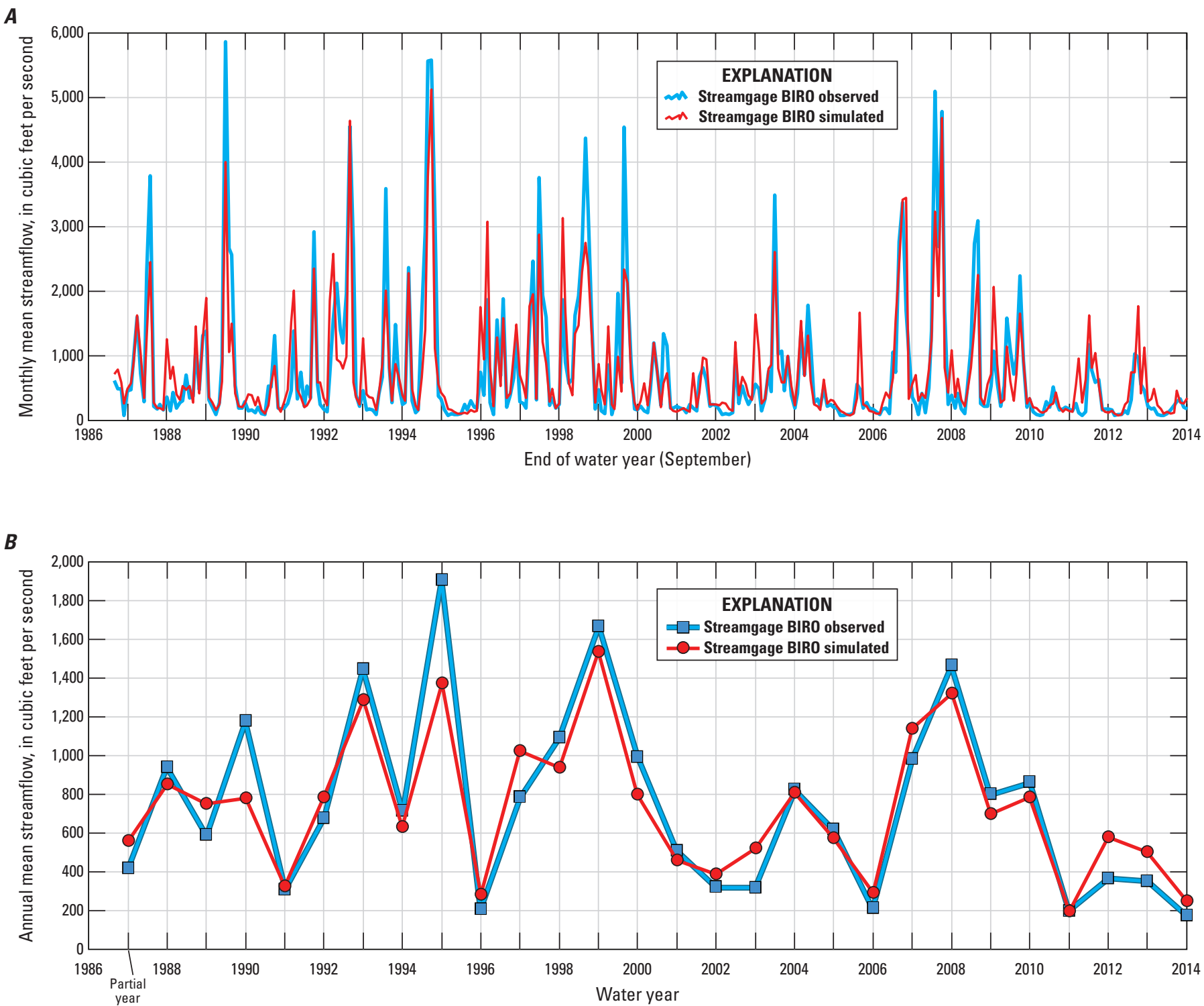

Figure 33. Comparison between simulated streamflow using the Osage Nation watershed model and observed streamflow at streamgage BIRO (U.S. Geological Survey streamgage 07178000 Bird Creek near Owasso, 0K), Oklahoma and Kansas: $A$, monthly mean streamflow for water years 1987 to 2014, and B, annual mean streamflow for water years 1987 to 2014.

Comparison between simulated and observed monthly mean streamflow at streamgage BLAP indicated an excellent match (fig. 35A). As with the results for streamgage BIRO, the simulated flows at streamgage BLAP provided a good fit to the observed maximum and minimum monthly mean flows. Comparison between simulated and observed annual mean streamflow also indicated an excellent fit to the year-to-year variations in streamflow (fig. 35B). The NSME results of 0.86 and 0.93 for monthly and annual mean flows, respectively, combined with a PAEE result of less than 3 percent and an NSME of 0.75 for daily mean streamflow, indicated an excellent overall calibration result for streamgage BLAP (table 11). 
$\boldsymbol{A}$

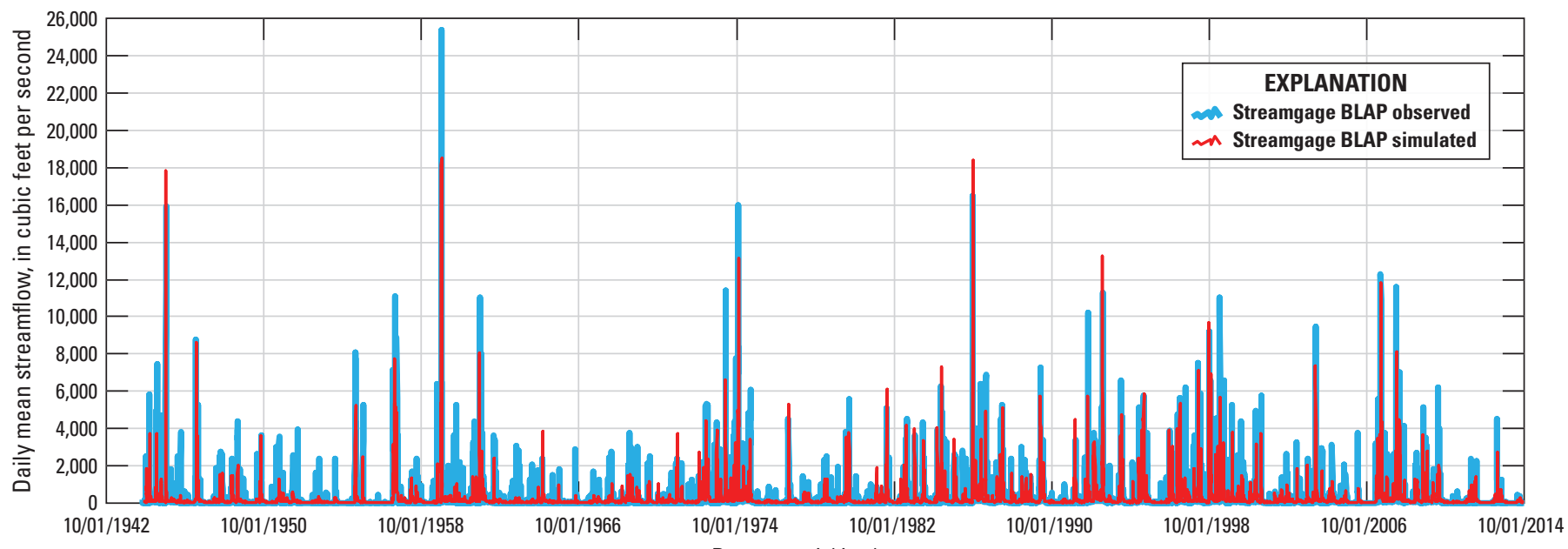

Date, month/day/year
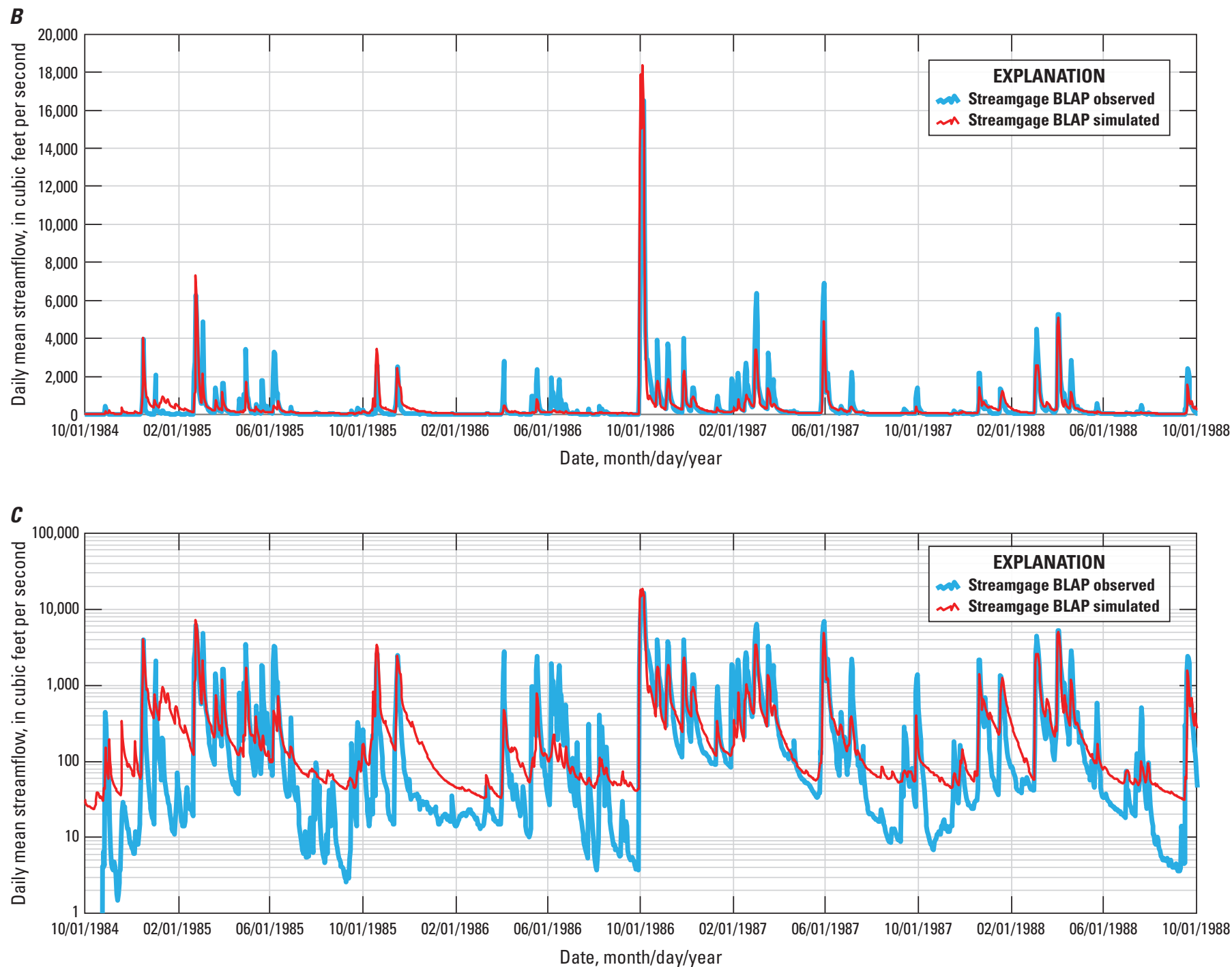

Figure 34. Comparison between simulated streamflow using the 0 sage Nation watershed model and observed streamflow at streamgage BLAP (U.S. Geological Survey streamgage 07153000 Black Bear Creek at Pawnee, OK), Oklahoma and Kansas: $A$, daily mean streamflow for period of calibration; $B$, daily mean streamflow for water years 1985-88; and $C$, daily mean streamflow for water years 1985-88, logarithmic scale. 


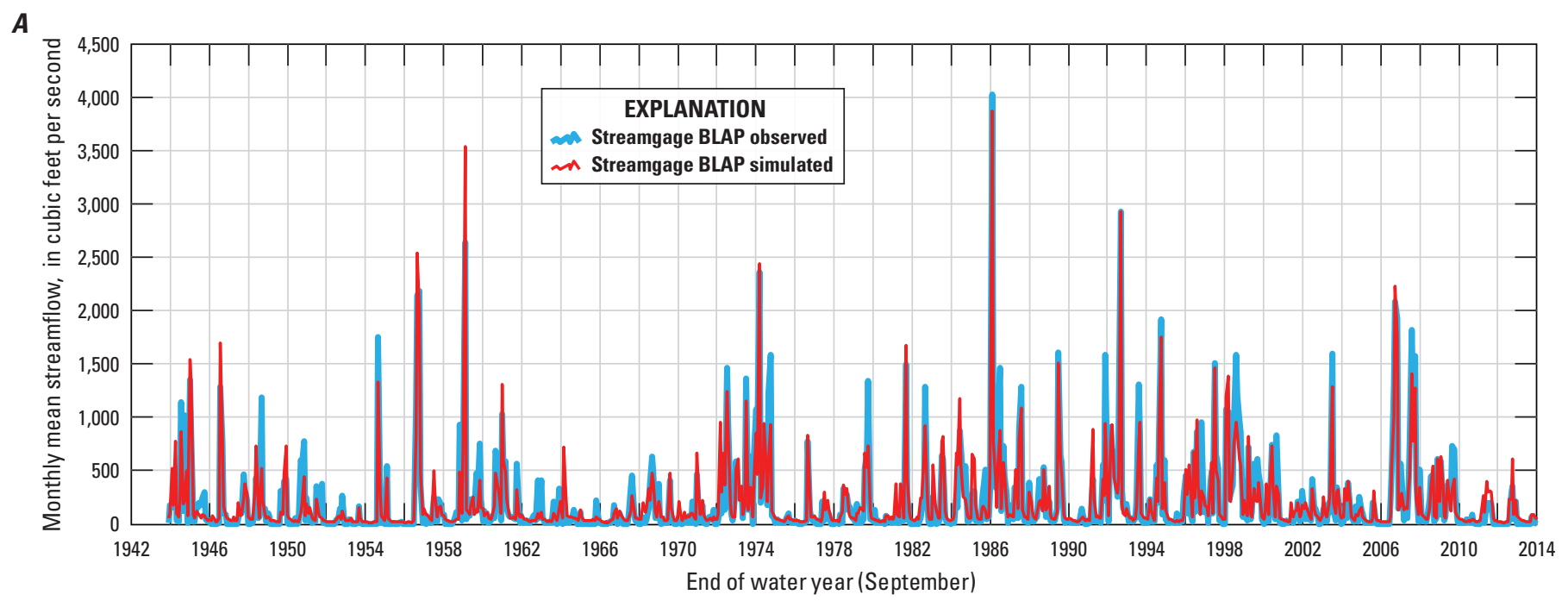

$\boldsymbol{B}$

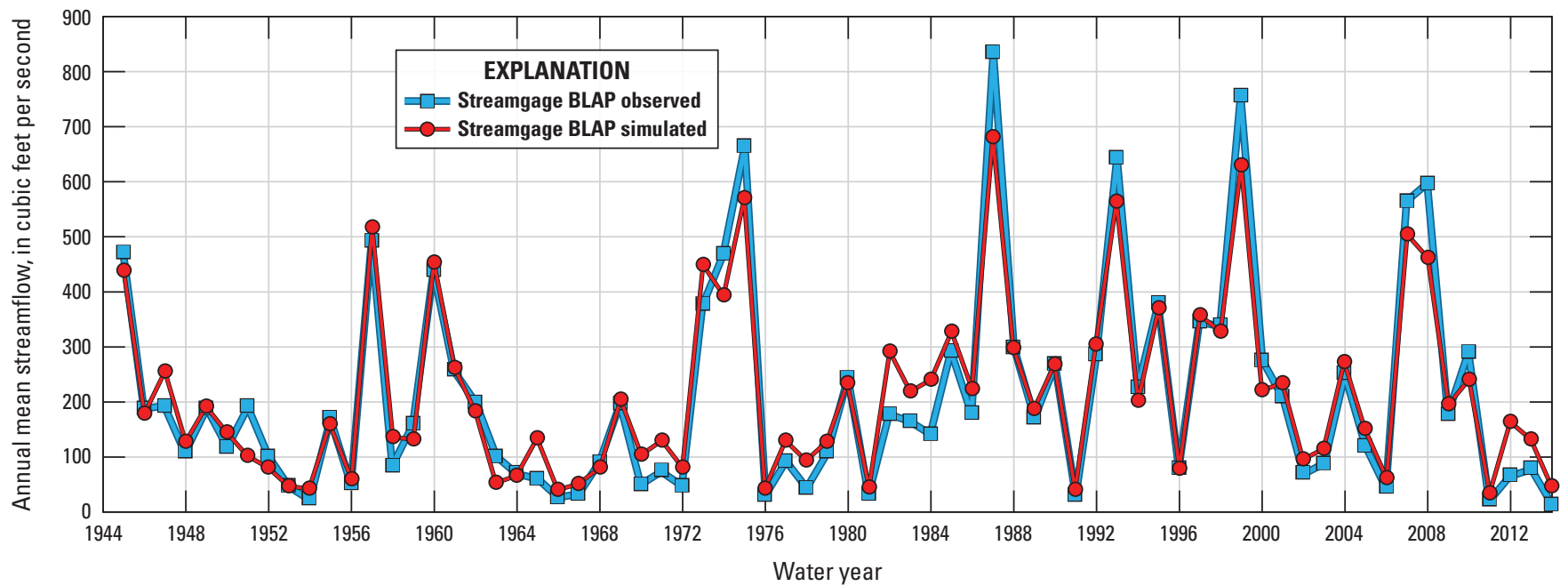

Figure 35. Comparison between simulated streamflow using the Osage Nation watershed model and observed streamflow at streamgage BLAP (U.S. Geological Survey streamgage 07153000 Black Bear Creek at Pawnee, OK), Oklahoma and Kansas: $A$, monthly mean streamflow for period of calibration, and $B$, annual mean streamflow for period of calibration.

\section{Calibration Results at Streamgage CANO}

The comparison between simulated and observed streamflow at streamgage CANO (USGS 07174700 Caney River near Ochelata, OK) indicated a satisfactory fit to observed daily streamflow for the period of calibration, water years 1957-76 (fig. 36A). The calibrated model provided a satisfactory fit to the observed streamflow for the larger storms; however, minimum flows were overestimated (figs. 36B, C). The PAEE statistic for streamgage CANO was -0.3 percent for daily streamflow (table $11 A$ ), indicating an excellent calibration result in terms of minimal estimation bias. The NSME result of 0.42 , however, indicated only a poor, but acceptable calibration to daily mean streamflow; a better fit to the low flows could increase the NSME.

In contrast to results for daily mean streamflow, calibration results for monthly mean streamflow at CANO indicated a very good fit to observed streamflow, with an NSME of 0.83 , and a good match to maximum and minimum monthly mean flows (fig. $37 \mathrm{~A}$, table $11 B$ ). Comparison between simulated and observed annual mean streamflow indicated an excellent fit to the annual flows (fig. 37B), with a PAEE of 0.0 and an NSME of 0.93 (table 11C). 
A
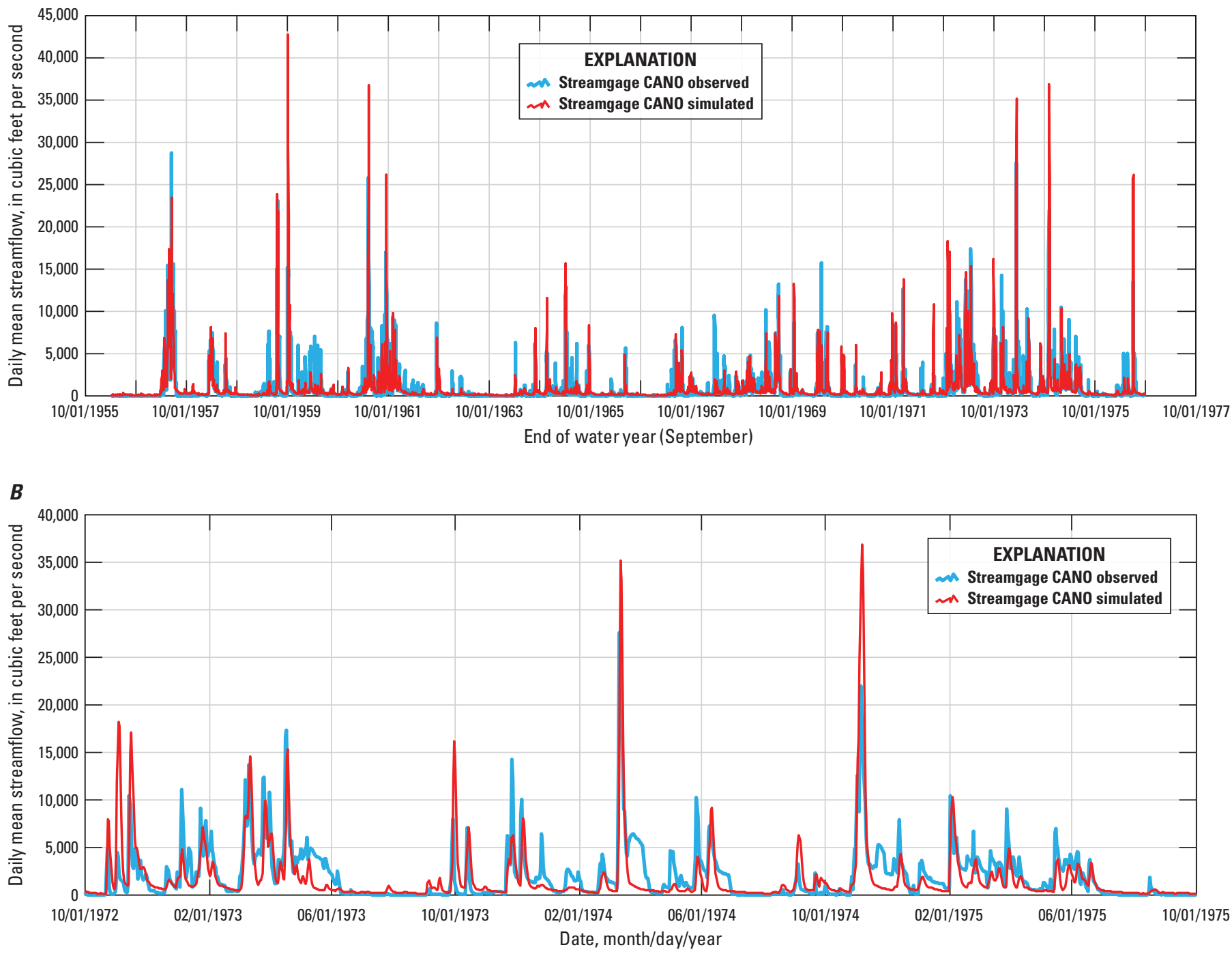

C

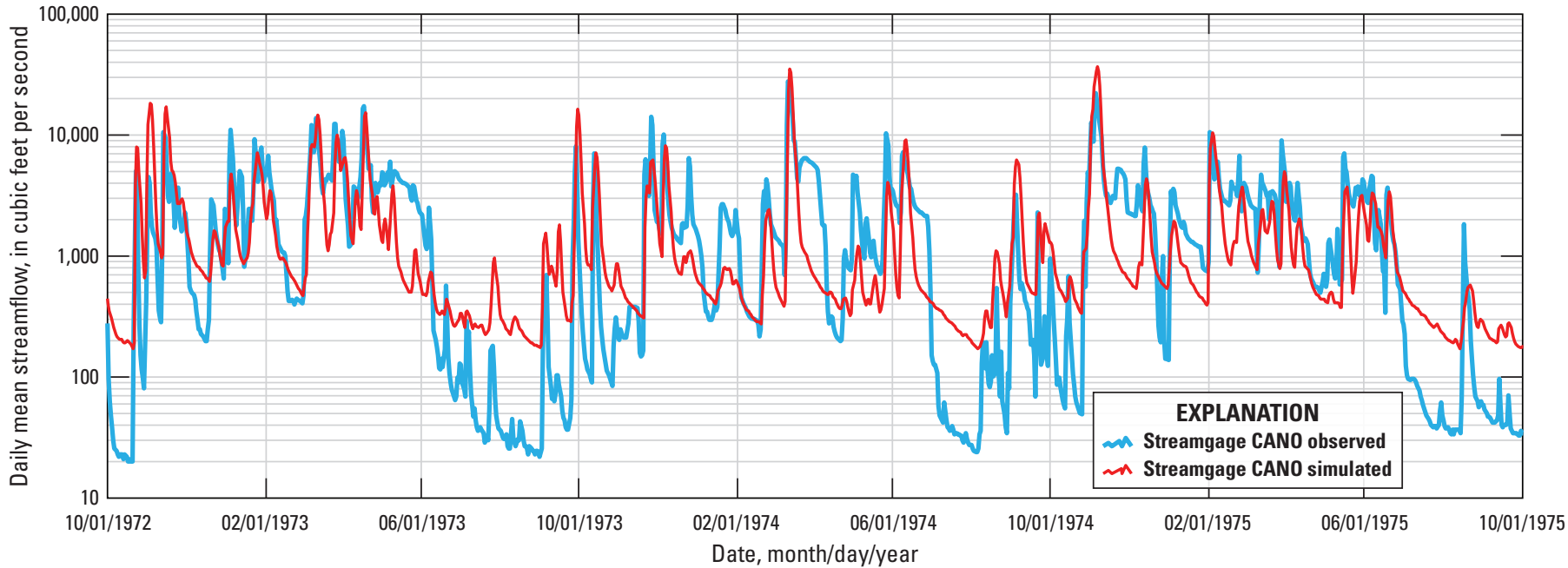

Figure 36. Comparison between simulated streamflow using the Osage Nation watershed model and observed streamflow at streamgage CANO (U.S. Geological Survey streamgage 07174700 Caney River near Ochelata, OK), Oklahoma and Kansas: $A$, daily mean streamflow for period of calibration; $B$, daily mean streamflow for water years 1973-75; and $C$, daily mean streamflow for water years 1973-75, logarithmic scale. 
$\boldsymbol{A}$

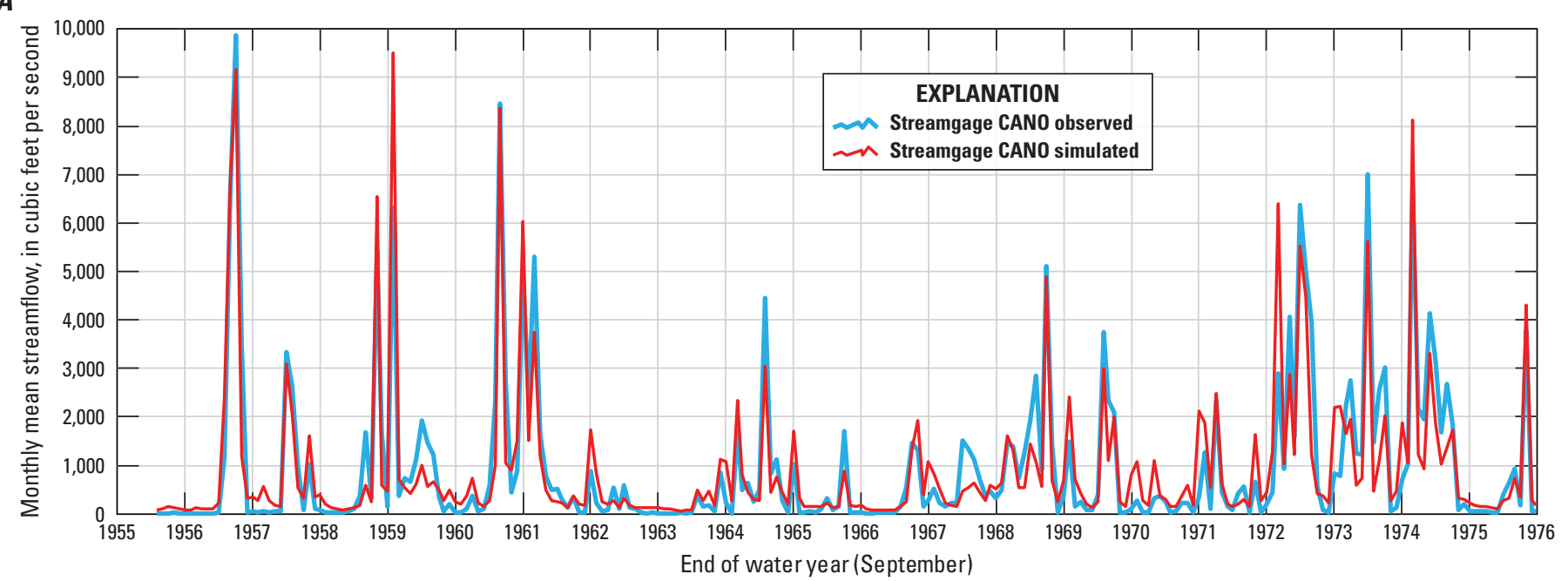

B

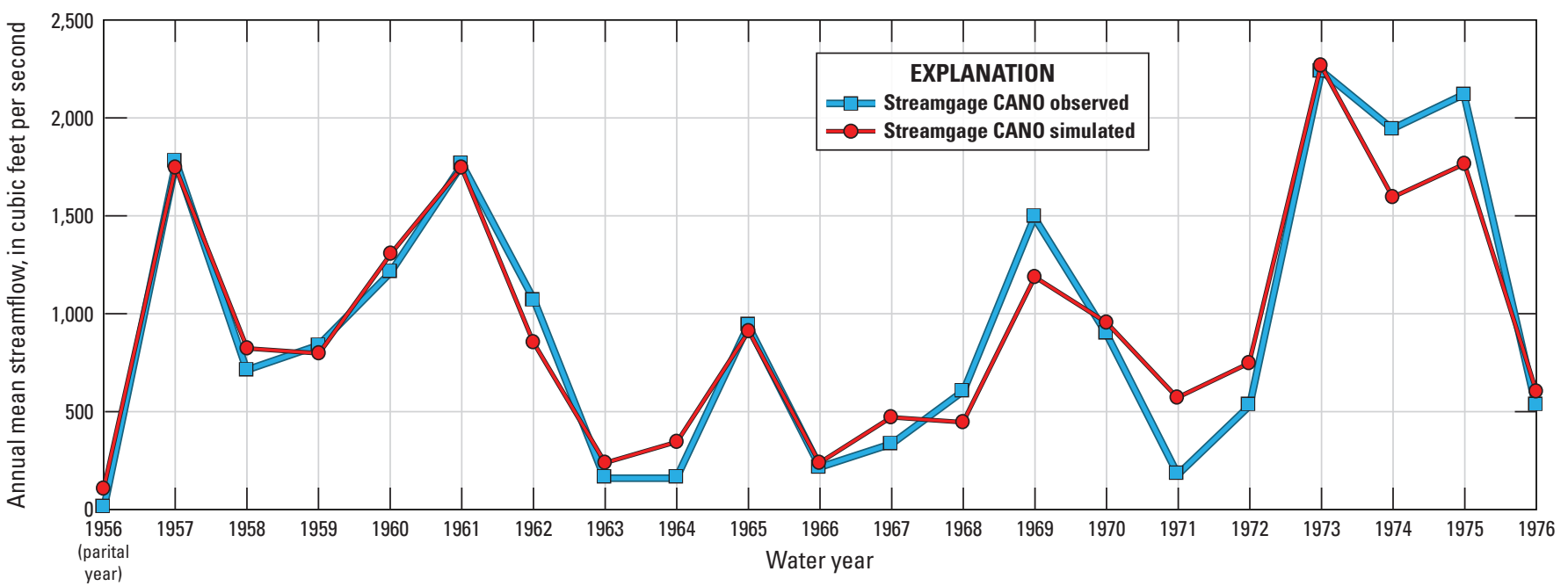

Figure 37. Comparison between simulated streamflow using the Osage Nation watershed model and observed streamflow at streamgage CANO (U.S. Geological Survey streamgage 07174700 Caney River near Ochelata, OK), Oklahoma and Kansas: $A$, monthly mean streamflow for period of calibration, and $B$, annual mean streamflow for period of calibration.

\section{Calibration Results at Streamgages AKRK and ARKT}

Obtaining a good model calibration result to observed streamflow at streamgages ARKR and ARKT on the Arkansas River was important because of the large area of the ONWM represented by their contributing drainages. Unfortunately, calibration to daily and monthly mean streamflow at ARKR (USGS 07152500 Arkansas River at Ralston, OK) was problematic because of strong flow regulation at Kaw Lake, and calibration to daily and monthly mean streamflow at ARKT (USGS 07164500 Arkansas River at Tulsa, OK) was problematic because of the flow regulation at Kaw Lake and Keystone Lake. The flow regulation tended to cause a redistribution of the daily and monthly mean streamflows, and this resulted in the calculation of negative daily and monthly mean streamflows in the development of the observed records representing only the inflow contributions from the ONWM area upstream from the streamgages. In order to mitigate the effects of flow regulation at both streamgages, model calibration was limited to recorded streamflows prior to water year 1976 at streamgage ARKR, the year Kaw Lake dam was completed, and prior to water year 1968 at streamgage ARKT, the year Keystone Lake dam was completed. In contrast to daily and monthly streamflow, the calculated ONWMcontributing annual streamflows at the two streamgages did not include negative streamflows for the calibration periods because the annual streamflows were less sensitive to the flow regulation prior to completion of the dams (fig. 38, table 11C). 
Model calibration using simulated streamflow at ARKR and ARKT was done using the difference between recorded streamflows at each streamgage and the records of river inflows at the ONWM boundary on the Arkansas River and the contributing drainage upstream from each streamgage. The calculated differences in streamflow at ARKR and ARKT were considered more appropriate for model calibration than the observed streamflow at these streamgages because the difference in flow indicated the streamflow generated from the contributing drainage in the ONWM, whereas the observed flow was largely dependent on the river inflows at the ONWM boundary, which were not simulated by the ONWM, but rather were defined by observed streamflows.

The comparison between simulated monthly and annual streamflow and the observed difference in monthly and annual streamflow at streamgage ARKR, calculated using the difference in streamflow between the observed streamflow at ARKR and the observed boundary inflows, indicated a satisfactory calibration. Variations in annual mean streamflow were well represented by the model (fig. 38A). The PAEE value of -1.7 percent and the NSME value of 0.83 indicated a good model calibration for ARKR (table 11C). A good match between simulated annual mean streamflow and the calculated difference in observed annual mean streamflow was also indicated by the NSME value of 0.84 at streamgage ARKT, downstream from ARKR. The PAEE of 4.3 percent at ARKT indicated a good calibration result in terms of estimation bias, but with some tendency of the model to overestimate streamflow at this location (table $11 C$ ). The simulation results indicated a good general fit to the recorded variations in annual flows, with a good match to most of the larger annual flows of $2,000 \mathrm{ft}^{3} / \mathrm{s}$ and greater, but with a tendency to overestimate annual streamflow after water year 1998 (fig. 38B).

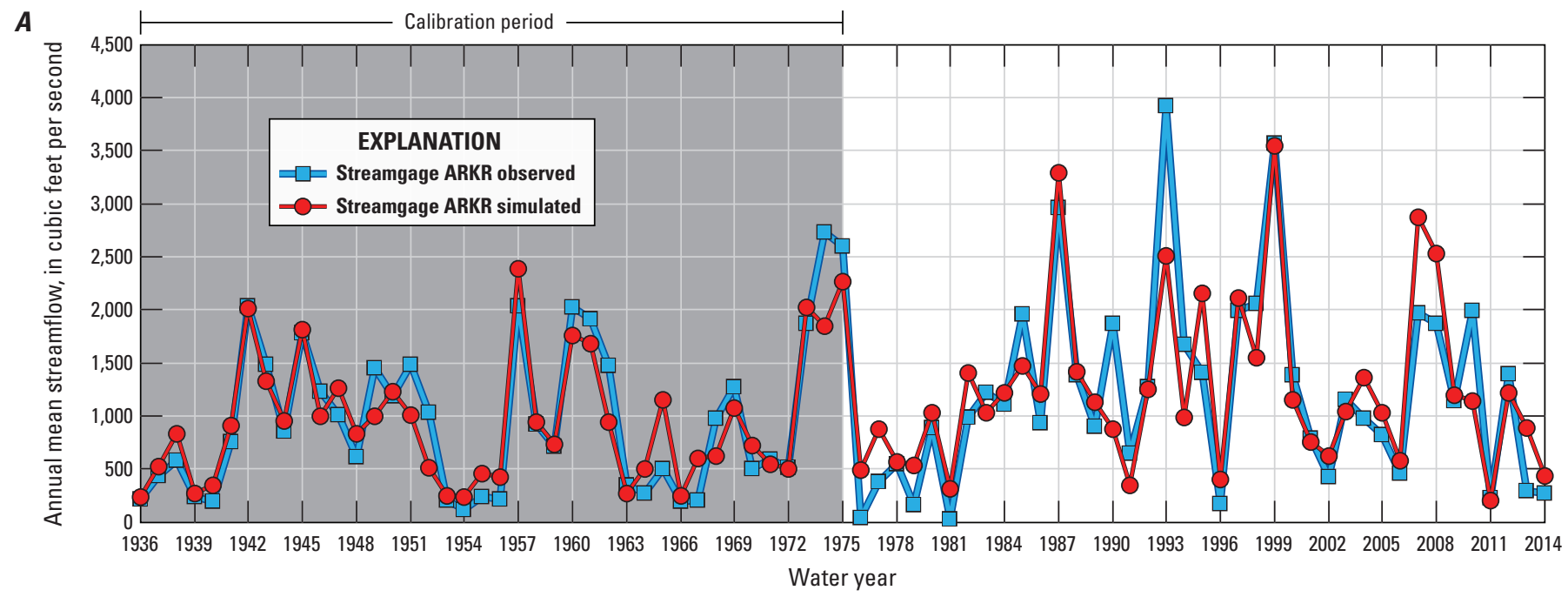

B

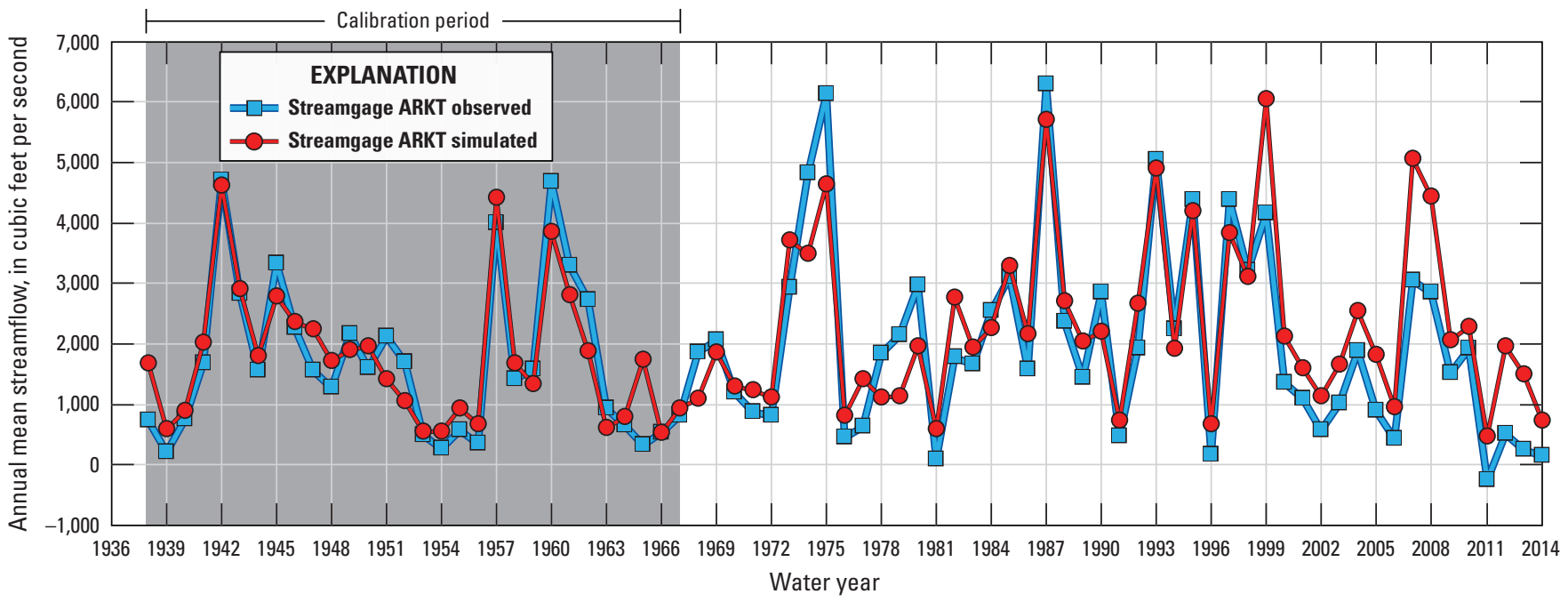

Figure 38. Comparison between simulated annual streamflow using the Osage Nation watershed model and the calculated differences in observed annual mean streamflow at, $A$, streamgage ARKR (U.S. Geological Survey streamgage 07152500 Arkansas River at Ralston, OK), and $B$, streamgage ARKT (U.S. Geological Survey streamgage 07164500 Arkansas River at Tulsa, OK), 0klahoma and Kansas. 


\section{Summary of Calibration Results}

Calibration results for stages one and two of the calibration procedure indicated an excellent model fit between simulated and observed monthly mean and mean monthly SWRAD and PET at 14 locations where continuous, multiyear records of SWRAD and PET were available (tables 8, 9). Using the calibrated parameters dday_slope, dday_intcp, and $j h \_$coef, simulated PET for water years 1915-2014 resulted in a 100-year spatially averaged mean annual PET of 51.7 inches for the ONWM area, compared to a spatially averaged 100-year mean annual precipitation of 36.1 inches for the ONWM area. The spatial distribution of simulated PET indicated a high degree of local variability as a result of topographic effects, as well as regional-scale variability where PET increases from north to south in response to the effects of latitude and the warmer air temperatures in the southern part of the ONWM area (fig. 27). Simulated mean annual PET exceeded mean annual precipitation for all locations in the ONWM area (figs. 3, 27). The mean monthly PET results indicated that PET approximately equaled or exceeded mean monthly precipitation throughout the year, and mean July PET was approximately double the mean July precipitation (fig. 5).

Calibration results for parameters affecting simulated soil moisture indicated a satisfactory model fit in terms of matching monthly mean and mean monthly soil moisture at most of the 13 locations where soil moisture data were available (table 10). There was a tendency for the model to underestimate the soil water-content fraction (water content relative to field capacity) at most locations. The calibration to observed soil moisture was used primarily to estimate the parameters transp_beg and transp_end, which control the beginning and end of growing season, the period during which transpiration is simulated in addition to bare-soil evaporation. Calibrated values for parameters controlling soil moisture (soil_rechr_max, soil_moist_max, and sat_threshold) were used to develop initial estimates for these parameters. The initial estimates were then used as a guide for the final stage of model calibration using streamflow records. Unlike parameters controlling simulated SWRAD and PET, parameters controlling simulated soil moisture were not held fixed for the final stage of model calibration.

Analysis of model sensitivity to 17 selected parameters indicated the greatest sensitivity to the parameters carea_max,smidx_coef, and smidx_exp, which control the rate of Hortonian runoff generation; the parameter slowcoef_sq, which controls the rate of interflow; the parameter ssr2gw_rate, which controls the rate of recharge; the parameter gwflow_coef, which controls the rate of groundwater discharge to streams; and the parameter soil_moist_max, which defines the root-zone storage capacity (fig. 31). Intermediate model sensitivity was indicated for the parameter pref_flow_den affecting interflow, the parameters soil2gw_max and ssr2gw_exp affecting recharge, and the parameter srain_intcp defining interception storage. A low sensitivity was indicated for the parameter snowinfil_max, related to snow hydrology, because snowfall represents only a small amount of the total precipitation in the ONWM area.

Calibration results for simulated against observed streamflow at 22 streamgages in the ONWM area indicated a good overall fit to monthly and annual mean streamflow at most streamgages (table 11). The overall model fit between simulated and observed mean streamflow at all streamgages, for the period of calibration at each streamgage, indicated a close fit to the 1-to-1 line (fig. 39). A mean period-ofcalibration streamflow of about $1,770 \mathrm{ft}^{3} / \mathrm{s}$ was simulated for the ARKT streamgage in the lower section of the Arkansas River, providing a close match to the calculated difference in observed mean period-of-calibration streamflow of about $1,700 \mathrm{ft}^{3} / \mathrm{s}$ from the contributing drainage area upstream from the streamgage and in the ONWM area (fig. 39B). The simulated mean period-of-calibration streamflow of about 960 to $970 \mathrm{ft}^{3} / \mathrm{s}$ was also in good agreement with the calculated difference in observed mean period-of-calibration streamflow of about 980 to $990 \mathrm{ft}^{3} / \mathrm{s}$ for the contributing drainage area in the ONWM area and upstream from streamgage ARKR (table 11). In addition to the good model fit to the higher overall mean period-of-calibration streamflows in the Arkansas River and the main branches of Caney River and Bird Creek, the model provided a good fit to the lower overall mean period-of-calibration streamflows observed for the smaller streams in the ONWM area (fig. 39B; table 11).

Calibration results for daily streamflow indicated a satisfactory model fit at most of the 22 streamgages. The results for daily streamflow were dependent on the use of the Muskingum flow-routing module in PRMS. The Muskingum routing method provides a dampening of peak flows as well as an increase in low flows, and this allowed for a better representation of observed flow conditions affected by lag times of more than 24 hours at many of the streamgages located on the larger streams. The dampening of peak flows and increases in low flows are also more consistent with the effects of flow regulation at reservoirs. The basic flow routing in PRMS, whereby all surface runoff, interflow, and groundwater discharge simulated during a daily time step is routed through the entire stream segment network and simulated as an outflow from the model domain, tended to overestimate the maximum daily flows at most of the streamgages, especially at streamgages on the larger streams or downstream from the larger reservoirs. 
$\boldsymbol{A}$

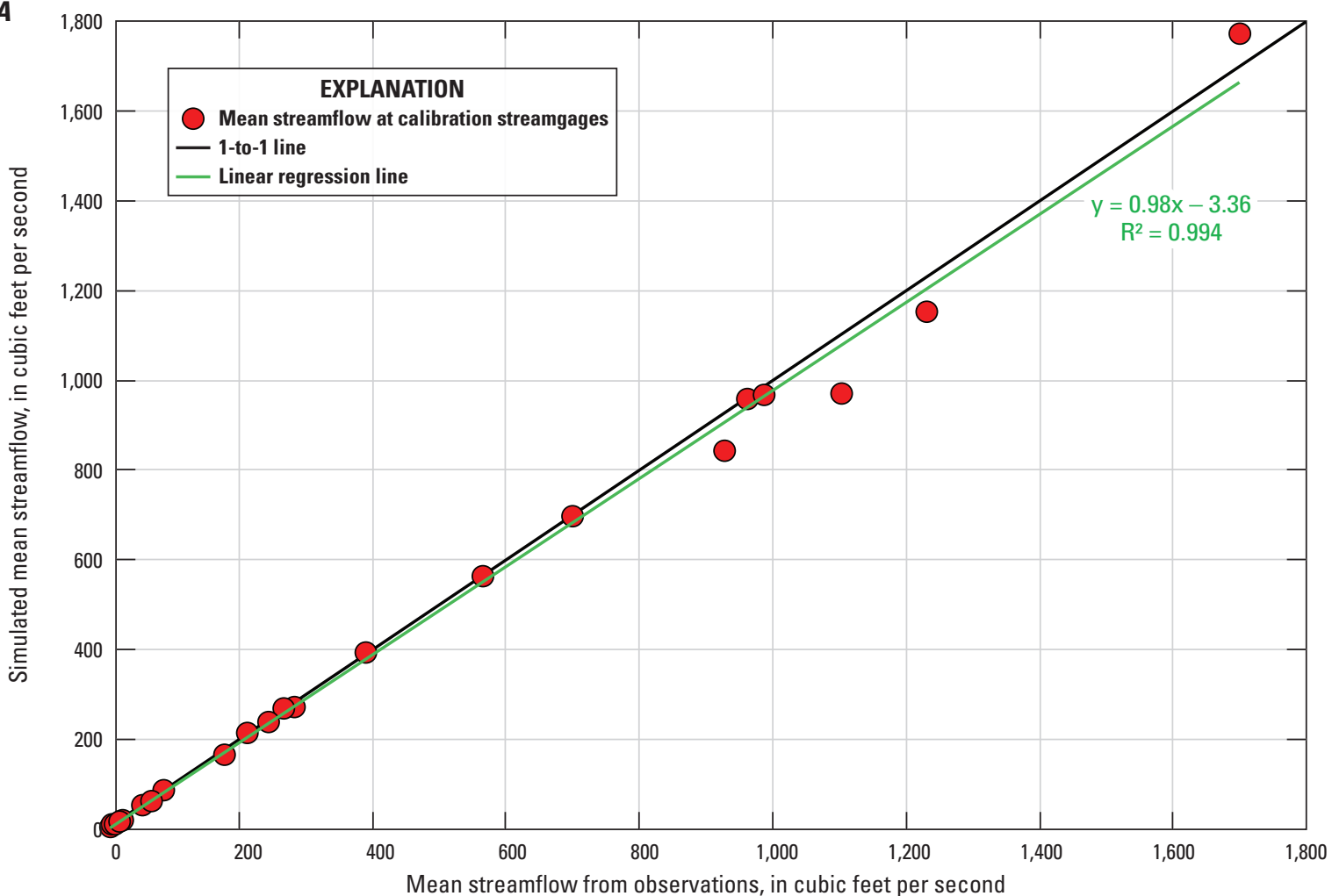

B

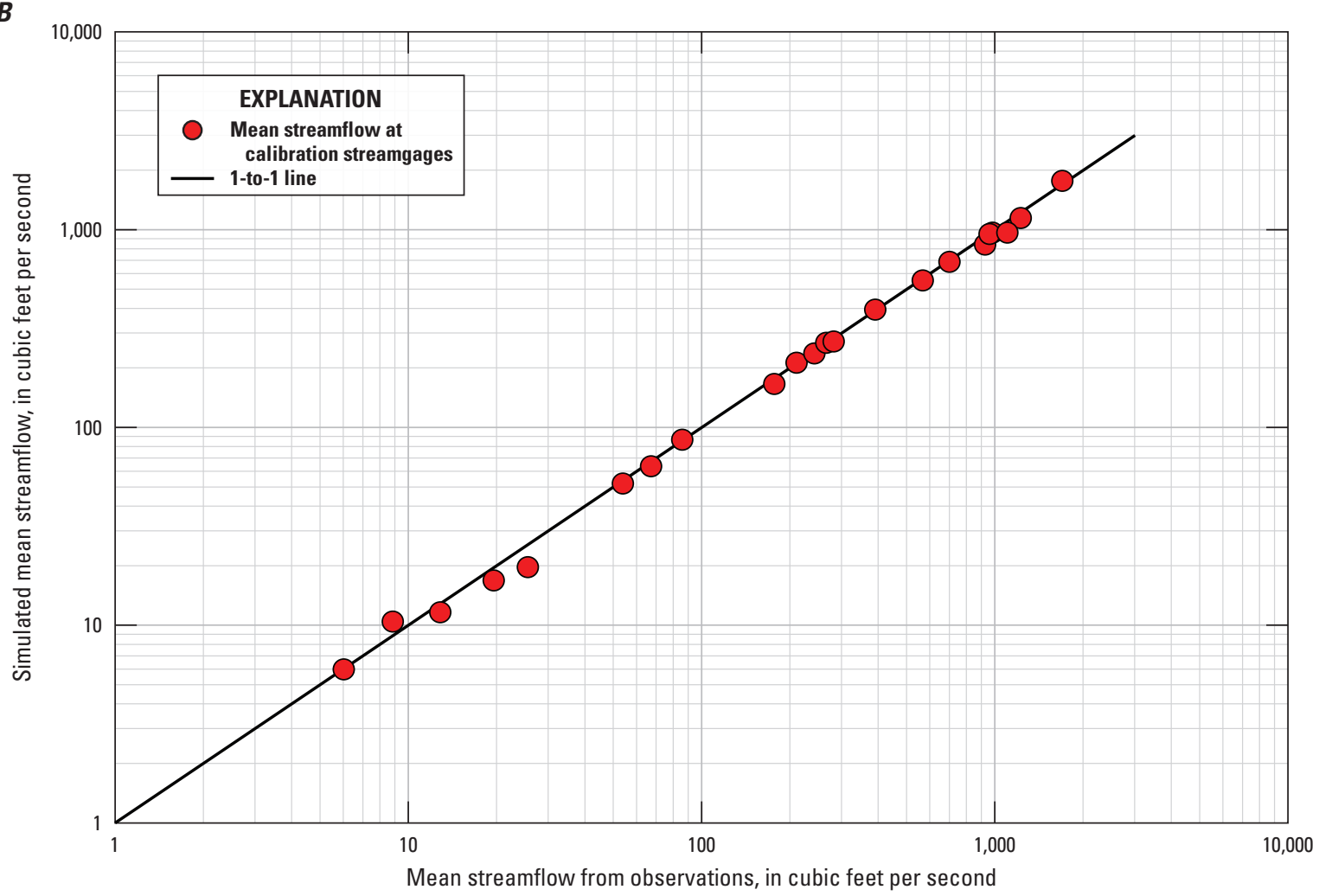

Figure 39. Simulated and observed mean period-of-calibration streamflow at 22 streamgages used to calibrate the Osage Nation watershed model, Oklahoma and Kansas: $A$, linear scale, and $B$, logarithmic scale. 
To summarize the calibration results for the 22 streamgages, a weighted mean PAEE and NSME were calculated. The weighting factors were defined for each streamgage using the average of two products consisting of (1) the the number of days, months, or years used for calibration at each gage divided by the total number of days, months, or years used for calibration for all streamgages and (2) the square root of the total contributing drainage area for each streamgage divided by the sum of the square root of the total drainage area for all streamgages. The weighted mean PAEE was calculated using the absolute value of the PAEE calculated at each individual gage. The NSME results for three streamgages, CANB, ARKR, and ARKT, were excluded from the weighted mean NSME calculation for daily mean streamflows because the daily flows were strongly affected by flow regulation at these streamgages. Calibration using daily streamflow at streamgage POLH was limited to records prior to water year 1950 because of strong flow regulation affecting daily streamflow after the completion of Heyburn reservoir in 1950.

The results for the calibrated model included weighted mean PAEE and NSME values of 4.3 percent and 0.54 for daily mean streamflow, 4.3 percent and 0.77 for monthly mean streamflow, and 4.3 percent and 0.86 for annual mean streamflow (table 11). These results met the calibration criteria of plus or minus 5 percent for the weighted mean PAEE, 0.5 for the weighted mean NSME for daily mean flows, 0.7 for the weighted mean NSME for monthly mean flows, and 0.8 for the weighted mean NSME for annual mean flows.

\section{Model Limitations}

The ONWM was considered successful for its intended purpose; however, understanding the model limitations is important for determining appropriate model applications, evaluating results, and qualitatively assessing model uncertainty. The ONWM model limitations were associated with (1) limitations in the data used to develop, calibrate, and apply the model; (2) limitations in the simplifying assumptions needed to represent the hydrologic system using a computer model; and (3) limitations in the simplifying assumptions used to represent physical processes by the computer algorithms.

The timing, magnitude, frequency, and spatial distribution of daily precipitation were the most important factors affecting simulated streamflow by the ONWM. Although a total of 203 climate stations with records of precipitation were used to develop the daily climate inputs for the ONWM, many of these stations had gaps in the record or short records (20 years or less) compared to the entire simulation period of 100 years. For many periods in the 100-year simulation period, particularly the earlier periods, only a small fraction of the 203 stations were active. For these periods, greater uncertainty was associated with the spatially interpolated climate inputs for HRUs that were far from the nearest climate station. In general, the earlier part of the simulation, prior to approximately water year 1948, was associated with greater uncertainty in climate inputs because fewer stations were active compared to the later part of the simulation. Additionally, some areas of the ONWM have a lower density of stations throughout the simulation period and therefore the simulation results for HRUs in these areas likely were associated with a higher degree of uncertainty relative to results for HRUs in areas with a higher density of climate stations.

For estimating water budgets, the daily time step used in the ONWM was considered adequate in most cases. The ONWM includes an empirical adjustment of precipitation intensity, based on a user specified monthly distribution of storm type, to account for seasonal differences between convective and frontal storm characteristics (Markstrom and others, 2015). This simplified approach might not adequately represent the high hourly precipitation rates from the more severe convective storms, which can result in a high proportion of Hortonian runoff contributing to streamflow and cause the ONWM to underestimate surface runoff and the magnitude of peak flows during some storm periods.

Many of the critical PRMS parameters, such as the $s s r 2 g w$ rate parameter controlling recharge from the soil zone and the gwsink_coef parameter controlling the rate of groundwater discharge to streams, were not measured, but rather were estimated and then adjusted during the model calibration process. The final calibrated values were considered reasonable estimates of PRMS parameters, but the values might not be representative of actual field conditions and might not agree with the measured values, if such values become available. In addition, many of the parameters were estimated using available datasets representing field conditions at the time of this study, such as land-cover type, the percentage of impervious land cover, and the percentage of forest canopy cover. At some locations, these estimated values might not be representative of conditions in the early part of the simulation period.

The parameters representing the physical characteristics of the ONWM domain, such as land cover, topography, hydrography, soil properties, and surficial geology, were held constant during the simulation period. Changes in land use and land cover caused by factors such as urbanization, wildfires, and agricultural development can cause substantial changes through time in imperviousness, vegetation type, land-cover characteristics, and stream-channel characteristics that are not represented by the model. Changes in land use and land cover during the simulation period were not accounted for by the model. The most important changes not directly represented by the ONWM are the damming of the larger rivers and streams, the building of reservoirs, and the implementation of managed river flows at different times in the simulation period. Other changes through time not represented by the model include increased diversions of surface water and changes in irrigation practices and the effects of groundwater pumping or injection. 
The ONWM used the Muskingum streamflow-routing module in PRMS-IV (Markstrom and others, 2015) to simulate streamflow in the larger river and stream channels that were modeled using stream segments. The Muskingum flow-routing method was needed because of the regional scale of the ONWM area; streamflow generated in the headwaters of the study area required traveltimes longer than 1 day to exit the ONWM area as an outflow. The longer streamflow traveltimes were also needed because of the notable flow regulation from the larger reservoirs. Simple flow-routing methods that routed all daily inflows to stream segments as daily outflows from the ONWM greatly overestimated peak streamflows. Although the Muskingum method provided a good representation of peak streamflows, there was a tendency for the method to overestimate low flows. In general, simulation results from precipitation-runoff models tend to have greater uncertainty associated with very low streamflows of about $1 \mathrm{ft}^{3} / \mathrm{s}$ and less. These very low flows are also often associated with greater measurement uncertainty in the streamflow records.

At the time of this study, the PRMS-IV computer software version used to develop the ONWM allowed for only a limited representation of the larger water bodies linked to the stream segments used to simulate the major channels because of the large number of HRUs and stream segments used in the model. Streambed leakage in stream segments could not be simulated by the ONWM using the Muskingum streamflow routing module in PRMS-IV. The depression-storage module was used to indirectly simulate the larger water bodies and the riparian areas of larger stream channels. This method of simulating water bodies did not directly account for riparian and saturated zone ET, diversions, managed flows, and infiltration of streamflow in stream segments.

An important limitation of the ONWM is that the groundwater system was represented by an empirical groundwater-storage and discharge model that does not account for the three-dimensional heterogeneity of aquifer systems and the physics of groundwater storage and flow. The groundwater reservoirs simulated by the ONWM represented only the "active" part of groundwater storage contributing to streamflow. The PRMS-simulated groundwater reservoirs do not represent the total groundwater flow system in underlying aquifers, and therefore, the ONWM cannot be used to estimate total groundwater storage in aquifers or changes in aquifer storage. This empirical simulation of the groundwater system did not allow for the representation of rejected recharge for locations with a high water table, which could cause an overestimation of recharge. Groundwater traveltimes and flow paths through the subsurface underlying the active root zone were not explicitly simulated by the ONWM. Groundwater losses due to pumping, saturated zone ET, and underflow beneath the ONWM boundary were not directly accounted for by the ONWM, although these water losses were indirectly represented by using a groundwater-sink term in the water budget.

\section{Model Application}

The ONWM simulation was run from October 1, 1909, through September 30, 2014. The 5-year period from October 1, 1909, through September 30, 1914, was used as the model initialization period. Simulations were run using two different boundary conditions: (1) simulations with river inflows at the ONWM boundary from the five upstream surface-water drainages excluded, and (2) simulations with river inflows at the ONWM boundary from the five upstream drainages included. For simulations with the river inflows excluded, water-budget results were developed and analyzed for the 100-year period of water years 1915-2014 (October 1, 1914-September 30, 2014). Simulations with the river inflows included were used to analyze results for the 77-year period of water years 1938-2014 (October 1, 1937-September 30, 2014). The results for the simulation with the river inflows included were used to develop the inflow boundary conditions for the ONIHM and were compared to results for the simulation excluding the river inflows that were used to develop the 100 -year water budget. The 100 -year simulation period could not be used to analyze the effect of the river inflows because the inflow boundary condition was dependent on the availability of daily streamflow records and, therefore, was not fully defined prior to water year 1938, the first year for which a continuous period of daily streamflow could be defined for all five river inflows.

Analysis of simulation results for water years 1915-2014 was done using (1) the 100-year mean water budget, including 100-year means for soil moisture, ET, recharge, surface runoff, and cascading flow mapped for all HRUs; (2) simulated streamflows for all stream segments, including 100-year mean streamflows, maximum and minimum monthly streamflows, and maximum and minimum daily streamflows; (3) the 100 -year time series of annual water budget and selected water-budget components, the 100-year time series of monthly recharge and streamflow, and the 100-year mean monthly distributions for water budgets and selected water-budget components. Results were developed for the entire ONWM as well as for the 32 subbasins and the 3 subbasin groups (fig. 2).

The simulation results were analyzed primarily in terms of the 100-year simulation period that excluded inflows from the five upstream drainages. The inflow boundary condition affected only the simulated streamflow in the stream segments defining the major channels in the Arkansas River surfacewater subdrainage. The ONWM did not directly account for water losses in stream segments representing the major channels and reservoirs, such as downward seepage through the soil or bedrock underlying the channels and reservoirs, or the evaporation of surface water from channels and reservoirs. These processes were indirectly simulated by using the depression storage module in PRMS for HRUs containing stream segments and water bodies, and therefore, the inflow boundary condition did not affect the water budgets of the land surface, soil zone, and groundwater reservoirs simulated by the ONWM. 


\section{Simulated Water Budget, Water Years 1915-2014}

The mean annual simulation results for water years 1915-2014 were used to define the 100-year water budget for the ONWM area. The simulated water budget included storage components as well as inflows and outflows to the hydrologic system represented by the ONWM. Simulated storage components included the snowpack, interception storage by the plant canopy, retention storage by impervious surfaces, depression storage representing water bodies and stream channels, soil-zone reservoirs (capillary, gravity, and preferential-flow reservoirs), and groundwater reservoirs. River inflows were excluded from the 100 -year water budget; therefore, precipitation was the only inflow to the hydrologic system. Outflows from the hydrologic system were ET, streamflow, and groundwater losses. In addition to these outflows, other components of the hydrologic system that were analyzed included total recharge, soil-zone recharge, seepage recharge from depressions, Hortonian and Dunnian surface runoff, interflow, and groundwater discharge to streams (base flow).

The 100-year means for selected water-budget components, including soil moisture, ET, recharge, surface runoff, and cascading flow were mapped for all HRUs. The mapped results were used to analyze the spatial variability and distribution of the water-budget components and to identify locations of maximum and minimum values in the ONWM area. The 100-year means were compiled for the 32 subbasins and summarized for the 3 subbasin groups, including the 9 upstream subbasins, the 16 ONIHM subbasins, and the 7 peripheral subbasins.

\section{Water-Budget Summary}

Precipitation accounted for 100 percent of the inflows for the 100-year water budget (water years 1915-2014) using simulations with river flows excluded (table 12). The simulated 100-year water budget for the ONWM included a basinwide (spatially-averaged) mean precipitation inflow of $36.1 \mathrm{in} / \mathrm{yr}$, or about $16.1 \mathrm{million}$ acre-ft/yr (tables 12A, B). Precipitation for the subbasins ranged from $32.7 \mathrm{in} / \mathrm{yr}$ for Middle Red Rock Creek to 38.9 in/yr for Lower Bird Creek and for Little Caney River. The upstream subbasin group was the driest at $34.3 \mathrm{in} / \mathrm{yr}$ and the peripheral subbasin group was the wettest at $37.5 \mathrm{in} / \mathrm{yr}$. The 100 -year mean precipitation inflow was balanced by the simulated changes in total water storage - soil zone reservoirs, groundwater reservoirs, depression storage, interception storage, retention storage, and snowpack - and three outflows from the ONWM-ET, streamflow, and groundwater losses. Simulated 100 -year mean annual changes in water storage were less than 0.06 percent of precipitation for all subbasins, varying from $-0.019 \mathrm{in} / \mathrm{yr}$ for the Middle Red Rock Creek subbasin to 0.009 in/yr for the Butler Creek subbasin (table 12A). The changes in storage were very small compared to other water-budget components and were not an important part of the long-term water budget. In terms of water volumes, the upstream subbasin group had a long-term decrease in stored water of 1,531 acre-ft/yr, the integrated model subbasin group had a negligible longterm increase in stored water of only $18 \mathrm{acre}-\mathrm{ft} / \mathrm{yr}$, and the peripheral subbasin group had a long-term decrease in stored water of 946 acre-ft/yr (table 12B).

The 100-year mean annual streamflow for the ONWM area in response to precipitation, expressed as an equivalent uniform water depth over the ONWM area, was $7.1 \mathrm{in} / \mathrm{yr}$ (table 12A). The simulated streamflow includes the combined contributions from surface runoff, interflow from the soil zone, and base flow from groundwater reservoirs. The mean annual streamflow depth is equivalent to a mean streamflow rate of $4,331 \mathrm{ft}^{3} / \mathrm{s}$, or an annual flow volume of about 3.1 million acre-ft/yr (table 12B). The highest streamflow equivalent water depth from a subbasin was $13.3 \mathrm{in} / \mathrm{yr}$ for the Lower Bird Creek subbasin, which had the greatest percentage of impervious area and also had the highest mean precipitation rate of $38.9 \mathrm{in} / \mathrm{yr}$. The lowest streamflow equivalent water depth from a subbasin was $3.5 \mathrm{in} / \mathrm{yr}$, simulated for the Middle Red Rock Creek subbasin, which also had the lowest mean precipitation of $32.7 \mathrm{in} / \mathrm{yr}$. Overall basinwide streamflow was somewhat positively correlated to basinwide precipitation at a correlation coefficient of 0.5 .

The Lower Arkansas River subbasin had the highest 100-year mean recharge rate (soil zone and seepage recharge combined) at $8.6 \mathrm{in} / \mathrm{yr}$, or about $97,000 \mathrm{acre}-\mathrm{ft} / \mathrm{yr}$, and the Lower Camp Creek subbasin had the lowest mean recharge rate at $0.9 \mathrm{in} / \mathrm{yr}$, or about 3,400 acre-ft/yr (tables 12A, B). The upstream subbasin group had the lowest mean recharge rate at $3.4 \mathrm{in} / \mathrm{yr}$, about 490,000 acre-ft/yr, and the ONIHM subbasin group had the highest recharge rate at $4.7 \mathrm{in} / \mathrm{yr}$, about 730,000 acre-ft/yr (tables 12A, B). In contrast to basinwide streamflow, comparison of the basinwide 100-year mean recharge to the basinwide 100-year mean precipitation for the 32 subbasins indicated that the spatial distribution of recharge on the subbasin scale was not strongly correlated to the spatial distribution of precipitation, mostly because of the effect of surface geology on recharge.

Depression storage accounted for only about 2 percent of the ONWM area; however, the concentration of water from surface runoff and interflow into depressions resulted in $2.0 \mathrm{in} / \mathrm{yr}$, or about $900,000 \mathrm{acre}-\mathrm{ft} / \mathrm{yr}$, simulated as seepage from surface water stored in depressions, accounting for 48 percent of the total recharge (tables 12A, B). The Lower Camp Creek subbasin had the lowest surface water seepage rate of $0.2 \mathrm{in} / \mathrm{yr}$, or about 22 percent of the total recharge of $0.9 \mathrm{in} / \mathrm{yr}$, and the Bear Creek subbasin had the highest basin-wide surface water seepage rate of $6.6 \mathrm{in} / \mathrm{yr}$, or about 80 percent of the total recharge of $8.2 \mathrm{in} / \mathrm{yr}$. 
Table 12A. Simulated 100-year mean water budget, water years 1915-2014, basin-wide mean water-equivalent depth, 0sage Nation watershed model (ONWM), 0klahoma and Kansas.

[-, not applicable]

\begin{tabular}{|c|c|c|c|c|c|c|c|c|c|c|}
\hline \multirow[b]{2}{*}{$\begin{array}{l}\text { Subbasin } \\
\text { or subbasin } \\
\text { group code }\end{array}$} & \multirow[b]{2}{*}{$\begin{array}{l}\text { Subbasin or } \\
\text { subbasin group name }\end{array}$} & \multicolumn{9}{|c|}{ Mean annual results, water years 1915-2014 } \\
\hline & & $\begin{array}{c}\text { Potential } \\
\text { evapotranspiration } \\
\text { (inches) }\end{array}$ & $\begin{array}{l}\text { Inflow } \\
\text { precipitation } \\
\text { (inches) }\end{array}$ & $\begin{array}{l}\text { Snowfall } \\
\text { (inches) }\end{array}$ & $\begin{array}{l}\text { Water } \\
\text { storage } \\
\text { change } \\
\text { (inches) }\end{array}$ & $\begin{array}{c}\text { Outflow } \\
\text { evapotranspiration } \\
\text { (inches) }\end{array}$ & $\begin{array}{l}\text { Outflow } \\
\text { streamflow } \\
\text { (inches) }\end{array}$ & $\begin{array}{l}\text { Surface } \\
\text { water } \\
\text { seepage } \\
\text { (inches) }\end{array}$ & $\begin{array}{l}\text { Recharge } \\
\text { (inches) }\end{array}$ & $\begin{array}{c}\text { Outflow } \\
\text { groundwater } \\
\text { loss } \\
\text { (inches) }\end{array}$ \\
\hline CEDAR & Cedar Creek & 49.2 & 38.3 & 1.2 & -0.007 & 28.7 & 8.0 & 0.3 & 1.8 & 1.6 \\
\hline SYCAM & Sycamore Creek-Caney River & 49.0 & 35.9 & 1.0 & -0.005 & 27.3 & 8.4 & 1.2 & 4.0 & 0.3 \\
\hline HBEAV & Headwaters Beaver Creek & 49.4 & 35.3 & 1.0 & -0.006 & 28.5 & 5.5 & 0.3 & 1.9 & 1.4 \\
\hline ULBEA & Upper Little Beaver Creek & 49.4 & 34.6 & 0.9 & -0.003 & 28.4 & 5.1 & 0.5 & 1.9 & 1.1 \\
\hline KAWLK & Kaw Lake-Arkansas River & 48.9 & 35.1 & 1.1 & -0.005 & 27.0 & 7.2 & 1.3 & 3.2 & 0.9 \\
\hline SALTF & Salt Fork Arkansas River & 52.8 & 33.4 & 0.9 & -0.013 & 26.7 & 5.0 & 1.2 & 4.1 & 1.8 \\
\hline MREDR & Middle Red Rock Creek & 53.4 & 32.7 & 0.9 & -0.019 & 27.2 & 3.5 & 0.9 & 3.6 & 2.0 \\
\hline LBEAR & Lower Black Bear Creek & 54.1 & 33.6 & 0.8 & -0.014 & 27.9 & 5.4 & 1.2 & 3.2 & 0.3 \\
\hline LCAMP & Lower Camp Creek & 53.4 & 35.8 & 0.8 & -0.008 & 29.7 & 5.4 & 0.2 & 0.9 & 0.7 \\
\hline- & Upstream subbasin group & 51.5 & 34.3 & 0.9 & -0.011 & 27.4 & 6.0 & 1.1 & 3.4 & 1.0 \\
\hline MCANE & Middle Caney River & 49.4 & 36.4 & 1.0 & 0.002 & 27.9 & 8.4 & 1.5 & 4.2 & 0.1 \\
\hline BUTLR & Butler Creek & 51.3 & 36.7 & 1.0 & 0.009 & 28.1 & 7.8 & 2.2 & 4.3 & 0.7 \\
\hline SANDC & Sand Creek & 50.8 & 37.1 & 1.0 & 0.005 & 28.6 & 8.0 & 1.6 & 3.5 & 0.5 \\
\hline CBIRD & Charlie Creek-Bird Creek & 52.0 & 37.7 & 0.9 & 0.000 & 29.2 & 8.0 & 1.9 & 4.0 & 0.5 \\
\hline HOMCK & Rock Creek-Hominy Creek & 52.5 & 37.1 & 0.9 & 0.002 & 28.2 & 7.8 & 2.9 & 5.0 & 1.0 \\
\hline DELAW & Delaware Creek & 52.1 & 38.4 & 0.9 & -0.014 & 29.7 & 8.7 & 1.1 & 3.2 & 0.1 \\
\hline KEYAR & Keystone Lake-Arkansas River & 53.7 & 37.1 & 0.9 & -0.005 & 26.8 & 7.7 & 5.4 & 7.0 & 2.6 \\
\hline UCANE & Upper Caney River & 49.2 & 36.8 & 1.0 & -0.001 & 27.2 & 6.9 & 2.4 & 5.0 & 2.7 \\
\hline LBEAV & Lower Beaver Creek & 50.3 & 34.8 & 0.9 & 0.002 & 27.4 & 6.5 & 2.6 & 4.1 & 0.9 \\
\hline BEARC & Bear Creek & 51.0 & 34.7 & 0.9 & 0.008 & 24.4 & 8.0 & 6.6 & 8.2 & 2.4 \\
\hline SALTC & Salt Creek & 50.6 & 35.6 & 0.9 & -0.004 & 28.8 & 5.9 & 0.8 & 2.2 & 0.9 \\
\hline KAWDM & Kaw Dam-Arkansas River & 52.2 & 34.7 & 0.9 & 0.002 & 25.4 & 6.9 & 5.0 & 6.7 & 2.3 \\
\hline COONC & Coon Creek-Red Rock Creek & 53.6 & 34.2 & 0.8 & -0.013 & 28.6 & 4.5 & 1.2 & 3.4 & 1.1 \\
\hline SLARK & Sooner Lake-Arkansas River & 53.2 & 35.4 & 0.9 & -0.001 & 28.0 & 6.3 & 2.8 & 4.6 & 1.1 \\
\hline CBEAR & $\begin{array}{l}\text { Crystal Creek-Black Bear } \\
\text { Creek }\end{array}$ & 53.6 & 36.0 & 0.8 & -0.013 & 28.9 & 5.0 & 1.9 & 4.2 & 2.2 \\
\hline UBIRD & Upper Bird Creek & 51.0 & 37.5 & 0.9 & 0.007 & 28.4 & 8.5 & 2.2 & 5.0 & 0.5 \\
\hline
\end{tabular}


Table 12A. Simulated 100-year mean water budget, water years 1915-2014, basin-wide mean water-equivalent depth, Osage Nation watershed model (0NWM), Oklahoma and Kansas.-Continued

$[-$, not applicable $]$

\begin{tabular}{|c|c|c|c|c|c|c|c|c|c|c|}
\hline \multirow[b]{2}{*}{$\begin{array}{l}\text { Subbasin } \\
\text { or subbasin } \\
\text { group code }\end{array}$} & \multirow[b]{2}{*}{$\begin{array}{l}\text { Subbasin or } \\
\text { subbasin group name }\end{array}$} & \multicolumn{9}{|c|}{ Mean annual results, water years 1915-2014 } \\
\hline & & $\begin{array}{c}\text { Potential } \\
\text { evapotranspiration } \\
\text { (inches) }\end{array}$ & $\begin{array}{l}\text { Inflow } \\
\text { precipitation } \\
\text { (inches) }\end{array}$ & $\begin{array}{l}\text { Snowfall } \\
\text { (inches) }\end{array}$ & $\begin{array}{l}\text { Water } \\
\text { storage } \\
\text { change } \\
\text { (inches) }\end{array}$ & $\begin{array}{c}\text { Outflow } \\
\text { evapotranspiration } \\
\text { (inches) }\end{array}$ & $\begin{array}{l}\text { Outflow } \\
\text { streamflow } \\
\text { (inches) }\end{array}$ & $\begin{array}{l}\text { Surface } \\
\text { water } \\
\text { seepage } \\
\text { (inches) }\end{array}$ & $\begin{array}{l}\text { Recharge } \\
\text { (inches) }\end{array}$ & $\begin{array}{c}\text { Outflow } \\
\text { groundwater } \\
\text { loss } \\
\text { (inches) }\end{array}$ \\
\hline ONIHM & $\begin{array}{l}\text { Osage Nation integrated } \\
\text { hydrologic model }\end{array}$ & 51.7 & 36.5 & 0.9 & 0.000 & 27.9 & 7.3 & 2.7 & 4.7 & 1.2 \\
\hline LCANE & Lower Caney River & 51.0 & 37.9 & 1.0 & -0.001 & 29.9 & 7.8 & 1.1 & 3.6 & 0.2 \\
\hline LBIRD & Lower Bird Creek & 52.7 & 38.9 & 0.9 & -0.016 & 25.3 & 13.3 & 1.5 & 5.2 & 0.3 \\
\hline LWARK & Lower Arkansas River & 52.7 & 38.7 & 0.9 & -0.012 & 24.8 & 12.3 & 5.2 & 8.6 & 1.6 \\
\hline LICAN & Little Caney River & 48.3 & 38.9 & 1.2 & 0.000 & 28.3 & 7.9 & 1.7 & 5.0 & 2.7 \\
\hline SKULL & Skull Creek-Cimarron River & 54.0 & 34.6 & 0.8 & -0.010 & 27.8 & 5.4 & 2.3 & 3.7 & 1.4 \\
\hline KEYCR & Keystone Lake-Cimarron River & 53.5 & 37.0 & 0.9 & -0.006 & 28.6 & 6.2 & 3.4 & 5.0 & 2.3 \\
\hline POLEC & Polecat Creek & 53.2 & 38.1 & 0.8 & -0.011 & 30.0 & 7.9 & 1.4 & 3.2 & 0.3 \\
\hline- & Peripheral subbasin group & 52.0 & 37.5 & 0.9 & -0.006 & 28.3 & 7.8 & 2.2 & 4.5 & 1.3 \\
\hline ONWM & Osage Nation watershed model & 51.7 & 36.1 & 0.9 & -0.006 & 27.9 & 7.1 & 2.0 & 4.2 & 1.2 \\
\hline
\end{tabular}

Table 12B. Simulated 100-year average water budget, water years 1915-2014, basin-wide average water volumes, 0sage Nation watershed model (0NWM), Oklahoma and Kansas.

[Values may not sum due to rounding. Abbreviations: acre-ft/yr, acre feet per year; —, not applicable]

\begin{tabular}{|c|c|c|c|c|c|c|c|c|c|c|}
\hline \multirow[b]{2}{*}{$\begin{array}{l}\text { Subbasin } \\
\text { or subbasin } \\
\text { group code }\end{array}$} & \multirow[b]{2}{*}{$\begin{array}{c}\text { Subbasin or } \\
\text { subbasin group name }\end{array}$} & \multicolumn{9}{|c|}{ Mean annual results, water years 1915-2014 } \\
\hline & & $\begin{array}{c}\text { Potential } \\
\text { evapotranspiration } \\
\text { (acre-ft/yr) }\end{array}$ & $\begin{array}{c}\text { Inflow } \\
\text { precipitation } \\
\text { (acre-ft/yr) }\end{array}$ & $\begin{array}{l}\text { Snowfall } \\
\text { (acre-ft/yr) }\end{array}$ & $\begin{array}{c}\text { Water } \\
\text { storage } \\
\text { change } \\
\text { (acre-ft/yr) }\end{array}$ & $\begin{array}{c}\text { Outflow } \\
\text { evapotranspiration } \\
\text { (acre-ft/yr) }\end{array}$ & $\begin{array}{c}\text { Outflow } \\
\text { streamflow } \\
\text { (acre-ft/yr) }\end{array}$ & $\begin{array}{c}\text { Surface } \\
\text { water } \\
\text { seepage } \\
\text { (acre-ft/yr) }\end{array}$ & $\begin{array}{c}\text { Recharge } \\
\text { (acre-ft/yr) }\end{array}$ & $\begin{array}{c}\text { Outflow } \\
\text { groundwater } \\
\text { loss } \\
\text { (acre-ft/yr) }\end{array}$ \\
\hline CEDAR & Cedar Creek & 102,700 & 79,840 & 2,401 & -14 & 59,880 & 16,670 & 677 & 3,751 & 3,302 \\
\hline SYCAM & Sycamore Creek-Caney River & $1,134,000$ & 832,000 & 23,580 & -118 & 630,800 & 194,600 & 28,770 & 92,900 & 6,712 \\
\hline HBEAV & Headwaters Beaver Creek & 97,240 & 69,530 & 1,914 & -11 & 55,980 & 10,840 & 669 & 3,755 & 2,724 \\
\hline ULBEA & Upper Little Beaver Creek & 114,500 & 80,350 & 2,184 & -7 & 65,980 & 11,870 & 1,109 & 4,462 & 2,497 \\
\hline KAWLK & Kaw Lake-Arkansas River & $1,789,000$ & $1,283,000$ & 39,250 & -188 & 987,400 & 264,400 & 47,770 & 117,300 & 31,870 \\
\hline SALTF & Salt Fork Arkansas River & $1,056,000$ & 667,800 & 17,100 & -264 & 533,500 & 99,540 & 24,910 & 81,870 & 35,050 \\
\hline MREDR & Middle Red Rock Creek & $1,312,000$ & 802,700 & 21,100 & -470 & 667,200 & 86,840 & 22,230 & 88,620 & 49,120 \\
\hline LBEAR & Lower Black Bear Creek & $1,619,000$ & $1,006,000$ & 25,010 & -427 & 836,300 & 160,300 & 36,700 & 95,640 & 10,100 \\
\hline LCAMP & Lower Camp Creek & 203,900 & 136,600 & 3,223 & -31 & 113,400 & 20,530 & 833 & 3,419 & 2,681 \\
\hline
\end{tabular}


Table 12B. Simulated 100-year average water budget, water years 1915-2014, basin-wide average water volumes, Osage Nation watershed model (ONWM), Oklahoma and Kansas.-Continued

[Values may not sum due to rounding. Abbreviations: acre-ft/yr, acre feet per year; —, not applicable]

\begin{tabular}{|c|c|c|c|c|c|c|c|c|c|c|}
\hline \multirow[b]{2}{*}{$\begin{array}{c}\text { Subbasin } \\
\text { or subbasin } \\
\text { group code }\end{array}$} & \multirow[b]{2}{*}{$\begin{array}{c}\text { Subbasin or } \\
\text { subbasin group name }\end{array}$} & \multicolumn{9}{|c|}{ Mean annual results, water years 1915-2014 } \\
\hline & & $\begin{array}{c}\text { Potential } \\
\text { evapotranspiration } \\
\text { (acre-ft/yr) }\end{array}$ & $\begin{array}{c}\text { Inflow } \\
\text { precipitation } \\
\text { (acre-ft/yr) }\end{array}$ & $\begin{array}{l}\text { Snowfall } \\
\text { (acre-ft/yr) }\end{array}$ & $\begin{array}{c}\text { Water } \\
\text { storage } \\
\text { change } \\
\text { (acre-ft/yr) }\end{array}$ & $\begin{array}{c}\text { Outflow } \\
\text { evapotranspiration } \\
\text { (acre-ft/yr) }\end{array}$ & $\begin{array}{c}\text { Outflow } \\
\text { streamflow } \\
\text { (acre-ft/yr) }\end{array}$ & $\begin{array}{c}\text { Surface } \\
\text { water } \\
\text { seepage } \\
\text { (acre-ft/yr) }\end{array}$ & $\begin{array}{l}\text { Recharge } \\
\text { (acre-ft/yr) }\end{array}$ & $\begin{array}{c}\text { Outflow } \\
\text { groundwater } \\
\text { loss } \\
\text { (acre-ft/yr) }\end{array}$ \\
\hline- & Upstream subbasin group & $7,429,000$ & $4,958,000$ & 135,800 & $-1,531$ & $3,950,000$ & 865,600 & 163,700 & 491,700 & 144,100 \\
\hline MCANE & Middle Caney River & 223,400 & 164,700 & 4,314 & 8 & 126,100 & 38,200 & 6,956 & 18,890 & 401 \\
\hline BUTLR & Butler Creek & 69,420 & 49,660 & 1,356 & 12 & 38,120 & 10,580 & 2,975 & 5,756 & 958 \\
\hline SANDC & Sand Creek & 652,200 & 476,100 & 12,320 & 67 & 367,300 & 102,400 & 20,000 & 45,170 & 6,361 \\
\hline CBIRD & Charlie Creek-Bird Creek & 676,100 & 489,800 & 11,780 & 5 & 379,200 & 104,600 & 25,310 & 52,570 & 6,101 \\
\hline HOMCK & Rock Creek-Hominy Creek & $1,158,000$ & 817,500 & 19,120 & 35 & 622,900 & 172,200 & 63,270 & 110,300 & 22,330 \\
\hline DELAW & Delaware Creek & 144,800 & 106,700 & 2,548 & -40 & 82,470 & 24,060 & 3,071 & 9,019 & 186 \\
\hline KEYAR & Keystone Lake-Arkansas River & 806,900 & 557,300 & 13,440 & -70 & 402,100 & 115,800 & 80,450 & 104,800 & 39,510 \\
\hline UCANE & Upper Caney River & 619,800 & 463,200 & 12,480 & -17 & 342,600 & 86,570 & 30,040 & 62,550 & 34,030 \\
\hline LBEAV & Lower Beaver Creek & 310,300 & 214,900 & 5,481 & 12 & 169,000 & 40,340 & 15,910 & 25,360 & 5,558 \\
\hline BEARC & Bear Creek & 181,000 & 123,200 & 3,170 & 27 & 86,550 & 28,250 & 23,590 & 28,980 & 8,369 \\
\hline SALTC & Salt Creek & 788,200 & 555,000 & 14,020 & -56 & 448,600 & 91,930 & 12,000 & 34,580 & 14,530 \\
\hline KAWDM & Kaw Dam-Arkansas River & 395,800 & 263,000 & 6,490 & 19 & 192,900 & 52,650 & 37,570 & 51,130 & 17,350 \\
\hline COONC & Coon Creek-Red Rock Creek & 76,450 & 48,840 & 1,168 & -19 & 40,830 & 6,472 & 1,649 & 4,915 & 1,548 \\
\hline SLARK & Sooner Lake-Arkansas River & $1,141,000$ & 760,000 & 18,910 & -31 & 601,400 & 135,800 & 59,220 & 98,160 & 22,850 \\
\hline CBEAR & Crystal Creek-Black Bear Creek & 90,880 & 61,170 & 1,416 & -21 & 49,010 & 8,495 & 3,211 & 7,141 & 3,680 \\
\hline UBIRD & Upper Bird Creek & 675,900 & 496,600 & 12,410 & 88 & 376,600 & 112,800 & 29,470 & 65,710 & 7,163 \\
\hline ONIHM & $\begin{array}{c}\text { Osage Nation integrated } \\
\text { hydrologic model }\end{array}$ & $8,010,000$ & $5,647,000$ & 140,400 & 18 & $4,326,000$ & $1,131,000$ & 414,700 & 725,000 & 190,900 \\
\hline LCANE & Lower Caney River & $1,396,000$ & $1,037,000$ & 26,620 & -33 & 819,000 & 213,300 & 29,940 & 98,820 & 4,941 \\
\hline LBIRD & Lower Bird Creek & 504,200 & 371,900 & 8,865 & -149 & 242,200 & 127,400 & 14,680 & 49,870 & 2,448 \\
\hline LWARK & Lower Arkansas River & 595,900 & 437,700 & 10,180 & -132 & 280,500 & 139,300 & 59,110 & 97,140 & 18,130 \\
\hline LICAN & Little Caney River & $1,343,000$ & $1,080,000$ & 32,550 & -8 & 785,800 & 218,600 & 48,620 & 137,800 & 75,470 \\
\hline SKULL & Skull Creek-Cimarron River & $1,486,000$ & 953,100 & 21,710 & -269 & 766,600 & 149,100 & 62,680 & 102,900 & 37,670 \\
\hline KEYCR & Keystone Lake-Cimarron River & $1,199,000$ & 829,100 & 19,500 & -141 & 640,800 & 137,700 & 77,060 & 111,300 & 50,730 \\
\hline POLEC & Polecat Creek & $1,050,000$ & 751,900 & 16,000 & -214 & 591,200 & 155,700 & 27,780 & 63,930 & 5,203 \\
\hline - & Peripheral subbasin group & $7,574,000$ & $5,461,000$ & 135,400 & -946 & $4,126,000$ & $1,141,000$ & 319,900 & 661,700 & 194,600 \\
\hline ONWM & Osage Nation watershed model & $23,010,000$ & $16,070,000$ & 411,600 & $-2,458$ & $12,400,000$ & $3,138,000$ & 898,200 & $1,878,000$ & 529,600 \\
\hline
\end{tabular}


Results for the ONWM and ONIHM areas indicated that most of the simulated recharge was discharged back to the stream network as the base-flow component of streamflow. Base flow accounted for 72 percent of recharge (3.0 in/yr) for the ONWM area and 74 percent of recharge (3.4 in/yr) for the ONIHM area. A smaller amount of the recharge, averaging $1.2 \mathrm{in} / \mathrm{yr}$ for the ONWM and ONIHM areas (about 0.5 million acre- $\mathrm{ft} / \mathrm{yr}$ for the ONWM area and 0.2 million acre-ft/yr for the ONIHM area), or about 28 to 26 percent of total recharge, respectively, was simulated as a groundwater outflow or loss. This simulated net groundwater loss amounted to about 3.3 to 3.4 percent of precipitation in the ONWM and ONIHM areas and was included in the ONWM to represent groundwater processes that were not directly simulated, such as groundwater ET, groundwater pumping, and groundwater underflow. These groundwater processes are more appropriately simulated using groundwater-flow models (fig. 40).

The largest outflow from the ONWM hydrologic system was ET, accounting for 77.2 percent of the total outflow from the ONWM (fig. 40A). Streamflow accounted for 19.5 percent of the total outflow. The proportion of water outflows from ET, streamflow, and groundwater losses were fairly consistent among the subbasin groups, with ET accounting for the largest percentage of water loss for all subbasin groups, varying from 75.6 percent for the peripheral subbasin group (fig. 40C) to 79.7 percent for the upstream subbasin group (fig. $40 B$ ). Groundwater losses accounted for the smallest percentage of water losses for all subbasin groups, ranging from 2.9 percent for the upstream subbasin group (fig. $40 B$ ) to 3.6 percent for the peripheral subbasin group (fig. $40 C$ ). Streamflow ranged from 17.5 percent of all losses for the upstream subbasin group (fig. $40 B$ ) to 20.9 percent for the peripheral subbasin group (fig. 40C). Results for the ONIHM were intermediate between the upstream and peripheral subbasins (fig. 40D).
$\boldsymbol{A}$

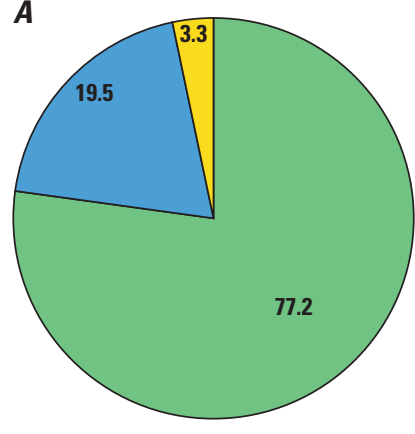

Osage Nation watershed model (ONWM)

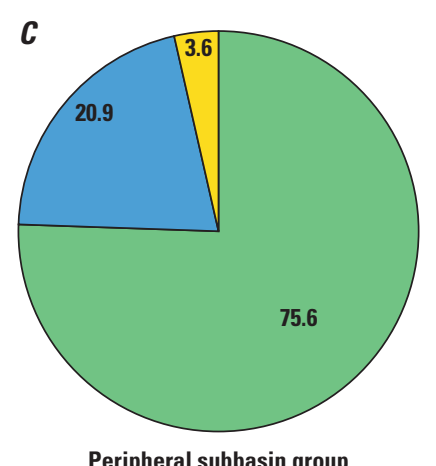

Peripheral subbasin group

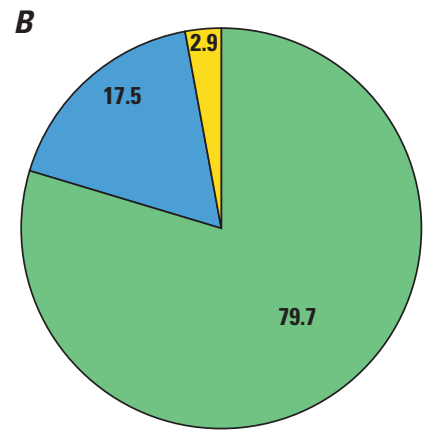

Upstream subbasin group

D

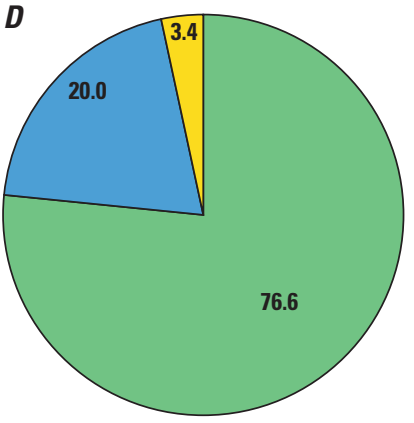

Osage Nation integrated hydrologic model (ONIHM) subbasin group

\section{EXPLANATION}

Evapotranspiration

Groundwater losses

Figure 40. Simulated outflows as a percentage of precipitation for water years 1915-2014 using the Osage Nation watershed model, Oklahoma and Kansas, for the areas of $A$, the Osage Nation watershed model; $B$, the upstream subbasin group; $C$, the peripheral subbasin group; and $D$, the integrated hydrologic model subbasin group. 


\section{Soil Moisture}

Soil moisture is the amount of water in the soil-zone reservoir simulated by the ONWM and is the amount of water in the root zone available for ET, recharge, and interflow. Soil moisture was the primary water-storage component simulated by the ONWM. Soil moisture was simulated as a waterequivalent depth for the area of each HRU and included the combined water-equivalent depth for the capillary reservoir, the gravity reservoir, and the preferential flow reservoir for the soil zone of each HRU.

The simulated 100-year mean soil moisture, expressed as a water-equivalent depth averaged over the ONWM area, was 2.4 inches and varied spatially from high values of 3.2 to 17.0 inches for downstream HRUs in the lower sections of cascading flow paths to low values of 0.05 to 1.6 inches for HRUs with steep slopes, thin soil cover, sandy or rocky soils, and sparse vegetation cover (fig. 41). Low soil moistures of 1.6 inches and less were simulated for sandy soils on steeper slopes underlain by permeable bedrock in the central and eastern parts of Osage Nation, and for the drier western parts of the ONWM. Intermediate soil moistures of 1.61 to 2.4 inches were simulated for clayey soils on low slopes throughout the northern, eastern, and western parts of the ONWM, included the western part of Osage Nation. Higher mean soil-moisture values of 2.41 to 17.0 inches were simulated for HRUs in forested and riparian areas along cascading streamlines and HRUs containing stream segments because these HRUs were assumed to have deeper root zones and therefore were assigned higher storage capacities for the soil-zone reservoirs. In addition, HRUs along cascading streamlines representing the smaller first-order tributaries and HRUs s containing stream segments representing the main stream channels received inflows of surface runoff and interflow from upstream HRUs, and this resulted in much wetter soils compared to HRUs in inter-channel areas and on drainage divides. Mean soil-moisture amounts of 2.41 to 4.0 inches and greater were also simulated for the forested areas in the eastern part of the Osage Nation and the southern part of the ONWM area, as well as for forested zones along riparian areas throughout the ONWM area. The higher soilmoisture amounts were simulated for these areas because thicker soils with deeper root zones were estimated for HRUs where there is denser forest-canopy cover and along valley bottoms where there are riparian areas. In addition to these locations with thicker soils, mean soil moistures of 2.41 inches and greater were simulated for a higher percentage of HRUs in the wetter eastern part of the ONWM area compared to the drier western part.

Compared to the high mean soil moistures simulated for flat-lying to gently sloping forested areas and valley bottoms with deeper root zones, 100-year mean soil moisture amounts of 2.0 inches and less were simulated for HRUs that have steep slopes and relatively shallow root zones, such as grasslands, developed agricultural lands, and developed urban areas. The lowest mean soil moistures of 0.8 inch and less were simulated for urban areas with a high percentage of impervious land cover, such as the Tulsa metropolitan area in the southeastern part of the ONWM area. Areas with simulated 100-year mean soil moisture of 1 inch or less included the western part of the ONWM area and were associated with agricultural-land cover (cultivated crops) and relatively low precipitation amounts. It should be noted, however, that the ONWM did not account for crop and landscape irrigation, which would likely cause an increase in mean soil moisture simulated for the western part of the ONWM where agricultural-land cover is prevalent as well as developed lands associated with urbanized areas.

\section{Evapotranspiration (ET)}

Simulated ET was the primary outflow of water from the ONWM area. The 100-year mean ET for water years 1915-2014 was $27.9 \mathrm{in} / \mathrm{yr}$ (table 12A), or about 77 percent of the basinwide mean precipitation rate of $36.1 \mathrm{in} / \mathrm{yr}$. The largest component of ET was $25.9 \mathrm{in} / \mathrm{yr}$ simulated for the soil zone. The remaining components of ET included $1.3 \mathrm{in} / \mathrm{yr}$ for surface water evaporation, $0.06 \mathrm{in} / \mathrm{yr}$ evaporation from impervious surfaces, $0.43 \mathrm{in} / \mathrm{yr}$ evaporation of precipitation intercepted by vegetation, and $0.18 \mathrm{in} / \mathrm{yr}$ sublimation of snow. The basinwide 100-year mean ET for the 32 subbasins varied from a maximum of $30.0 \mathrm{in} / \mathrm{yr}$ in the Polecat Creek subbasin to a minimum of $24.4 \mathrm{in} / \mathrm{yr}$ in the Bear Creek subbasin (table 12A). 


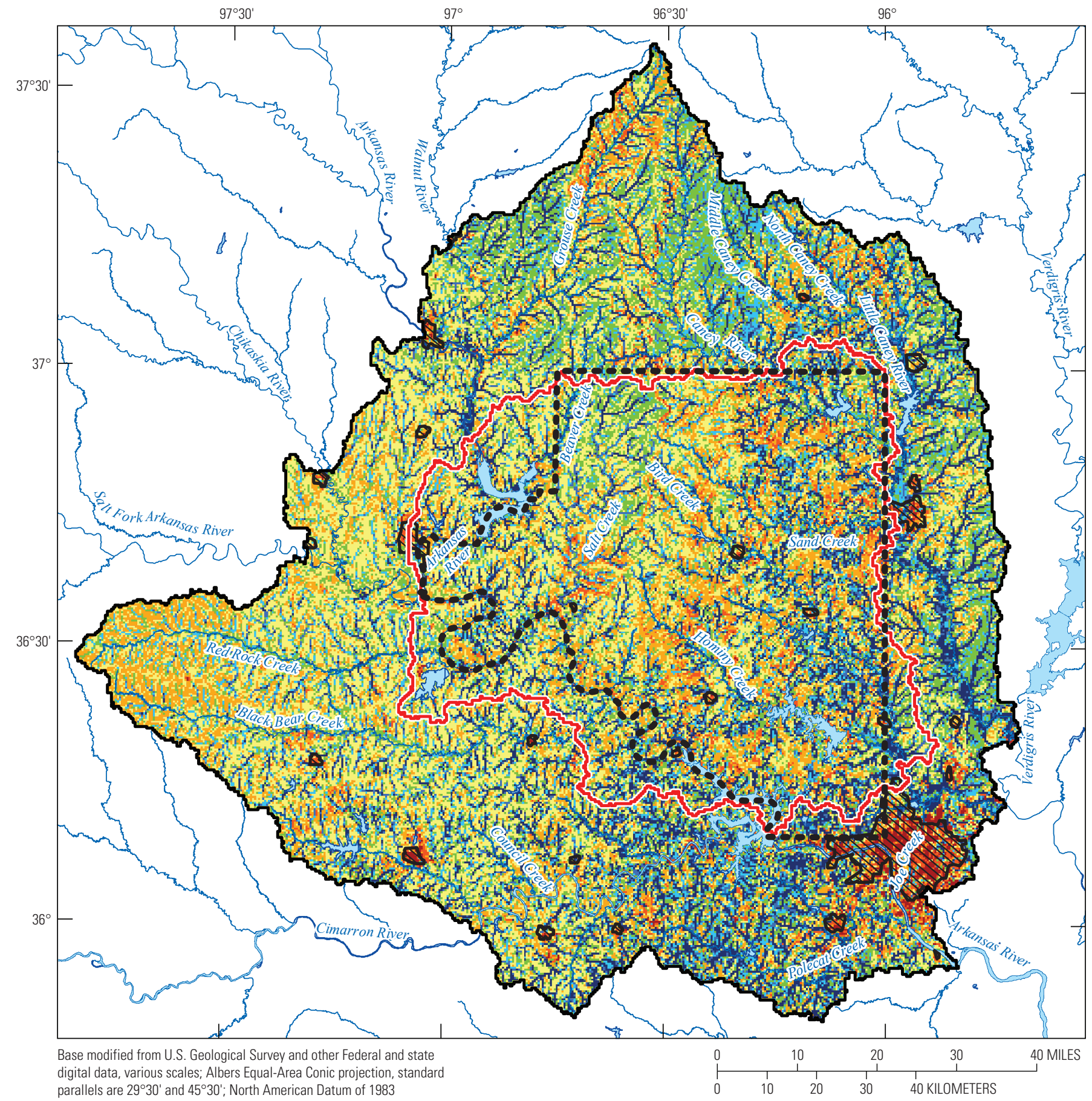

parallels are $29^{\circ} 30^{\prime}$ and $45^{\circ} 30^{\prime}$; North American Datum of 1983

EXPLANATION
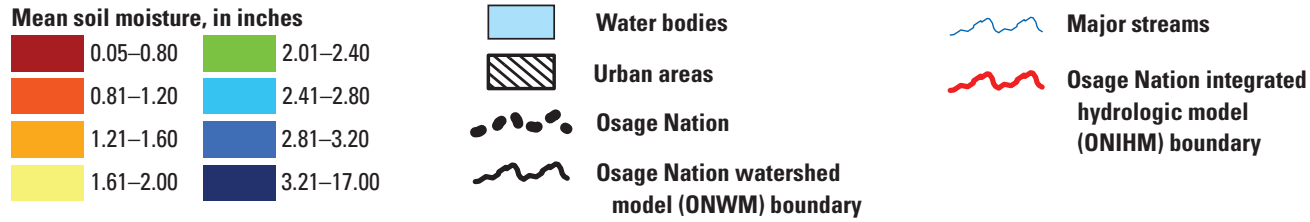

Figure 41. Simulated 100-year mean soil moisture using the 0sage Nation watershed model, water years 1915-2014, 0klahoma and Kansas. 
The mapped results indicated a much higher degree of spatial variability in mean ET compared to the basinwide means for the 32 subbasins (fig. 42, table 12A), with a minimum ET of $1.6 \mathrm{in} / \mathrm{yr}$ and a maximum ET of $48.9 \mathrm{in} / \mathrm{yr}$. High ET of more than $32.1 \mathrm{in} / \mathrm{yr}$ was simulated for HRUs along cascading flow lines and HRUs containing the main stream channels (fig. 42). Intermediate to high ET of 26.1 to $32.0 \mathrm{in} / \mathrm{yr}$ was simulated for parts of the ONWM area having forest cover, gentle slopes, and clayey soils, as well as areas with higher mean precipitation of $37.1 \mathrm{in} / \mathrm{yr}$ and more (fig. 3). Lower mean ET of $24 \mathrm{in} / \mathrm{yr}$ and less was simulated for ridgetops that did not receive inflows from upstream HRUs, urban areas with a substantial percentage of impervious land cover, and areas in the western and northwestern parts of the ONWM where precipitation was lower and the root zone was relatively shallow. In general, the lowest ET was simulated where the soil was the thinnest, the vegetation cover was sparse, and precipitation was the lowest; the highest ET was simulated for stream channels and along cascading flow lines, where the root zone was the deepest, and the availability of water in the root zone was maximized in response to the concentrating of water from cascading flow. Precipitation and PET also had an effect on simulated ET, resulting in lower ET simulated for the western part of the ONWM area where precipitation was lower and for the northern part of the ONWM where PET was lower. On a local scale, simulated ET was less for north-facing slopes compared to south-facing slopes in response to simulated PET (fig. 27). Similar to the results for simulated soil moisture, it should be noted that the ONWM did not account for crop and landscape irrigation, which would likely cause an increase in ET for the western part of the ONWM where agricultural-land cover is prevalent as well as developed lands associated with urbanized areas.

\section{Recharge}

The 100-year mean recharge simulated for water years 1915-2014 was 4.2 in/yr (about 1.9 million acre-ft/yr) for the ONWM area, and this was about 12 percent of the mean precipitation (tables $12 A, B$ ). The simulated mean recharge was the sum of $2.2 \mathrm{in} / \mathrm{yr}$ mean recharge simulated as percolation through the soil zone and 2.0 in/yr mean recharge simulated as seepage of surface water in depression storage used to represent water bodies and major stream channels. The mapped 100-year mean recharge varied from $0.2 \mathrm{in} / \mathrm{yr}$ and less for HRUs in inter-channel areas and drainage divides underlain by low permeability bedrock to more than about 2.0 to $400 \mathrm{in} / \mathrm{yr}$ for HRUs in valleys underlain by highpermeability alluvium (fig. 43). The highest mean recharge rates of about $10-400 \mathrm{in} / \mathrm{yr}$ (about 0.03 to 1.1 inches per day) were simulated for HRUs in the downstream sections of cascading flow paths underlain by high-permeability alluvium. These high 100-year mean recharge rates resulted from the combined recharge of soil zone recharge and seepage from depressions for HRUs in valleys and along stream channels.

The simulated 100-year mean recharge rate for the soil zone (excluding recharge simulated as seepage from depressions) was $2.2 \mathrm{in} / \mathrm{yr}$ for the ONWM area and varied from 4.0 to $145 \mathrm{in} / \mathrm{yr}$ along cascading flow paths to $0-0.5 \mathrm{in} / \mathrm{yr}$ for areas with deeper root zones or steep slopes underlain by low-permeability bedrock. The effects of concentrated surface runoff and interflow along cascading flow paths was an important factor affecting the magnitude and spatial distribution of soil-zone recharge. Soil-zone recharge for inter-channel areas was also dependent on geology because the parameter ssr $2 g w$ rate, controlling the percolation rate from the soil zone to the groundwater reservoir, was defined by the estimated permeability of the underlying rock type, with some adjustment during model calibration. The highest $s s r 2 g w$ rate values were estimated for surficial geology identified as alluvium and terrace (fig. 16), which was mostly along the main stream channels and valley bottoms, and that allowed for relatively high infiltration, recharge, and seepage rates in response to precipitation and the concentration of surface runoff and interflow from upstream HRUs. High $s s r 2 g w$ rate values estimated for the Vamoosa Formation, the Ada Group, the Garber Sandstone, the Wellington Formation, and the Seminole Formation resulted in higher recharge rates of about 1.0 to $5.0 \mathrm{in} / \mathrm{yr}$ for the east-central parts of Osage Nation, and the western and southeastern parts of the ONWM. The results indicated that the spatial distribution of mean recharge was more dependent on the physical properties of the basin and the infiltration of routed surface water along cascading flow paths than on the spatial distribution of mean precipitation in the ONWM area.

\section{Surface Runoff}

Surface runoff simulated by the ONWM is the total overland flow from Hortonian and Dunnian runoff. Hortonian runoff was simulated for each HRU as the fraction of the combined inflows of rainfall, snowmelt, and cascading surface runoff from upstream HRUs exceeding the infiltration capacity and depression storage capacity of pervious land areas and the retention storage capacity of impervious areas defined for each HRU. Dunnian runoff was simulated for each HRU as the fraction of the combined inflow to the soil zone from infiltrating rainfall, snowmelt, and cascading surface runoff and interflow from upstream HRUs exceeding the combined storage capacity of the soil-zone reservoirs for each HRU. The simulated surface runoff was routed along cascading flow paths from upstream to downstream HRUs. All cascading flow paths terminated at HRUs connected to stream segments, where the accumulated surface runoff was added to interflow and groundwater discharge (base flow) routed as cascading flow to stream segments. 


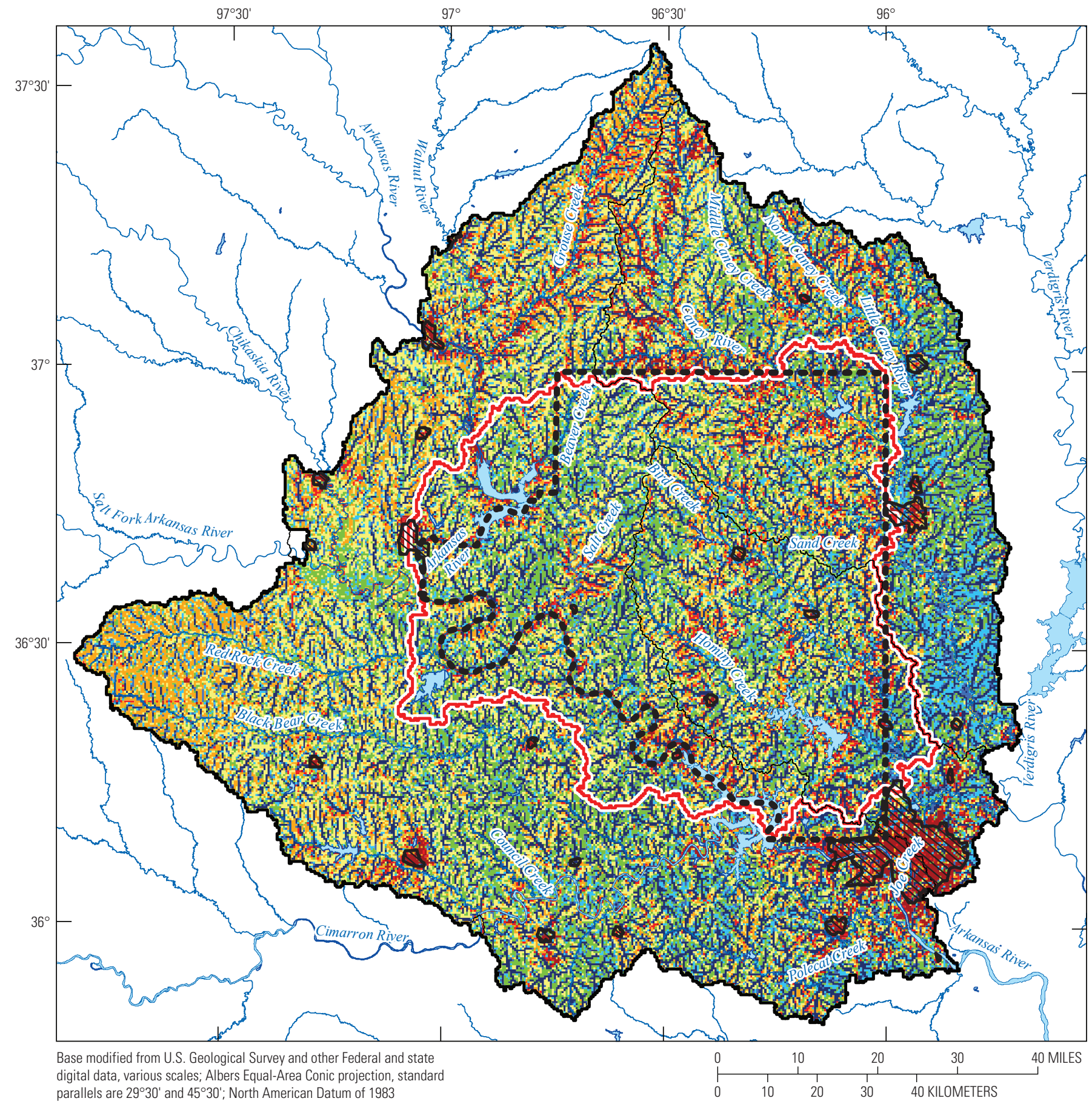

parallels are $29^{\circ} 30^{\prime}$ and $45^{\circ} 30^{\prime}$; North American Datum of 1983

EXPLANATION
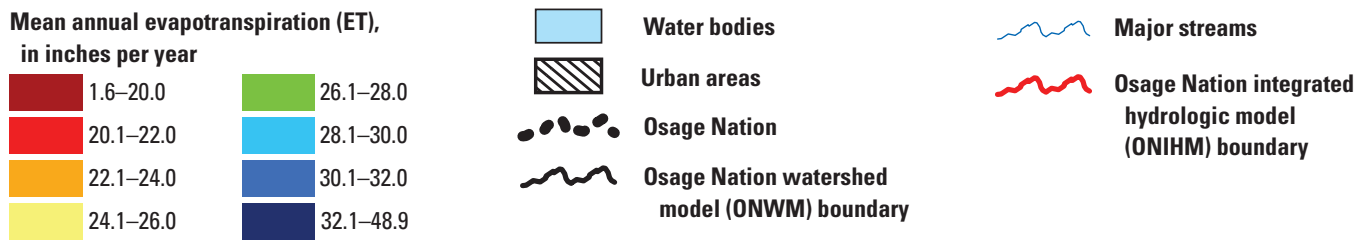

Figure 42. Simulated 100-year mean annual evapotranspiration using the Osage Nation watershed model, water years 1915-2014, Oklahoma and Kansas. 


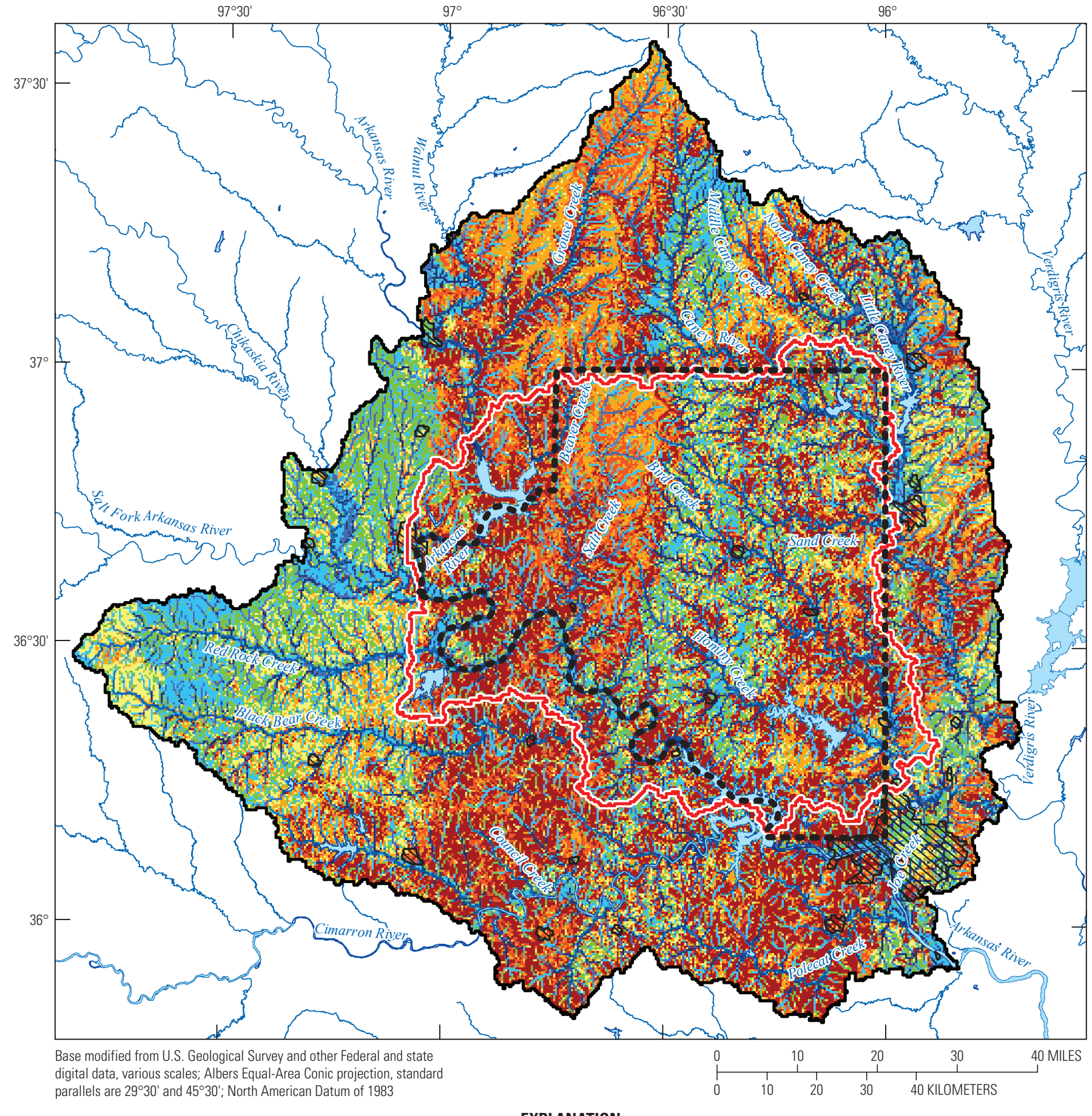

EXPLANATION
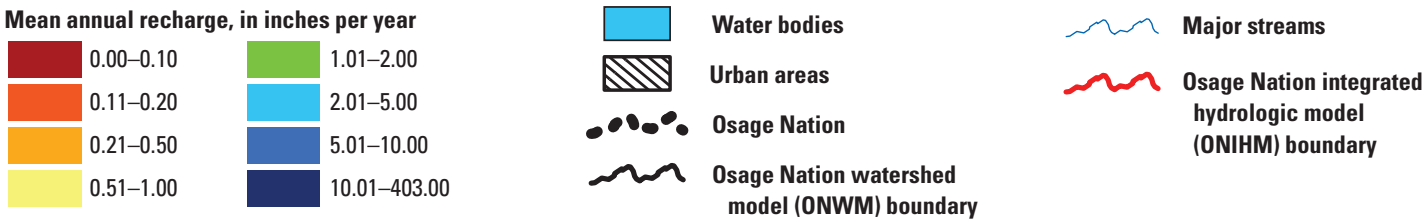

Figure 43. Simulated 100-year mean annual recharge using the Osage Nation watershed model, water years 1915-2014, 0klahoma and Kansas. 
The 100-year mean surface runoff simulated for water years 1915-2014 was $3.5 \mathrm{in} / \mathrm{yr}$ (about 1.5 million acre-ft/yr) for the ONWM area and was about 10 percent of precipitation. The mapped mean surface runoff depth for all HRUs is the mean annual surface runoff depth for the 39.54-acre area of each HRU (fig. 44). The mapped surface runoff depth does not indicate the total water flow from land areas to the stream segments because the base flow contributions from groundwater reservoirs and the interflow contributions from the soil-zone reservoirs are not included. In addition, the mapped surface runoff depth does not indicate the accumulated streamflow routed downstream through the stream segment network.

A mean surface runoff flow rate, in units of cubic feet per second, can be calculated for each HRU by multiplying the surface runoff depth (in inches) by 143,518.8 (the HRU area in square feet divided by 12 inches per foot), and then dividing by $31,557,600$ (the mean number of seconds in one year). Conversely, an equivalent mean annual flow depth in units of inches can be calculated from a flow rate in units of cubic feet per second by multiplying the streamflow by $31,557,600$, which results in the total annual flow volume in cubic feet, then dividing by $143,518.8$.

The mapped results indicated the highest mean annual surface runoff rates of 18.1 to $560 \mathrm{in} / \mathrm{yr}\left(0.08-2.5 \mathrm{ft}^{3} / \mathrm{s}\right)$ were simulated for HRUs that have a high percentage of impervious areas, such as the Tulsa metropolitan area (fig. 44), and for HRUs along the downstream sections of cascadingflow streamlines, especially for longer streamlines in areas of steeper slopes. Moderately high surface runoff rates of 9.1-18 in/yr $\left(0.04-0.08 \mathrm{ft}^{3} / \mathrm{s}\right)$ were simulated for HRUs in inter-channel areas with steeper slopes and thinner soil (figs. 10, 44), areas with higher precipitation rates (figs. 3, 44), and areas with soils having lower field-capacity water contents (figs. 15, 44), such as the eastern part of the Osage Nation and the southern part of the ONWM area. Lower mean annual surface runoff rates of $3.0 \mathrm{in} / \mathrm{yr}\left(0.01 \mathrm{ft}^{3} / \mathrm{s}\right)$ and less were simulated for HRUs in inter-channel areas in the western parts of the Osage Nation and the ONWM area as well as for the eastern part of the ONWM area, where the land-surface slope is lower and the field-capacity water content of soils is higher.

\section{Cascading Flow}

The 100-year mean cascading flow is the total simulated flow from cascading surface runoff, interflow, and groundwater flow (fig. 45). The cascading flow is the accumulated surface runoff and interflow from the HRUs and the accumulated groundwater flow from the groundwater reservoirs along cascading flow paths. The basinwide mean cascading flow for the ONWM area varied from zero to $12,400 \mathrm{in} / \mathrm{yr}\left(56 \mathrm{ft}^{3} / \mathrm{s}\right)$, with flows at most locations between 6.1 and $21 \mathrm{in} / \mathrm{yr}\left(0.03\right.$ and $\left.0.1 \mathrm{ft}^{3} / \mathrm{s}\right)$. The zero flows were simulated at all HRUs (and underlying groundwater reservoirs) connected to stream segments because at these grid locations cascading flow is not simulated; instead the surface runoff, interflow, and groundwater discharge from the HRUs and groundwater reservoirs are simulated as inflows to the stream segments and added to streamflow. The total amount of cascading flow is greater than the combined inflows of surface runoff, interflow, and groundwater discharge (base flow) to stream segments because cascading surface runoff and interflow can contribute to ET simulated for HRUs along the cascading flow path, and cascading groundwater flow can contribute to the groundwater losses simulated for groundwater reservoirs along the cascading flow path.

The larger mean cascading flows of $21 \mathrm{in} / \mathrm{yr}\left(0.1 \mathrm{ft}^{3} / \mathrm{s}\right)$ and greater were simulated along the downstream sections of cascading flow paths. Mean cascading flows of $21 \mathrm{in} / \mathrm{yr}$ and greater were also simulated for HRUs located in urban areas such as Tulsa, Ponca City, Stillwater, and Bartesville; these locations had a high percentage of impervious areas where the simulated surface runoff amounts were also large (figs. 44, 45). Mean cascading flows of $12.1 \mathrm{in} / \mathrm{yr}\left(0.05 \mathrm{ft}^{3} / \mathrm{s}\right)$ and greater tended to be simulated at locations throughout the eastern and northern parts of the ONWM with steep slopes, low soil field capacity, thin soil, high soil hydraulic conductivity, low bedrock permeability, and high precipitation. The lower mean cascading flows, $9 \mathrm{in} / \mathrm{yr}\left(0.04 \mathrm{ft}^{3} / \mathrm{s}\right)$ and less, tended to be simulated at locations in the western parts of the ONWM with gentle slopes, high soil field capacity, low soil hydraulic conductivity, high bedrock permeability, and low precipitation. 


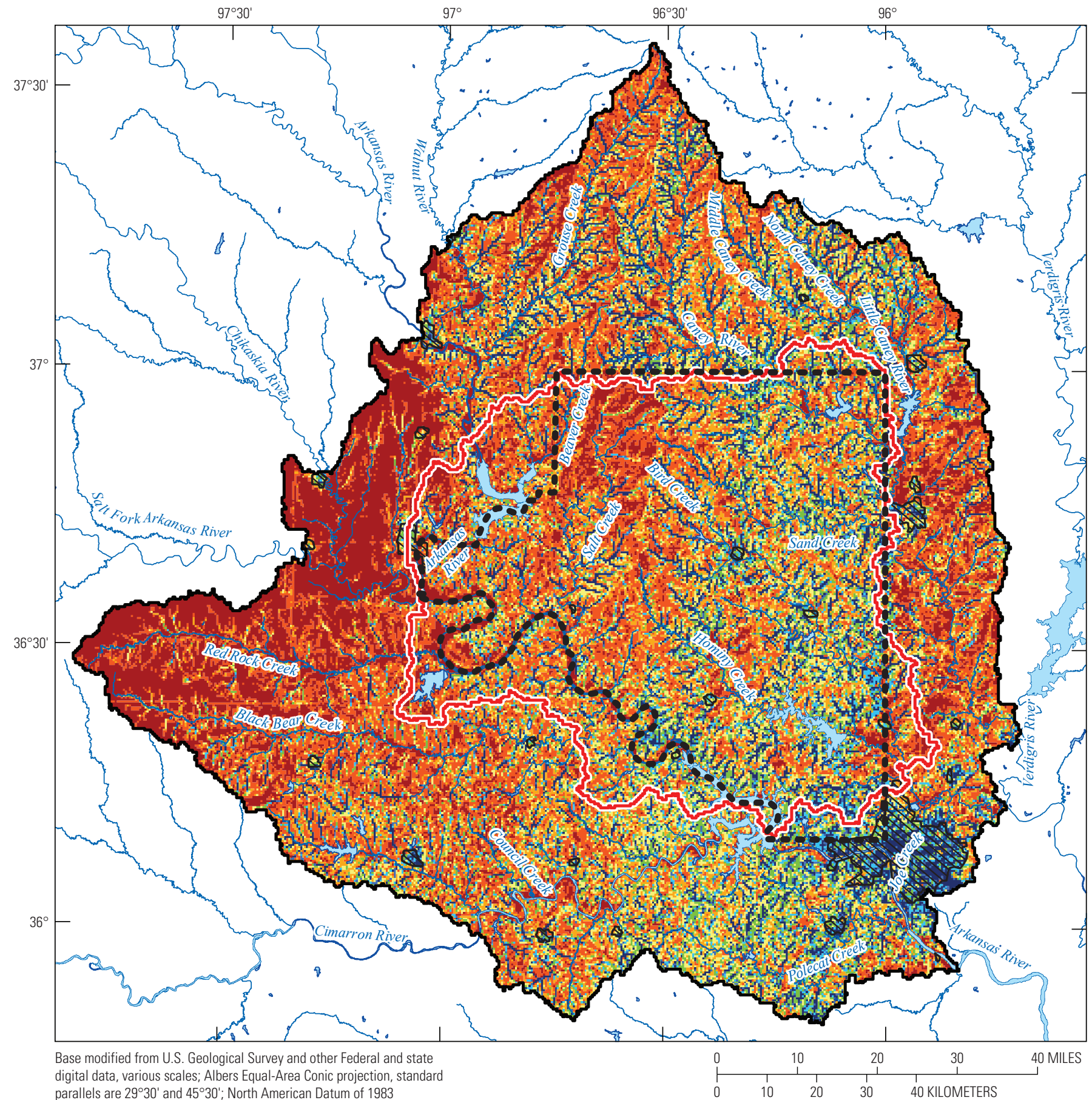

EXPLANATION
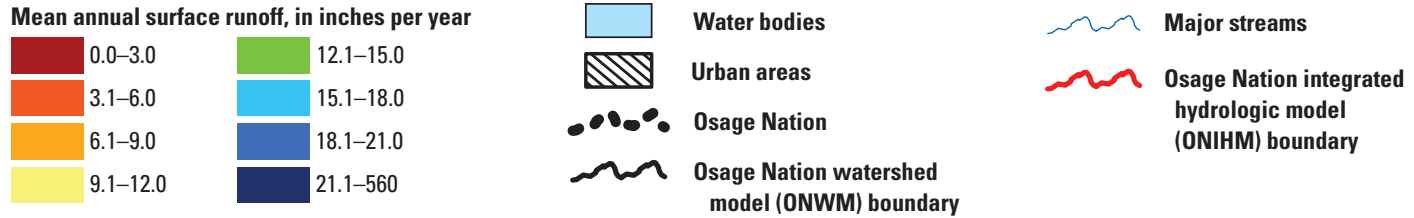

model (ONWM) boundar

Figure 44. Simulated 100-year mean annual surface runoff (Hortonian and Dunnian combined) using the Osage Nation watershed model, water years 1915-2014, 0klahoma and Kansas. 


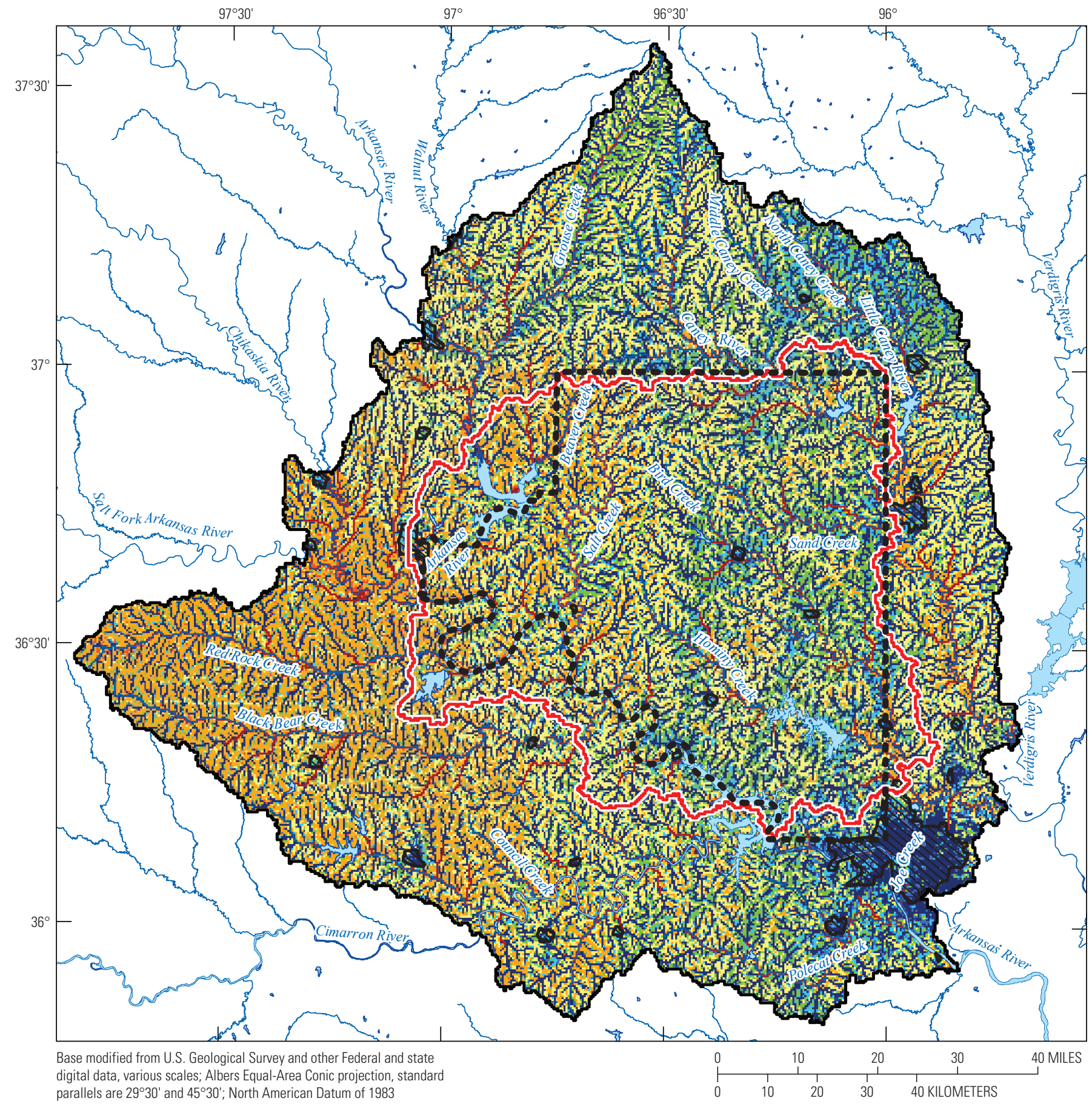

parallels are $29^{\circ} 30^{\prime}$ and $45^{\circ} 30^{\prime}$; North American Datum of 1983

EXPLANATION

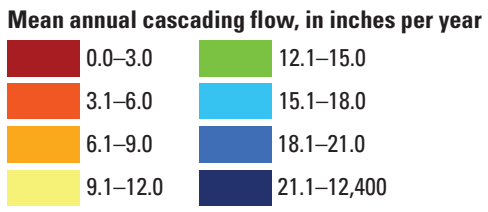

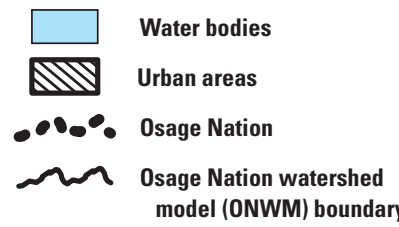

Figure 45. Simulated 100-year mean annual cascading flow (surface runoff, interflow, and groundwater flow combined) using the Osage Nation watershed model, water years 1915-2014, Oklahoma and Kansas. 


\section{Simulated Streamflow, Water Years 1915-2014}

The ONWM simulation results for water years 19152014 included daily mean streamflows for the 7,389 stream segments used to represent the major stream channels in the ONWM area. Daily mean streamflow was simulated using four inflows to the stream segment network: (1) total surface runoff consisting of the combined inflows of Hortonian and Dunnian runoff from HRUs connected to stream segments, (2) total interflow (slow and fast) from HRUs connected to stream segments, (3) base flow from the groundwater reservoirs connected to stream segments, and (4) streamflow from upstream stream segments. For each daily time step, the streamflow at a specified stream segment was not necessarily equivalent to the total accumulated inflows from all upstream HRUs and groundwater reservoirs because of the redistribution of streamflow across stream segments using Muskigum streamflow routing. The redistribution of daily streamflows was needed to better represent the dampening and delay of peak flows caused by channel storage and streamflow lag times greater than 1 day and resulted in an improved overall model calibration for daily mean streamflows.

The simulated streamflow for water years 1915-2014 did not include the river inflows to stream segments at the ONWM boundary from the five surface-water drainages tributary to the Arkansas River surface water subdrainage and upstream from the ONWM area. As such, the simulated streamflow for water years 1915-2014 for the Arkansas River represented only the contribution to streamflow in response to precipitation in the ONWM area. The Caney River and Bird Creek surfacewater drainages do not have boundary inflows from upstream drainages, and therefore, the simulated streamflow for water years 1915-2014 represented the total streamflow in these surface-water drainages.

\section{Mean 100-Year Streamflow}

The simulated 100-year mean streamflow for water years 1915-2014 included a maximum mean streamflow of 2,368 $\mathrm{ft}^{3} / \mathrm{s}$ for the Arkansas River outflow from the Lower Arkansas River subbasin, the largest surface-water outflow from the ONWM area (fig. 46; table 13). Simulated mean streamflows at the outflows from the Caney River and Bird Creek drainages were $1,216 \mathrm{ft}^{3} / \mathrm{s}$ and $747 \mathrm{ft}^{3} / \mathrm{s}$, respectively. The simulated 100-year mean streamflow along the Arkansas River downstream from the confluence with the Red Rock Creek tributary, including the section defining the southwestern boundary of the Osage Nation, was $1,001 \mathrm{ft}^{3} / \mathrm{s}$ or higher (fig. 46). Mean streamflows to the Arkansas River from the main tributaries in the ONWM area, including Salt Creek, Black Bear Creek, Polecat Creek, Salt Creek, and the
Cimarron River, varied from approximately $101 \mathrm{ft}^{3} / \mathrm{s}$ to more than $500 \mathrm{ft}^{3} / \mathrm{s}$. Simulated 100-year mean streamflow for most of the main branch of the Caney River, downstream from its confluence with Sand Creek, varied from approximately $1,001 \mathrm{ft}^{3} / \mathrm{s}$ at the confluence to $1,216 \mathrm{ft}^{3} / \mathrm{s}$ at the mouth of the Caney River. Simulated 100-year mean streamflow for the lowermost section of Bird Creek, downstream from the confluence with Hominy Creek, was approximately $500 \mathrm{ft}^{3} / \mathrm{s}$ at the confluence and increased to $747 \mathrm{ft}^{3} / \mathrm{s}$ at the mouth of Bird Creek. Results for the major tributaries, including Little Caney River, the upper section of Caney River, Sand Creek, the upper section of Bird Creek, and Hominy Creek, indicated mean streamflow rates from about 101 to $500 \mathrm{ft}^{3} / \mathrm{s}$. Results for smaller tributaries, such as North Caney Creek, Council Creek, and Beaver Creek, ranged from less than $10 \mathrm{ft}^{3} / \mathrm{s}$, indicating very low mean flows, to about $100 \mathrm{ft}^{3} / \mathrm{s}$. In most of the headwater sections of streams, mean streamflows were $20 \mathrm{ft}^{3} / \mathrm{s}$ or less. A few of the headwater tributaries, including Upper Grouse Creek, Upper Caney River, and Upper Bird Creek, had mean streamflow discharge rates of about $21-50 \mathrm{ft}^{3} / \mathrm{s}$. The mean inflow rates to the ONIHM subbasin group for the larger tributaries included $365 \mathrm{ft}^{3} / \mathrm{s}$ from the Kaw Lake-Arkansas River subbasin, $292 \mathrm{ft}^{3} / \mathrm{s}$ for the combined inflows from the Cedar Creek and Sycamore Creek-Caney River subbasins, and $250 \mathrm{ft}^{3} / \mathrm{s}$ for the combined inflows from the Lower Black Bear Creek and Lower Camp Creek subbasins (fig. 46, table 13).

\section{Maximum Daily Streamflow}

The simulated daily mean streamflow for water years 1915-2014 included a maximum daily mean flow for the peripheral subbasin group of about $90,590 \mathrm{ft}^{3} / \mathrm{s}$ for the Lower Arkansas River subbasin outflow, about $73,910 \mathrm{ft}^{3} / \mathrm{s}$ for the Lower Caney River subbasin outflow, and about $35,250 \mathrm{ft}^{3} / \mathrm{s}$ for the Lower Bird Creek subbasin outflow (fig. 47; table 13). Maximum daily mean flows of more than $70,000 \mathrm{ft}^{3} / \mathrm{s}$ were simulated for the Arkansas River downstream from the confluence with the Salt Creek tributary along the southwestern boundary of the Osage Nation and for the lower Caney River downstream from the confluence with the Little Caney River tributary (fig. 47). Maximum daily mean flows for Bird Creek upstream from the Hominy Creek tributary were between 15,000 and 20,000 ft $3 / \mathrm{s}$. Maximum daily mean flows were between 20,000 and $40,000 \mathrm{ft}^{3} / \mathrm{s}$ for the main tributaries to the Arkansas and Caney Rivers, between 10,000 and $20,000 \mathrm{ft}^{3} / \mathrm{s}$ for intermediate tributaries, and between 2.9 to $5,000 \mathrm{ft}^{3} / \mathrm{s}$ for the smallest tributaries. Maximum daily mean flows were as high as 5,000 to $10,000 \mathrm{ft}^{3} / \mathrm{s}$ for the headwater sections of many tributaries. 


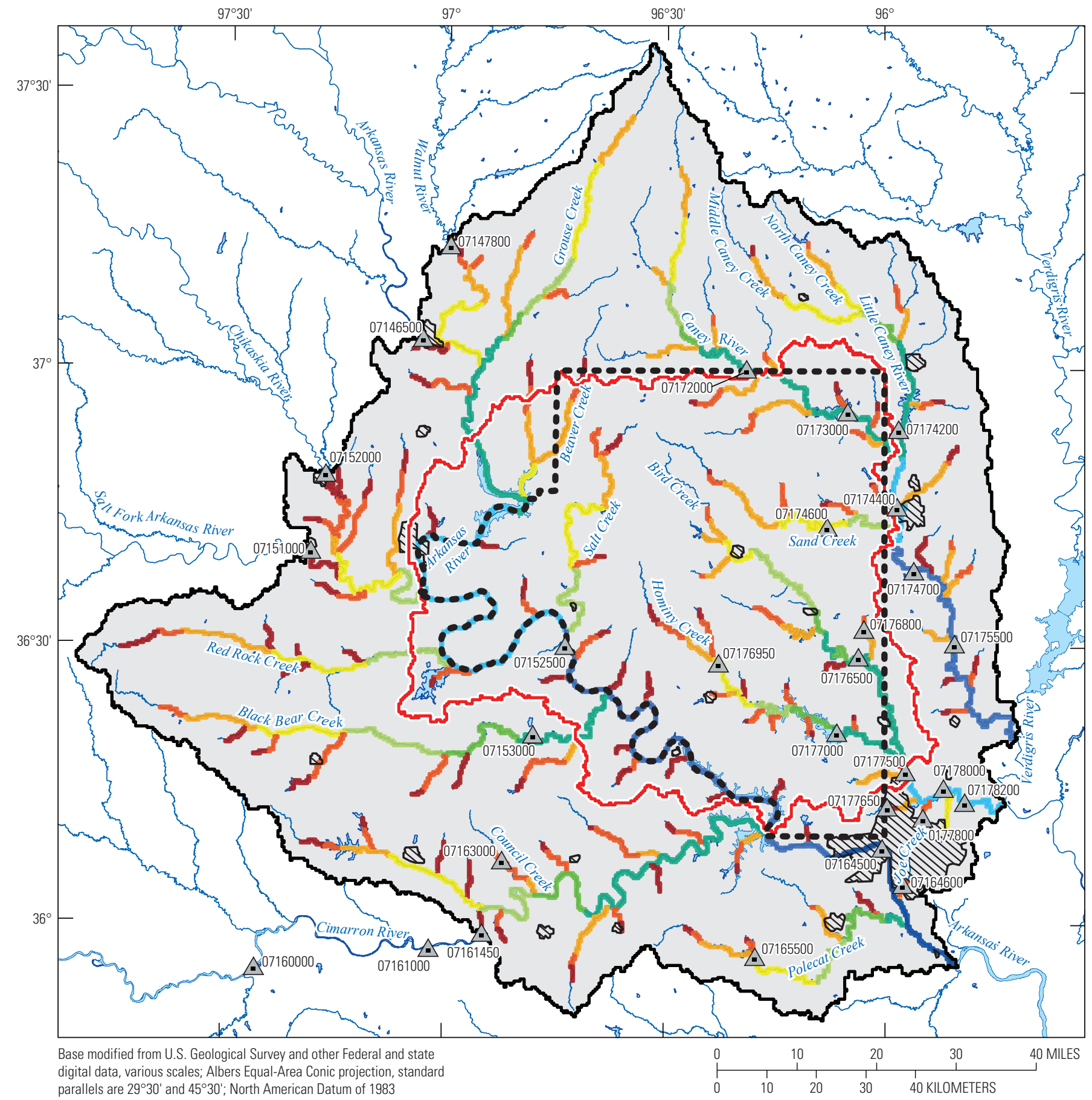

EXPLANATION
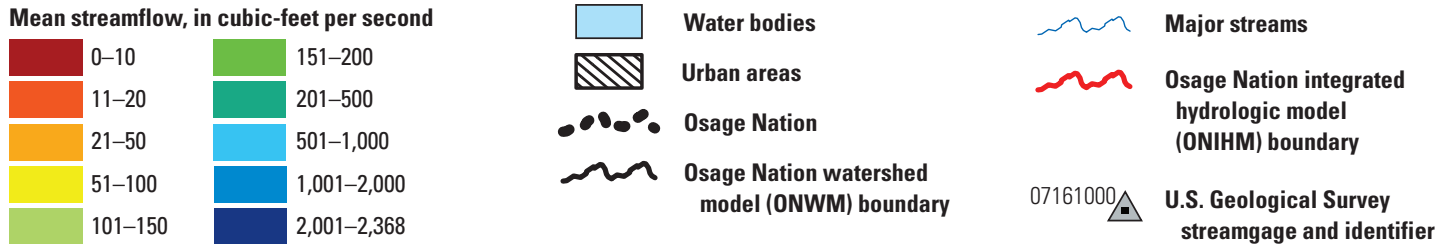

Figure 46. Simulated 100-year mean streamflow using the Osage Nation watershed model, boundary inflows from upstream drainages excluded, water years 1915-2014, Oklahoma and Kansas. 
Table 13. Simulated streamflow for water years 1915-2014, boundary inflows from upstream drainages excluded, using the 0sage Nation watershed model (ONWM), Oklahoma and Kansas.

[ft $\mathrm{ft}^{3} / \mathrm{s}$, cubic feet per second; - , not applicable]

\begin{tabular}{|c|c|c|c|c|c|c|c|c|c|c|}
\hline \multirow{3}{*}{$\begin{array}{l}\text { Subbasin } \\
\text { or subbasin } \\
\text { group code }\end{array}$} & \multirow{3}{*}{$\begin{array}{l}\text { Subbasin or } \\
\text { subbasin group name }\end{array}$} & \multicolumn{3}{|c|}{ Mean for water years 1915-2014 } & \multicolumn{6}{|c|}{ Maximum and minimum streamflow, water years 1915-2014 } \\
\hline & & \multirow{2}{*}{$\begin{array}{l}\text { Inflows from } \\
\text { upstream } \\
\text { drainages } \\
\left(\mathrm{ft}^{3} / \mathrm{s}\right)\end{array}$} & \multirow{2}{*}{$\begin{array}{c}\text { Subbasin } \\
\text { contributing } \\
\text { streamflow } \\
\left(\mathrm{ft}^{3} / \mathrm{s}\right)\end{array}$} & \multirow{2}{*}{$\begin{array}{c}\text { Subbasin } \\
\text { total } \\
\text { outflow } \\
\left(\mathrm{ft}^{3} / \mathbf{s}\right)\end{array}$} & \multicolumn{2}{|c|}{ Annual } & \multicolumn{2}{|c|}{ Monthly } & \multicolumn{2}{|c|}{ Daily } \\
\hline & & & & & $\begin{array}{l}\text { Maximum } \\
\left(\mathrm{ft}^{3} / \mathrm{s}\right)\end{array}$ & $\begin{array}{c}\text { Minimum } \\
\left(\mathrm{ft}^{3} / \mathbf{s}\right)\end{array}$ & $\begin{array}{l}\text { Maximum } \\
\left(\mathrm{ft}^{3} / \mathrm{s}\right)\end{array}$ & $\begin{array}{l}\text { Minimum } \\
\left(\mathrm{ftt}^{3} / \mathrm{s}\right)\end{array}$ & $\begin{array}{l}\text { Maximum } \\
\left(\mathrm{ft}^{3} / \mathrm{s}\right)\end{array}$ & $\begin{array}{c}\text { Minimum } \\
\left(\mathrm{ft}^{3} / \mathbf{s}\right)\end{array}$ \\
\hline CEDAR & Cedar Creek & 0 & 23 & 23 & 64 & 2.2 & 385 & 0.2 & 5,742 & 0.2 \\
\hline SYCAM & Sycamore Creek-Caney River & 0 & 269 & 269 & 719 & 46.3 & 4,299 & 16.3 & 28,620 & 15.0 \\
\hline HBEAV & Headwaters Beaver Creek & 0 & 15 & 15 & 53 & 0.5 & 328 & 0.1 & 4,579 & 0.1 \\
\hline ULBEA & Upper Little Beaver Creek & 0 & 16 & 16 & 67 & 1.0 & 333 & 0.2 & 5,140 & 0.2 \\
\hline KAWLK & Kaw Lake-Arkansas River & 0 & 365 & 365 & 1,051 & 51.9 & 5,832 & 16.7 & 34,880 & 13.9 \\
\hline SALTF & Salt Fork Arkansas River & 0 & 137 & 137 & 587 & 22.3 & 2,849 & 9.8 & 19,020 & 7.8 \\
\hline MREDR & Middle Red Rock Creek & 0 & 120 & 120 & 487 & 13.5 & 3,063 & 5.9 & 22,940 & 4.6 \\
\hline LBEAR & Lower Black Bear Creek & 0 & 221 & 221 & 716 & 36.0 & 4,158 & 15.2 & 18,710 & 12.4 \\
\hline LCAMP & Lower Camp Creek & 0 & 28 & 28 & 96 & 1.6 & 635 & 0.2 & 7,628 & 0.2 \\
\hline- & Upstream subbasin group & 0 & 1,195 & 1,195 & 1,051 & 0.5 & 5,832 & 0.1 & 34,880 & 0.1 \\
\hline MCANE & Middle Caney River & 411 & 53 & 464 & 1,209 & 94.4 & 7,728 & 31.9 & 40,290 & 28.5 \\
\hline BUTLR & Butler Creek & 0 & 15 & 15 & 42 & 2.6 & 235 & 1.3 & 2,614 & 1.1 \\
\hline SANDC & Sand Creek & 0 & 141 & 141 & 352 & 26.4 & 2,047 & 9.6 & 14,380 & 7.3 \\
\hline CBIRD & Charlie Creek-Bird Creek & 156 & 144 & 300 & 736 & 56.3 & 3,921 & 24.6 & 18,530 & 19.4 \\
\hline HOMCK & Rock Creek-Hominy Creek & 0 & 238 & 238 & 610 & 55.3 & 3,028 & 29.5 & 18,350 & 24.2 \\
\hline DELAW & Delaware Creek & 0 & 33 & 33 & 81 & 4.5 & 423 & 1.3 & 3,189 & 1.0 \\
\hline KEYAR & Keystone Lake-Arkansas River & 1,405 & 160 & 1,565 & 4,897 & 330.0 & 28,620 & 143.8 & 84,660 & 126.9 \\
\hline UCANE & Upper Caney River & 292 & 119 & 411 & 1,090 & 85.3 & 6,883 & 28.2 & 40,670 & 25.5 \\
\hline LBEAV & Lower Beaver Creek & 31 & 55 & 87 & 303 & 15.2 & 1,515 & 6.6 & 14,110 & 5.6 \\
\hline BEARC & Bear Creek & 365 & 39 & 404 & 1,162 & 70.3 & 6,502 & 26.4 & 32,910 & 21.4 \\
\hline SALTC & Salt Creek & 0 & 127 & 127 & 377 & 12.6 & 2,454 & 4.0 & 14,310 & 2.8 \\
\hline KAWDM & Kaw Dam-Arkansas River & 491 & 73 & 564 & 1,688 & 114.5 & 9,448 & 47.9 & 41,640 & 39.3 \\
\hline COONC & Coon Creek-Red Rock Creek & 120 & 9 & 129 & 522 & 15.1 & 3,468 & 6.7 & 22,510 & 5.1 \\
\hline SLARK & Sooner Lake-Arkansas River & 957 & 187 & 1,144 & 3,710 & 220.2 & 21,900 & 95.4 & 73,500 & 81.7 \\
\hline CBEAR & Crystal Creek-Black Bear Creek & 250 & 12 & 261 & 828 & 40.4 & 4,840 & 16.2 & 22,180 & 13.3 \\
\hline UBIRD & Upper Bird Creek & 0 & 156 & 156 & 383 & 26.7 & 2,059 & 13.2 & 14,680 & 10.2 \\
\hline ONIHM & $\begin{array}{l}\text { Osage Nation integrated } \\
\text { hydrologic model }\end{array}$ & 1,195 & 1,561 & 2,756 & 4,897 & 2.6 & 28,620 & 1.3 & 84,660 & 1.0 \\
\hline
\end{tabular}


Table 13. Simulated streamflow for water years 1915-2014, boundary inflows from upstream drainages excluded, using the 0sage Nation watershed model (0NWM), Oklahoma and Kansas.-Continued

[ $\mathrm{ft}^{3} / \mathrm{s}$, cubic feet per second; - , not applicable]

\begin{tabular}{|c|c|c|c|c|c|c|c|c|c|c|}
\hline \multirow{3}{*}{$\begin{array}{l}\text { Subbasin } \\
\text { or subbasin } \\
\text { group code }\end{array}$} & \multirow{3}{*}{$\begin{array}{l}\text { Subbasin or } \\
\text { subbasin group name }\end{array}$} & \multicolumn{3}{|c|}{ Mean for water years 1915-2014 } & \multicolumn{6}{|c|}{ Maximum and minimum streamflow, water years 1915-2014 } \\
\hline & & \multirow{2}{*}{$\begin{array}{l}\text { Inflows from } \\
\text { upstream } \\
\text { drainages } \\
\left(\mathrm{ft}^{3} / \mathrm{s}\right)\end{array}$} & \multirow{2}{*}{$\begin{array}{c}\text { Subbasin } \\
\text { contributing } \\
\text { streamflow } \\
\left(\mathrm{ft}^{3} / \mathrm{s}\right)\end{array}$} & \multirow{2}{*}{$\begin{array}{c}\text { Subbasin } \\
\text { total } \\
\text { outflow } \\
\left(\mathrm{ft}^{3} / \mathbf{s}\right)\end{array}$} & \multicolumn{2}{|c|}{ Annual } & \multicolumn{2}{|c|}{ Monthly } & \multicolumn{2}{|c|}{ Daily } \\
\hline & & & & & $\begin{array}{l}\text { Maximum } \\
\qquad\left(\mathrm{ft}^{3} / \mathrm{s}\right)\end{array}$ & $\begin{array}{l}\text { Minimum } \\
\left(\mathrm{ft}^{3} / \mathrm{s}\right)\end{array}$ & $\begin{array}{l}\text { Maximum } \\
\qquad\left(\mathrm{ft}^{3} / \mathrm{s}\right)\end{array}$ & $\begin{array}{l}\text { Minimum } \\
\left(\mathrm{ft}^{3} / \mathrm{s}\right)\end{array}$ & $\begin{array}{l}\text { Maximum } \\
\left(\mathrm{ft}^{3} / \mathrm{s}\right)\end{array}$ & $\begin{array}{c}\text { Minimum } \\
\left(\mathrm{ft}^{3} / \mathrm{s}\right)\end{array}$ \\
\hline LCANE & Lower Caney River & 921 & 294 & 1,216 & 3,152 & 234.2 & 20,210 & 76.3 & 73,910 & 65.8 \\
\hline LBIRD & Lower Bird Creek & 571 & 176 & 747 & 1,760 & 178.2 & 8,957 & 67.8 & 35,250 & 51.9 \\
\hline LWARK & Lower Arkansas River & 2,176 & 192 & 2,368 & 6,752 & 614.9 & 36,380 & 241.6 & 90,590 & 209.0 \\
\hline LICAN & Little Caney River & 0 & 302 & 302 & 844 & 51.1 & 5,203 & 16.1 & 32,710 & 14.1 \\
\hline SKULL & Skull Creek-Cimarron River & 0 & 206 & 206 & 655 & 39.5 & 3,530 & 21.1 & 20,760 & 18.0 \\
\hline KEYCR & Keystone Lake-Cimarron River & 206 & 190 & 396 & 1,218 & 85.1 & 6,291 & 48.0 & 26,850 & 41.2 \\
\hline POLEC & Polecat Creek & 0 & 215 & 215 & 546 & 26.9 & 2,614 & 12.7 & 17,100 & 10.2 \\
\hline - & Peripheral subbasin group & 2,756 & 1,575 & 4,331 & 6,752 & 26.9 & 36,380 & 12.7 & 90,590 & 10.2 \\
\hline ONWM & Osage Nation watershed model & 0 & 4,331 & 4,331 & 6,752 & 0.5 & 36,380 & 0.1 & 90,590 & 0.1 \\
\hline
\end{tabular}




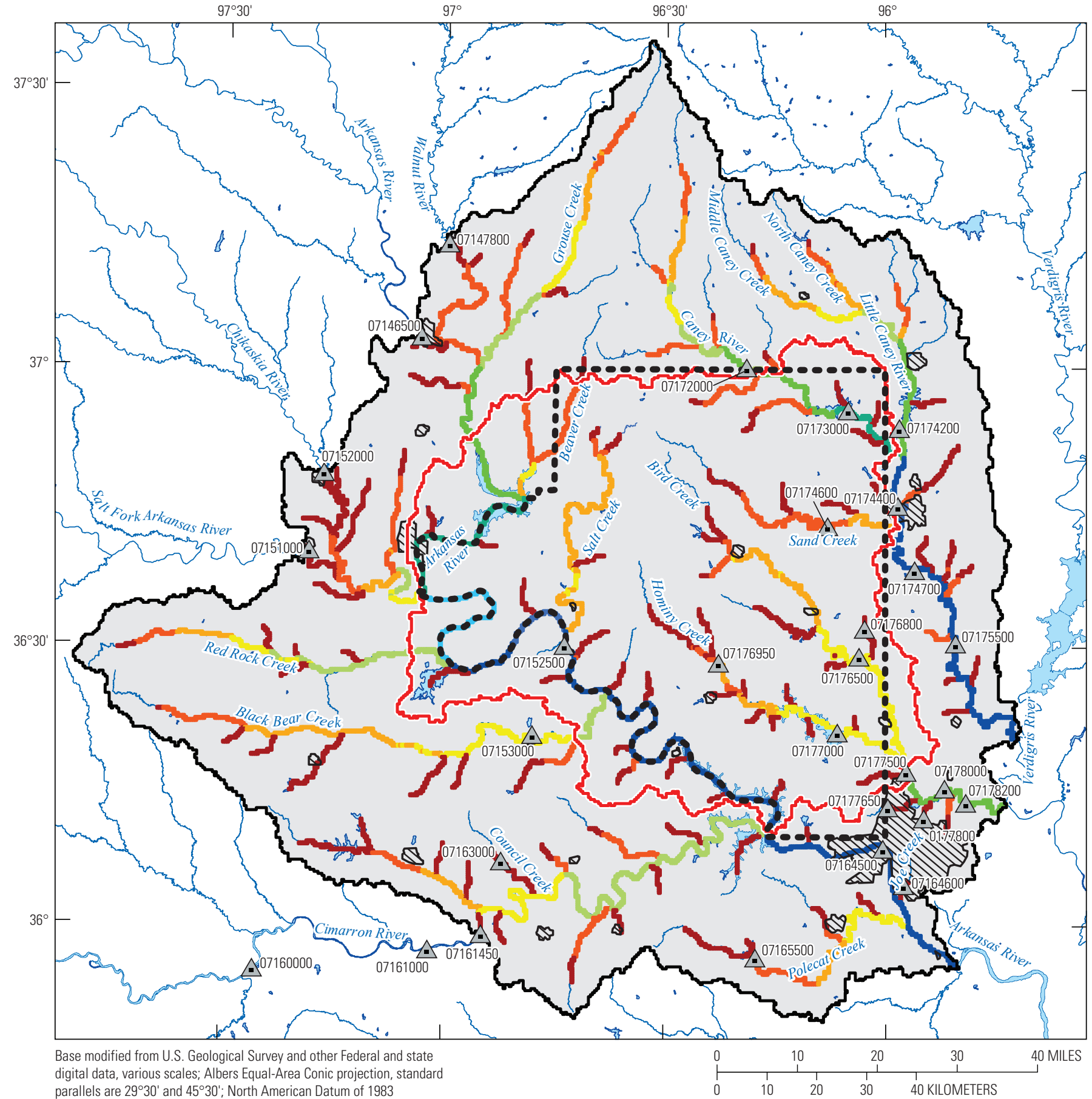

parallels are $29^{\circ} 30^{\prime}$ and $45^{\circ} 30^{\prime}$; North American Datum of 1983

EXPLANATION

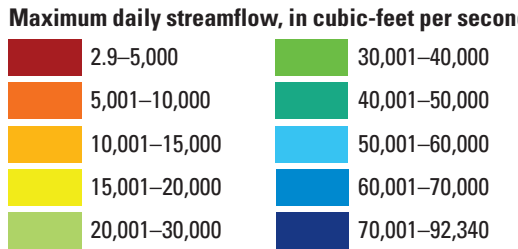

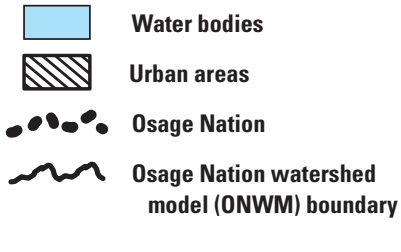

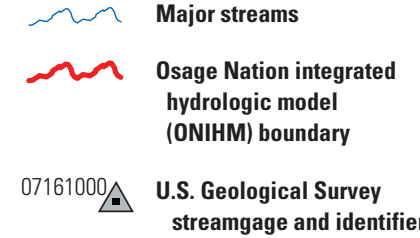

Figure 47. Simulated maximum daily mean streamflow using the 0sage Nation watershed model, boundary inflows excluded, water years 1915-2014, Oklahoma and Kansas. 


\section{Minimum Daily Streamflow}

The simulated minimum streamflows for water years 1915-2014 included daily mean flow rates that were more than three orders of magnitude less than maximum daily mean flow rates for most of the ONWM area (figs. 47, 48). Very low streamflows of less than 0.1 to $0.2 \mathrm{ft}^{3} / \mathrm{s}$ were considered to effectively represent a dry stream channel based on an approximate level of model precision likely associated with streamflow simulated by the ONWM. Results indicated that low daily mean flows of 0.1 to $0.2 \mathrm{ft}^{3} / \mathrm{s}$ and less were simulated for many of the headwater sections of smaller tributaries, such as North Caney Creek, upper Hominy Creek, and Sand Creek, indicating ephemeral or intermittent conditions for these locations. Simulated minimum daily mean flows for the three ONWM outflows included $65.8 \mathrm{ft}^{3} / \mathrm{s}$ for the Lower Caney River subbasin outflow, $51.9 \mathrm{ft}^{3} / \mathrm{s}$ for Lower Bird Creek subbasin outflow, and $209 \mathrm{ft}^{3} / \mathrm{s}$ for the Lower Arkansas River subbasin outflow (fig. 47; table 13). Minimum monthly mean and daily mean inflows from upstream subbasins to the ONIHM subbasins were similar (table 13), with larger minimum daily mean inflows of $13.9 \mathrm{ft}^{3} / \mathrm{s}$ from Kaw Lake-Arkansas River subbasin, $15.0 \mathrm{ft}^{3} / \mathrm{s}$ from the Sycamore Creek-Caney River subbasin, and $12.4 \mathrm{ft}^{3} / \mathrm{s}$ from the Lower Black Bear Creek subbasin. Smaller minimum daily mean inflows of $0.2 \mathrm{ft}^{3} / \mathrm{s}$ were simulated for the Cedar Creek, Upper Little Beaver Creek, and Lower Camp Creek subbasins, and $0.1 \mathrm{ft}^{3} / \mathrm{s}$ was simulated for the Headwaters Beaver Creek subbasin. The largest minimum daily mean outflow from the ONIHM subbasin group was $127 \mathrm{ft}^{3} / \mathrm{s}$ for the Keystone LakeArkansas River subbasin. Minimum daily mean outflows from the other subbasins in the ONIHM subbasin group included $28.5 \mathrm{ft}^{3} / \mathrm{s}$ for Middle Caney River, $7.3 \mathrm{ft}^{3} / \mathrm{s}$ for Sand Creek,
$1.1 \mathrm{ft}^{3} / \mathrm{s}$ for Butler Creek, $19.4 \mathrm{ft}^{3} / \mathrm{s}$ for Charlie Creek-Bird Creek, $24.2 \mathrm{ft}^{3} / \mathrm{s}$ for Rock Creek-Hominy Creek, and $1.0 \mathrm{ft}^{3} / \mathrm{s}$ for Delaware Creek.

The mean, maximum, and minimum daily mean streamflows simulated for water years 1915-2014 for all 7,389 stream segments were plotted against the upstream contributing drainage area for each stream segment (fig. 49). The plot shows strong correlations between mean and maximum streamflows and the upstream contributing area, with $R^{2}$ values of 0.98 for mean flows and 0.95 for maximum daily mean flows. Results for minimum daily mean streamflows indicated a moderate correlation to upstream contributing drainage area, with an $R^{2}$ of 0.84 . Stream segments with contributing areas of $1,000 \mathrm{mi}^{2}$ and greater had simulated mean streamflows of about $400 \mathrm{ft}^{3} / \mathrm{s}$ and higher, maximum daily mean flows of about $30,000 \mathrm{ft}^{3} / \mathrm{s}$ and higher, and minimum daily mean flows of about $20 \mathrm{ft}^{3} / \mathrm{s}$ and higher, which is an approximate range of three orders of magnitude between maximum and minimum daily mean streamflows simulated by the ONWM.

Stream segments with contributing areas of 1 to $10 \mathrm{mi}^{2}$ were characterized by mean flows of about 0.8 to $7 \mathrm{ft}^{3} / \mathrm{s}$, maximum daily mean flows of about 70 to $1,200 \mathrm{ft}^{3} / \mathrm{s}$, and minimum daily mean flows of about $0.4 \mathrm{ft}^{3} / \mathrm{s}$ and less. Many stream segments with upstream areas of $100 \mathrm{mi}^{2}$ and smaller had minimum daily mean flows of $0.1 \mathrm{ft}^{3} / \mathrm{s}$ and less. In general, daily results for most of the smaller, headwater stream segments indicated very low streamflows of less than $0.2 \mathrm{ft}^{3} / \mathrm{s}$ during dry periods and were considered representative of ephemeral to intermittent conditions. Maximum and minimum daily mean streamflows for many of the stream segments with contributing areas of $100 \mathrm{mi}^{2}$ and less differed by a range of approximately four orders of magnitude. 


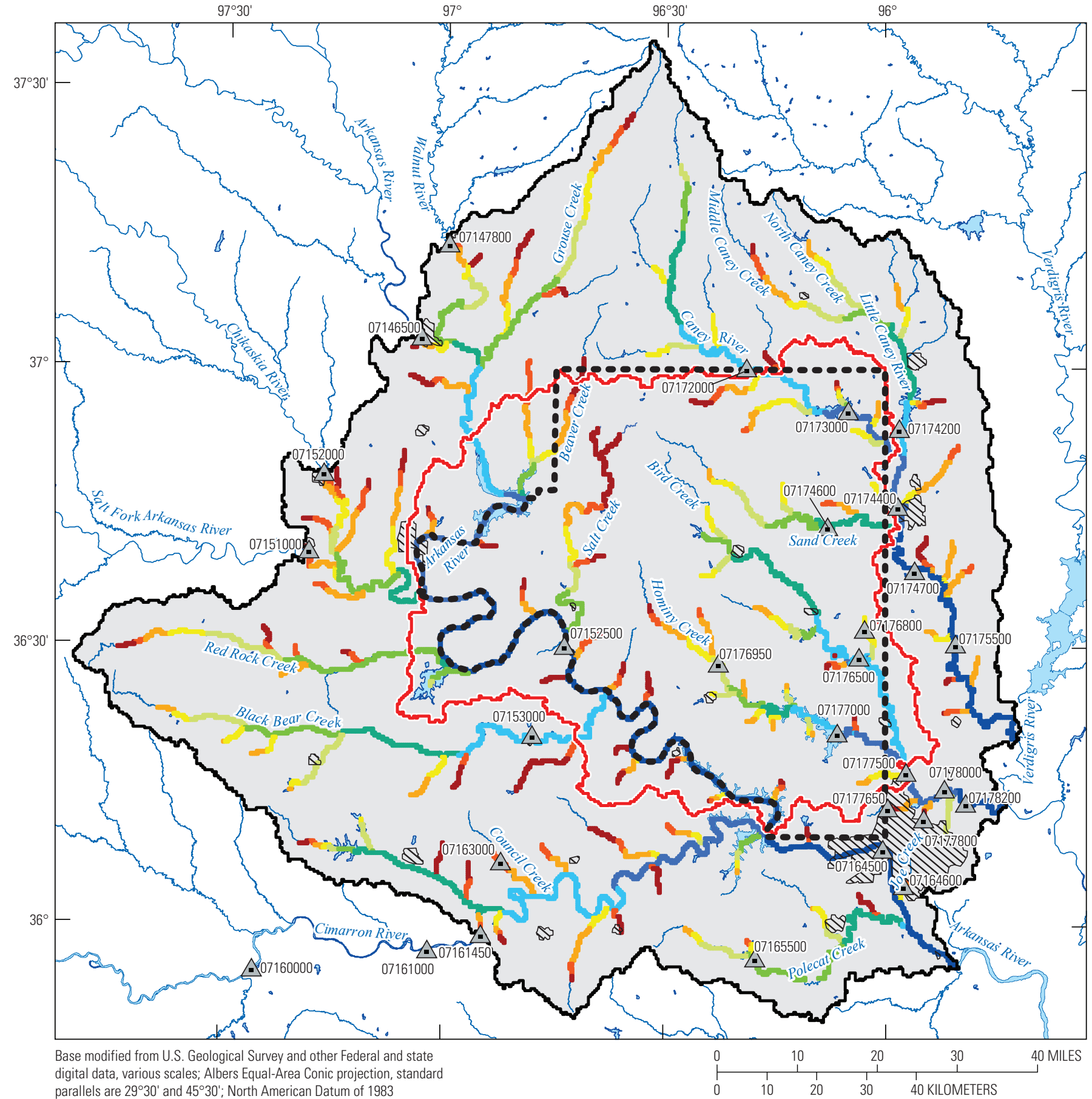

(t) Equal-Area Conic projection, standard

EXPLANATION

\begin{tabular}{|c|l|}
\hline Minimum daily streamflow, in cubic-feet per seco \\
\hline $0.00-0.10$ & $2.01-5.00$ \\
\hline $0.11-0.20$ & $5.01-10.00$ \\
$0.21-0.50$ & $10.01-20.00$ \\
$0.51-1.00$ & $20.01-50.00$ \\
$1.01-2.00$ & $50.01-209.00$ \\
\hline
\end{tabular}
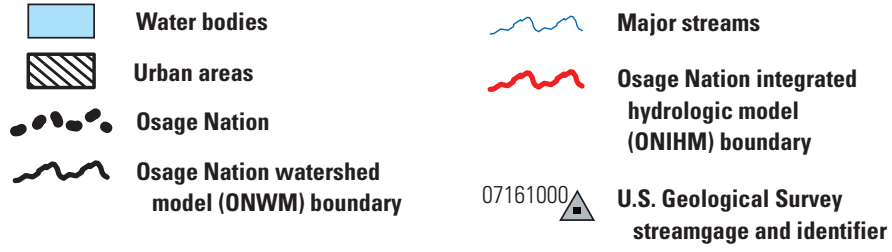

Figure 48. Simulated minimum daily mean streamflow using the Osage Nation watershed model, boundary inflows excluded, water years 1915-2014, Oklahoma and Kansas. 


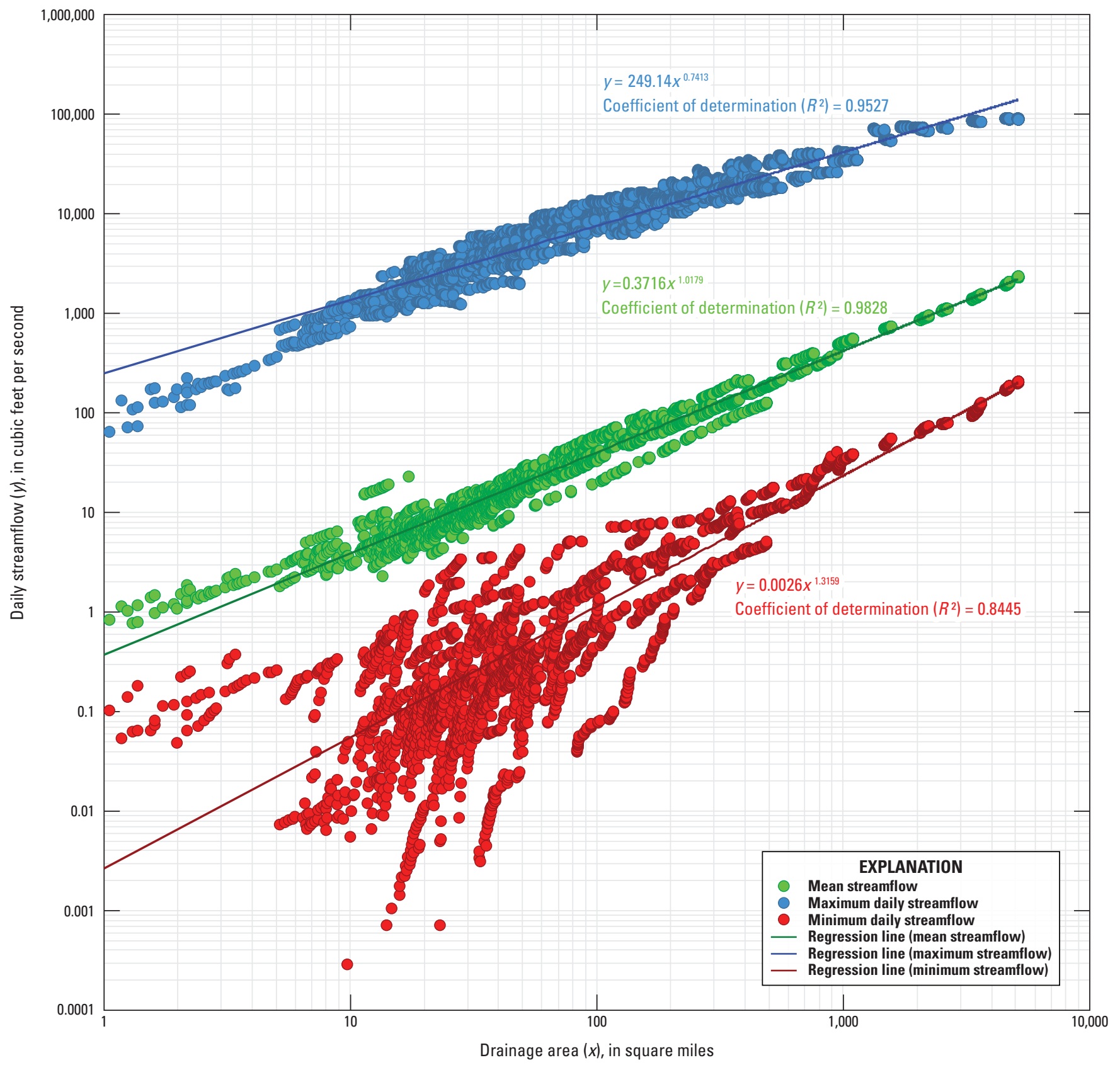

Figure 49. Simulated mean, maximum, and minimum daily streamflow, boundary inflows excluded, verus contributind drainage areas for stream segments in the Osage Nation watershed model, water years 1915-2014, Oklahoma and Kansas. 


\section{Simulated Streamflow, Water Years 1938-2014}

A primary objective of the ONWM was to simulate the inflow boundary conditions for the ONIHM, including the simulated streamflow from the ONWM contributing areas combined with the river inflows at the ONWM boundary. Simulated mean streamflow for the 77-year period of water years 1938-2014 was analyzed using a comparison of simulations run with and without the daily river inflows at the ONWM boundary from the five surface-water drainages upstream from the ONWM and tributary to the Arkansas River surface-water subdrainage; (1) the Arkansas River, (2) the Cimarron River, (3) the Walnut River, (4) the Chikaskia River, and (5) the Salt Fork of the Arkansas River. The increases in simulated streamflow in response to the inclusion of the five river inflows affected only the streamflows in stream segments downstream of the inflows in the Arkansas River surface water subdrainage (figs. 1, 2). Streamflows for the Caney River and Bird Creek surface-water drainage basins were not affected by river inflows from upstream drainages. The inclusion of the river inflows was needed to simulate the total streamflows in the Arkansas River surface water subdrainage and to simulate the total inflow boundary condition for the ONIHM area. The additional water supplied by the river inflows was added to the simulated runoff simulated by the ONWM and routed through the network of stream segments using the Muskingum routing method. The additional inflows affected only the streamflow component of the simulated water budget; simulation results for the HRUs and active groundwater reservoirs in the Arkansas River surface-water subdrainage were not affected by the river inflows.

The five river inflows contributed a total mean streamflow of $6,106 \mathrm{ft}^{3} / \mathrm{s}$ to the ONWM area and included $977 \mathrm{ft}^{3} / \mathrm{s}$ from the Walnut River, 2,097 $\mathrm{ft}^{3} / \mathrm{s}$ from the Arkansas River, $612 \mathrm{ft}^{3} / \mathrm{s}$ from the Chikaskia River, $890 \mathrm{ft}^{3} / \mathrm{s}$ from the Salt Fork of the Arkansas River, and 1,530 $\mathrm{ft}^{3} / \mathrm{s}$ from the Cimarron River. The combined streamflows from the Walnut and Arkansas Rivers contributed a mean inflow of 3,075 ft $\mathrm{ft}^{3} / \mathrm{s}$ to the Kaw Lake-Arkansas River subbasin (table 14A). The combined streamflows from the Chikaskia River and the Salt Fork of the Arkansas River contributed a mean inflow of 1,502 $\mathrm{ft}^{3} / \mathrm{s}$ to the Salt Fork Arkansas River subbasin. The inflows to the Kaw Lake-Arkansas River subbasin and the Salt Fork Arkansas River subbasin resulted in a combined inflow of $4,576 \mathrm{ft}^{3} / \mathrm{s}$ to the ONIHM subbasin group. Streamflow from the Cimarron River provided a mean inflow of $1,530 \mathrm{ft}^{3} / \mathrm{s}$ to the Skull Creek-Cimarron River subbasin and contributed only to the total streamflow of the peripheral subbasin group.

The simulated 77-year mean streamflow from the ONWM area for water years 1938-2014 was about $10,570 \mathrm{ft}^{3} / \mathrm{s}$ with the river inflows included (table 14A), which was more than double the 77-year mean streamflow of $4,468 \mathrm{ft}^{3} / \mathrm{s}$ simulated from the ONWM area with the river inflows excluded (table 14B). The inclusion of river inflows almost tripled the mean streamflow simulated for the ONIHM subbasin group, from $2,843 \mathrm{ft}^{3} / \mathrm{s}$ without the inflows to $7,420 \mathrm{ft}^{3} / \mathrm{s}$ with the inflows included, and also resulted in almost a five-fold increase in mean streamflow from the upstream subbasin group, from $1,227 \mathrm{ft}^{3} / \mathrm{s}$ without the inflows to $5,804 \mathrm{ft}^{3} / \mathrm{s}$ with the inflows included.

The river inflows did not affect the contributions to total streamflow from the land areas of the subbasins in the ONWM area (table 14C). The Kaw Lake-Arkansas River subbasin had the largest contribution to streamflow compared to the other subbasins, with a mean streamflow of $373 \mathrm{ft}^{3} / \mathrm{s}$ contributed to the total mean streamflow of $3,447 \mathrm{ft}^{3} / \mathrm{s}$ simulated with the river inflows included. The Coon Creek-Red Rock Creek subbasin had the smallest contribution of only $9 \mathrm{ft}^{3} / \mathrm{s}$ to the total mean streamflow of $135 \mathrm{ft}^{3} / \mathrm{s}$ simulated for the subbasin. Simulated mean streamflow of $1,625 \mathrm{ft}^{3} / \mathrm{s}$ from the peripheral subbasin group was the largest contribution from the ONWM area to the total mean streamflow and was only slightly more than the mean streamflow of $1,616 \mathrm{ft}^{3} / \mathrm{s}$ contributed by the ONIHM subbasin group. Mean streamflows simulated for the 77-year period were slightly greater for most of the subbasins compared to the mean streamflows simulated for water years 1915-2014 (tables 13, 14B), with the greatest increase of $13 \mathrm{ft}^{3} / \mathrm{s}$ simulated for the Lower Caney River subbasin. The ONIHM subbasin group had the largest increase in mean streamflow of $57 \mathrm{ft}^{3} / \mathrm{s}$ for the 77 -year simulation period compared to the 100-year period. Three subbasins in the upstream subbasin group and two subbasins in the ONIHM subbasin group had negligible differences in mean streamflow of $0.5 \mathrm{ft}^{3} / \mathrm{s}$ or less. The total mean streamflow simulated for the ONWM area for water years 1938-2014 was $137 \mathrm{ft}^{3} / \mathrm{s}$ more than the mean streamflow simulated for water years 19152014 (tables 13, 14B).

The inclusion of the river inflows affected the simulated streamflows for 10 subbasins in the Arkansas River surface water subdrainage, resulting in increases in the mean, maximum, and minimum streamflows for these subbasins (table 14C). The largest increase in maximum annual mean streamflow for the ONIHM subbasin group was about $13,090 \mathrm{ft}^{3} / \mathrm{s}$ for the Sooner Lake-Arkansas River subbasin, and the largest increase for the ONWM area was about $18,570 \mathrm{ft}^{3} / \mathrm{s}$ for the Lower Arkansas River subbasin. Increases in minimum annual mean streamflow for subbasins affected by the river inflows varied from $169 \mathrm{ft}^{3} / \mathrm{s}$ for the Salt Fork Arkansas River subbasin to $1,090 \mathrm{ft}^{3} / \mathrm{s}$ for the Lower Arkansas River subbasin. Maximum monthly mean streamflows increased from a minimum of about $20,100 \mathrm{ft}^{3} / \mathrm{s}$ to a maximum of about $58,610 \mathrm{ft}^{3} / \mathrm{s}$ for the 10 subbasins affected by the boundary inflows. A maximum daily mean streamflow of about 191,700 ft $\mathrm{ft}^{3} / \mathrm{s}$ was simulated for the Lower Arkansas River subbasin with the river inflows included, compared to a maximum daily mean streamflow of about $90,590 \mathrm{ft}^{3} / \mathrm{s}$ simulated with the river inflows excluded. 
Table 14A. Simulated streamflow for water years 1938-2014, boundary inflows from upstream drainages included, Osage Nation watershed model mean (ONWM), Oklahoma and Kansas.

[fts $/ \mathrm{s}$, cubic feet per second; - , not applicable]

\begin{tabular}{|c|c|c|c|c|c|c|c|c|c|c|}
\hline \multirow{3}{*}{$\begin{array}{c}\text { Subbasin } \\
\text { or subbasin } \\
\text { group code }\end{array}$} & \multirow{3}{*}{$\begin{array}{c}\text { Subbasin or } \\
\text { subbasin group name }\end{array}$} & \multicolumn{3}{|c|}{ Mean streamflow for water years 1938-2014 } & \multicolumn{6}{|c|}{ Maximum and minimum subbasin outflow (streamflow) water years 1938-2014 } \\
\hline & & \multirow{2}{*}{$\begin{array}{l}\text { Inflows from } \\
\text { upstream } \\
\text { drainages } \\
\left(\mathrm{ft}^{3} / \mathbf{s}\right)\end{array}$} & \multirow{2}{*}{$\begin{array}{c}\text { Subbasin } \\
\text { contributing } \\
\text { streamflow } \\
\left(\mathrm{ft}^{3} / \mathrm{s}\right)\end{array}$} & \multirow{2}{*}{$\begin{array}{c}\text { Subbasin } \\
\text { total outflow } \\
\left(\mathrm{ft}^{3} / \mathrm{s}\right)\end{array}$} & \multicolumn{2}{|c|}{ Annual } & \multicolumn{2}{|c|}{ Monthly } & \multicolumn{2}{|c|}{ Daily } \\
\hline & & & & & $\begin{array}{l}\text { Maximum } \\
\left(\mathrm{ft}^{3} / \mathbf{s}\right)\end{array}$ & $\begin{array}{l}\text { Minimum } \\
\left(\mathrm{ft}^{3} / \mathbf{s}\right)\end{array}$ & $\begin{array}{l}\text { Maximum } \\
\quad\left(\mathrm{ft}^{3} / \mathrm{s}\right)\end{array}$ & $\begin{array}{l}\text { Minimum } \\
\left(\mathbf{f t} \mathbf{t}^{3} / \mathbf{s}\right)\end{array}$ & $\begin{array}{l}\text { Maximum } \\
\quad\left(\mathrm{ft}^{3} / \mathrm{s}\right)\end{array}$ & $\begin{array}{l}\text { Minimum } \\
\left(\mathrm{ft}^{3} / \mathrm{s}\right)\end{array}$ \\
\hline CEDAR & Cedar Creek & 0 & 23 & 23 & 64 & 2.2 & 385 & 0.2 & 5,742 & 0.2 \\
\hline SYCAM & Sycamore Creek-Caney River & 0 & 274 & 274 & 719 & 46.3 & 4,299 & 16.3 & 28,620 & 15.0 \\
\hline HBEAV & Headwaters Beaver Creek & 0 & 15 & 15 & 53 & 0.5 & 328 & 0.1 & 4,579 & 0.1 \\
\hline ULBEA & Upper Little Beaver Creek & 0 & 17 & 17 & 67 & 1.0 & 333 & 0.2 & 5,140 & 0.2 \\
\hline KAWLK & Kaw Lake-Arkansas River & 3,075 & 373 & 3,447 & 8,809 & 559.5 & 31,030 & 63.1 & 126,500 & 45.6 \\
\hline SALTF & Salt Fork Arkansas River & 1,502 & 141 & 1,643 & 6,319 & 191.6 & 22,950 & 12.2 & 81,330 & 9.0 \\
\hline MREDR & Middle Red Rock Creek & 0 & 126 & 126 & 487 & 13.5 & 3,063 & 5.9 & 22,940 & 4.6 \\
\hline LBEAR & Lower Black Bear Creek & 0 & 228 & 228 & 716 & 36.0 & 4,158 & 15.2 & 18,710 & 12.4 \\
\hline LCAMP & Lower Camp Creek & 0 & 30 & 30 & 96 & 1.6 & 635 & 0.2 & 7,628 & 0.2 \\
\hline- & Upstream subbasin group & 4,576 & 1,227 & 5,804 & 8,809 & 0.5 & 31,030 & 0.1 & 126,500 & 0.1 \\
\hline MCANE & Middle Caney River & 421 & 55 & 476 & 1,209 & 94.4 & 7,728 & 32.2 & 40,290 & 28.5 \\
\hline BUTLR & Butler Creek & 0 & 15 & 15 & 42 & 2.6 & 235 & 1.3 & 2,614 & 1.1 \\
\hline SANDC & Sand Creek & 0 & 147 & 147 & 352 & 27.5 & 2,047 & 9.6 & 14,380 & 7.3 \\
\hline CBIRD & Charlie Creek-Bird Creek & 162 & 151 & 313 & 736 & 65.0 & 3,921 & 24.6 & 18,530 & 19.4 \\
\hline HOMCK & Rock Creek-Hominy Creek & 0 & 246 & 246 & 610 & 55.3 & 3,028 & 29.5 & 18,350 & 24.2 \\
\hline DELAW & Delaware Creek & 0 & 34 & 34 & 81 & 5.4 & 423 & 1.3 & 3,189 & 1.0 \\
\hline KEYAR & Keystone Lake-Arkansas River & 6,025 & 164 & 6,190 & 17,960 & 1,052 & 62,040 & 202.5 & 147,600 & 158.0 \\
\hline UCANE & Upper Caney River & 298 & 124 & 421 & 1,090 & 85.3 & 6,883 & 28.2 & 40,670 & 25.7 \\
\hline LBEAV & Lower Beaver Creek & 32 & 57 & 89 & 303 & 15.2 & 1,515 & 6.6 & 14,110 & 5.8 \\
\hline BEARC & Bear Creek & 3,447 & 40 & 3,487 & 8,878 & 575.9 & 31,080 & 78.6 & 119,600 & 55.5 \\
\hline SALTC & Salt Creek & 0 & 133 & 133 & 377 & 12.6 & 2,454 & 4.0 & 14,310 & 2.8 \\
\hline KAWDM & Kaw Dam-Arkansas River & 3,576 & 75 & 3,651 & 9,213 & 618.8 & 33,750 & 108.5 & 108,000 & 75.8 \\
\hline COONC & Coon Creek-Red Rock Creek & 126 & 9 & 135 & 522 & 15.1 & 3,468 & 6.7 & 22,510 & 5.1 \\
\hline SLARK & Sooner Lake-Arkansas River & 5,562 & 193 & 5,755 & 16,800 & 917.3 & 58,890 & 160.4 & 147,400 & 117.3 \\
\hline CBEAR & Crystal Creek-Black Bear Creek & 258 & 12 & 270 & 828 & 40.4 & 4,840 & 16.2 & 22,180 & 13.3 \\
\hline UBIRD & Upper Bird Creek & 0 & 162 & 162 & 383 & 35.2 & 2,059 & 13.2 & 14,680 & 10.2 \\
\hline ONIHM & $\begin{array}{l}\text { Osage Nation integrated } \\
\text { hydrologic model }\end{array}$ & 5,804 & 1,616 & 7,420 & 17,960 & 2.6 & 62,040 & 1.3 & 147,600 & 1.0 \\
\hline
\end{tabular}


Table 14A. Simulated streamflow for water years 1938-2014, boundary inflows from upstream drainages included, Osage Nation watershed model mean (ONWM), Oklahoma and Kansas.-Continued

$\left[\mathrm{ft}^{3} / \mathrm{s}\right.$, cubic feet per second; - , not applicable]

\begin{tabular}{|c|c|c|c|c|c|c|c|c|c|c|}
\hline \multirow{3}{*}{$\begin{array}{l}\text { Subbasin } \\
\text { or subbasin } \\
\text { group code }\end{array}$} & \multirow{3}{*}{$\begin{array}{l}\text { Subbasin or } \\
\text { subbasin group name }\end{array}$} & \multicolumn{3}{|c|}{ Mean streamflow for water years 1938-2014 } & \multicolumn{6}{|c|}{ Maximum and minimum subbasin outflow (streamflow) water years 1938-2014 } \\
\hline & & \multirow{2}{*}{$\begin{array}{c}\text { Inflows from } \\
\text { upstream } \\
\text { drainages } \\
\left(\mathrm{ft}^{3} / \mathrm{s}\right)\end{array}$} & \multirow{2}{*}{$\begin{array}{c}\text { Subbasin } \\
\text { contributing } \\
\text { streamflow } \\
\left(\mathrm{ft}^{3} / \mathrm{s}\right)\end{array}$} & \multirow{2}{*}{$\begin{array}{c}\text { Subbasin } \\
\text { total outflow } \\
\left(\mathrm{ft}^{3} / \mathrm{s}\right)\end{array}$} & \multicolumn{2}{|c|}{ Annual } & \multicolumn{2}{|c|}{ Monthly } & \multicolumn{2}{|c|}{ Daily } \\
\hline & & & & & $\begin{array}{l}\text { Maximum } \\
\left(\mathrm{ft}^{3} / \mathbf{s}\right)\end{array}$ & $\underset{\left(\mathrm{ft}^{3} / \mathbf{s}\right)}{\text { Minimum }}$ & $\begin{array}{l}\text { Maximum } \\
\left(\mathrm{ft}^{3} / \mathbf{s}\right)\end{array}$ & $\begin{array}{l}\text { Minimum } \\
\left(\mathrm{ft}^{3} / \mathbf{s}\right)\end{array}$ & $\begin{array}{l}\text { Maximum } \\
\left(\mathrm{ft}^{3} / \mathrm{s}\right)\end{array}$ & $\underset{\left(\mathrm{ft}^{3} / \mathbf{s}\right)}{\text { Minimum }}$ \\
\hline LCANE & Lower Caney River & 945 & 307 & 1,252 & 3,152 & 266.2 & 20,210 & 76.3 & 73,910 & 65.8 \\
\hline LBIRD & Lower Bird Creek & 593 & 178 & 771 & 1,760 & 178.2 & 8,957 & 67.8 & 35,250 & 51.9 \\
\hline LWARK & Lower Arkansas River & 8,358 & 194 & 8,552 & 25,330 & 1,706 & 95,000 & 367.1 & 191,700 & 239.7 \\
\hline LICAN & Little Caney River & 0 & 307 & 307 & 844 & 55.0 & 5,203 & 16.3 & 32,710 & 14.4 \\
\hline SKULL & Skull Creek-Cimarron River & 1,530 & 213 & 1,743 & 6,058 & 342.4 & 30,590 & 26.1 & 117,600 & 20.4 \\
\hline KEYCR & Keystone Lake-Cimarron River & 1,743 & 201 & 1,943 & 6,530 & 404.8 & 32,970 & 53.7 & 105,400 & 43.4 \\
\hline POLEC & Polecat Creek & 0 & 225 & 225 & 546 & 34.5 & 2,614 & 13.8 & 17,100 & 10.2 \\
\hline- & Peripheral subbasin group & 8,950 & 1,625 & 10,570 & 25,330 & 34.5 & 95,000 & 13.8 & 191,700 & 10.2 \\
\hline ONWM & Osage Nation watershed model & 6,106 & 4,468 & 10,570 & 25,330 & 0.5 & 95,000 & 0.1 & 191,700 & 0.1 \\
\hline
\end{tabular}

Table 14B. Simulated streamflow for water years 1938-2014, boundary inflows from upstream drainages excluded, Osage Nation watershed model (ONWM), Oklahoma and Kansas.

[ft 3 s, cubic feet per second; - , not applicable]

\begin{tabular}{|c|c|c|c|c|c|c|c|c|c|c|}
\hline \multirow{3}{*}{$\begin{array}{l}\text { Subbasin } \\
\text { or subbasin } \\
\text { group code }\end{array}$} & \multirow{3}{*}{$\begin{array}{c}\text { Subbasin or } \\
\text { subbasin group name }\end{array}$} & \multicolumn{3}{|c|}{ Mean streamflow for water years 1938-2014 } & \multicolumn{6}{|c|}{ Maximum and minimum subbasin outflow (streamflow) water years 1938-2014 } \\
\hline & & \multirow{2}{*}{$\begin{array}{l}\text { Inflows from } \\
\text { upstream } \\
\text { drainages } \\
\left(\mathrm{ft}^{3} / \mathrm{s}\right)\end{array}$} & \multirow{2}{*}{$\begin{array}{c}\text { Subbasin } \\
\text { contributing } \\
\text { streamflow } \\
\left(\mathrm{ft}^{3} / \mathrm{s}\right)\end{array}$} & \multirow{2}{*}{$\begin{array}{c}\text { Subbasin } \\
\text { total } \\
\text { outflow } \\
\left(\mathrm{ft}^{3} / \mathrm{s}\right)\end{array}$} & \multicolumn{2}{|c|}{ Annual } & \multicolumn{2}{|c|}{ Monthly } & \multicolumn{2}{|c|}{ Daily } \\
\hline & & & & & $\begin{array}{l}\text { Maximum } \\
\qquad\left(\mathrm{ft}^{3} / \mathbf{s}\right)\end{array}$ & $\underset{\left(\mathrm{ft}^{3} / \mathrm{s}\right)}{\operatorname{Minimum}}$ & $\begin{array}{c}\text { Maximum } \\
\left(\mathrm{ft}^{3} / \mathrm{s}\right)\end{array}$ & $\underset{\left(\mathrm{ft}^{3} / \mathbf{s}\right)}{\operatorname{Minimum}}$ & $\begin{array}{l}\text { Maximum } \\
\qquad\left(\mathrm{ft}^{3} / \mathrm{s}\right)\end{array}$ & $\begin{array}{c}\text { Minimum } \\
\left(\mathrm{ft}^{3} / \mathrm{s}\right)\end{array}$ \\
\hline CEDAR & Cedar Creek & 0 & 23 & 23 & 64 & 2.2 & 385 & 0.2 & 5,742 & 0.2 \\
\hline SYCAM & Sycamore Creek-Caney River & 0 & 274 & 274 & 719 & 46.3 & 4,299 & 16.3 & 28,620 & 15.0 \\
\hline HBEAV & Headwaters Beaver Creek & 0 & 15 & 15 & 53 & 0.5 & 328 & 0.1 & 4,579 & 0.1 \\
\hline ULBEA & Upper Little Beaver Creek & 0 & 17 & 17 & 67 & 1.0 & 333 & 0.2 & 5,140 & 0.2 \\
\hline KAWLK & Kaw Lake-Arkansas River & 0 & 373 & 373 & 1,051 & 51.9 & 5,832 & 16.7 & 34,880 & 14.8 \\
\hline SALTF & Salt Fork Arkansas River & 0 & 141 & 141 & 587 & 22.3 & 2,849 & 9.8 & 19,020 & 7.8 \\
\hline MREDR & Middle Red Rock Creek & 0 & 126 & 126 & 487 & 13.5 & 3,063 & 5.9 & 22,940 & 4.6 \\
\hline LBEAR & Lower Black Bear Creek & 0 & 228 & 228 & 716 & 36.0 & 4,158 & 15.2 & 18,710 & 12.4 \\
\hline LCAMP & Lower Camp Creek & 0 & 30 & 30 & 96 & 1.6 & 635 & 0.2 & 7,628 & 0.2 \\
\hline
\end{tabular}


Table 14B. Simulated streamflow for water years 1938-2014, boundary inflows from upstream drainages excluded, Osage Nation watershed model (ONWM), Oklahoma and Kansas.-Continued

[ $\mathrm{ft}^{3} / \mathrm{s}$, cubic feet per second; - , not applicable]

\begin{tabular}{|c|c|c|c|c|c|c|c|c|c|c|}
\hline \multirow{3}{*}{$\begin{array}{l}\text { Subbasin } \\
\text { or subbasin } \\
\text { group code }\end{array}$} & \multirow{3}{*}{$\begin{array}{c}\text { Subbasin or } \\
\text { subbasin group name }\end{array}$} & \multicolumn{3}{|c|}{ Mean streamflow for water years 1938-2014 } & \multicolumn{6}{|c|}{ Maximum and minimum subbasin outflow (streamflow) water years 1938-2014 } \\
\hline & & \multirow{2}{*}{$\begin{array}{l}\text { Inflows from } \\
\text { upstream } \\
\text { drainages } \\
\left(\mathrm{ft}^{3} / \mathrm{s}\right)\end{array}$} & \multirow{2}{*}{$\begin{array}{c}\text { Subbasin } \\
\text { contributing } \\
\text { streamflow } \\
\left(\mathrm{ft}^{3} / \mathrm{s}\right)\end{array}$} & \multirow{2}{*}{$\begin{array}{c}\text { Subbasin } \\
\text { total } \\
\text { outflow } \\
\text { (ft } / \mathbf{s})\end{array}$} & \multicolumn{2}{|c|}{ Annual } & \multicolumn{2}{|c|}{ Monthly } & \multicolumn{2}{|c|}{ Daily } \\
\hline & & & & & $\begin{array}{l}\text { Maximum } \\
\left(\mathrm{ft}^{3} / \mathrm{s}\right)\end{array}$ & $\begin{array}{c}\text { Minimum } \\
\left(\mathrm{ft}^{3} / \mathrm{s}\right)\end{array}$ & $\begin{array}{c}\text { Maximum } \\
\left(\mathrm{ft}^{3} / \mathbf{s}\right)\end{array}$ & $\underset{\left(\mathrm{ft}^{3} / \mathrm{s}\right)}{\text { Minimum }}$ & $\begin{array}{l}\text { Maximum } \\
\left(\mathrm{ft}^{3} / \mathbf{s}\right)\end{array}$ & $\begin{array}{c}\text { Minimum } \\
\left(\mathrm{ft}^{3} / \mathrm{s}\right)\end{array}$ \\
\hline- & Upstream subbasin group & 0 & 1,227 & 1,227 & 1,051 & 0.5 & 5,832 & 0.1 & 34,880 & 0.1 \\
\hline MCANE & Middle Caney River & 421 & 55 & 476 & 1,209 & 94.4 & 7,728 & 32.2 & 40,290 & 28.5 \\
\hline BUTLR & Butler Creek & 0 & 15 & 15 & 42 & 2.6 & 235 & 1.3 & 2,614 & 1.1 \\
\hline SANDC & Sand Creek & 0 & 147 & 147 & 352 & 27.5 & 2,047 & 9.6 & 14,380 & 7.3 \\
\hline CBIRD & Charlie Creek-Bird Creek & 162 & 151 & 313 & 736 & 65.0 & 3,921 & 24.6 & 18,530 & 19.4 \\
\hline HOMCK & Rock Creek-Hominy Creek & 0 & 246 & 246 & 610 & 55.3 & 3,028 & 29.5 & 18,350 & 24.2 \\
\hline DELAW & Delaware Creek & 0 & 34 & 34 & 81 & 5.4 & 423 & 1.3 & 3,189 & 1.0 \\
\hline KEYAR & Keystone Lake-Arkansas River & 1,449 & 164 & 1,613 & 4,897 & 330.0 & 28,620 & 143.8 & 84,660 & 126.9 \\
\hline UCANE & Upper Caney River & 298 & 124 & 421 & 1,090 & 85.3 & 6,883 & 28.2 & 40,670 & 25.7 \\
\hline LBEAV & Lower Beaver Creek & 32 & 57 & 89 & 303 & 15.2 & 1,515 & 6.6 & 14,110 & 5.8 \\
\hline BEARC & Bear Creek & 373 & 40 & 412 & 1,162 & 70.3 & 6,502 & 26.4 & 32,910 & 23.4 \\
\hline SALTC & Salt Creek & 0 & 133 & 133 & 377 & 12.6 & 2,454 & 4.0 & 14,310 & 2.8 \\
\hline KAWDM & Kaw Dam-Arkansas River & 501 & 75 & 576 & 1,688 & 114.5 & 9,448 & 47.9 & 41,640 & 42.6 \\
\hline COONC & Coon Creek-Red Rock Creek & 126 & 9 & 135 & 522 & 15.1 & 3,468 & 6.7 & 22,510 & 5.1 \\
\hline SLARK & Sooner Lake-Arkansas River & 986 & 193 & 1,179 & 3,710 & 220.2 & 21,900 & 95.4 & 73,500 & 81.7 \\
\hline CBEAR & Crystal Creek-Black Bear Creek & 258 & 12 & 270 & 828 & 40.4 & 4,840 & 16.2 & 22,180 & 13.3 \\
\hline UBIRD & Upper Bird Creek & 0 & 162 & 162 & 383 & 35.2 & 2,059 & 13.2 & 14,680 & 10.2 \\
\hline ONIHM & $\begin{array}{l}\text { Osage Nation integrated } \\
\text { hydrologic model }\end{array}$ & 1,227 & 1,616 & 2,843 & 4,897 & 2.6 & 28,620 & 1.3 & 84,660 & 1.0 \\
\hline LCANE & Lower Caney River & 945 & 307 & 1,252 & 3,152 & 266.2 & 20,210 & 76.3 & 73,910 & 65.8 \\
\hline LBIRD & Lower Bird Creek & 593 & 178 & 771 & 1,760 & 178.2 & 8,957 & 67.8 & 35,250 & 51.9 \\
\hline LWARK & Lower Arkansas River & 2,251 & 194 & 2,445 & 6,752 & 614.9 & 36,380 & 241.6 & 90,590 & 209.0 \\
\hline LICAN & Little Caney River & 0 & 307 & 307 & 844 & 55.0 & 5,203 & 16.3 & 32,710 & 14.4 \\
\hline SKULL & Skull Creek-Cimarron River & 0 & 213 & 213 & 655 & 47.6 & 3,530 & 22.1 & 20,760 & 18.0 \\
\hline KEYCR & Keystone Lake-Cimarron River & 213 & 201 & 413 & 1,218 & 92.5 & 6,291 & 48.0 & 26,850 & 41.2 \\
\hline POLEC & Polecat Creek & 0 & 225 & 225 & 546 & 34.5 & 2,614 & 13.8 & 17,100 & 10.2 \\
\hline- & Peripheral subbasin group & 2,843 & 1,625 & 4,468 & 6,752 & 34.5 & 36,380 & 13.8 & 90,590 & 10.2 \\
\hline ONWM & Osage Nation watershed model & 0 & 4,468 & 4,468 & 6,752 & 0.5 & 36,380 & 0.1 & 90,590 & 0.1 \\
\hline
\end{tabular}


Table 14C. Simulated difference in streamflow for water years 1938-2014, results for simulations with inflows from upstream drainages included minus results for simulations with inflows excluded, Osage Nation watershed model (ONWM), Oklahoma and Kansas.

$\left[\mathrm{ft}^{3} / \mathrm{s}\right.$, cubic feet per second; - , not applicable]

\begin{tabular}{|c|c|c|c|c|c|c|c|c|c|c|}
\hline \multirow{3}{*}{$\begin{array}{l}\text { Subbasin } \\
\text { or subbasin } \\
\text { group code }\end{array}$} & \multirow{3}{*}{$\begin{array}{l}\text { Subbasin or } \\
\text { subbasin group name }\end{array}$} & \multicolumn{3}{|c|}{$\begin{array}{l}\text { Difference in mean streamflow } \\
\text { for water years, 1938-2014 }\end{array}$} & \multicolumn{6}{|c|}{$\begin{array}{l}\text { Difference in maximum and minimum subbasin outflow (streamflow) } \\
\text { water years 1938-2014 }\end{array}$} \\
\hline & & \multirow{2}{*}{$\begin{array}{l}\text { Inflows from } \\
\text { upstream } \\
\text { drainages } \\
\left(\mathrm{ft}^{3} / \mathrm{s}\right)\end{array}$} & \multirow{2}{*}{$\begin{array}{c}\text { Subbasin } \\
\text { contributing } \\
\text { streamflow } \\
\left(\mathrm{ft}^{3} / \mathrm{s}\right)\end{array}$} & \multirow{2}{*}{$\begin{array}{c}\text { Subbasin } \\
\text { total } \\
\text { outflow } \\
\left(\mathrm{ft}^{3} / \mathrm{s}\right)\end{array}$} & \multicolumn{2}{|c|}{ Annual } & \multicolumn{2}{|c|}{ Monthly } & \multicolumn{2}{|c|}{ Daily } \\
\hline & & & & & $\begin{array}{l}\text { Maximum } \\
\left(\mathrm{ft}^{3} / \mathrm{s}\right)\end{array}$ & $\begin{array}{l}\text { Minimum } \\
\left(\mathrm{ft}^{3} / \mathrm{s}\right)\end{array}$ & $\begin{array}{l}\text { Maximum } \\
\left(\mathrm{ft}^{3} / \mathrm{s}\right)\end{array}$ & $\begin{array}{l}\text { Minimum } \\
\left(\mathrm{ft}^{3} / \mathrm{s}\right)\end{array}$ & $\begin{array}{l}\text { Maximum } \\
\left(\left(\mathrm{ft}^{3} / \mathbf{s}\right)\right.\end{array}$ & $\begin{array}{l}\text { Minimum } \\
\left(\mathrm{ft}^{3} / \mathbf{s}\right)\end{array}$ \\
\hline CEDAR & Cedar Creek & 0 & 0 & 0 & 0 & 0.0 & 0 & 0.0 & 0 & 0.0 \\
\hline SYCAM & Sycamore Creek-Caney River & 0 & 0 & 0 & 0 & 0.0 & 0 & 0.0 & 0 & 0.0 \\
\hline HBEAV & Headwaters Beaver Creek & 0 & 0 & 0 & 0 & 0.0 & 0 & 0.0 & 0 & 0.0 \\
\hline ULBEA & Upper Little Beaver Creek & 0 & 0 & 0 & 0 & 0.0 & 0 & 0.0 & 0 & 0.0 \\
\hline KAWLK & Kaw Lake-Arkansas River & 3,075 & 0 & 3,075 & 7,758 & 507.6 & 25,200 & 46.4 & 91,610 & 30.8 \\
\hline SALTF & Salt Fork Arkansas River & 1,502 & 0 & 1,502 & 5,732 & 169.4 & 20,100 & 2.4 & 62,310 & 1.3 \\
\hline MREDR & Middle Red Rock Creek & 0 & 0 & 0 & 0 & 0.0 & 0 & 0.0 & 0 & 0.0 \\
\hline LBEAR & Lower Black Bear Creek & 0 & 0 & 0 & 0 & 0.0 & 0 & 0.0 & 0 & 0.0 \\
\hline LCAMP & Lower Camp Creek & 0 & 0 & 0 & 0 & 0.0 & 0 & 0.0 & 0 & 0.0 \\
\hline - & Upstream subbasin group & 4,576 & 0 & 4,576 & 7,758 & 0.0 & 25,200 & 0.0 & 91,610 & 0.0 \\
\hline MCANE & Middle Caney River & 0 & 0 & 0 & 0 & 0.0 & 0 & 0.0 & 0 & 0.0 \\
\hline BUTLR & Butler Creek & 0 & 0 & 0 & 0 & 0.0 & 0 & 0.0 & 0 & 0.0 \\
\hline SANDC & Sand Creek & 0 & 0 & 0 & 0 & 0.0 & 0 & 0.0 & 0 & 0.0 \\
\hline CBIRD & Charlie Creek-Bird Creek & 0 & 0 & 0 & 0 & 0.0 & 0 & 0.0 & 0 & 0.0 \\
\hline HOMCK & Rock Creek-Hominy Creek & 0 & 0 & 0 & 0 & 0.0 & 0 & 0.0 & 0 & 0.0 \\
\hline DELAW & Delaware Creek & 0 & 0 & 0 & 0 & 0.0 & 0 & 0.0 & 0 & 0.0 \\
\hline KEYAR & Keystone Lake-Arkansas River & 4,576 & 0 & 4,576 & 13,060 & 722.0 & 33,420 & 58.7 & 62,920 & 31.2 \\
\hline UCANE & Upper Caney River & 0 & 0 & 0 & 0 & 0.0 & 0 & 0.0 & 0 & 0.0 \\
\hline LBEAV & Lower Beaver Creek & 0 & 0 & 0 & 0 & 0.0 & 0 & 0.0 & 0 & 0.0 \\
\hline BEARC & Bear Creek & 3,075 & 0 & 3,075 & 7,715 & 505.6 & 24,570 & 52.2 & 86,660 & 32.1 \\
\hline SALTC & Salt Creek & 0 & 0 & 0 & 0 & 0.0 & 0 & 0.0 & 0 & 0.0 \\
\hline KAWDM & Kaw Dam-Arkansas River & 3,075 & 0 & 3,075 & 7,525 & 504.3 & 24,300 & 60.6 & 66,360 & 33.2 \\
\hline COONC & Coon Creek-Red Rock Creek & 0 & 0 & 0 & 0 & 0.0 & 0 & 0.0 & 0 & 0.0 \\
\hline SLARK & Sooner Lake-Arkansas River & 4,576 & 0 & 4,576 & 13,090 & 697.1 & 36,990 & 65.1 & 73,920 & 35.5 \\
\hline CBEAR & Crystal Creek-Black Bear Creek & 0 & 0 & 0 & 0 & 0.0 & 0 & 0.0 & 0 & 0.0 \\
\hline UBIRD & Upper Bird Creek & 0 & 0 & 0 & 0 & 0.0 & 0 & 0.0 & 0 & 0.0 \\
\hline ONIHM & $\begin{array}{l}\text { Osage Nation integrated } \\
\text { hydrologic model }\end{array}$ & 4,576 & 0 & 4,576 & 13,090 & 0.0 & 36,990 & 0.0 & 86,660 & 0.0 \\
\hline
\end{tabular}


Table 14C. Simulated difference in streamflow for water years 1938-2014, results for simulations with inflows from upstream drainages included minus results for simulations with inflows excluded, Osage Nation watershed model (ONWM), Oklahoma and Kansas.-Continued

[ $\mathrm{ft}^{3} / \mathrm{s}$, cubic feet per second; - , not applicable]

\begin{tabular}{|c|c|c|c|c|c|c|c|c|c|c|}
\hline \multirow{3}{*}{$\begin{array}{l}\text { Subbasin } \\
\text { or subbasin } \\
\text { group code }\end{array}$} & \multirow{3}{*}{$\begin{array}{l}\text { Subbasin or } \\
\text { subbasin group name }\end{array}$} & \multicolumn{3}{|c|}{$\begin{array}{l}\text { Difference in mean streamflow } \\
\text { for water years, 1938-2014 }\end{array}$} & \multicolumn{6}{|c|}{$\begin{array}{l}\text { Difference in maximum and minimum subbasin outflow (streamflow) } \\
\text { water years 1938-2014 }\end{array}$} \\
\hline & & \multirow{2}{*}{$\begin{array}{l}\text { Inflows from } \\
\text { upstream } \\
\text { drainages } \\
\left(\mathrm{ft}^{3} / \mathrm{s}\right)\end{array}$} & \multirow{2}{*}{$\begin{array}{c}\text { Subbasin } \\
\text { contributing } \\
\text { streamflow } \\
\left(\mathrm{ft}^{3} / \mathrm{s}\right)\end{array}$} & \multirow{2}{*}{$\begin{array}{l}\text { Subbasin } \\
\text { total } \\
\text { outflow } \\
\left(\mathrm{ft}^{3} / \mathrm{s}\right)\end{array}$} & \multicolumn{2}{|c|}{ Annual } & \multicolumn{2}{|c|}{ Monthly } & \multicolumn{2}{|c|}{ Daily } \\
\hline & & & & & $\begin{array}{l}\text { Maximum } \\
\left(\mathrm{ft}^{3} / \mathbf{s}\right)\end{array}$ & $\begin{array}{l}\text { Minimum } \\
\left(\mathrm{ft}^{3} / \mathrm{s}\right)\end{array}$ & $\begin{array}{l}\text { Maximum } \\
\left(\mathrm{ft}^{3} / \mathrm{s}\right)\end{array}$ & $\begin{array}{l}\text { Minimum } \\
\left(\mathrm{ft}^{3} / \mathrm{s}\right)\end{array}$ & $\begin{array}{l}\text { Maximum } \\
\left(\mathrm{ft}^{3} / \mathrm{s}\right)\end{array}$ & $\begin{array}{l}\text { Minimum } \\
\left(\mathrm{ft}^{3} / \mathbf{s}\right)\end{array}$ \\
\hline LCANE & Lower Caney River & 0 & 0 & 0 & 0 & 0.0 & 0 & 0.0 & 0 & 0.0 \\
\hline LBIRD & Lower Bird Creek & 0 & 0 & 0 & 0 & 0.0 & 0 & 0.0 & 0 & 0.0 \\
\hline LWARK & Lower Arkansas River & 6,106 & 0 & 6,106 & 18,570 & 1,091 & 58,610 & 125.5 & 101,100 & 30.7 \\
\hline LICAN & Little Caney River & 0 & 0 & 0 & 0 & 0.0 & 0 & 0.0 & 0 & 0.0 \\
\hline SKULL & Skull Creek-Cimarron River & 1,530 & 0 & 1,530 & 5,404 & 294.8 & 27,060 & 4.0 & 96,800 & 2.4 \\
\hline KEYCR & Keystone Lake-Cimarron River & 1,530 & 0 & 1,530 & 5,312 & 312.3 & 26,680 & 5.7 & 78,600 & 2.2 \\
\hline POLEC & Polecat Creek & 0 & 0 & 0 & 0 & 0.0 & 0 & 0.0 & 0 & 0.0 \\
\hline- & Peripheral subbasin group & 6,106 & 0 & 6,106 & 18,570 & 0.0 & 58,610 & 0.0 & 101,100 & 0.0 \\
\hline ONWM & Osage Nation watershed model & 6,106 & 0 & 6,106 & 18,570 & 0.0 & 58,610 & 0.0 & 101,100 & 0.0 \\
\hline
\end{tabular}




\section{Annual Results, Water Years 1915-2014}

Annual results for water years 1915-2014 varied substantially from year to year (fig. 50). The primary factor affecting the year-to-year variability in ET, streamflow, groundwater losses, recharge, and changes in water storage was the variability in precipitation. The wettest year in the 100 -year simulation period was water year 1999 with 57.8 inches of precipitation and outflows from the ONWM area of 34.0 inches ET, 18.8 inches (about 10,530 ft3/s) streamflow, and 2.5 inches groundwater outflows (groundwater losses), along with an increase in storage of 2.4 inches (fig. 50). Water year 1956 was the driest year in the simulation period with only 18.5 inches of precipitation, 18.0 inches ET, 2.1 inches $\left(1,279 \mathrm{ft}^{3} / \mathrm{s}\right)$ streamflow, 0.4 inches of groundwater losses, and a decrease in storage of 1.9 inches. For all 7 years with at least 50 inches of precipitation, streamflow was 13.5 inches $\left(8,291 \mathrm{ft}^{3} / \mathrm{s}\right)$ or greater, ET was 30.6 inches or greater, and groundwater losses were 1.7 inches or greater. The mean increase in storage for these 7 years was 1.8 inches and varied from a minimum of 0.54 inches for water year 2008 to a maximum of 3.5 inches for water year 1985 .

The largest component of water storage and year to year changes in water storage was soil moisture. The 100-year mean soil moisture was 2.4 inches, and annual mean soil moisture ranged from a minimum of 1.5 inches for water years 1956 to a maximum of 3.3 inches for water years 1999 and 1942 (fig. 50B). Compared to ET and soil moisture, recharge and streamflow varied more on an annual basis. Recharge (soil-zone recharge and seepage from depressions combined) ranged from a minimum of 1.5 inches for water year 1956 to a maximum of 8.8 inches for water year 1999. Annual streamflow ranged from a minimum of 1.7 inches $\left(1,044 \mathrm{ft}^{3} / \mathrm{s}\right)$ for water year 1966 to a maximum of 18.8 inches (about $11,550 \mathrm{ft}^{3} / \mathrm{s}$ ) for water year 1999. Streamflow was greater than 10 inches $\left(6,142 \mathrm{ft}^{3} / \mathrm{s}\right)$ for 20 of the wetter years and less than 3 inches $\left(1,842 \mathrm{ft}^{3} / \mathrm{s}\right)$ for 14 of the driest years. Groundwater losses averaged about 28 percent of recharge for the 100-year period, and was less than recharge for all years, ranging from
0.38 inches ( 25 percent of recharge) for water year 1956 to 2.5 inches (29 percent of recharge) for water year 1999.

The basinwide annual results for the ONIHM area were compared to basinwide annual results for selected subbasins (fig. 51). Comparison of annual precipitation in the ONIHM area and the Lower Bird Creek and Middle Red Rock Creek subbasins indicated that water year 1973 was the wettest year in the Lower Bird Creek subbasin, whereas water year 1999 was the wettest year in the ONIHM area and the Middle Red Rock Creek subbasin (fig. 51A). Water year 1956 was the driest in the ONIHM area as well as in the two subbasins. Results for basinwide annual ET also indicated variability in the relative differences in annual ET between the different areas (fig. 51B). Water year 2007 had the greatest basinwide ET of 37.2 inches in the Polecat Creek subbasin, whereas water year 1927 had the greatest basinwide ET of 35.3 inches in the ONIHM area and 31.2 inches in the Bear Creek subbasin. Relative differences in basinwide annual water storage and recharge were generally more consistent between different areas. The maximum basinwide water storages were simulated in water year 1999, including 6.5 inches in the ONIHM area, 10.2 inches in the Kaw Dam-Arkansas River subbasin, and 4.2 inches in the Middle Red Rock Creek subbasin (fig. 51C). The maximum annual basinwide recharge amounts were also simulated in water year 1999, including 9.6 inches in the ONIHM area, 14.0 inches in the Lower Arkansas River subbasin, and 2.0 inches in the Lower Camp Creek subbasin (fig. 51D). The minimum amounts for water storage and recharge generally were simulated for water years 1955 or 1956 for the ONIHM and the two subbasins. Minimum simulated water storage amounts were 5.7 inches in the Kaw Dam-Arkansas River subbasin and 3.2 inches in the ONIHM area during water year 1956, and 1.6 inches in the Middle Red Rock Creek subbasin during water year 1955. Minimum simulated recharge amounts were 3.8 inches in the Lower Arkansas River subbasin during water year 1956, 1.8 inches in the ONIHM area during water year 1956, and 0.19 inch in the Lower Camp Creek subbasin during water year 1925. 

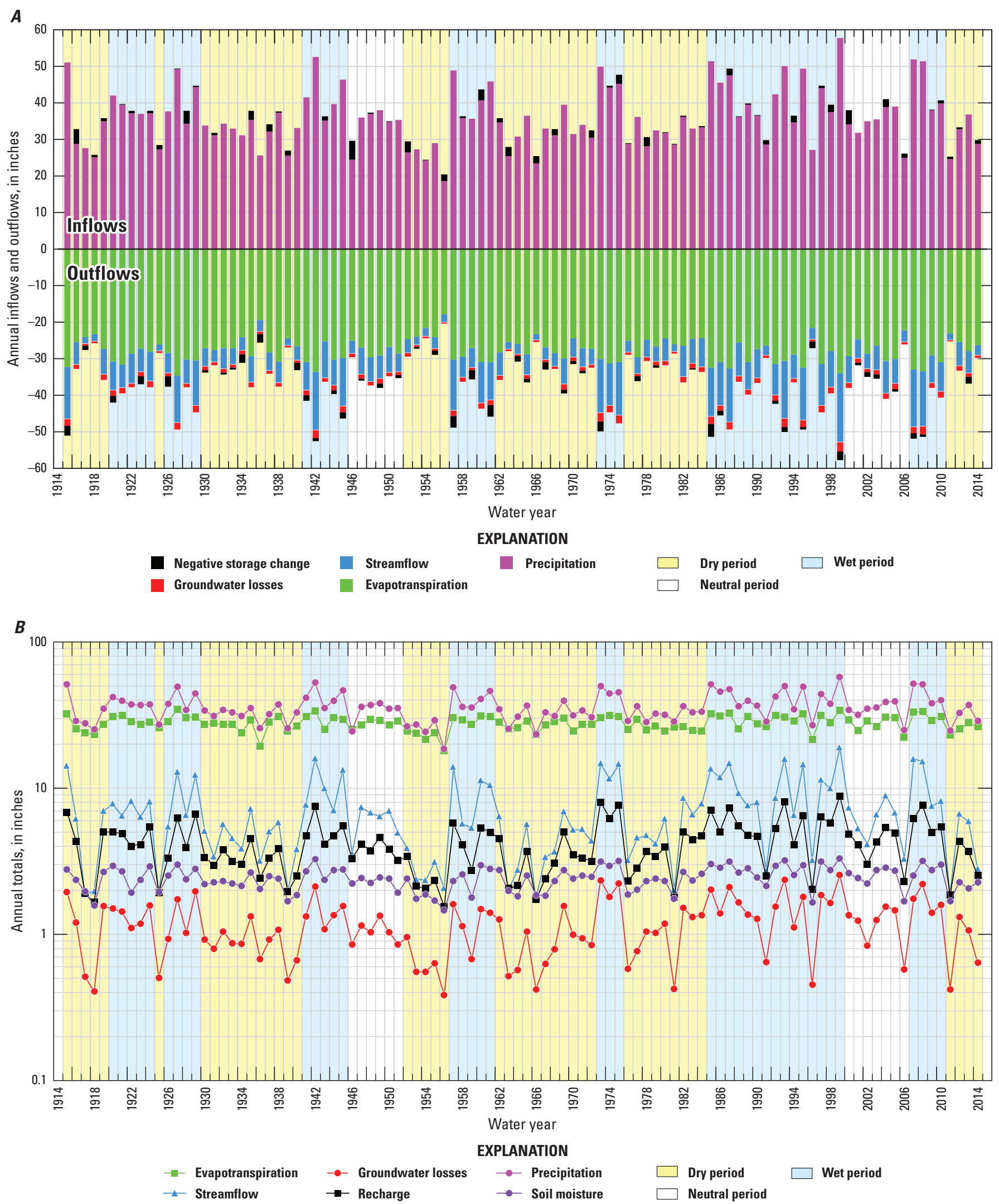

Figure 50. Simulated annual results using the Osage Nation watershed model, water years 1915-2014, Oklahoma and Kansas: $A$, inflows, outflows, and changes in storage, and $B$, totals for selected water-budget components. 

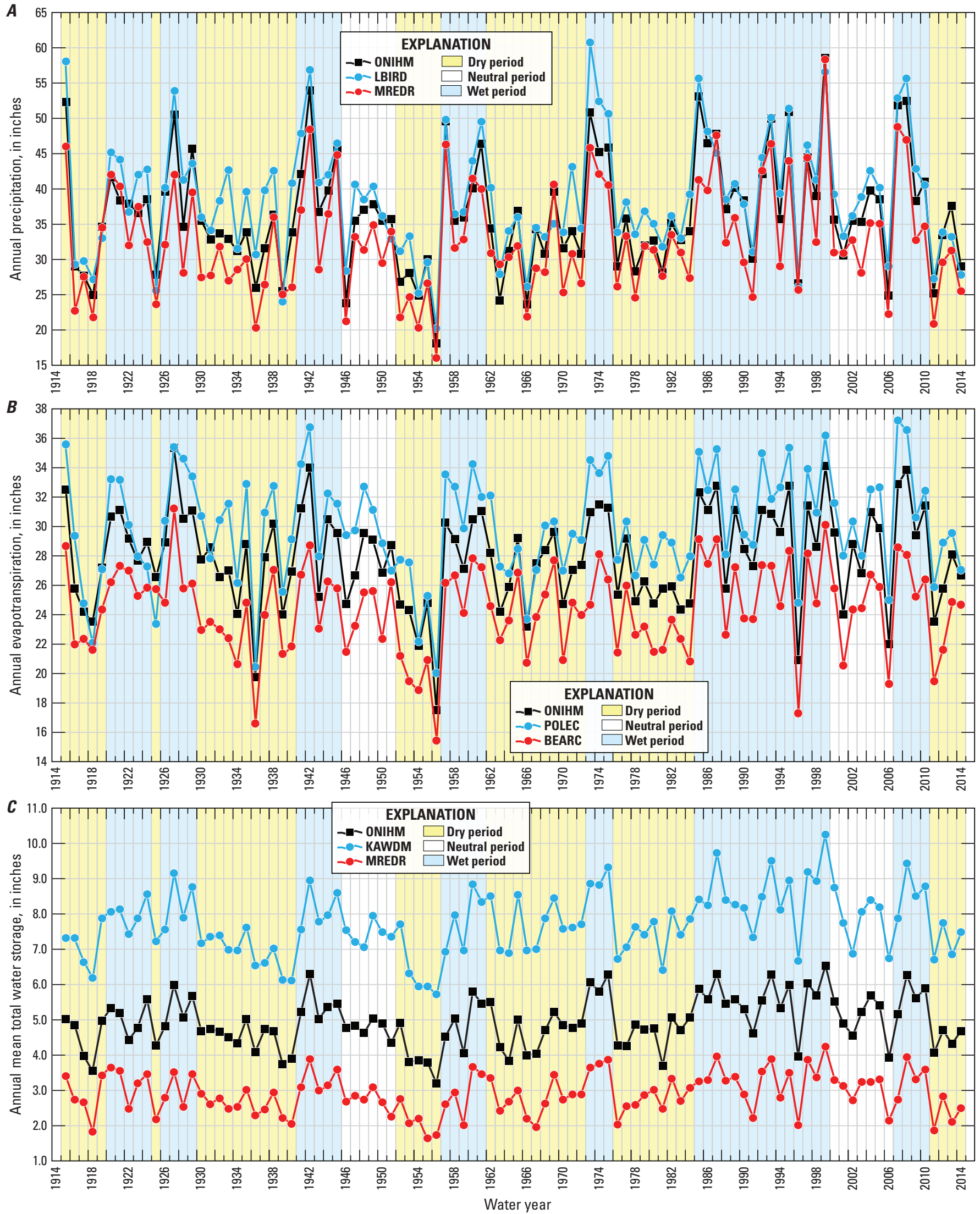

Figure 51. Simulated annual results for water years 1915-2014 for the area of the Osage Nation integrated hydrologic model and selected subbasin areas, the Osage Nation watershed model, Oklahoma and Kansas: $A$, precipitation; $B$, evapotranspiration (ET); $C$, total water storage; $D$, recharge; $E$, groundwater losses; and $F$, streamflow. 

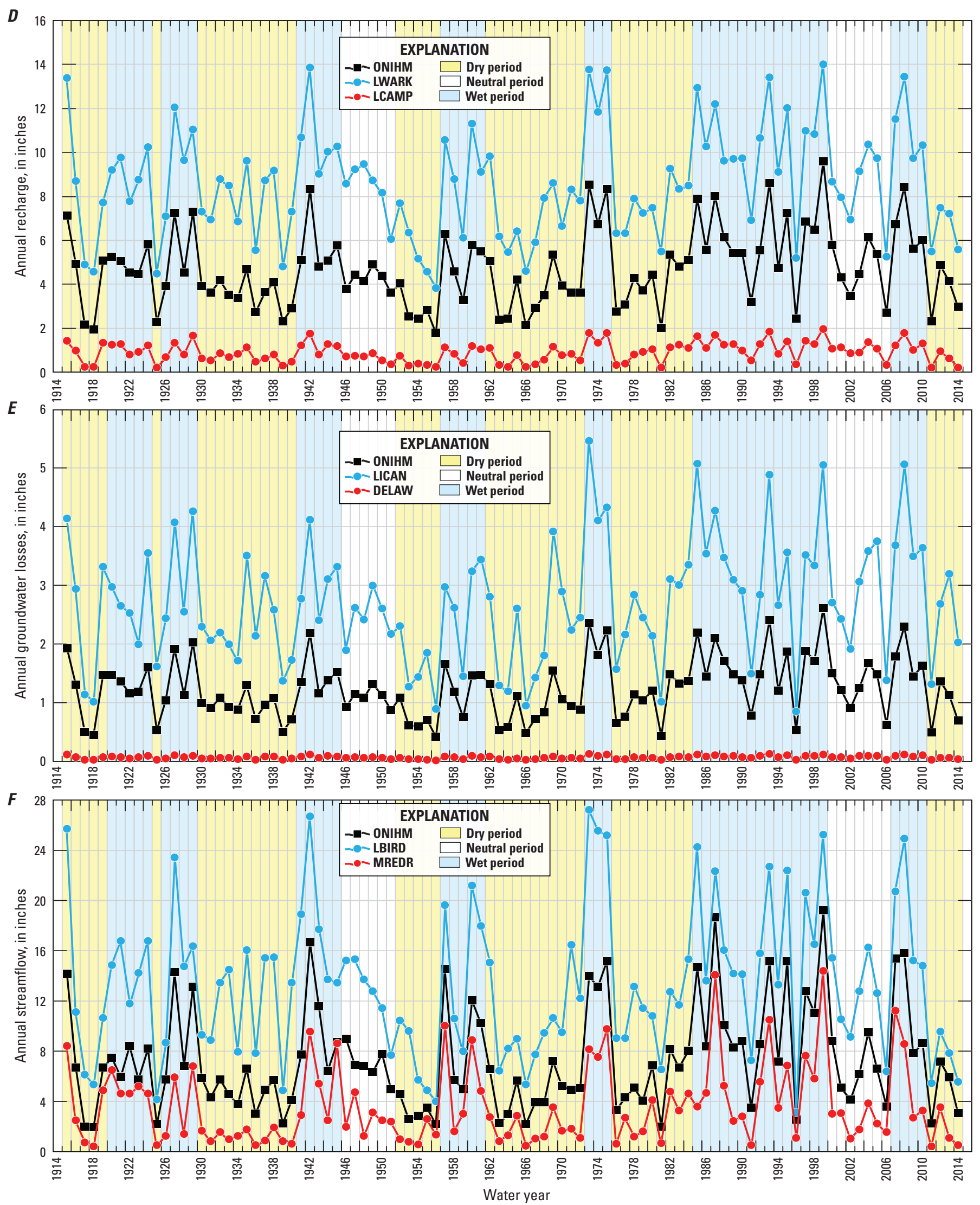

Figure 51. - Continued 
Compared to other components of the water budget, results for annual groundwater losses were the most variable between different subbasins (fig. 51E; table 12A). The largest annual groundwater loss in the ONIHM was 2.6 inches in 1999. In comparison, the largest annual groundwater loss in the Little Caney River subbasin was 5.5 inches in 1973, and the largest annual groundwater loss in the Delaware Creek subbasin was 0.13 inch in 1993 and 1973. The smallest annual groundwater loss in the ONIHM was 0.41 inch in water year 1956, and the smallest annual groundwater loss in the Delaware Creek subbasin, 0.013 inch, was also in water year 1956, whereas the smallest groundwater loss in the Little Caney River subbasin, 0.85 inch, was in water year 1996. Annual streamflow was analyzed in terms of the equivalent basinwide water depth (in inches) to more directly compare relative amounts of streamflow discharges among different areas and also to other components of the water budget; comparisons of streamflow based on daily mean streamflow rates (in cubic feet per second) indicate the discharge volume, which is dependent on the size of the drainage area. Annual streamflow was the most variable from year-to-year compared to other water-budget components for all subbasins and subbasin groups of the ONWM (fig. 51F; tables 12, 13). In addition, compared to other water-budget components, the year-to-year variability in streamflow was not as consistent among the different areas of the ONWM. Maximum and minimum annual streamflows were simulated for different water years in different subbasins. The highest annual streamflow in the Lower Bird Creek subbasin was 27.2 inches in water year 1973 (fig. $51 F$ ), whereas the highest annual streamflow in the Middle Red Rock Creek subbasin was 14.4 inches in water year 1999. The lowest annual streamflow in the Lower Bird Creek subbasin was 3.1 inches in 1996, whereas the lowest annual streamflow in the ONIHM area was 1.9 inches in 1918, and the lowest annual streamflow in the Middle Red Rock Creek subbasin was 0.4 inch in 2011.

\section{Monthly Results, Water Years 1915-2014}

Monthly simulation results from the ONWM were used to analyze temporal variability and cycles in the monthly time series of recharge and streamflow and also to analyze mean monthly values for selected water-budget components. The standardized runoff-index method (Shukla and Wood, 2008) was applied to the monthly recharge and streamflow results using a 48-month (4-year) sliding-analysis window to identify periods when departures from the 100-year mean monthly values were notable. In addition, the 48-month (4-year) LOWESS curves and the cumulative departures from the 100 -year mean monthly recharge and streamflow were used to identify wet and dry periods in the monthly results.

\section{Monthly Recharge and Streamflow}

The monthly time series of recharge (soil-zone recharge and seepage from depressions combined), expressed as the mean value for the ONWM area, varied from low values of about 0.1 inch and less for 69 months to high values of more than 1.0 inch (for total monthly recharge) for 37 months (fig. 52A). In comparison, the mean monthly recharge for all 1,200 months was 0.35 inch and the median recharge was 0.26 inch. The monthly recharge was lowest in October 1956 at 0.06 inch and was highest in June 1957 at 1.6 inches. A shift in minimum and maximum monthly values for monthly recharge was indicated by the 4-year LOWESS curve for the period beginning with water year 1973 and ending with water year 1999 (fig. 52A). During this 27-year period, the LOWESS curve reached the highest values, equaling or exceeding 0.5 inch for a total of 18 months during water years 1974 , 1984, and 1998-99. In addition, the minimum values for the LOWESS curve were greater than minimum values for most other periods. Relatively low LOWESS values of 0.2 inch and less, indicating considerably drier conditions compared to mean monthly recharge for the ONWM area, were calculated for only seven months in water year 1976 during the 27-year period. In contrast, LOWESS values of 0.2 inch or less were calculated for 152 months during other periods, including water years 1917-18, 1925-26, 1939-40, 1950, 1952-57, 1963-64, 1966-67, 2006, and 2014.

The cumulative departure from the 100 -year mean monthly recharge also shifted from a generally negative slope, indicating drier than average conditions in terms of recharge, to a generally positive slope, indicating wetter than average conditions, starting with water year 1973 (fig. 52B). The monthly recharge index, calculated using the standardized runoff-index method (Shukla and Wood, 2008) and a 48-month (4-year) interval, was used to indicate periods of notable deviations from the 100-year mean recharge. Recharge index values greater than or equal to 1.0 indicated wetter than average periods in terms of recharge, whereas values less than or equal to -1.0 indicated drier than average periods in terms of recharge. Of the 1,200 months in the simulation period, a recharge index of 1.0 or greater was calculated for 202 months, of which 183 were after water year 1972, and a recharge index of -1.0 or less was calculated for 171 months, of which 155 were prior to water 1973. A recharge index of 1.5 or greater was calculated for 89 months, all after water year 1972, and a recharge index of -1.5 or less was calculated for 87 months, all prior to water 1973. The 89 months with recharge indices of 1.5 or greater defined wetter than average 4-year periods ending on water years 1975-76, 1987-88, 1995, 2000-01, and 2010. The wettest period, with a maximum recharge index of 2.05, was calculated for July and August 2000. The 87 months with recharge indices of -1.5 or less defined drier than average 4 -year periods ending with water years 1939-40, 1954-57, and 1965-68. Much drier than average 4-year periods in terms of recharge, as indicated by a recharge index of -2 or less, were prior to water year 

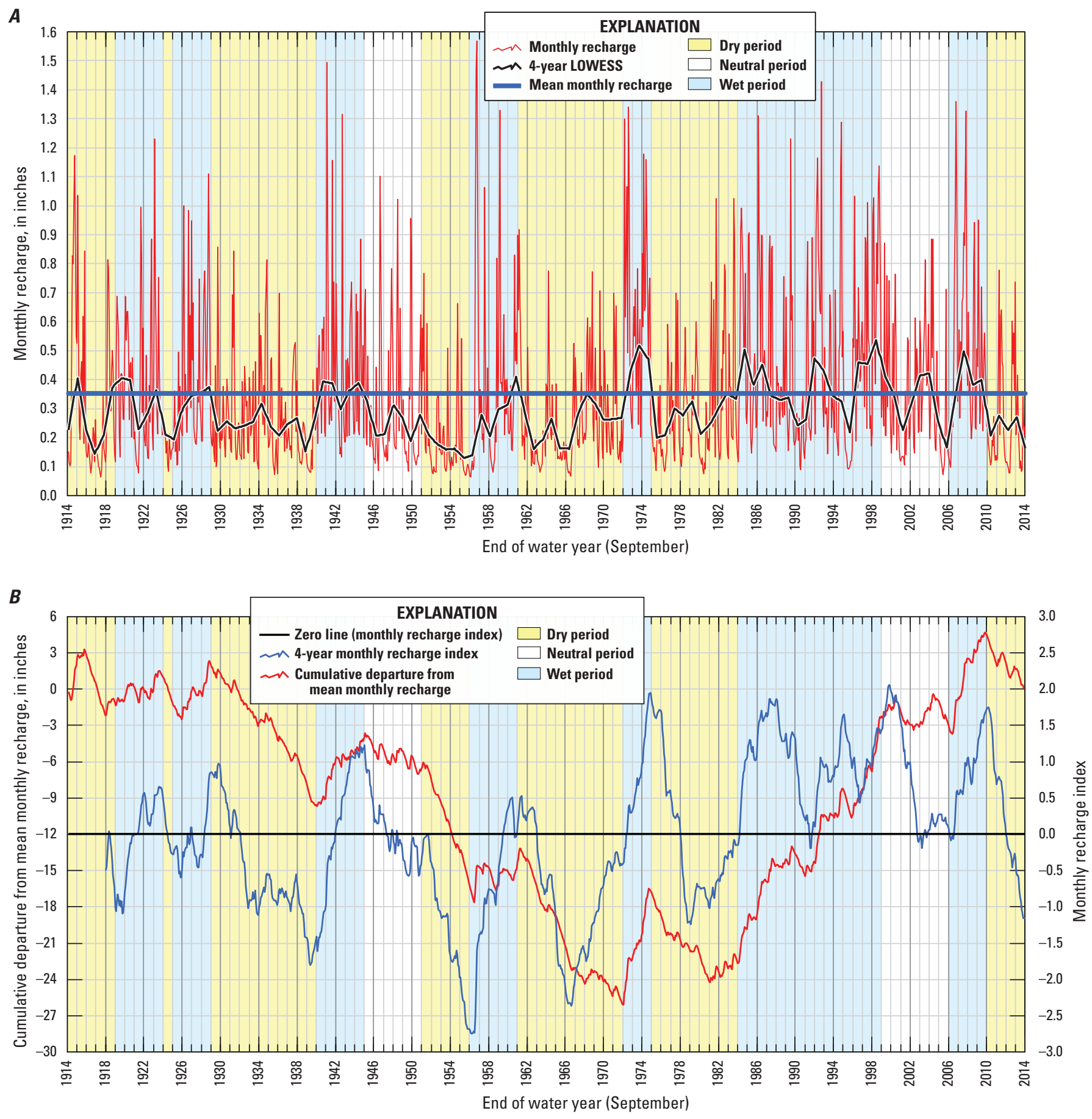

Figure 52. Simulated monthly recharge for water years 1915-2014 using the Osage Nation watershed model, Oklahoma and Kansas: $A$, monthly values and fitted 4-year LOWESS curve, and $B$, cumulative departure from 100-year mean monthly recharge and 4-year monthly recharge index. 
1973, and ended with water years 1955-56 and 1966-67. The driest period, centered on water year 1956, included a minimum recharge index of -2.75 calculated for November and December 1956.

The monthly results for streamflow, simulated as an outflow from the ONWM area and calculated as the total monthly uniform depth of water discharged from the ONWM area, included a 100-year mean monthly streamflow of 0.59 inch and a median streamflow of 0.28 inch. The calculated variance for monthly streamflow was 0.63 inch squared, compared to a variance of only 0.07 inch squared calculated for monthly recharge, indicating a higher variability in streamflow as compared to recharge. A minimum value of 0.05 inch was simulated for February 1918 and a maximum monthly streamflow of 7.1 inches was simulated for May 1943 (fig. 53A). High monthly streamflows of 5 inches or greater were simulated in October 1941, October 1959, October 1986, May 1993, and June 2007. The 4-year LOWESS curve for monthly streamflow indicated a period of maximum monthly streamflows with values of more than 0.7 inch centered on water years 1974-75 (fig. 53A). Other periods with relatively high monthly streamflow as indicated by LOWESS values of 0.5 inch and greater were centered on water years 1920-21, 1985, 1987, 1993, 1997, 1999, 2003-04, and 2008. The minimum LOWESS value of 0.11 inch was calculated for water year 1956. Other dry periods in terms of streamflow, as indicated by LOWESS values less than or equal to 0.2 inch, were centered on water years 1917, 1939, 1963, 1966, 1996, 2006, and 2014.

Similar to the results for monthly recharge, the cumulative departure from mean monthly streamflow also shifted from a generally negative sloping curve prior to about water year 1973, indicating lower than average streamflow for the earlier part of the simulation period, to a generally positive sloping curve starting with water year 1973, indicating higher than average monthly streamflow for the later part of the simulation period (fig. $53 \mathrm{~B}$ ). As with the monthly recharge index, the monthly streamflow index was calculated using the standardized runoff-index method and a 48-month (4-year) interval; values of 1.0 or greater indicated considerably wetter than average periods in terms of monthly streamflow, and values of -1.0 or less indicated considerably drier than average periods in terms of monthly streamflow. Of the 1,200 months in the simulation period, a streamflow index that was greater than or equal to 1.0 was calculated for 225 months, of which 187 were after water year 1972. A streamflow index that was less than or equal to -1.0 was calculated for 188 months, of which 166 were prior to water year 1973. A streamflow index that was greater than or equal to 1.5 was calculated for 88 months, all after water year 1972, whereas a streamflow index that was less than or equal to -1.5 was calculated for 83 months, all prior to water year 1973. The wettest 4-year periods, when the streamflow index was greater than or equal to 1.5 , all occurred after water year 1972 and ended with water years 1975-76, 1986-89, 1995-96, 1999-2001, and 2010-11. The driest 4-year periods when the streamflow index was less than or equal to -1.5 all occurred prior to water year 1973 and ended with water years 1940-41, 1954-57, and 1965-69.

In summary, the analysis of the annual and monthly time series for streamflow and recharge indicated an increase in the frequency and magnitude of wet periods, as defined by indices of streamflow and recharge, for the second onehalf of the simulation period (water years 1973-2014). This was generally consistent with the analysis of the annual time series for precipitation, which also indicated a shift from drier than average conditions for the early part of the simulation period to wetter than average conditions for the later part of the simulation period. The wettest 4-year periods in the simulation in terms of recharge and streamflow ended with water years 1975, 1987-88, and 2000-01, based on high index values of 1.7 and greater, and the driest 4-year periods in terms of recharge and streamflow ended with water years 1956-57 and 1966-67, based on low index values of less than approximately -2.0 .

\section{Mean Monthly Water Budgets}

The 100-year mean monthly results for simulated water-budget components, calculated for each month as the basinwide mean for the ONWM area, varied by month and season, mostly in response to the variations in mean monthly precipitation (fig. 54A). Inflows in the water budget are shown as positive values and included precipitation and negative storage changes. The negative storage changes were used to express the mean monthly results as a water balance, where the total inflow equals the total outflow for each month. Using negative storage changes, a decrease in storage is a positive value indicating an outflow of water from storage resulting in an equivalent inflow of water to the hydrologic system, and an increase in storage is a negative value indicating an inflow of water to storage resulting in an equivalent outflow of water from the hydrologic system. All outflows in the water budget are shown as negative values and include ET, streamflow, and groundwater losses. The mean monthly results for simulated streamflow indicate the equivalent basinwide mean depth of water discharged as streamflow from the ONWM area.

The distributions of mean monthly ET and streamflow were generally well correlated to the mean monthly distribution of precipitation, with a correlation coefficient of 0.94 calculated for ET and precipitation, and a correlation coefficient of 0.83 calculated for streamflow and precipitation. Mean monthly ET and streamflow were largest in May and June, which were also the months with the largest mean monthly precipitation of 4.8 and 4.9 inches, and smallest in January, which was also the month with the smallest mean monthly precipitation of 1.2 inches (figs. $54 A, B$ ). 


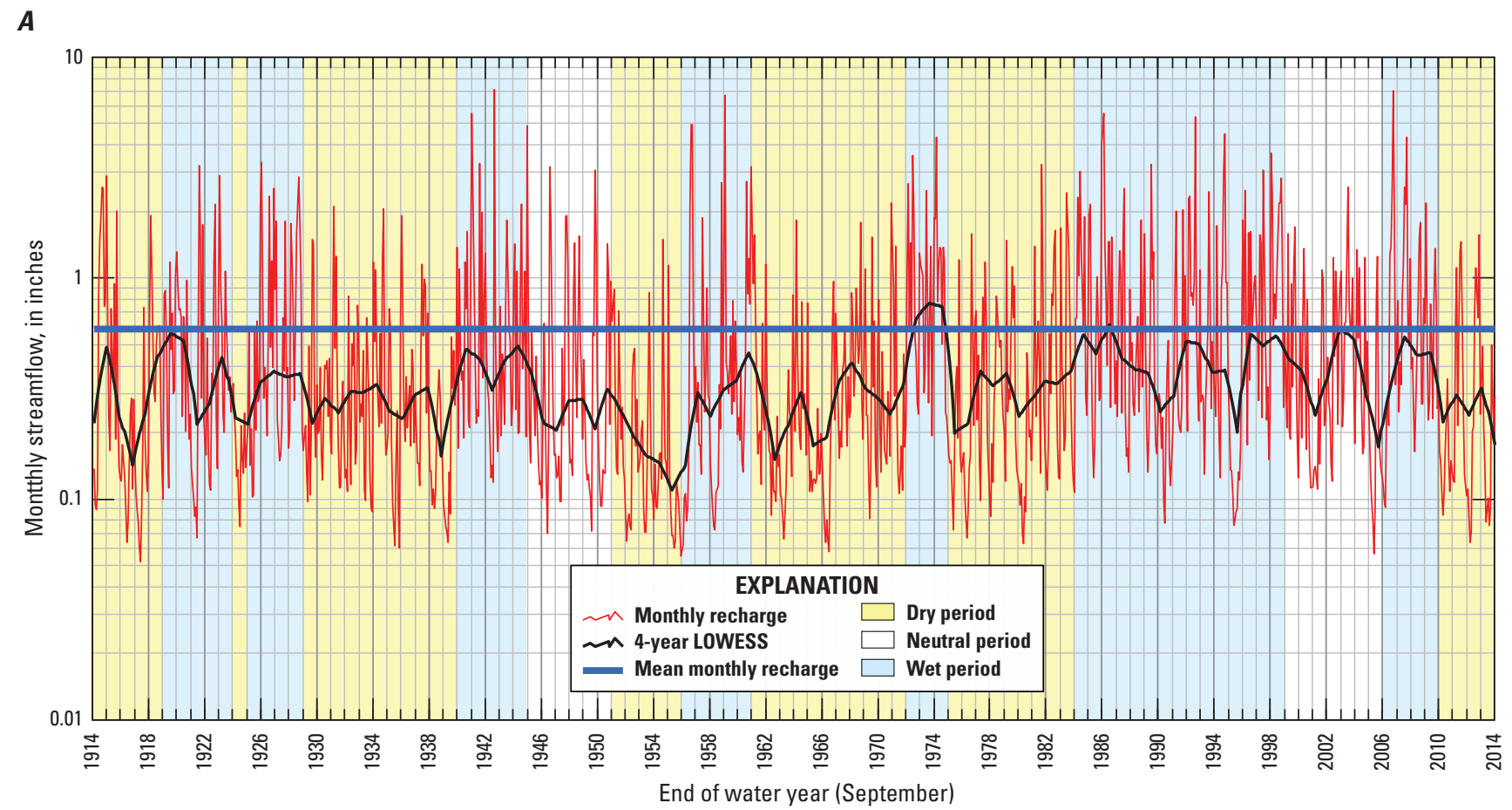

B

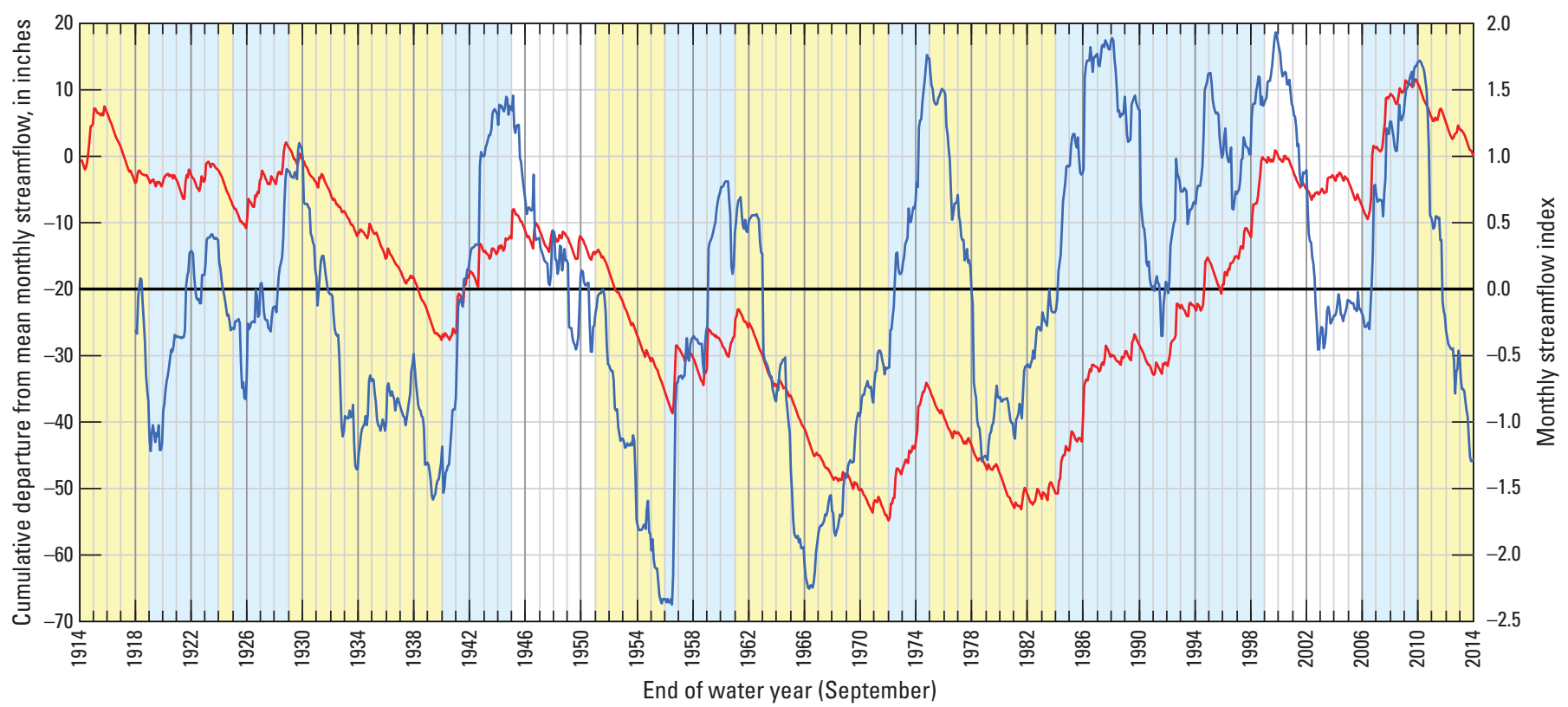

EXPLANATION

EXPLANATION
Zero line (monthly streamflow index)
Zn 4-year monthly streamflow index
m Cumulative departure from mean
monthly streamflow

Figure 53. Simulated monthly streamflow for water years 1915-2014 using the Osage Nation watershed model, Oklahoma and Kansas: $A$, monthly values and fitted 4-year LOWESS curve, and $B$, cumulative departure from 100-year mean monthly streamflow and 4-year monthly streamflow index. 
$\boldsymbol{A}$

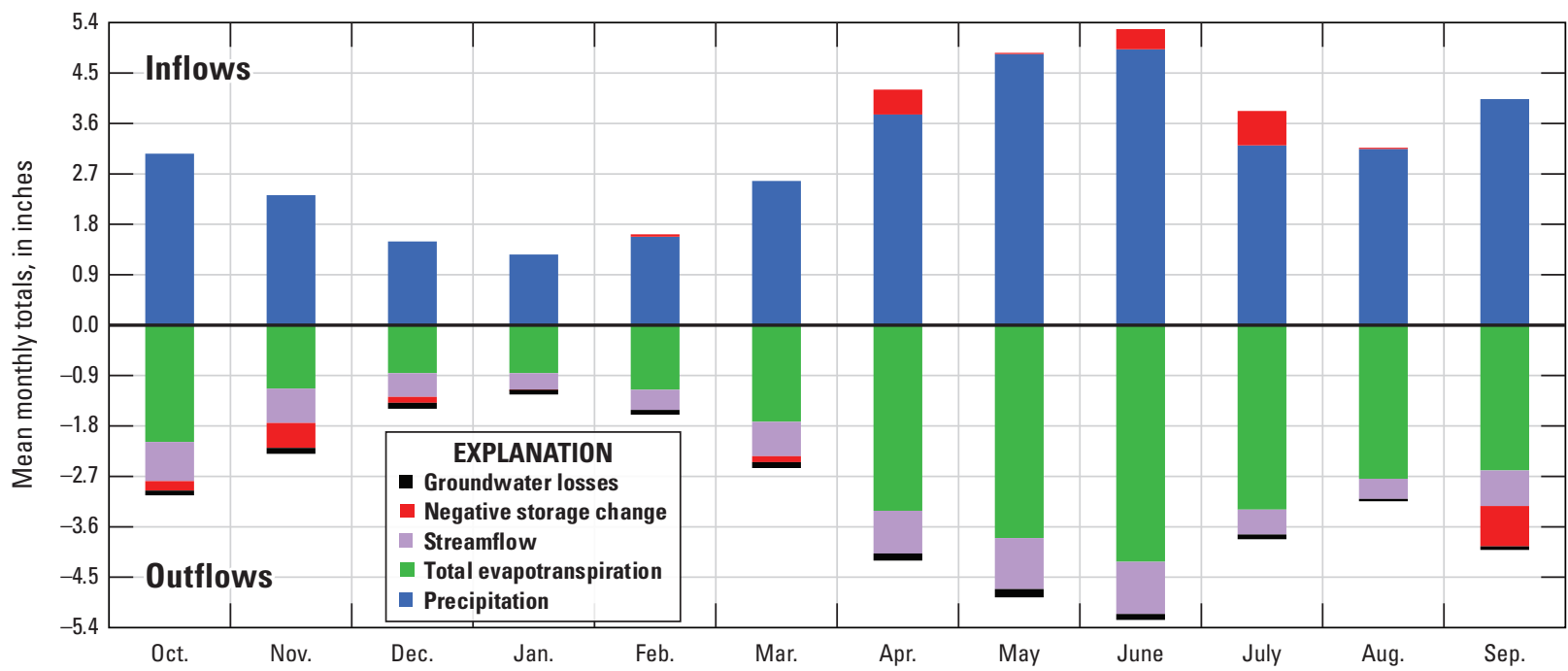

$B$

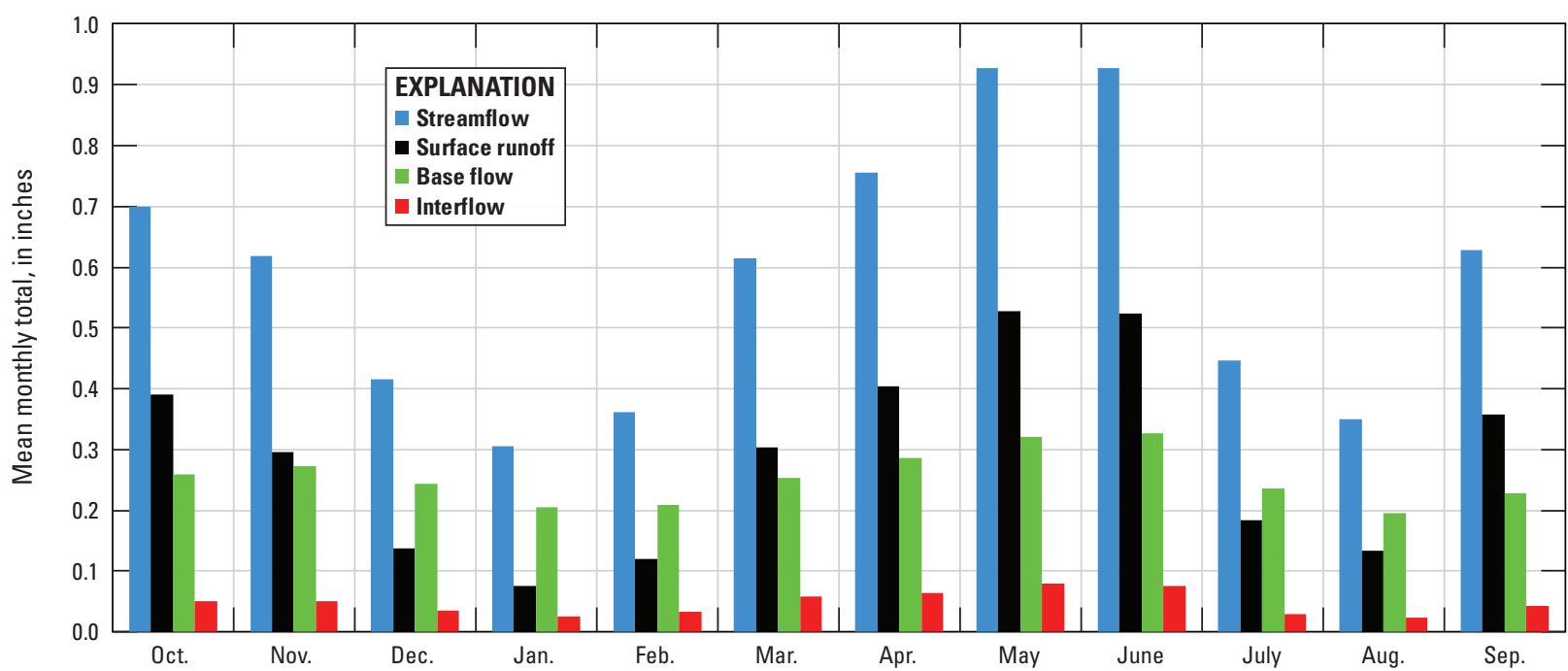

C

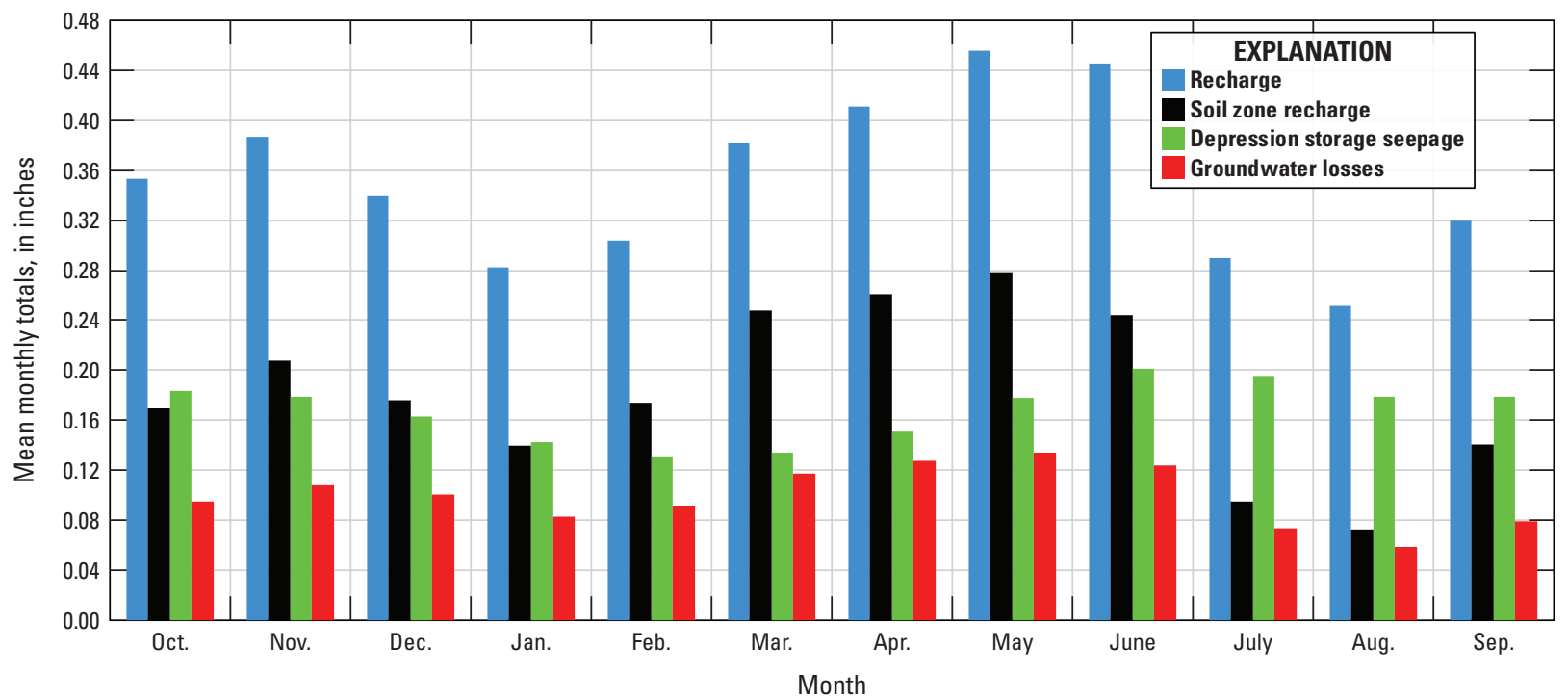

Figure 54. Mean monthly simulation results using the Osage Nation watershed model, Oklahoma and Kansas: $A$, water-budget inflows and outflows; $B$, components of streamflow; and $C$, components of recharge and groundwater losses. 
Evapotranspiration was the largest outflow from the ONWM area in all months, with a maximum mean monthly outflow of 4.2 inches in June, and the smallest outflows of 0.87 inch in December and 0.85 inch in January. Mean monthly PET was the largest in July at more than 7.4 inches (fig. 5), however, mean monthly ET of 3.8 inches in May was more than the 3.3 inches in July because mean monthly precipitation was 4.8 inches in May compared to 3.2 inches in July, and therefore more water was available for ET in May. Streamflow was the next largest outflow in all months except July and September, when changes in mean monthly water storage were larger than streamflow. As with ET, the largest mean monthly streamflow of 0.93 inch was in May and June, and the smallest streamflow of 0.31 inch was in January (fig. 54B). Unlike the mean monthly distribution for ET, the second smallest mean monthly streamflow of 0.35 inch was in August, the month with the sixth largest mean precipitation of 3.1 inches, because the large ET of more than 2.7 inches in the summer months resulted in drier soils which in-turn decreased the availability of water for streamflow.

Mean monthly outflows from groundwater losses were small compared to ET and streamflow for all months (figs. $54 \mathrm{~A}, \mathrm{C}$ ). Groundwater losses were at a minimum of 0.06 inch in August and a maximum of 0.13 inch in May. The maximum mean monthly outflow of water to storage (an increase in stored water) of 0.71 inch was in September as a result of drier soils at the end of August and more precipitation during September compared to August, and the maximum mean monthly inflow of water from storage (a decrease of stored water) of 0.63 inch was in July as a result of high ET combined with less precipitation compared to June. Absolute mean monthly storage changes were 0.04 inch or less for January, February, May, and August.

The components of streamflow simulated using the ONWM included surface runoff (Hortonian and Dunnian runoff), soil-zone interflow (fast and slow interflow), and base flow (groundwater discharge to streams). The mean monthly distributions of surface runoff, interflow, and base flow were similar, with maximum values in May and June, the wettest months on average, and minimum values in January and August (fig. 54B). The lower mean monthly values for streamflow in January was a result of January being the driest month on average, whereas the lower values for streamflow in August was a result of the high PET in August. The relative contributions to total streamflow from the three components of streamflow, however, was not the same for all months. Mean monthly surface runoff was 0.29 inch, about 49 percent of total streamflow on average, and was the largest component of streamflow for most months, ranging from to 0.08 inch in January, or about 25 percent of total January streamflow, to 0.53 inch in May, or about 57 percent of total May streamflow.
Mean monthly base flow was the second largest component of total streamflow, averaging 0.25 inch over all months, or about 43 percent of total streamflow, and ranging from a minimum of 0.20 inch in January, about 67 percent of total January streamflow, to a maximum of 0.33 inch in June, about 35 percent of total June streamflow. In general, surface runoff exceeded base flow during the wetter months (April through June and September through October), whereas base flow tended to exceed surface runoff during the relatively drier months following the wet periods (December through February and July through August). Mean monthly interflow was the smallest component of total streamflow for all months, averaging 0.05 inch for all months, about 8 percent of total streamflow, and ranging from 0.02 inch in August, about 6 percent of total August streamflow, to 0.08 inch in May, about 9 percent of total May streamflow.

Mean monthly recharge averaged 0.35 inch for all months, with a maximum of 0.46 inch in May, the second wettest month, and a minimum of 0.25 inch in August (fig. 54C). The maximum recharge was in May rather than June, the wettest month, because PET was higher in June than May, and ET used a larger fraction of available soil moisture in June. The minimum mean monthly recharge was in August rather than January, the driest month, because the higher ET in August used a larger fraction of the available soil moisture, leaving less water available for recharge. Soilzone recharge was the largest component of total recharge, averaging 0.18 inch for all months, or about 52 percent of total recharge. The distribution of mean monthly soil-zone recharge was similar to total recharge, with a maximum mean monthly value of 0.28 inch in May, about 61 percent of total recharge, and a minimum mean monthly value of 0.07 inch in August, about 29 percent of total recharge. In contrast, mean monthly depression seepage did not match the distribution of total monthly recharge, but rather was more similar to the distribution of mean monthly precipitation, with a minimum of 0.13 inch in February and March, the third and fifth driest months, and a maximum of 0.20 inch in June, the wettest month. Depression seepage exceeded mean monthly soil-zone recharge for five months (July through October and January). As a percentage of total recharge, the maximum of 71 percent was in August with a mean monthly depression seepage of 0.18 inch, and the minimum of 35 percent was in March. The distribution of mean monthly groundwater losses was similar to recharge. Mean monthly groundwater losses were less than soil-zone recharge and depression seepage for all months. As a percentage of recharge, mean monthly groundwater losses averaged 28 percent of total recharge for all months, and ranged from a minimum of 23 percent of total recharge in August to a maximum of 31 percent of total recharge in March and April. 
Total mean monthly water storage was smallest in August at about 3.4 inches and greatest in March at about 4.9 inches (fig. $55 \mathrm{~A}$ ). Total water storage was also greater in the months of December through March, at 4.8 inches or more, compared to other months. As with the seasonal distribution of total water storage, the mean monthly total subsurface-water storage reached a minimum value of 1.5 inches in August and a maximum value of 3.1 inches in March, mostly in response to the lower ET in the winter months that enabled an increase in soil moisture and the higher ET in late spring and summer causing drier soils in July through September. Subsurface mean monthly water storage was greater than surface water storage in the months of October through June, and averaged 2.5 inches for all months, or about 56 percent of total storage. In the months of July through September, mean monthly surface water storage was greater than subsurface storage because of higher ET during summer causing drier soils. In comparison to subsurface water storage, mean monthly surface water storage was less variable throughout the year, and was at a minimum in March of 1.8 inches and at a maximum in June of 2.1 inches.

The components of subsurface water storage simulated by the ONWM are the soil-zone reservoir and the groundwater reservoir, with the groundwater reservoir representing only the component of the groundwater-flow system directly contributing to base flow. The soil-zone reservoir includes water storage in the capillary reservoir, the gravity reservoir, and the preferential flow reservoir (fig. 18B). The capillary reservoir represents soil water storage less than or equal to field capacity and accounted for most of the water in the subsurface; the 100-year mean water content of the capillary reservoir was 2.0 inches, or 81 percent of total subsurface storage, with a minimum mean monthly water content of 1.2 inches in August and a maximum mean monthly water content of 2.6 inches in March (fig. 55B).

The gravity reservoir represents soil water storage greater than field capacity (excluding the preferential-flow reservoir representing macropore water storager) and accounted for the second largest component of water in the subsurfacet, with a 100 -year mean water content of $0.35 \mathrm{inch}$. The water content of the gravity reservoir was more sensitive to the monthly distribution of PET, with a minimum mean monthly water content of 0.22 inch in July, the month with the maximum PET, and a maximum mean monthly water content of 0.43 inch in November through January, the months with the lowest PET (figs. 5, 55B). The preferential-flow reservoir represents soil water storage in macropores (used in the ONWM for simulating fast interflow) and accounted for the smallest component of soil-zone water storage, with a 100 -year mean water content of 0.1 inch, a minimum mean monthly water content of about 0.05 inch in August and a maximum mean monthly water content of about 0.14 inch in April and May.

The groundwater reservoir accounted for the smallest component of total subsurface water storage. Groundwater in the ONWM conceptual model does not represent the total amount of water stored in the groundwater system underlying the ONWM area; it represents only the small fraction of groundwater stored along subsurface flow paths underlying the root-zone that contribute directly to base flow. The mean groundwater storage was 0.03 inch, about 1.3 percent of total mean subsurface water storage. The minimum mean monthly groundwater storage of 0.02 inch was in February, following the driest months (on average), and the maximum was about 0.04 inch in April through June, as a result of the higher recharge and seepage inflows during the wettest months (May and June) compared to other periods.

The components of surface storage simulated by the ONWM were snowpack, interception storage by vegetation, retention storage by impervious surfaces, and depression storage representing water bodies and stream channels. The 100 -year mean water content for total surface storage was 1.9 inches, with mean monthly depression storage accounting for 94 to 100 percent of total surface water storage. The 100 -year means for the remaining surface storage components were 0.02 inch for snowpack, 0.004 inch for interception storage, and $1.6 \mathrm{E}-5$ inch for retention storage. The minimum mean monthly values were 1.8 inches depression storage in February, zero snowpack storage in July through September, 0.002 inch interception storage in January, and zero retention storage in July and August. The maximum mean monthly values were 2.1 inches depression storage in June, 0.11 inch snowpack storage in January, 0.005 inch interception storage in May and June, and 7.1E-5 inch retention storage in January. 
$\boldsymbol{A}$

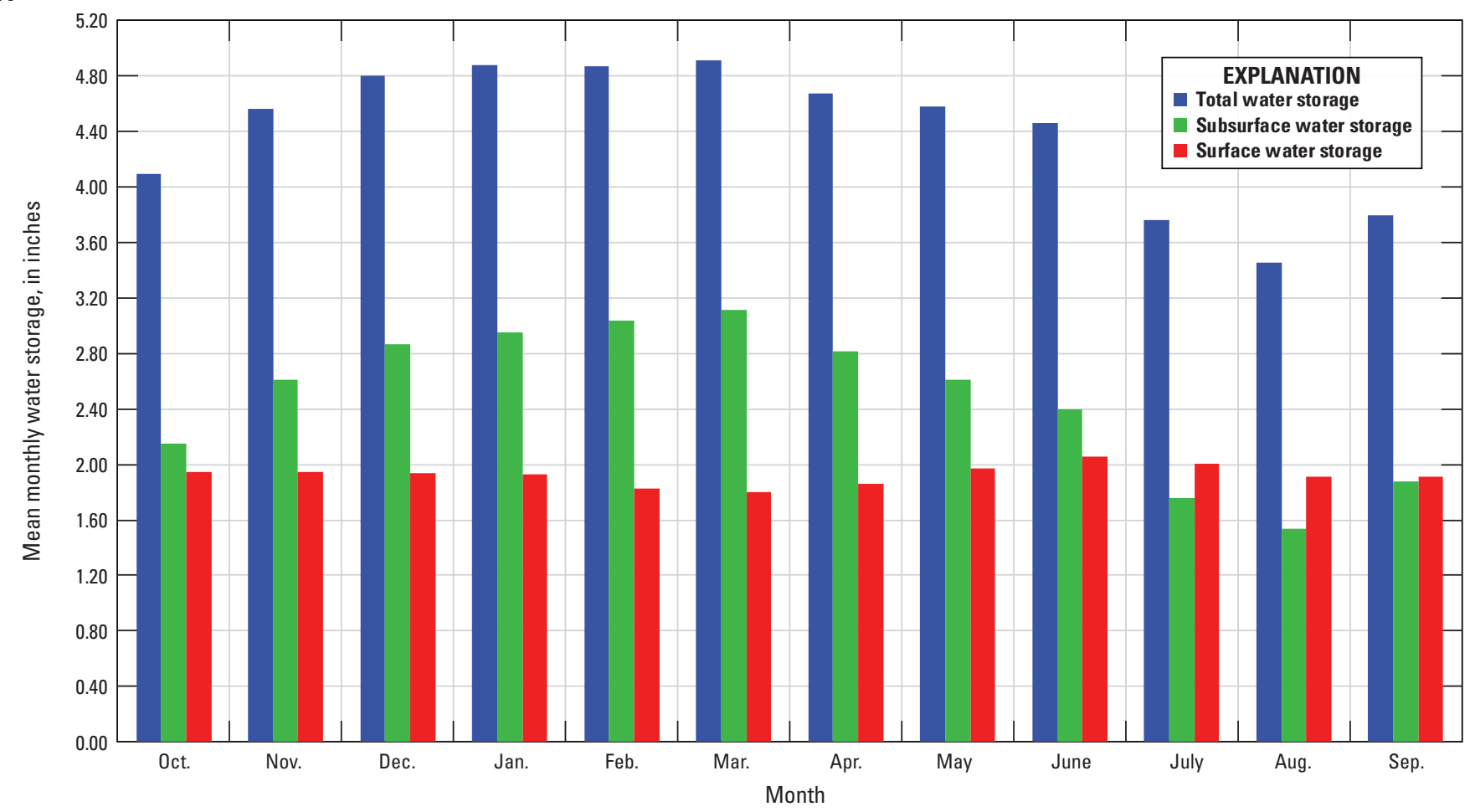

B

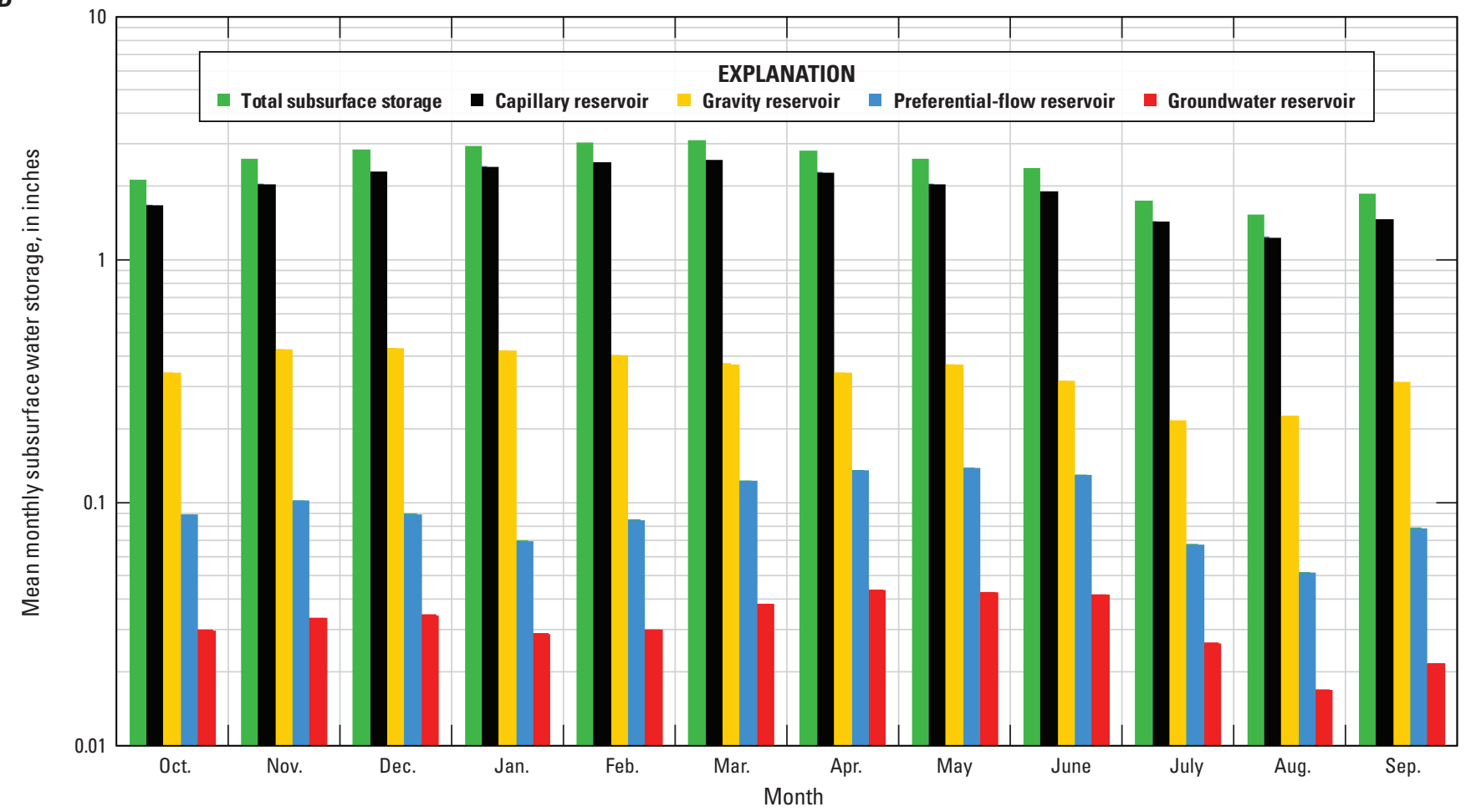

Figure 55. Mean monthly water contents for storage components, the Osage Nation watershed model, Oklahoma and Kansas: $A$, total water storage components, and $B$, subsurface water storage components. 


\section{Summary and Conclusions}

The U.S. Geological Survey (USGS) is cooperating with the Osage Nation on studies to evaluate the surface-water and groundwater resources of the Osage Nation, a 2,304-squaremile $\left(\mathrm{mi}^{2}\right)$ area of rolling pastures, tallgrass prairie, and mixed woodlands in northeastern Oklahoma. An important component of these studies is the development and application of a fully integrated surface-water and groundwater hydrologic model, the Osage Nation integrated hydrologic model (ONIHM). The ONIHM is needed for better quantification and understanding of the hydrologic system of the Osage Nation and to quantify the effects of historical and potential waterresource development for the Osage Nation.

This report describes the development and application of a daily precipitation-runoff model, the Osage Nation watershed model (ONWM), which is a necessary component of the ONIHM. The ONWM was developed using the USGS Precipitation Runoff Modeling System version-IV (PRMS-IV) computer software for an 8,343- $\mathrm{mi}^{2}$ study area in northeastern Oklahoma and southeastern Kansas centered on and including the Osage Nation and the ONIHM area (fig. 1). The ONWM is used as part of the ONIHM to directly couple spatially and temporally varying daily climate conditions affecting the ONIHM study area. As an integral part of the ONIHM, the ONWM simulates the inflow boundary conditions from tributary basins in the region outside of and surrounding the ONIHM area and provides an estimation of water budgets for the ONIHM area as well as the surrounding region, including tributary drainage basins outside of and next to the ONIHM.

The ONWM was used for a continuous daily simulation of the hydrologic system, with an emphasis on hydrologic processes of the land surface (including vegetation cover and impervious and pervious areas) and shallow subsurface defined by the upper soil layer and the root zone. The ONWM simulated potential evapotranspiration (PET); evapotranspiration (ET); snow hydrology; overland-flow processes; interflow processes in the soil zone; recharge; groundwater discharge and losses; and streamflow using hydrologic response units (HRUs), groundwater reservoirs, and stream segments. The spatial configuration and layout of HRUs, groundwater reservoirs, and stream segments defining the ONWM domain used a grid-based discretization with a grid-cell dimension of $1,312.3$ by $1,312.3$ feet ( 400 by 400 meters), resulting in a total of 135,044 HRUs and connected groundwater reservoirs, each with an area of 39.54 acres. The HRUs and groundwater reservoirs were connected by cascading flow paths to 7,389 linked stream segments representing the surface-water drainage network and the major stream channels in the ONWM area.

Daily climate inputs for the ONWM were developed using a modified inverse-distance-weighted spatial interpolation method, daily climate records from a regional network of 203 monitoring sites, and gridded Parameterelevation Regressions on Independent Slopes Model (PRISM) estimates of mean monthly precipitation and mean monthly maximum and minimum air temperatures. The geographic information system (GIS) data defining land use, land cover, soils, vegetation, and surficial geology were used as input for defining grid-cell parameters representing the physical characteristics of the ONWM area.

Calibration of the ONWM was done in four stages using available records of daily short-wave radiation (SWRAD) and potential evapotranspiration (PET) for 14 Oklahoma Climatological Survey Mesonet stations, soil moisture for 13 Mesonet stations, and streamflow records of daily mean streamflow for 22 USGS streamgages. Trial and error calibration was used to obtain a good fit between simulated and observed monthly values of SWRAD, PET, and soil moisture, and between simulated and observed daily, monthly, and annual mean values of streamflow. Calibration results indicated the greatest sensitivity to parameters controlling soil-zone water storage, overland flow, interflow, ET, recharge, and base flow. Model sensitivity to parameters controlling interception storage, groundwater losses, and additional parameters affecting interflow and recharge was moderate. Model sensitivity to the parameter controlling snowmelt infiltration was low. The calibration results for streamflow indicated a satisfactory overall fit to the record of daily flows at the 22 USGS streamgages and a good overall fit to the monthly and annual flows. Calibration results for daily streamflow indicated high model sensitivity to the use of Muskingum routing, as opposed to simple routing. This was true, in part, because traveltimes for streamflow over the regional scale of the ONWM area were generally greater than 1 day for many of the longer flow paths simulated by the ONWM. In addition, reservoir operations along the Arkansas River, the Caney River, and along tributaries of Bird Creek caused considerable dampening of peak daily flows during the larger storms, as well as an increase in low flows during the dry periods. In contrast to the daily flows, calibration results for monthly and annual flows were not sensitive to the method of daily streamflow routing (Muskingum or simple routing).

The ONWM was used to simulate the daily hydrologic water budget for a 100-year period beginning October 1, 1914, and ending September 30, 2014 (water years 1915-2014).

The simulation period was started October 1, 1909, to include a 5-year model initialization period prior to the start of the 100-year target period. The simulation results were used to develop and analyze the long-term, 100-year mean water budget as well as transient annual, monthly, and daily water budgets for 32 subbasins in the ONWM, including 16 subbasins in the ONIHM. 
The 100-year basin-wide mean results for the ONWM study area indicated that 27.9 inches per year (in/yr) (about 12.4 million acre-feet per year [acre-ft/yr]), or about 77 percent of the basin-wide precipitation of $36.1 \mathrm{in} / \mathrm{yr}$ (about $16.1 \mathrm{million}$ acre-ft/yr), was returned to the atmosphere by ET. About 7.1 in/yr (3.1 million acre-ft/yr), or 20 percent of precipitation in the ONWM area, was discharged as streamflow. Surface runoff (Hortonian and Dunnian combined) contributed 49 percent of the streamflow, whereas interflow through the soil zone contributed 8 percent and groundwater discharge (base flow) contributed 43 percent. The simulated 100 -year mean recharge was $4.2 \mathrm{in} / \mathrm{yr}$ (1.9 million acre-ft/yr), or about 12 percent of precipitation, of which recharge from soils, mostly in inter-channel areas, was $2.2 \mathrm{in} / \mathrm{yr}$, and downward percolation of water (seepage) from water bodies and major stream channels was $2.0 \mathrm{in} / \mathrm{yr}$. About $1.2 \mathrm{in} / \mathrm{yr}$ ( 0.5 million acre-ft/yr), or about 3 percent of precipitation, was simulated as groundwater losses or outflows that indirectly accounted for groundwater ET, pumping, and basin underflow.

Daily streamflow records for water years 1938-2014 from seven USGS streamgages were used to develop daily river inflows along the western boundary of the ONWM for five major river systems tributary to the ONWM area: (1) the Arkansas River, (2) the Cimarron River, (3) the Walnut River, (4) the Chikaskia River, and (5) the Salt Fork of the Arkansas River. The simulated 77-year mean streamflow from the ONWM area for water years 1938-2014, with the river inflows included, was about $10,570 \mathrm{ft}^{3} / \mathrm{s}$. The five river inflows contributed a total inflow of $6,106 \mathrm{ft}^{3} / \mathrm{s}$ to the ONWM, which more than doubled the total streamflow from the ONWM and more than tripled the streamflow for the Arkansas River in comparison to total streamflow from the ONWM for simulations that excluded the five river inflows.

The 77-year mean streamflow contributed from the ONWM area, simulated as the combined inflows to stream channels from Hortonian and Dunnian runoff, interflow, and base flow, was $4,468 \mathrm{ft}^{3} / \mathrm{s}$, including $2,445 \mathrm{ft}^{3} / \mathrm{s}$ streamflow contributed to the Arkansas River, $1,252 \mathrm{ft}^{3} / \mathrm{s}$ contributed to the Caney River, and $771 \mathrm{ft}^{3} / \mathrm{s}$ contributed to Bird Creek. The 77-year mean streamflow discharged from the ONIHM area was $7,420 \mathrm{ft}^{3} / \mathrm{s}$, including a combined mean inflow of $5,804 \mathrm{ft}^{3} / \mathrm{s}$ from nine upstream tributary subbasins and a mean streamflow of $1,616 \mathrm{ft}^{3} / \mathrm{s}$ contributed by the ONIHM area. A maximum daily mean streamflow of $191,700 \mathrm{ft}^{3} / \mathrm{s}$ was simulated for the Arkansas River at the outflow from the ONWM area. Maximum daily mean inflows to the ONIHM area included 126,500 $\mathrm{ft}^{3} / \mathrm{s}$ for the Kaw Lake-Arkansas River subbasin and $81,330 \mathrm{ft}^{3} / \mathrm{s}$ for the Salt Fork Arkansas River subbasin. Maximum daily mean streamflows simulated as outflows from the ONIHM area included $147,600 \mathrm{ft}^{3} / \mathrm{s}$ for the Arkansas River outflow from the Keystone Lake-Arkansas River subbasin and 40,670 $\mathrm{ft}^{3} / \mathrm{s}$ simulated for the Upper Caney River outflow. Maximum monthly mean streamflows simulated as inflows to the ONIHM area included $31,030 \mathrm{ft}^{3} / \mathrm{s}$ for the Kaw Lake-Arkansas River subbasin and 22,950 ft $3 / \mathrm{s}$ for the Salt Fork Arkansas River. Maximum monthly mean streamflows simulated as outflows from the ONIHM area included $62,040 \mathrm{ft}^{3} / \mathrm{s}$ simulated for the Keystone LakeArkansas River subbasin and 32,060 $\mathrm{ft}^{3} / \mathrm{s}$ for the Lower Beaver Creek subbasin.

The cumulative departure from the 100-year mean annual precipitation indicated a shift from drier than average to wetter than average conditions starting with about water year 1985, whereas the monthly time series for recharge and streamflow indicated a shift from drier than average to wetter than average conditions starting with water year 1973. The wettest 4-year periods in the simulation in terms of recharge and streamflow ended with water years 1975, 1987-88, and 2000-01, based on high index values of 1.7 and greater, and the driest 4-year periods in terms of recharge and streamflow ended with water years 1956-57, and 1966-67, based on low index values of less than approximately -2.0 .

The 100-year mean monthly results for precipitation, recharge, and streamflow indicated a bimodal distribution with March-June and September-November as the relatively wet periods and July-August and December-February as the relatively dry periods. Mean monthly precipitation, recharge, and streamflow were the greatest in May and June. On average, January was the driest month in terms of precipitation, whereas August, the sixth wettest month in terms of precipitation, had the least recharge and the second least streamflow as a result of higher ET and drier soils.

The results developed using the ONWM provided a spatially and temporally detailed quantification of the 100-year water budget for the Osage Nation and the area of interest for continued groundwater studies. The gridded HRU layout of the ONWM allowed for a more direct incorporation of spatially detailed data representing the physical characteristics of surface water drainages, including datasets for topography, hydrography, land cover, soils, and geology. In addition, the gridded HRU layout allowed for a higher-resolution representation of spatially distributed daily climate inputs (precipitation and maximum and minimum air temperature).

Simulation results using the ONWM indicated a high degree of localized spatial variability in soil moisture, ET, recharge, surface runoff, interflow, and base flow. The concentration of surface runoff and interflow along cascading flow paths, along with differences in slope, land cover, soil properties, and underlying geology, were more important in affecting the spatial distribution of recharge than the spatial distribution of precipitation and PET. The spatial variability in climate, including the increase in mean precipitation from west to east and differences in PET between north and south-facing slopes, did effect soil moisture, ET, recharge, surface runoff, and interflow; however, the local-scale spatial variability in land surface and shallow subsurface properties had a more pronounced effect on the spatial variability in the simulated water-budget components. Simulation results for subbasins and subbasin groups were more strongly correlated to regional-scale variations in precipitation and PET. 
Precipitation as snow showed a regional-scale correlation to air temperature; however, snow amounts were small compared to rainfall, and the water budget was not sensitive to snowfall and snowmelt processes over monthly and annual time steps.

In general, results using the ONWM indicated the importance of recharge as seepage from stream channels and water bodies to the overall hydrologic system. Water bodies represented by the ONWM using the PRMS depression storage module included ponds, streams, and larger lakes and reservoirs. Depression storage accounted for only about 2 percent of the ONWM area; however, the concentration of water from surface runoff and interflow into depressions resulted in 48 percent of the total recharge of $4.2 \mathrm{in} / \mathrm{yr}$ simulated as seepage from surface water stored in depressions. Most of the recharge, about 72 percent for the ONWM area, was discharged to major streams as the base-flow component of streamflow. The remaining 28 percent of recharge for the ONWM area was simulated as a groundwater loss or outflow. The basin-wide results for 32 subbasin areas within the ONWM indicated moderate variability between subbasins for precipitation (32.7 to $38.9 \mathrm{in} / \mathrm{yr}$ ), PET (48.3 to $54.1 \mathrm{in} / \mathrm{yr}$ ), and ET ( 24.4 to $30.0 \mathrm{in} / \mathrm{yr})$. More pronounced variability between subbasins was indicated for streamflow (3.5 to $13.3 \mathrm{in} / \mathrm{yr}$ ), recharge ( 0.9 to $8.6 \mathrm{in} / \mathrm{yr})$, surface water seepage contributions to recharge ( 0.2 to $6.6 \mathrm{in} / \mathrm{yr}$ ), and groundwater losses ( 0.07 to $2.7 \mathrm{in} / \mathrm{yr}$ ). The mapped results for the $135,055 \mathrm{HRUs}$ indicated a high degree of spatial variability between HRUs in simulated soil moisture, ET, streamflow (as cascading runoff, interflow, and base flow), and recharge. The high variability on the scale of the 39.54 acre HRUs was attributed to spatial variability in model parameters defined by GIS inputs (topograpy, land cover, soils, and geology) combined with the concentration of water routed along cascading flow paths connecting the HRUs to the major stream channels.

\section{References Cited}

Abbott, M.M., and DeHay, K., 2008, Aquifer tests and characterization of transmissivity, AdaVamoosa Aquifer on the Osage Reservation, Osage County, Oklahoma, 2006: U.S. Geological Survey Scientific Investigations Report 2008-5118, 10 p., https://doi.org/10.3133/sir20085118.

Andrews, W.J., and Smith, S.J., 2014, Description of landscape features, summary of existing hydrologic data, and identification of data gaps for the Osage Nation, northeastern Oklahoma, 1890-2012: U.S. Geological Survey Scientific Investigations Report 2014-5134, 53 p., https://doi.org/10.3133/sir20145134.

Beven, K.J., and Kirkby, M.J., 1979, A physically based, variable contributing area model of basin hydrology: Hydrological Sciences Bulletin, v. 24, no. 1, p. 43-69, https://doi.org/10.1080/02626667909491834.

Bingham, R.H., and Bergman, D.L., 1980, Reconnaissance of the water resources of the Enid quadrangle, north-central Oklahoma: Oklahoma Geological Survey, Hydrologic Atlas 7, 4 sheets, http://www.ou.edu/ogs/maps/hydrologicatlases.

Boyce, S.E., Hanson, R.T., Ferguson, I., Schmid, W., Henson, W., Reimann, T., Mehl, S.M., and Earll, M.M., 2020, One-Water Hydrologic Flow Model: A MODFLOW based conjunctive-use simulation software: U.S. Geological Survey Techniques and Methods 6-A60, 435 p., https://doi.org/10.3133/tm6A60. 
Bourlier, B.G., Nichols, J.D., Ringwald, W.J., Workman, P.J., and Clemmons, S., 1979, Soil survey of Osage County, Oklahoma: U.S. Department of Agriculture Soil Conservation Service, and U.S. Department of the Interior Bureau of Indian Affairs, 164 p., accessed January 12, 2014, at http:/www.nrcs.usda.gov/Internet/ FSE_MANUSCRIPTS/oklahoma/osageOK1979/ osageOK1979.pdf.

Cushman, R.C., 2004, Peterson Field Guides-The North American prairie: Boston, Mass., Houghton Mifflin Harcourt, 528 p.

Daly, C., Neilson, R.P., and Phillips, D.L., 1994, A statisticaltopographic model for mapping climatological precipitation over mountain terrain: Journal of Applied Meteorology, v. 33, no. 2, p. 140-158, https://doi.org/10.1175/15200450(1994)033\%3C0140:ASTMFM\%3E2.0.CO;2.

Daly, C., Gibson, W., Doggett, M., Smith, J., and Taylor, G., 2004, Up-to-date monthly climate maps for the conterminous United States: Proceedings of the 14th American Meteorological Society (AMS) Conference on Applied Climatology, 84th AMS Annual Meeting Combined Preprints, American Meteorological Society, Seattle, Washington, January 13-16, 2004, Paper P5.1, CD-ROM, 8 p., https://ams.confex.com/ams/84Annual/webprogram/ Paper71444.html.

Dickinson, J.E., Hanson, R.T., and Predmore, S.K., 2014, HydroClimATe-Hydrologic and climatic analysis toolkit: U.S. Geological Survey Techniques and Methods 4-A9, 49 p., https://doi.org/10.3133/tm4a9.

D’Lugosz, J.J., McClaflin, R.G., and Marcher, M.V., 1986, Geohydrology of the Vamoosa-Ada aquifer eastcentral Oklahoma with a section on chemical quality of water: Oklahoma Geological Survey Circular 87, 42 p., https://pubs.er.usgs.gov/publication/70046142.

Doherty, J., 2008, PEST-Model-independent parameter estimation, user manual (5th ed.): Brisbane, Australia, Watermark Numerical Computing, 336 p., https://www.nrc.gov/docs/ML0923/ML092360221.pdf.

Donigian, A.S., Jr., and Imhoff, J.C., 2009, Evaluation and performance assessment of watershed models: Proceedings of the Water Environment Federation, TMDL 2009, Alexandria, VA, WEF (Water Environment Federation), 30 p. https:/www.aquaterra.com/resources/pubs/pdf/ donigian-2009c.pdf.

Donigian, A.S., Jr., Imhoff, J.C., Bicknell, B.R., and Kittle, J.L., Jr., 1984, Application guide for hydrological simulation program-FORTRAN (HSPF):

Athens, Ga., U.S. Environmental Protection Agency, Environmental Research Laboratory, EPA-600/384-065, 177 p., https://nepis.epa.gov/Exe/ZyPURL. cgi? Dockey=2000HMKI.TXT.
Fenneman, N.M., and Johnson, D.W., 1946, Physical divisions of the conterminous United States: U.S. Geological Survey, 1 sheet, scale 1:7,000,000, https://water.usgs.gov/GIS/ metadata/usgswrd/XML/physio.xml.

Flint, A.L., and Flint, L.E., 2007, Application of the basin characterization model to estimate in-place recharge and runoff potential in the basin and range carbonaterock aquifer system, White Pine County, Nevada, and adjacent areas in Nevada and Utah: U.S. Geological Survey Scientific Investigations Report 2007-5099, 21 p., https://doi.org/10.3133/sir20075099.

Flint, L.E., and Martin, P., eds., 2012, with contributions by Brandt, J., Christensen, A.H., Flint, A.L., Flint, L.E., Hevesi, J.A., Jachens, R., Kulongoski, J.T., Martin, P., and Sneed, M., 2012, Geohydrology of Big Bear Valley, California: Phase 1-Geologic framework, recharge, and preliminary assessment of the source and age of groundwater: U.S. Geological Survey Scientific Investigations Report 2012-5100, 112 p., https://doi.org/10.3133/sir20125100.

Gesch, D., Evans, G., Mauck, J., Hutchinson, J., Carswell, W.J., Jr., 2009, The national map_Elevation: U.S. Geological Survey Fact Sheet 2009-3053, 4 p., accessed September 30, 2010, available at https://doi.org/10.3133/fs20093053.

Gurdak, J.J., Hanson, R.T., and Green, T.R., 2009, Effects of climate variability and change on groundwater resources of the United States: U.S. Geological Survey Fact Sheet 20093074, 4 p., available at https://doi.org/10.3133/fs20093074.

Hanson, R.T., Newhouse, M.W., and Dettinger, M.D., 2004, A methodology to assess relations between climate variability and variations in hydrologic time series in the southwestern United States: Journal of Hydrology, v. 287, nos. 1-4, p. 252-269, https://doi.org/10.1016/j.jhydrol.2003.10.006.

Hanson, R.T., Dettinger, M.D., and Newhouse, M.W., 2006, Relations between climate variability and hydrologic time series from four alluvial basins across the southwestern United States: Hydrogeology Journal, v. 14, no. 7, p. 11221146, https://doi.org/10.1007/s10040-006-0067-7.

Hanson, R.T., Boyce, S.E., Schmid, W., Hughes, J.D., Mehl, S.M., Leake, S.A., Maddock, T., III, and Niswonger, R.G., 2014, One-water hydrologic flow model (MODFLOW-OWHM): U.S. Geological Survey Techniques and Methods 6-A51, 120 p., https://doi.org/10.3133/tm6A51.

Heran, W.D., Green, G.N., and Stoeser, D.B., 2003, A digital geologic map database for the State of Oklahoma, U.S. Geological Survey Open-File Report 2003-247, 10 p., https://doi.org/10.3133/ofr03247. 
Hevesi, J.A., and Christensen, A.H., 2015, Estimating natural recharge in San Gorgonio Pass watersheds, California, 1913-2012: U.S. Geological Survey Scientific Investigations Report 2015-5122, 74 p., https://doi.org/10.3133/sir20155122.

Hevesi, J.A., Flint, A.L., and Flint, L.E., 2003, Simulation of net infiltration and potential recharge using a distributedparameter watershed model of the Death Valley region, Nevada and California: U.S. Geological Survey WaterResources Investigations Report 2003-4090, 171 p., available at https://doi.org/10.3133/wri034090.

Hevesi, J.A., Flint, L.E., Church, C.D., and Mendez, G.O., 2011a, Application of a watershed model (HSPF) for evaluating sources and transport of pathogen indicators in the Chino Basin drainage area, San Bernardino County, California: U.S. Geological Survey Scientific Investigations Report 2009-5219, 146 p., available at https://doi.org/10.3133/sir20095219.

Hevesi, J.A., Woolfenden, L.R., Niswonger, R.G., Regan, R.S., and Nishikawa, T., 2011b, Decoupled application of the integrated hydrologic model, GSFLOW, to estimate agricultural irrigation in the Santa Rosa Plain, California: Proceeding os the conference MODFLOW and More 2011-Integrated Hydrologic Modeling, Golden, Colorado, June 5-8, 2011, p. 115-119, https://pubs.er.usgs.gov/publication/70158990.

Hill, M.C., 1998, Methods and guidelines for effective model calibration; with application to UCODE, a computer code for universal inverse modeling, and MODFLOWP, a computer code for inverse modeling with MODFLOW: U.S. Geological Survey Water-Resources Investigations Report 98-4005, 90 p., https://doi.org/10.3133/wri984005.

Hirsch, R.M., 1982, A comparison of four streamflow record extension techniques: Water Resources Research, v. 18, no. 4, p. 1081-1088, https://doi.org/10.1029/WR018i004p01081.

Homer, C., Dewitz, J., Yang, L., Jin, S., Danielson, P., Xian, G., Coulston, J., Herold, N., Wickham, J. and Megown, K., 2015, Completion of the 2011 national land cover database for the conterminous United States-Representing a decade of land cover change information: Photogrammetric Engineering and Remote Sensing, Bethesda, MD, v. 81, p. 345-354, https://cfpub.epa.gov/si/si_public_record_ report.cfm?Lab=NERL\&dirEntryId=309950.

Hudson, M.R., Smith, D.V., Pantea, M.P., and Becker, C.J., 2016, Geologic and geophysical models for Osage County, Oklahoma, and implications for groundwater resources: U.S. Geological Survey Scientific Investigations Report 2016-5067, 27 p., https://doi.org/10.3133/sir20165067.
Hunt, A.M., and García, A.M., 2014, Simulation of natural flows in major river basins in Alabama: U.S. Geological Survey Scientific Investigations Report 2014-5021, 32 p., https://doi.org/10.3133/sir20145021.

Illston, B.G., Basara, J.B., Fisher, D.K., Elliott, R., Fiebrich, C.A., Crawford, K.C., Humes, K., and Hunt, E., 2007, Mesoscale monitoring of soil moisture across a statewide network: Journal of Atmospheric and Oceanic Technology, v. 25, p. 167-182, https://doi.org/10.1175/2007JTECHA993.1.

Jeton, A.E., 1999, Precipitation-runoff simulations for the Lake Tahoe Basin, California and Nevada: U.S. Geological Survey Water-Resources Investigations Report 99-4110, 61 p., https://doi.org/10.3133/wri994110.

Jeton, A.E., and Maurer, D.K., 2011, Precipitation and runoff simulations of select perennial and ephemeral watersheds in the middle Carson River Basin, Eagle, Dayton, and Churchill Valleys, west-central Nevada: U.S. Geological Survey Scientific Investigations Report 2011-5066, 44 p., https://doi.org/10.3133/sir20115066.

Koczot, K.M., Jeton, A.E., McGurk, B., and Dettinger, M.D., 2005, Precipitation-runoff processes in the Feather River Basin, northeastern California, and streamflow predictability, water years 1971-97: U.S. Geological Survey Scientific Investigations Report 2004-5202, 82 p., https://doi.org/10.3133/sir20045202.

LaFontaine, J.H., Hay, L.E., Viger, R.J., Markstrom, S.L., Regan, R.S., Elliott, C.M., and Jones, J.W., 2013, Application of the precipitation-runoff modeling system (PRMS) in the Apalachicola-Chattahoochee-Flint River Basin in the southeastern United States: U.S. Geological Survey Scientific Investigations Report 2013-5162, 118 p., https://doi.org/10.3133/sir20135162.

Leavesley, G.H., Lichty, R.W., Troutman, B.M., and Saindon, L.G., 1983, Precipitation-runoff modeling system-User's manual: U.S. Geological Survey WaterResources Investigations Report 83-4238, 207 p., https://doi.org/10.3133/wri834238.

Madsen, J., and Oberle, F., 1993, Tallgrass prairie: Kingwood, Tx., Falcon Press Publishing Company, 112 p.

Maidment, D.R., ed., 2002, Arc Hydro: GIS for Water Resources: Redlands, Calif., ESRI Press, 220 p.

Markstrom, S.L., Niswonger, R.G., Regan, R.S., Prudic, D.E., and Barlow, P.M., 2008, GSFLOW-Coupled ground-water and surface-water flow model based on the integration of the precipitation-runoff modeling system (PRMS) and the modular ground-water flow model (MODFLOW-2005): U.S. Geological Survey Techniques and Methods 6-D1, 240 p., https://doi.org/10.3133/tm6D1. 
Markstrom, S.L., Regan, R.S., Hay, L.E., Viger, R.J., Webb, R.M.T., Payn, R.A., and LaFontaine, J.H., 2015, PRMS-IV, the precipitation-runoff modeling system, version 4: U.S. Geological Survey Techniques and Methods 6-B7, 158 p., https://doi.org/10.3133/tm6B7.

McKay, L., Bondelid, T., Dewald, T., Johnston, J., Moore, R., and Rea, A., 2012, NHDPlus version 2-User Guide: 181 p., available at https:/nctc.fws.gov/courses/references/ tutorials/geospatial/CSP7306/Readings/NHDPlusV2_User_ Guide.pdf.

Nash, J.E., and Sutcliffe, J.V., 1970, River flow forecasting through conceptual models part I-A discussion of principals: Journal of Hydrology, v. 10, no. 3, p. 282-290, https://doi.org/10.1016/0022-1694(70)90255-6.

Oklahoma Climatological Survey, 2013, The climate of Osage County: Oklahoma Climatological Survey, 8 p., accessed August 8, 2013, at http://climate.ok.gov/county_climate/ Products/County_Climatologies/county_climate_osage.pdf.

Omernik, J.M., 1987, Ecoregions of the conterminous United States: Annals of the Association of American Geographers, v. 77, no. 1, p. 118-125, https://doi.org/10.1111/j.1467-8306.1987.tb00149.x.

Rewis, D.L., Christensen, A.H., Matti, J., Hevesi, J.A., Nishikawa, T., and Martin, P., 2006, Geology, ground-water hydrology, geochemistry, and ground-water simulation of the Beaumont and Banning storage units, San Gorgonio Pass area, Riverside County, California: U.S. Geological Survey Scientific Investigations Report 2006-5026, 191 p., https://doi.org/10.3133/sir20065026.

Ross, J.A., 1991, Geologic map of Kansas: Kansas Geological Survey, University of Kansas, Map M-23, scale 1:500,000.

Schlesinger, M.E., and Ramankutty, N., 1994, An oscillation in the global climate system of period 65-70 years: Nature, v. 367, p. 723-726, https://doi.org/10.1038/367723a0.
Seaber, P.R., Kapinos, F.P., and Knapp, G.L., 1987, Hydrologic unit maps: U.S. Geological Survey Water Supply Paper 2294, 63 p., https://doi.org/10.3133/wsp2294.

Shields, R.H., Jr., 1993, A water resources management strategy for surface and groundwater in Osage County, Oklahoma utilized to formulate policy guidelines for water rights and resources protection and management for Indian lands: Oklahoma State University, Ph.D. dissertation, 161 p.

Shukla, S., and Wood, A.W., 2008, Use of a standardized runoff index for characterizing hydrologic drought: Geophysical Research Letters, v. 35, no. 2, 7 p., available at https://doi.org/10.1029/2007GL032487.

U.S. Geological Survey, 2011, National land cover digital data: U.S. Geological Survey, available at https://www.mrlc.gov/data.

U.S. Geological Survey, 2016, National elevation dataset (NED) 1 arc-second downloadable data collection from the national map 3D elevation program (3DEP)national geospatial data asset (NGDA) national elevation data set (NED): U.S. Geological Survey, available at https://data.globalchange.gov/dataset/usgs-nationalelevation-dataset-ned-1-arc-second.

Ward-Garrison, C., Markstrom, S.L., and Hay, L.E., 2009, Downsizer - A graphical user interface-based application for browsing, acquiring, and formatting timeseries data for hydrologic modeling: U.S. Geological Survey Open-File Report 2009-1166, 27 p., https://doi.org/10.3133/ofr20091166.

Woolfenden, L.R., and Nishikawa, T., eds., 2014, Simulation of groundwater and surface-water resources of the Santa Rosa Plain watershed, Sonoma County, California: U.S. Geological Survey Scientific Investigations Report 2014-5052, 258 p., https://doi.org/10.3133/sir20145052. 
For more information concerning the research in this report, contact the Director, California Water Science Center U.S. Geological Survey 6000 J Street, Placer Hall Sacramento, California 95819 https://ca.water.usgs.gov

Publishing support provided by the U.S. Geological Survey Science Publishing Network, Sacramento Publishing Service Center 
